\title{
Fecapentaenes and risk for colorectal cancer
}

Citation for published version (APA):

de Kok, T. M. C. M. (1992). Fecapentaenes and risk for colorectal cancer. [Doctoral Thesis, Maastricht University]. Datawyse / Universitaire Pers Maastricht. https://doi.org/10.26481/dis.19921218tk

Document status and date:

Published: 01/01/1992

DOI:

10.26481/dis.19921218tk

Document Version:

Publisher's PDF, also known as Version of record

\section{Please check the document version of this publication:}

- A submitted manuscript is the version of the article upon submission and before peer-review. There can be important differences between the submitted version and the official published version of record.

People interested in the research are advised to contact the author for the final version of the publication, or visit the DOI to the publisher's website.

- The final author version and the galley proof are versions of the publication after peer review.

- The final published version features the final layout of the paper including the volume, issue and page numbers.

Link to publication

\footnotetext{
General rights rights.

- You may freely distribute the URL identifying the publication in the public portal. please follow below link for the End User Agreement:

www.umlib.nl/taverne-license

Take down policy

If you believe that this document breaches copyright please contact us at:

repository@maastrichtuniversity.nl

providing details and we will investigate your claim.
}

Copyright and moral rights for the publications made accessible in the public portal are retained by the authors and/or other copyright owners and it is a condition of accessing publications that users recognise and abide by the legal requirements associated with these

- Users may download and print one copy of any publication from the public portal for the purpose of private study or research.

- You may not further distribute the material or use it for any profit-making activity or commercial gain

If the publication is distributed under the terms of Article $25 \mathrm{fa}$ of the Dutch Copyright Act, indicated by the "Taverne" license above, 


\section{Fecapentaenes and risk for colorectal cancer}




\title{
Fecapentaenes and risk for colorectal cancer
}

\author{
PROEFSCHRIFT
}

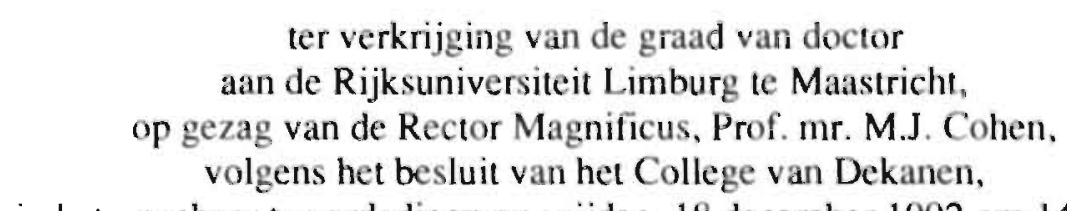

in het openbaar te verdedigen op vrijdag, 18 december 1992 om 14.00 uur

door

Theodorus Martinus Cornelis Maria de Kok

geboren te Goirle op 21 februari 1963

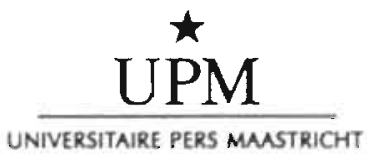




$\begin{array}{ll}\text { Promotores: } & \text { Prof. dr. F. ten Hoor } \\ & \text { Prof. dr. J.C.S. Kleinjans } \\ & \\ \text { Beoordelingscommissie: } & \text { Prof. dr. W.H.M. Saris (voorzitter) } \\ & \text { Prof. dr. G.H. Blijham (Rijksuniversiteit Utrecht) } \\ & \text { Prof. dr. L. den Engelse (Rijksuniversiteit Leiden) } \\ & \text { Prof. dr. F.C.S. Ramaekers } \\ & \text { Dr. H.H.W. Thijssen }\end{array}$

CIP-GEGEVENS KONINKLIJKE BIBLIOTHEI:K, DEN HAAG

Kok, Theodorus Martinus Cornelis M:ria de

Fecapentaenes and risk for colorectal cancer Theodorus Martinus Comelis Maria de Kok Matastrichı Universitaire pers Maissricht. -11l Thesis Maastricht. - With ref. - With summary in Dutch. ISBN 90-5278-050-1

Subject headings: fecapentaenes/ colorectal-cancer/genotoxicity

Ontwerp onslag: Datawyse Maastricht

Aquarel: $\quad$ Theo de Kok

Druk: Datawyse Mastricht

Het verschijnen van dit proefschrift en het onderzoek beschreven in hoofdstuk 5 werd mede mogelijk gemakkt door financiële steun van de Stichting Dr. Jr. J.H.J. van de Laar, de Jan Dekkerstichting \& dr. Ludgardine Bouwmanstichting en de Faculteit der Gezondheidswetenschappen, Rijksuniversiteit Limburg. 
Aan mijn ouders:

Voor I'rudy en Marloes 


\section{Contents}

page

$\begin{array}{ll}\text { Abbreviations } & 8\end{array}$

Chapter 1: General introduction 11

1.1. Search for etiological factors in colorectal carcinogenesis: 11

- Epidemiological aspects of colorectal carcinogenesis 11

- Colorectal cancer, a multistage process $\quad 12$

- Fecal mutagenicity 14

I.2. Discovery and identification of the fecapentaenes $\quad 15$

1.3. Genotoxicity of fecapentaenes: 18

- In vitro genotoxicily 18

- In vivo genotoxicity 20

- Molecular and genotoxic mechanisms 20

1.4. Epidemiological aspects of fecapentaene excretion: 23

- fecapentaene quantification and occurrence in human 23 populations

- dietary effects on fecapentaene excretion 24

- fecapentaene excretion in relation to colorectal cancer. 25

1.5. Outline of the thesis $\quad 25$

Chapter 2: Quantitative analysis and identification of eight naturally $\quad 37$ occurring fecapentaene analogues in human feces by high performance liquid chromatography.

Appendix: Further studies on the identification of naturally occurring fecapentaene analogues as well as other fecaenes in human feces.

Chapter 3: Excretion of different fecapetnaene analogues and fecal mutagenicity in relation to nutrient intake and fecal parameters in humans on omnivorous and vegetarian diets.

Chapter 4: Effects of fecal composition on fecapentaene kinetics in the large bowel: a new hypothesis.

Chapter 5: Case-control study on fecapentaene excretion and adenomatous polyps in colon and rectum.

Chapter 6: Detcction of oxygen radicals generated by fecapentaene-12 using electron spin resonance spectroscopy and reduction of fecapentaene mutagenicity to Salmonella typhimurium by hydroxyl radical scavenging. 
Chapter 7: Induction of oxidative damage to 2'-deoxyguanosine, isolated and cellular DNA, and effects on the biological activity of single stranded $\Phi \mathrm{XX}-174$ DNA by synthetic fecapentaene- 12 .

Chapter 8: General discussion.

1.1. Fecapentaene exposure as possible risk factor for colorectal cancer.

1.2. Epidemiological aspects of fecapentaene excretion.

- Analysis of fecapentaene excretion and fecal mutagenicity 132

- Fecapentaene excretion in groups at different risk for colorectal cancer

- Fecapentaene excretion in relation to nutrient intake 134

- Kinetic aspects of fecapentaene excretion 136

1.3. Mechanism of fecapentaene genotoxicity.

- Oxygen radical formation by FP-12 and induction of oxidative and alkylating DNA damage

- Fecapentaene genotoxicity and measurement of biological effects

1.4. General conclusion.

Summary

Samenvatting

Dankwoord

List of co-authors

List of publications 


\section{Abbreviations}

Fecapentaene nomenclature:

FP-12

FP- 14

$\mathrm{FP}(\mathrm{xx})$

Fecapentaene-12

Fecapentaene-14

FP followed by numbers in parentheses indicate chromatographic retention times of different fecapentaene analogues under analytical conditions described in Chapter 2.

Total FP-12: sum of FP(13.2), FP(13.5) and FP(14.0)

Total FP-14: sum of FP(17.7) and FP(18.2)

\begin{tabular}{|c|c|}
\hline $\mathrm{BHT}$ & butylated hydroxytoluene \\
\hline $\mathrm{COOH}$ & cumene hydroperoxide \\
\hline $\mathrm{dG}$ & 2 -deoxyguanosine \\
\hline DMPO & 5,5 dimethyl-1-pyrroline $\mathrm{N}$-oxide \\
\hline DMSO & dimethylsulfoxide \\
\hline$d N p ' s$ & deoxynucleotide 3'monophosphates \\
\hline $\mathrm{ds}$ & double stranded \\
\hline DTPA & diethylenetriaminepentaacetic acid \\
\hline $\mathrm{ECD}$ & electro chemical detection \\
\hline ESR & electron spin resonance spectroscopy \\
\hline $\mathrm{HP}$ & hydrogen peroxide \\
\hline hprt & hypoxanthine guanine phosphoribosyltransferase \\
\hline ip & intraperitoneal \\
\hline GSH & glutathione \\
\hline GSSG & oxidized glutathione \\
\hline HPLC & high prerformance liquid chromatography \\
\hline LO & lipoxidase \\
\hline LSD & least significant difference \\
\hline ns & not significant \\
\hline $8-o x o d G$ & 2'-deoxy-7,8-dihydro-8-oxoguanosine \\
\hline PHS & prostaglandin $\mathrm{H}$ synthase \\
\hline POBN & $\alpha$-(4-pyridyl-1-oxide)-N-t-butylnitrone \\
\hline $\mathrm{p} / \mathrm{s}$ ratio & polyunsaturated-to-saturated fatty acid ratio \\
\hline RT & retention time. \\
\hline SA & sodium azide \\
\hline sc & subcutaneously \\
\hline SCE & sister chromatid exchange \\
\hline SS & single stranded \\
\hline
\end{tabular}


SSB single strand breaks

SOD superoxide dismutase

tBA tert-butyl alcohol

$\mathrm{TBOOH}$ tert-butyl hydroperoxide

TEA tri-ethylamine

TMP 2,2,6,6-tetramethylpiperidine

TEMPO 2,2,6,6-tetramethylpiperidine- $\mathrm{N}$-oxide

U units

UDS unscheduled DNA Synthesis 



\section{Chapter 1}

\section{General introduction}

\subsection{Search for etiological factors in colorectal carcinogenesis}

\section{Epidemiological aspects of colorectal carcinogenesis}

Colorectal cancer appears to be a common disease of Western civilization. High incidences are found in North America, Western Europe and Australia, whereas cancer of the large bowel is relatively rare in Africa, Asia and South and Central America (1-4). For instance, every year approximately 145,000 and 7250 new cases of colorectal cancer occur in the United States and The Netherlands respectively $(4,5)$. Results from epidemiological studies have demonstrated that environmental rather than genetic factors determine the risk of colorectal cancer in a population. For instance, migrants from countries with relatively low incidences of colorectal cancer have an increased risk for developing this disease similar to that in their current homeland, unless they strongly cling to their original national culture and lifestyle (1-7). This indicates that the environmental factors which may be involved should be subdivided in two groups, physical and cultural components. The physical environment includes geographic factors, air pollution, radiation, climate etc, all factors that are equal for all individuals of a certain population or community. Cultural environmental factors include dietary habits, smoking, physical activity, use of drugs and alcohol, which are more individually determined. Although the relevance of most of these factors is still under discussion (8-13), there is a general consensus that diet is important in the causation of the disease.

Epidemiological studies of the relationship between diet and the risk for colorectal cancer can be divided into three classes: population, case-control and cohort studies. Results from population studies, in which dietary data and cancer risk for a series of populations have been compared, virtually all show a correlation between colorectal cancer risk and dietary fat and meat (14-21). In some studies, also an inverse correlation is found with dietary fiber (18-22). The methodological advantage of case-control studies, in which the diet of individual colorectal cancer patients are compared with matched control persons, is that putative confounding factors can be eliminated by choice of the control group. However, dietary habits during the period before the occurrence of the first symptoms and final diagnosis are difficult to assess as a consequence of rather unreliable recall methods (1). Many of these studies, though not all, show results consistent with those obtained in the population studies $(8,9,11,12,23-26)$. Only a few cohort studies have been conducted $(27,28)$, supporting the general conclusion that colorectal cancer tends to be associated with a high intake of total energy, animal fat and meat, and with a 


\section{low intake of cereal fiber.}

Two major biological mechanisms have been proposed to explain the role of dietary fat and fiber in colon cancer etiology $(29,30)$. The first indicates the role of dietary fat in the production of bile acids, which have been shown potentially relevant in animal carcinogenesis (31-37). The second hypothesis was first proposed by Burkitt $(38,39)$ and suggests a protective role of fiber against colon cancer. High fiber diets may decrease transit time of carcinogens or tumor promoters, and thereby reduce contact time of colon mucosa. Further, fiber can affect the composition of the gut microflora or its detoxifying metabolic activity, as well as production, absorption and excretion of putative carcinogens (30).

The epidemiology of this disease and the relevance of specific dietary factors in colorectal carcinogenesis has been reviewed extensively $(1,29,40-44)$.

\section{Colorectal cancer, a multistage process}

Experimental studies in animal carcinogenicity models, such as the mouse skin carcinogenicity assay and hepatocarcinogenesis in the rat, have demonstrated that at least three stages can be distinguished within this process: initiation, promotion and progression (45-49). During the stage of initiation, inheritable modifications in the DNA are chemically induced which are considered to be irreversible. These DNA modifications include gene mutations and DNA rearrangements. In contrast to tumor initiation, promotion is suggested to be reversible and to result in the expansion of initiated cell clones. Unlike initiating agents, the dose response to promoting agents exhibits a threshold or no-effect level and a maximal response $(45,49,50)$. Further, it has been suggested that promoting effects are induced by activating of cellular protein kinase $\mathrm{C}$ (PKC). This results in a cascade of events which include alterations in the function of membrane-associated ion channels and receptors, alterations in gene expression and, ultimately, changes in cellular differentiation and proliferation (51). The third phase, progression, is characterized by cellular biochemical and karyotypic changes as well as increased growth rate, invasiveness and metastatic capability. Like initiation, progression appears to involve changes in the genome of the cell that are irreversible (52).

Mainly as a result of work by Vogelstein and coworkers, the genetic basis of colorectal tumorigenesis is, as compared to other malignities, relatively well understood (53-55). These authors presented a genetic model for colorectal neoplasia as shown in Figure 1, with the following predominant features. First, most if not all malignant colorectal tumors (carcinomas) arise from preexisting benign tumors (adenomas), as is demonstrated by numerous clinical and histopathological data (56). Second, colorectal tumors are induced by mutational activation of proto-oncogenes probably coupled with the mutational inactivation of tumor suppressor genes. Third, at least 4 to 5 gene mutations, including ras gen mutations and allelic deletions of $5 q, 17 p$ and $18 q$ are required for the formation of malignant tumors. Fewer mutations may lead to benign tumorigenesis. Fourth, tumor development is determined by the total accumulation of mutations rather than the order of induction, although they generally seem to follow a specific sequence. Apart from the essential role of initiators in this process, induction of cell division has been suggested to be almost as important (57). For instance, once the first copy of a tumor suppressor gene has been mutated, the inactivation of the second copy (loss of heterozygosity) is more likely to be caused by processes the frequency of which is dependent on cell division (mitotic recombination, gene 


\section{GENETIC MODEL FOR MUTISTAGE HUMAN COLORECTAL TUMORIGENESIS}

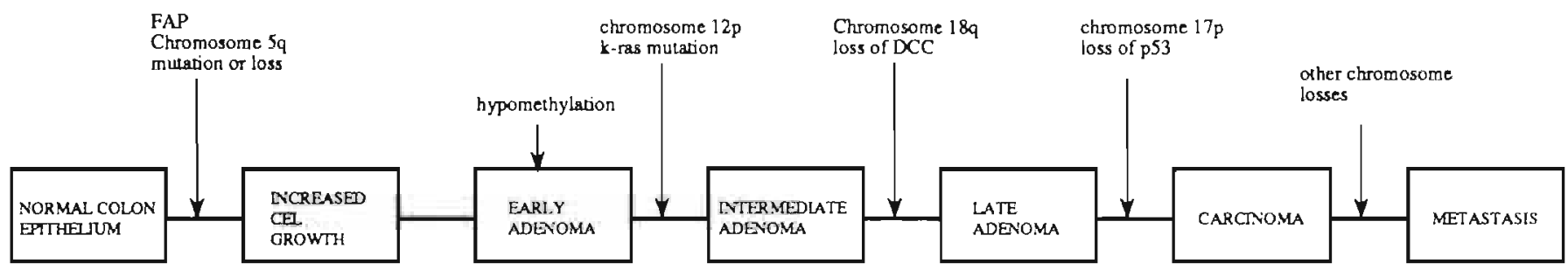

Fig. 1: Mutational events involving oncogenes ( $k$-ras) and tumor suppressor genes (on chromosome $5 q, 17 p$ and $18 q$ ). The three stages of adenomas generally represent tumors of increasing size, dysplasia and villous content. In patients with familial adenomatous polyposis (FAP), a mutation on chromosome $5 q$ is inherited. This alteration may be responsable for the proliferative epithelium present in these patients. In tumors arising in patients without polyposis, the same region may also be lost and/or mutated at relatively early stages of tumorigenesis. Hypomethylation has been found in small adenomas in patients with or without polyposis, and has been shown to inhibit chromosome condensation and subsequent mitotic nondisjunction. Therfore, epigenetic changes like hypomethylation could contribute to instability in the numor cell genome

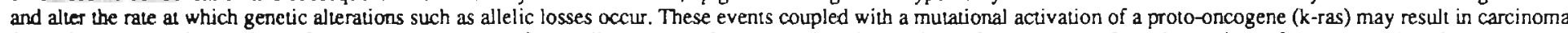
formation. The allelic deletions of chromosome $17 \mathrm{p}$ and $18 \mathrm{q}$ usually $\alpha c \mathrm{cur}$ at a later stage than do deletions of chromosome $5 \mathrm{q}$ and mutations of ras gene, although accumulation of these changes seems more important than their order with respect to one another.

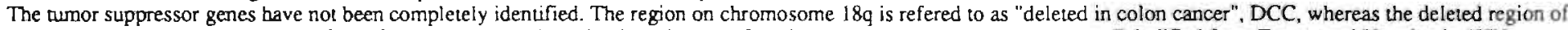
chromosome $17 \mathrm{p}$ contains the gene for $\mathrm{p} 53$, a phosphoprotein which is believed to function normally as a tumor suppressor. [Modified from Fearon and Vogelstein (55)]. 
conversion, and nondisjunction), than by an independent second mutation. Therefore, loss of heterozygosity will be stimulated by increased mitogenesis. Further, cell division increases mutagenesis due to: a) conversion of DNA adducts to mutations before they are repaired, b) mutations induced by replication, and c) increased susceptibility of replicating DNA to damage.

\section{Fecal mutagenicity}

It has been shown that risk for colorectal cancer is substantially determined by environmental factors such as the diet (see above). As human stool represents the endproduct of diet, digestive and excretory processes, as well as colonic bacterial metabolism, the examination of fecal contents has been suggested to provide the best available non-invasive way of studying exposures of the colorectal mucosa, including those that are of dietary origin. Stimulated by the finding of Bruce and coworkers (58) that human feces contain mutagenic compounds, DNA-modifying capacity of human fecal extracts has been studied using the Salmonella mutagenicity assay. The main studies for fecal mutagenicity are summarized in Table 1 , and have been reviewed and discussed previously (59-61). Fecal mutagenicity has been studied in relation to dietary habits, in populations at different risks for developing colorectal cancer and in case-control studies. In summary, correlational studies and dietary trials reveal associations between high risk of colorectal cancer and high fecal mutagenicity. Populations consuming "high risk" diets rich in animal fat and with low fiber content, appear to excrete more mutagenic feces as compared to "low risk" vegetarian diets. Further, some studies suggest that more than one mutagen may be present, and that mutagenicity may be influenced by presence of mutagenicity-inhibiting or co-mutagenic factors (76-82). The limited number of case-control studies with colorectal cancer patients and the study on patients with adenomatous polyps present no evidence for correlations between fecal mutagenicity and malign or benign tumorigenesis $(68,72,74-76)$.

The interpretation of fecal mutagenicity data in relation to colorectal tumorigenesis is hampered by several specific shortcomings and assumptions:

1. Each assay for assessing fecal genotoxicity is limited in its analytical potential, determined by extraction and purification procedures and experimental conditions.

2. Colorectal carcinogens may also reach putative target cells in the mucosal crypts via the blood stream.

3. In vitro expression of fecal genotoxicity may not accurately reflect the in vivo colorectal process, since the bowel presents a complex (an)aerobic ecosystem.

Therefore, it appears essential to identify the mutagens present in human stool. Until now, several classes of fecal mutagens have been identified:

1) Human colon may be exposed to pyrolysis products formed during food preparation, like benzo[a]pyrene and products of the Maillard reaction like furans and imidazoles (83-85). These types of compounds have been shown to be potent genotoxins $(84,86,87)$. 
2) Derivatives of cholesterol, 4 cholesten-3-one and 5 $\alpha$-cholestan-3-one, which are present in feces, were shown to induce chromosomal aberrations in murine colon epithelium (88). Both concentration of fecal 4-cholesten-3-one and the occurrence in colon biopsies of nuclear aberrations appear higher in patients with colorectal tumors as compared to controls (85).

3) Putative mutagens and carcinogens originating from the diet like flavonoids, lipid peroxidation and caramel browning products have been identified $(83,89)$.

4) The presence of bile acids, neutral steroids and long chain fatty acids in feces has also been related to colorectal malignity $(42,90-95)$. Secondary bile acids generated by metabolism of intestinal bacteria were shown to be comutagenic in microbial test systems $(31,32)$ and co-carcinogenic in various animal models (33-37). Using the fluctuation test, various bile acids were shown to possess a moderate mutagenic potential (96).

5) Finally, fecapentaenes have been indicated as putative initiators of colorectal carcinogenesis. This class of potent mutagens has been found to occur in feces of the majority of Western populations, and excreted concentrations may amount up to several $\mathrm{mg} / \mathrm{kg}$ wet feces $(81,97-101)$. Their presence in human feces was found to explain largely the fecal mutagenicity to Salmonella TA 100 without S9. Further, synthetic fecapentaene-12 (FP-12) reveals a remarkably high genotoxic potential in various mammalian cell types.

The importance of the fecapentaenes as well as of all other mentioned compounds in the origin of human colon cancer is still being discussed. Of the above mentioned features of the fecapentaenes, the pronounced genotoxic activity, the wide occurrence in human populations and high excretion levels, indicate the relevance to continue the study on microbial fecapentaene synthesis in the bowel, their fecal excretion as well as the mechanism of genotoxicity and the induction of genetic damage by this class of mutagens.

\subsection{Discovery and identification of the fecapentaenes}

In 1977, Bruce and coworkers first reported mutagenic activity of fecal extracts in the Ames mutagenicity assay (58). Initially, it was suggested that the mutagenic compound in fecal extracts was an $\mathrm{N}$-nitroso compound, but structure elucidation was hampered by extreme instability of the compound when exposed to light, oxygen or acidic conditions $(102,103)$. The compound was characterized by a specific UV absorbance spectrum with maxima at 320,340 and $365 \mathrm{~nm}$, which showed a downscale shift during decomposition $(102,104)$. In attempts to identify this major mutagenic compound in human feces, relatively large amounts of feces were extracted and purified on silica and preparative HPLC (105). The structure was essentially deduced by taking ' $\mathrm{H}$ NMR spectra of the isolated compounds. This analysis suggested the presence of a glycerol moiety, 1-substituted with an unsaturated ether. The length of the aliphatic chain was determined by HPLC interfaced with a mass spectrometer, showing for one compound the presence of a $\mathrm{C}_{12}$ unsaturated chain and for another a $\mathrm{C}_{14}$ chain. These two forms are referred to as FP-12 and fecapentaene-14 (FP-14) respectively (Figure 2) (105-109). Since 
Table I: Fecal mutagenicity in human populations.

\begin{tabular}{|c|c|c|c|c|}
\hline Reference & & $\begin{array}{l}\text { Research populations/ } \\
\text { Dietary variables }\end{array}$ & $\begin{array}{l}\text { Experimental conditions / } \\
\text { Salmonella strains }\end{array}$ & Main conclusions \\
\hline \multicolumn{5}{|l|}{ Dietary trigls: } \\
\hline de Vet 1981 & $(62)$ & $\begin{array}{l}\text { Dietary supplementation with } \\
\text { fried meat }\end{array}$ & $\begin{array}{l}\text { Ether extracts; TA } 98 \text { and } \\
\text { TA } 100 \pm \text { S } 9\end{array}$ & $\begin{array}{l}\text { No effect of fried meat supplementation } \\
\text { was found on fecal mutagenicity }\end{array}$ \\
\hline Díon 1982 & $(63)$ & $\begin{array}{l}\text { Dietary supplementation with } \\
\text { vitamin } \mathrm{C} \text { and } \mathrm{E}\end{array}$ & $\begin{array}{l}\text { Dichloromethane extracts; } \\
\text { TA } 100\end{array}$ & $\begin{array}{l}\text { Daily supplementation with vitamin } C \\
\text { and } E \text { resulted in reduction of fecal } \\
\text { mutagenicity. }\end{array}$ \\
\hline Kuhnlein 1983 & $(64)$ & $\begin{array}{l}\text { Low risk (non-meat) diet versus } \\
\text { high risk diet containing beef and } \\
\text { refined grains. }\end{array}$ & $\begin{array}{l}\text { Aqueous extract; TA } 98 \text { and } \\
\text { TA 100; fluctuation assay }\end{array}$ & $\begin{array}{l}\text { The high risk diet increased fecal } \\
\text { mutagenicity in both strains. }\end{array}$ \\
\hline Venitt 1986 & (65) & $\begin{array}{l}\text { Changing from a "normal" Westem } \\
\text { diet to a high fat, or high fiber diet }\end{array}$ & $\begin{array}{l}\text { Aqueous extract; TA } 100 \text { and } \\
\text { E. coli; fluctuation assay }\end{array}$ & $\begin{array}{l}\text { Feces collected during the high fiber } \\
\text { period were significantly less mutagenic }\end{array}$ \\
\hline \multicolumn{5}{|c|}{ Population studies: } \\
\hline Ehrich 1979 & $(66)$ & $\begin{array}{l}\text { Urban South African whites, } \\
\text { rural and urban blacks }\end{array}$ & $\begin{array}{l}\text { Ether extracts; TA } 98 \text { and } \\
\text { TA } 100 \pm \text { S9. }\end{array}$ & $\begin{array}{l}\text { High risk group (urban whites) excreted } \\
\text { more frequently mutagenic feces. }\end{array}$ \\
\hline Reddy 1980 & $(67)$ & $\begin{array}{l}\text { Omnivores, ovo-lacto } \\
\text { vegetarians and a low risk } \\
\text { Finish population }\end{array}$ & $\begin{array}{l}\text { Ether extracts; TA } 98 \text { and } \\
\text { TA } 100\end{array}$ & $\begin{array}{l}\text { High risk group showed greater muta- } \\
\text { genicity as compared to both low risk } \\
\text { populations. (NS) }\end{array}$ \\
\hline Correa 1981 & $(68)$ & $\begin{array}{l}\text { Postmortem cross-sectional } \\
\text { study comparing patients with } \\
\text { or without adenomatous polyps }\end{array}$ & $\begin{array}{l}\text { Dichloromethane extracts } \\
\text { washed with } \mathrm{NaOH} \text {; } \\
\text { TA } 100\end{array}$ & $\begin{array}{l}\text { No differences found (probably due to } \\
\text { small study population, } \mathrm{n} 1=28 \\
\mathrm{n} 2=53 \text { ) }\end{array}$ \\
\hline Kuhnlein 1981 & $(69)$ & $\begin{array}{l}\text { Strict vegetarians, ovo-lacto } \\
\text { vegetarians and omnivores }\end{array}$ & $\begin{array}{l}\text { Aqueous extracts; TA } 98 \text { and } \\
\text { TA } 100 ; \text { fluctuation test }\end{array}$ & $\begin{array}{l}\text { Omnivores excreted more mutagenic } \\
\text { feces. }\end{array}$ \\
\hline
\end{tabular}


Table I: continued

\begin{tabular}{|c|c|c|c|c|}
\hline \multicolumn{2}{|l|}{ Reference } & \multirow{2}{*}{$\begin{array}{l}\text { Research population/ } \\
\text { Dietary variables } \\
\text { Vegetarians and omnivores }\end{array}$} & \multirow{2}{*}{$\begin{array}{l}\text { Experimental conditions } \\
\text { DMSO and ethanol extracts; } \\
\text { Salmonella differential DNA } \\
\text { repair test }\end{array}$} & \multirow{2}{*}{$\begin{array}{l}\text { Main conclusions } \\
\begin{array}{l}\text { DNA-modifying compounds are more } \\
\text { often found in feces from omnivores. }\end{array}\end{array}$} \\
\hline Nader 1981 & $(70)$ & & & \\
\hline Mower 1982 & $(71)$ & $\begin{array}{l}\text { Rural Japanese and Hawaiian } \\
\text { Japanese }\end{array}$ & $\begin{array}{l}\text { Ether extract; TA } 98 \text { and } \\
\text { TA } 100 \mathrm{n} \pm \text { S9 }\end{array}$ & $\begin{array}{l}\text { Different assays were not consistent, } \\
\text { indicating effects of more than one } \\
\text { mutagen or presence of interfering } \\
\text { factors. }\end{array}$ \\
\hline Furgeson 1982 & $(72)$ & $\begin{array}{l}\text { Caucasians, polynesians and } \\
\text { ovo-lacto vegetarians }\end{array}$ & Ether extracts; TA 100 & $\begin{array}{l}\text { Trend for lower mutagenicity in low } \\
\text { risk polynesian group as well as in } \\
\text { the vegetarian group. }\end{array}$ \\
\hline Reddy 1985 & $(73)$ & $\begin{array}{l}\text { Rural and urban Finnish } \\
\text { populations at different risk for } \\
\text { colorectal cancer }\end{array}$ & $\begin{array}{l}\text { Anaerobic incubation; hexane/ether } \\
\text { extraction; TA } 98 \text { and TA } 100 \\
\pm \text { S9 }\end{array}$ & $\begin{array}{l}\text { Mutagenicity to both strains }+\mathrm{S} 9 \text { was } \\
\text { higher in the high risk urban population }\end{array}$ \\
\hline \multicolumn{5}{|c|}{ Case conrrol studies: } \\
\hline Bruce 1980 & $(74)$ & $\begin{array}{l}\text { Colorectal cancer patients versus } \\
\text { age-matched hemorrhoid controls }\end{array}$ & "Organic" extracts; TA 100 & $\begin{array}{l}\text { No significant differences between } \\
\text { patients and controls }\end{array}$ \\
\hline Askew 1980 & $(75)$ & $\begin{array}{l}\text { Colorectal cancer patients versus } \\
\text { controls }\end{array}$ & $\begin{array}{l}\text { Ether extracts, TA } 98 \text { and } \\
\text { TA } 100\end{array}$ & $\begin{array}{l}\text { No significant differences between } \\
\text { patients and controls }\end{array}$ \\
\hline Ferguson 1982 & $(72)$ & $\begin{array}{l}\text { Colorectal cancer parients versus } \\
\text { age- and sex-matched controls }\end{array}$ & Ether extracts; TA 100 & $\begin{array}{l}2 \text { of } 22 \text { colorectal cancer patients } \\
\text { showed mutagenic feces as compared to } \\
\text { none of } 18 \text { marched controls. }\end{array}$ \\
\hline Schiffman 1985 & $9(76)$ & $\begin{array}{l}\text { Colorectal cancer patients versus } \\
\text { age- an sex-matched controls }\end{array}$ & $\begin{array}{l}\text { Acetone extracts; TA } 98 \text { and } \\
\text { TA } 100\end{array}$ & $\begin{array}{l}\text { No difference in mutagenicity was } \\
\text { found between cases and controls. }\end{array}$ \\
\hline
\end{tabular}


two uther cumpounds in this fecal extract with chromatographic properties comparable to FP-12, also showed a mass spectrum with a molecular ion at $m / e$ 251 , it was concluded that these compounds are cis/trans isomers of FP-12.

The fecapentaenes appeared to originate from anaerobic microbiological production by several common species of Bacteroides, namely: $B$. fragilis, $B$. uniformis, B. thetaiotaomicron, B. ovatus and Bacteroides spp. 3452 A (110). Further, it was shown that their in vitro production required a fecal extract of a mutagen-producing donor and that this synthesis was greatly enhanced in presence of bile or bile acids (111-113). The role of bile acids in this microbiological synthesis is not understood, however, bile acids were suggested to solubilize the fecapentaene-precursors present in the fecal extract.

More recently, a phospholipid has been purified and characterized as fecapentaene precursor. Hydrolysis of the so called plasmalopentaenes by phospholipase $\mathrm{C}$ and lipase was shown to result in the generation of FP-12 or FP14 (114). The ultimate origin of the fecapentaenes can be either the diet or cell membranes of the colonic bacterial flora and human colon itself (115). After elucidation of the general structure of the fecapentaenes, several methods were developed to synthesize FP-12 and FP-14 as well as various fecapentaene analogues (116-121). The availability of these synthetic compounds initiated numerous studies on both in vitro and in vivo genotoxic effects of fecapentaenes and their mode of action.

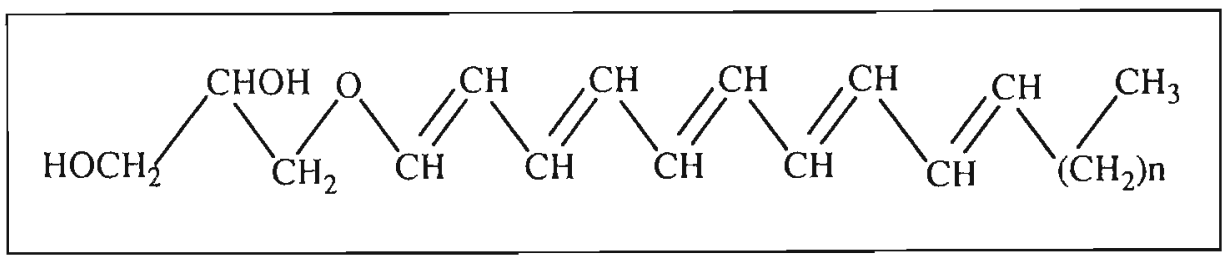

Fig. 2: Chemical structure of fecapentaene-12 $(n=1)$ and fecapentaene-14 $(n=3)$.

\subsection{Genotoxicity of fecapentaenes}

\section{In vitro genotoxicity}

Fecapentaenes were shown to posses direct mutagenic activity in Salmonella typhimurium strains TA 98 (a frameshift sensitive mutant) and TA 100 (a base pair substitution sensitive mutant) $(104,119,122-126)$. This mutagenicity may be reduced by addition of an exogenous metabolic activation system (rat liver S9 fraction) (124). Under anaerobic conditions, mutagenicity to strain TA 98 remains unaffected but is reduced in TA 100, suggesting a dual mechanism of action (125). Further, it was shown that synthetic FP-12 is mutagenic in strains TA 102 and 104 
which are sensitive to oxidant-mediated mutagenicity $(122,123,127)$. Studies on relations between chemical structure of the fecapentaenes and their mutagenic potential revealed that the mutagenic response depends on the conjugated 5 double bonds coupled to the enol ether oxygen. Reduction of the number of conjugated double bonds results in diminished mutagenicity $(124,126)$. The presence of the glycerol moiety, as well as the cis-trans configuration at the double bound adjacent to the ether linkage or the size of the terminal carbon chain attached to the conjugated system appear to be of little influence on the mutagenic activity (124). The mutagenic potency ranking order to Salmonella TA 100 was determined as: fecapentaene- $12>$ fecahexaene- $14>$ fecatetraene- 10 $>>$ hydroxy aldehyde (126).

In human fibroblasts, FP-12 was shown to increase mutation frequency at the hypoxanthine-guanine phosphoribosyltransferase ( $\mathrm{hprt}$ ) locus, and to induce DNA single strand breaks (SSB) and sister chromatid exchanges (SCE) (128). DNA-repair-deficient fibroblasts appeared more sensitive to both cytotoxic and mutagenic effects of FP-12. In human lymphocytes, a dose-response relationship was found for FP-12 exposure and the induction of both SSB's and SCE's in vitro (129). Further, dose dependent increases in unscheduled DNA synthesis in both rat hepatocytes and human fibroblasts, as well as neoplastic transformations in mouse BALB/c 3T3 cells were found after exposure to synthetic FP-12 (123). Finally, typical (pre)cancerous mucin histochemical changes were induced by FP12 in an in vitro human colon explant model (130). Results of studies on in vitro

Table II : In vitro genotoxicity of synthetic fecapentaenes.

\begin{tabular}{cccc}
\hline Test system & $\begin{array}{c}\text { FP-induced } \\
\text { activity }\end{array}$ & Dose & References
\end{tabular}

\begin{tabular}{|c|c|c|c|c|}
\hline \multirow{4}{*}{ Salmonella } & TA 98 & reversion & 0-40 $\mu \mathrm{mol} / \mathrm{platce}$ & $119,122-125$ \\
\hline & TA 100 & reversion & $0-40 \mu \mathrm{mol} /$ plate & $119,122-126$ \\
\hline & TA 102 & reversion & $0-40 \mu \mathrm{mol} / \mathrm{plate}$ & 122 \\
\hline & TA 104 & reversion & $0-40 \mu \mathrm{mol} / \mathrm{plate}$ & 119,123 \\
\hline \multirow{2}{*}{\multicolumn{2}{|c|}{$\begin{array}{l}\text { E. coli WP2uvrA } \\
\text { E. coli PQ37 }\end{array}$}} & reversion & $0-16 \mu \mathrm{mol} / \mathrm{plate}$ & 125 \\
\hline & & $\begin{array}{l}\text { B-galactosidase } \\
\text { induction }\end{array}$ & $0-0.56 \mu \mathrm{mol} / \mathrm{well}$ & 131 \\
\hline \multirow{2}{*}{\multicolumn{2}{|c|}{$\begin{array}{l}\text { Mouse BALB/c } 3 T 3 \text { cells } \\
\text { Rat hepatocytes }\end{array}$}} & transformation & $0-8.8 \mu \mathrm{M}$ & 123 \\
\hline & & UDS & $0-66 \mu \mathrm{M}$ & 123 \\
\hline \multirow{4}{*}{\multicolumn{2}{|c|}{ Human fibroblasts }} & hprt & $0-2 \mu \mathrm{M}$ & 128 \\
\hline & & SSB & $0-20 \mu \mathrm{M}$ & 128 \\
\hline & & SCE & $0-10 \mu \mathrm{M}$ & 128 \\
\hline & & UDS & $0-20 \mu \mathrm{M}$ & 123 \\
\hline \multirow{2}{*}{\multicolumn{2}{|c|}{ Human lymphocytes }} & SCE & $2-24 \mu \mathrm{M}$ & 129 \\
\hline & & SSB & $2-24 \mu \mathrm{M}$ & 129 \\
\hline \multicolumn{2}{|c|}{ Human colon explants } & Sialomucin secretion & $0-1 \mathrm{nM}$ & 130 \\
\hline
\end{tabular}


genotoxicity of FP-12 are summarized in Table II.

Quantitative assessment of the genotoxic potential of the fecapentaenes showed that compared to the direct acting mutagens $\mathrm{N}$-methyl- $\mathrm{N}$-nitrosourea and formaldehyde, FP-12 is at a molar basis respectively 900 -fold and 300 -fold more mutagenic at the hprt locus in normal human fibroblasts (128). Determination of the relative genotoxicity using the SOS Chromotest revealed that FP-14 was almost as active as the direct acting reference mutagen 4-nitroquinoline, whereas FP- 12 appeared only $25 \%$ as active as FP-14 (131).

\section{In vivo genotoxicity.}

Since it became clear that fecapentaenes reveal remarkable high genotoxicity in vitro, several in vivo studies have been conducted to establish (pre)carcinogenic effects (Table III). In one of the first studies, mice were exposed to FP-12 by intrarectal administration of suppositories. No increased level of nuclear aberrations above the background level was found, although the increased number of mitotic figures indicated stimulated cellular proliferation (132).

Intrarectal exposure of Fischer rats to synthetic FP-12 induced an increase in single strand breaks, thymidine incorporation and labeling index. Simultaneously, the mitotic index in colonic epithelial cells was found to be reduced suggested incorporation of $\left[{ }^{3} \mathrm{H}\right]$ thymidine for DNA repair rather than de novo DNA synthesis (133). Ward and coworkers (134) studied the carcinogenic activity of synthetic FP-12 in a variety of rodent test systems. Rats and mice were given weekly doses of FP-12 intrarectally, by subcutaneous injection or dermal application during periods of 1 to 10 weeks. At any administration route, no significant increase in tumor incidence was found after FP-12 administration; however, 2 rats out of 17 receiving FP-12 intrarectally developed colon polyps. Replacement of FP-12 by its diacetyl ester, which is more soluble in lipophilic media and therefore is expected to pass cell membranes more easily, has also failed to initiate skin tumors after topical administration in mice (135). In contrast to these negative results, Weisburger et al. found neoplasms in liver, lung, glandular stomach and subcutaneous fibrosarcoma after i.p. injection of FP-12 solutions in newborn mice (136). It has been suggested that these contradictory results may be explained by the fact that defense enzyme systems, like superoxide dismutase and catalase which enable detoxification of potential mutagens such as hydrogen peroxide, superoxide and hydroxyl radicals, are not yet adequately developed in newborn mice as compared to adult animals. In the same study, no colonic tumors were found in F-344 rats after intrarectal infusion of FP-12, whereas an insignificantly increased incidence of fibrosarcomas and mammary carcinomas was found by Shamsuddin et al., following intrarectal injection in male F-344 rats (130). It has repeatedly been suggested that in order to establish actual exposure levels, appropriate quality control measures for fecapentaene decomposition should be included in each carcinogenicity experiment $(130,137)$.

\section{Molecular and genotoxic mechanisms}

The chemical structure of natural fecapentaenes is unlike that of any other classes of mutagens known so far, and the molecular mechanism underlying the strong mutagenic properties of these polyenol ethers of glycerol appeared an intriguing problem. Some possible interactions of FP-12 with macromolecules are shown in 
Table III: In vivo genotoxicity of synthetic fecapentaene-12.

\begin{tabular}{|c|c|c|c|c|}
\hline Administration route & Dose & Treatment regimen & Effect on target organ & References \\
\hline \multicolumn{5}{|l|}{ Tomice } \\
\hline intrarectal & $12.8 \mu \mathrm{mol} / \mathrm{animal}$ & single administration & $\begin{array}{l}\text { increased number of mitotic figures } \\
\text { in colonic epithelium }\end{array}$ & 132 \\
\hline intrarectal & $0.28 \mu \mathrm{mol} /$ week & during 7 weeks & none & 134 \\
\hline skin application & $2.2-12 \mu \mathrm{mol}$ & $\begin{array}{l}\text { single administration followed } \\
\text { by } 20 \text { weekly dose of } 2 \mu \mathrm{g} \mathrm{TPA} \text {. }\end{array}$ & none & 134 \\
\hline skin application & $1.1 \mu \mathrm{mol} /$ week & during 10 weeks & none & 134 \\
\hline subcutaneous & $0.28 \mu \mathrm{mol} / \mathrm{week}$ & during 7 weeks & none & 134 \\
\hline skin application & $3 \mu \mathrm{mol}^{*}$ & twice a week, for 5 weeks & none & 135 \\
\hline i.p. injection & $10.4-30.0 \mu \mathrm{mol} / \mathrm{kg}$ & total of 6 injections & $\begin{array}{l}\text { neoplasm formation in: liver, lung, } \\
\text { glandular stomach and } \\
\text { subcutaneous fibrosarcoma }\end{array}$ & 136 \\
\hline \multicolumn{5}{|l|}{ To E-344 rats } \\
\hline intrarectal & $1 \mathrm{nmol}$ & single surgical installation & $\begin{array}{l}\text { increased labeling index, alkali-labile } \\
\text { sites and thymidine incorporation in } \\
\text { colonic epithelial cells }\end{array}$ & 133 \\
\hline intrarectal & $0.92 \mu \mathrm{mol} /$ week & during 11 weeks & 2 rats of 25 developed colonic polyps & 134 \\
\hline intrarectal & $6.36 \mu \mathrm{mol} /$ week & during 10 weeks & none & 134 \\
\hline Granuloma pouch & $1.0-4.0 \mu \mathrm{mol}$ & single administration & none & 134 \\
\hline intrarectal & $56 \mu \mathrm{mol} / \mathrm{kg}$ & three times/week, for 9 weeks & none & 136 \\
\hline \multirow[t]{2}{*}{ intrarectal } & $0.5-5 \mathrm{pmol} /$ week & during 85 weeks & insignificant increase in fibrosarcomas & \\
\hline & & & and mammary carcinomas & 130 \\
\hline
\end{tabular}

* FP-12 diacetate. 
Figure 3. FP-12 has been suggested to cause DNA damage by two distinct routes either directly by alkylation, or indirectly via the formation of oxygen radicals or aldehydes generated during FP-12 decomposition. Alkylating properties of FP-12 have been demonstrated by the formation of a FP-12 addition product to a nucleophilic compound as well as by the reactivity toward thiols $(117,131,132)$. Formation of an electrophilic carbocation from FP-12 as a result of protonation and charge delocalization on the unsaturated chain has been postulated (138). This reaction may generate several reactive sites in the fecapentaene molecule, which in turn may induce several types of DNA damage, i.e. DNA-single strand breaks and DNA-interstrand cross-links. Both types of DNA interactions have been observed by electron microscopy in plasmid DNA and were found by alkaline elution analysis of FP-12 exposed DNA from fibroblasts (139). The lack of alkali-labile sites, a lesion which is generally associated with the formation of DNA adducts at the phosphate backbone, may indicate that FP- 12 preferentially reacts with other sites in cellular DNA (140). It should be noted that the reaction conditions at which the nucleophilic additions were studied (117) were quite different from conditions at which mutagenicity is expressed in vivo. Several attempts to identify specific fecapentaene-nucleoside or DNA adducts have been made or are currently under investigation. Using synchronous fluorescence spectrophotometry, a characteristic single emission peak of FP-12 between 413 and 423 $\mathrm{nm}$ has been determined, allowing identification of non-radiolabeled FP-12 in DNA (130). Further, binding studies showed that after incubation of $\left[{ }^{3} \mathrm{H}\right]-\mathrm{FP}-12$ with

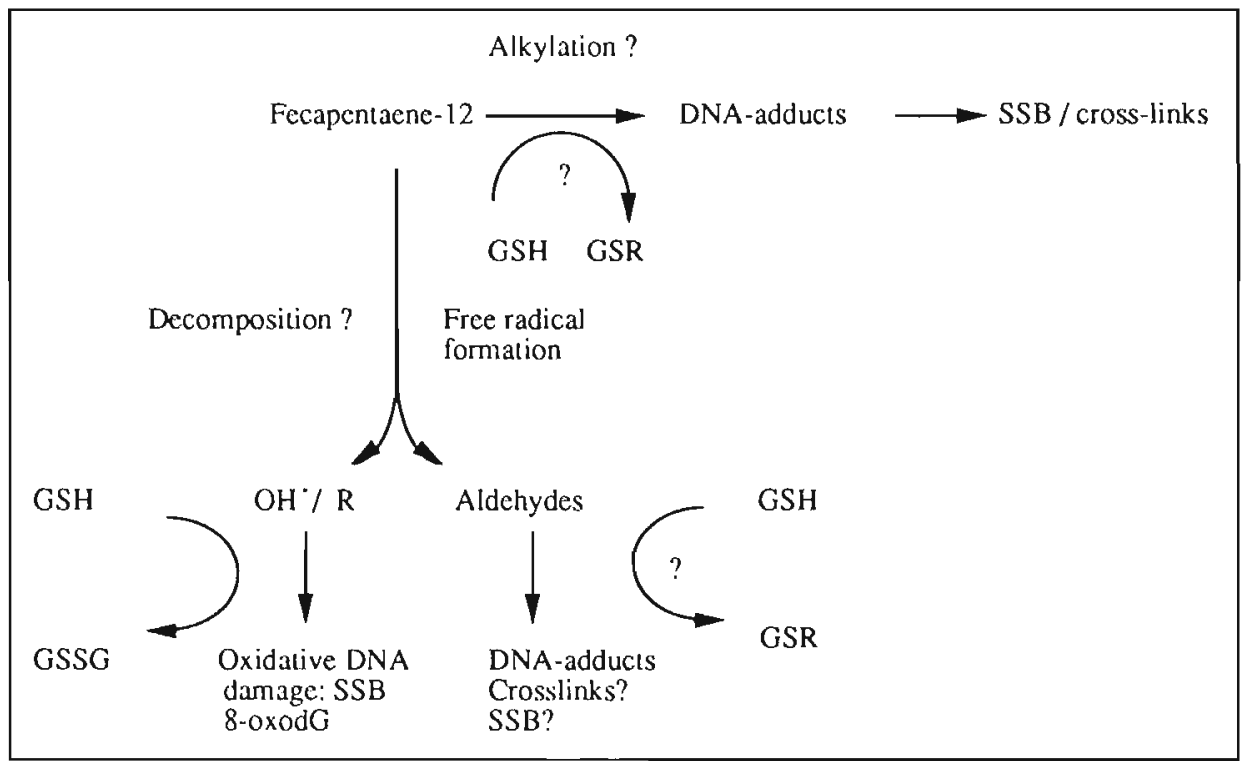

Fig. 3: Proposed genotoxic mechanisms of Fecapentaene-12. Genotoxic damage may be caused by 2 different mechanisms: either directly by alkylation, and/or indirectly by the generation of reactive decomposition products such as oxygen radicals or aldehydes. [Modified from Povey et al. (141,142)]. 
DNA, a small fraction of the radioactivity remained associated with DNA after repeated extractions and purifications (141). The formation of putative fecapentaene-adducted nucleotides was also indicated in preliminary $32 \mathrm{P}$ postlabelling studies $(141,142)$.

Oxygen radical formation is supported by the induction of 2'-deoxy-7,8-dihydro8-oxoguanosine (8-oxodG; frequently referred to as 8-hydroxydeoxyguanosine) in calf thymus DNA by FP-12 and FP-14 (143). Further, FP-12 appeared to be mutagenic in oxidant sensitive strains of Salmonella TA 102 and 104 $(122,123,127)$, whereas the mutagenicity to strain TA 100 was shown to be largely dependent upon the presence of oxygen (125). The formation of small amounts of oxidized glutathione (GSSG) after incubation of reduced glutathione (GSH) with FP-12 also supports the generation of oxygen radicals (139), although a decrease of cellular GSH was not found to be accompanied by measurable increased cellular GSSG levels (141). Furthermore, preliminary results from electron spin resonance (ESR) studies indicated hydroxyl and alkyl radical formation during a lipid peroxidation-type of decomposition process of FP-12 (141,142). Studies on the acid catalyzed solvolysis of FP-12 showed that the 10-hydroxy substituted aldehyde was formed instead of the expected aldehydes from a regular enol ether hydrolysis $(144,145)$. The same aldehyde appeared to be formed at neutral conditions in the presence of oxygen. These observations resulted in the proposal of a reaction sequence starting with a one-electron transfer from the electron-rich polyenol ether to oxygen. End-products of this reaction pathway are methoxyand hydroxy-substituted aldehydes, and esters, as well as peroxides like $\mathrm{H}_{2} \mathrm{O}_{2}$ and hydroxyl radicals, which in turn may induce oxidative DNA damage (146).

In conclusion, experimental results indicate that both DNA alkylation and oxidative DNA damage may be induced by fecapentaene exposure. Questions that remain to be answered by further research include:

1) Which reactive intermediates are involved in the induction of either form of DNA damage?

2) What conditions are required for the formation of these intermediates?

3) Do both types of DNA damage relate to the induction of genotoxic effects as previously observed in various testing systems?

4) Does in vivo exposure of human colon epithelium to fecapentaenes induce these types of genetic damage?

\subsection{Epidemiological aspects of fecapentaene excretion}

\section{Fecapentaene quantification and occurrence in human populations}

In view of the high in vitro genotoxic potential of FP-12, it has been hypothesized that excretion of high concentrations of fecapentaenes may relate with high risk for developing colorectal cancer. Therefore, the occurrence of fecapentaenes has been investigated in several different human populations. Main objectives of these studies were to determine: 
1) the level of colonic fecapentaene exposure,

2) possible effects of the diet on fecapentaene-excretion,

3) whether groups at different risk for colorectal cancer excrete different concentrations of fecapentaenes.

For fecapentaene extraction, various procedures have been described, using diethylether $(58,104,110,111)$, acetone $(81,97,98,147)$ or dichloromethane $(99,148)$ as extraction solvents and antioxidants like butylated hydroxytoluene and triethylamine as stabilizing factors (149). Several methods have been developed to reduce fecapentaene decomposition or to correct for fecapentaene-loss during extraction and purification, including isotopic dilution techniques (100), use of internal standards such as synthetic fecapentaene analogues that do not occur naturally, e.g. FP-13 (101), or by chemical conversion of fecapentaenes and their precursors to more stable methoxytetraenols (101). A clear limitation of this last approach is that actual fecapentaene exposure levels cannot be determined, since both fecapentaenes and their phospholipid precursors are assessed without discrimination. Although fecapentaenes can be analysed by GC (150), for quantitative analyses fecapentaenes are separated without exceptions by HPLC.

Application of these methods to feces from human populations has shown interindividual variation in excreted concentrations, varying from non-detectable levels (<20 ng/g dry feces) up to $10,000 \mathrm{ng} / \mathrm{g}$ dry feces or even more (81,97-101). Measurement of intraindividual day-to-day variation showed relatively low variation coefficients of $60-110 \%(142)$. The majority $( \pm 80 \%)$ of Caucasians on a Western diet, a population to which fecapentaene analysis so far has been restricted, has been shown to excrete detectable levels of fecapentaenes $(81,97,98)$. No data are available on the distribution of separate levels of FP-12 and FP-14 on the population level.

\section{Dietary effects on fecapentaene excretion}

Several reasons can be indicated to investigate correlations between the human diet and fecapentaene excretion. First, diet is generally considered to be an important risk factor in colorectal cancer (29). Further, it has been demonstrated that dietary habits may influence fecal mutagenicity to Salmonella TA 100 at the same conditions as fecapentaene mutagenicity is expressed $(59,62,63,79,80,151)$. And finally, the diet has been proposed to provide fecapentaene-precursors $(114,115)$. Even if fecapentaenes do not originate from dietary factors, dietary habits may still be of influence, for instance by affecting the composition of the anaerobic microbial flora in the bowel, and thereby fecapentaene-synthesizing conditions.

Until now, little is known about dietary effects on excreted fecapentaene concentrations. In a dietary intervention study, the effect of changing the amount and type of fat on fecal fecapentaene levels was studied. No differences were observed in fecapentaene concentrations during periods of 4 months on highversus low-fat diets or at different ratios of polyunsaturated to saturated fatty acids (147). A correlational study among 50 subjects with benign gastrointestinal disorders and 30 healthy subjects showed an inverse association between consumption of citrus fruits, supplemental vitamins $\mathrm{C}$ or $\mathrm{E}$, margarine and butter (151). Intake of carotene, fruits and dietary fiber were also inversely correlated with fecapentaene excretion in the study population without intestinal complaints. 
Similar findings of decreased fecal mutagenicity to Salmonella TA 100 following vitamin $C$ supplementation were observed, however, no actual fecapentaene concentrations were quantified in this study (63). In addition, during an ascorbic acid depletion period of 1 month, fecapentaene excretion was found to be increased, further supporting the hypothesis that vitamin $\mathrm{C}$ may affect fecapentaene levels (152). However, the correlational studies that have been performed so far, do not provide information on which level (e.g. synthetic rate, stabilization, transit time etc.) dietary factors may influence fecapentaene excretion. Further research is also needed to discriminate between effects of the diet on excretion of FP-12 and FP-14 analogues separately.

\section{Fecapentaene excretion in relation to colorectal cancer}

As is indicated above, results from epidemiological studies relating risk for colorectal cancer and excretion of fecal mutagenicity to Salmonella TA 100 yielded conflicting results. Until now, only one case-control study has been performed attempting to correlate colorectal malignity to directly measured fecapentaene concentrations using HPLC (97). In contrast to the study hypothesis, fecapentaene excretion in 69 patients with adenocarcinoma of the colon or rectum appeared to be lower (median $<100 \mathrm{ng} / \mathrm{g}$ dry weight) as compared to 114 matched surgical controls (median $276 \mathrm{ng} / \mathrm{g}$ ). Indirect measurement of fecapentaene precursors, by anaerobic incubation of inoculated freeze dried feces, also tended to be lower in cases. The observed differences could not be explained by the colorectal diagnostic workup or bleeding. It was concluded that excretion of fecapentaenes is not associated with colorectal cancer risk. Further, is was suggested that analysis of fecapentaene concentrations near time of diagnosis may not reflect the situation during the earlier and more relevant stage of initiation in the carcinogenic process.

Based on these results, it was hypothesized that fecapentaene excretion protects against colorectal damage, although more information on production, metabolism, tissue binding and carcinogenicity is required to determine the plausibility of this hypothesis. Since the study of Schiffman $e t$ al. is the only study relating fecapentaene concentrations to colorectal malignity, more data on fecapentaene excretion patterns in colorectal cancer risk groups are necessary. In such a study, interfering effects of the diet as well as excretion of separate FP-12 and FP-14 analogues should be evaluated simultaneously.

\subsection{Outline of the thesis}

From the review on fecapentaene genotoxicity and excretion presented in paragraphs 1.2 to 1.4 , it may be concluded that the relation between diet and excreted fecapentaene concentrations is far from clear and that insufficient epidemiological data are available to establish the relevance of fecapentaenes in colorectal carcinogenesis. This in combination with the strong biological activity, the wide prevalence of the fecapentaenes and the unusual strong correlation observed in the case control study of Schiffman et al. (97) justifies further study relating fecapentaene concentrations to diet and malignity. Therefore, fecapentaene-excretion patterns have been investigated in various populations, 


\section{Chapter I}

trying to correlate dietary habits, fecal parameters and risk for developing colorectal cancer to excreted fecapentaene concentrations. In order to do so, an high pressure liquid chromatography (HPLC) analysis has been developed, which enables quantitative analysis of various fecapentaene-analogues. The analytical procedure is described and evaluated in chapter 2. This fecapentaene quantification method has been applied in two studies comparing two groups at different risk for colorectal cancer. In the first study, fecal fecapentaene concentrations have been compared between populations of habitual ovo-lacto vegetarians and omnivores, of which the latter is at relatively high risk for developing colorectal cancer. The dietary intake of several food constituents as well as fecal parameters like bile acid concentrations, defecation frequency and fecal $\mathrm{pH}$, have been related to excreted fecapentaene levels (chapter 3 ). In continuation of the results found in this study, an in vitro model is described in chapter 4 to test a new hypothesis for fecapentaene kinetics in the bowel. This hypothesis involves the adsorption of FP-12 to fiber material, which may be of importance for the bioavailability and fecal excretion of fecapentaenes. The effects of bile acids and calcium on the binding of FP-12 to fiber have also been studied.The second study comparing fecapentaene excretion in populations at different risk for colorectal cancer is described in chapter 5 . This study concems a case-control comparison between patients with colorectal adenomas and matched control individuals which are positively identified not to suffer from neoplasia in the large bowel.

Apart from the lack of epidemiological data to determine reliably the etiological role of fecapentaenes in colorectal carcinogenesis, the mechanism by which fecapentace genotoxicity is induced is still being discussed. So far two hypotheses have been suggested, one based on the induction of oxidative DNA damage, and the second proposing the formation of fecapentaene-(fragment) adducts to DNA. In chapter 6 , the formation of reactive oxygen species by FP- 12 has been studied using electron spin resonance spectroscopy (ESR). Further, the effect of oxygen radical scavenging on fecapentaene mutagenicity is investigated in several strains of Salmonella typhimurium. In succession to the results of this study, the induction of 8 -oxodG by synthetic FP-12 has been determined in nucleosides, isolated DNA and in human fibroblasts, using HPLC with electrochemical detection. For the analysis of putative fecapentaene-adducted nucleotides ${ }^{32} \mathrm{P}$ postlabelling techniques have been applied. In order to correlate the possible generation of reactive oxygen species and the induction of DNA damage to a biological effect, the inactivation of $\Phi$ X-174 DNA by FP-12 has been investigated at comparable incubation conditions (Chapter 7). All results and conclusions are discussed in Chapter 8.

\section{References}

1. Hill M.J. (1989) Aetiology of colorectal cancer: current concepts. Bailliere's clinincal gasteroenterology, 3, 567-592.

2. Faivre, J., Boutron, M.C., Hilon, P., Bedenne, L. and Klepping, C. (1985) Epidemiology of colorectal cancer. In: Joossens, J.V. (ed.) Diet and human carcinogenesis, Elsevier Science Publishers B.V., pp 123-135. 
3. Sinnige, H.A.M. and Mulder, N.H. (1991) Colorectal carcinoma: an update. Neth. J. Med., 38, 217-228.

4. Ziegler, R.G., Devesa, S.S. and Fraumenid, J.F. Jr (1986) Epidemiologic patterns of colorectal cancer. In: DeVita, V.T., Hellman, S. and Rosenberg. S.A. (eds) Important Advances in Oncology, JB Lippincott, Philadelphia,pp 209-232.

5. Silverberg, E. and Lubera, J.(eds) (1988) Cancer statistics, New York: Am. Cancer Society. CA 38, 2-22.

6. Stemmermann, G.N., Mandel, M. and Mower,. H.F. (1979) Colon cancer: Its precusors and companions in Hawaii Japanese. Natl. Cancer Inst. Monogr., 53, 175-179.

7. Correa, P. and Haenszel, W. (1978) The epidemiology of large bowel cancer. Advances in Cancer Research, 26, 1-141.

8. Peters, R.K., Garabrant, D.H., Yu, M.C. and Mack, T.M. (1989) A case-control study of occupational and dietury factors in colorectial cancer in young men by subsite. Cancer Res., 49, 5459-5468.

9. Whittemore, A.S., Wu-Williams, A.H., Lee, M., Shu, Z., Gallagher, R.P., Dengao, J., Lun, Z., Xianghui, W, Kun, C., Jung, D., Teh, C., Chengde, L., Yao, X.J., Paffenbarger, R.S. and Henderson, B.E. (1990) Diet, physical activity, and colorectal cancer among chinese in North-America and China. J. Natl. Cancer Inst., 82, 915926.

10. Chute, C.G., Willet, W.C., Colditz, G.A., Stampfer, M.J., Baron, J.A., Rosner, B. and Speizer, F.E. (1991) A prospective study of body mass, height, and smoking on the risk of colorectal cancer in women. Cancer Causes and Control., 2, 117-124.

11. Hu, J., Liu, Y, Yu, Y., Zhao, T., Liu, S. and Wang, Q. (1991) Diet and cancer of the colon and rectum: A casse-control study in China. Int. J. Epidemiol., 20, 362367.

12. Kune, G.A., Kune, S., Read, Al., MacGuwan, K. Penfold, C. and Watson, L.F., (1991) Colorectal polyps, diet, alcohol, and family history of colorectal cancer: A case-control study, Nutr. Cancer, 16, 25-30.

13. Monnet, E., Allemand, H., Farina, H. and Carayon, P. (1991) Cigarette smoking and the risk of colorectal adenoma in men. Scand. J. Gasteroenterol, 26, 758-762.

14. Drasar, B.S. and Irving, D. (1973) Environmental factors and cancer of the colon and breast. Br. J. Cancer, 27, 167-172.

15. Armstong, B. and Doll, R. (1975) Environmental factors and the incidence and mortality from cancer in different countries with special reference to dietary practice. Int. J. Cancer, 15, 617-631.

16. Carroll, K. and Khor, H.T. (1975) Dietary fat in relation to tumorigenesis. Prog. Biochem. Pharmacol., 10, 308-353.

17. Correa, P. (1981) Epidemiological correlations between diet and cancer frequency. Cancer Res., 41, 3685-3690.

18. Liu, K., Moss, M., Persky, V.Stamler, J., Garside, D. and Soltero, l. (1979) Dietary cholesterol, fat and fibre and colon cancer mortality, an analysis of international data. Lancet ii, 782-785.

19. Hill, M.J., Maclennen, R. and Newcombe, J. (1979) Diet and large bowel cancer in three socio-economic groups in Hong Kong. Lancet i, 436.

20. McKeown-Eyssen, G.E.M., and Bright-See, E. (1984) Dietary facturs in colon cancer: international relationships. Nutr. Cancer, 6, 160-170.

21. Yeung, K.S., McKeown-Eyssen, G.E., Li, G.F., Glazer, E., Hay, K., Child, P., 
Gurgin, V., Zhu, S.L., Baptista, J., Aloe, M., Mee, D., Jazmaji, V., Austin, D.F., Li, C.C. and Bruce, W.R. (1991) Comparisons of diet and biochemical characteristics of stool and urine between chinese populations with low and high colorectal cancer rates. J. Nall. Cancer Inst., 83, 46-50.

22. Tuyns, A.J., Kaaks, R. and Haelterman, M. (1988) Colorectal cancer and the consumption of foods: A case-control study in Belgium. Nutr. Cancer, 11, 189-204.

23. Wynder, E.L., Kajitani, T., Ishikawa, S., Dodo, H. and Takano, A. (1969) Environmental factors of the colon and rectum. II. Japanese epidemiological data. Cancer, 23, 1210-1220.

24. Modan, B., Barell, V., Lubin, F., Modan, M., Greenberg, R.A. and Graham, S. (1975) Low-fiber intake as an etiologic factor in cancer of the colon. J. Natl. Cancer Inst., 55, 15-18.

25. Jain,M., Cook, G.M., Davis, F.G., Grace, M.G., Howe, G.R. and Miller, A.B.(1980) A case-control study of diet and colorectal cancer. Int. J. Cancer, 26, 757-768.

26. Bristol, J.B., Emmet, P.M., Heaton, K.W. and Williams, R.C.N. (1985) Sugar, fat and the risk of colorectal cancer. Brit. Med. J. 291, 1467-1470.

27. Hirayama, T. (1985) Diet and cancer: feasibility and imporance of prospective cohor study. In: Joossen, J., Hill, M. and Geboers, J. (eds) Diet and human carcinogenesis, Excerpta Medica, Amsterdam, pp 191-198.

28. Garland, C., Shelkelle, R.B., Barrett-Connor, E., Criqui, M.H., Rossof, A.H. and Oglesby, P.F. (1985) Dietary vitamin D and calcium and risk of colorectal cancer: a 19-year prospective study in men. Lancet i, 307-309.

29. Hill, M.J. (1975) The etiology of colon cancer, CRC, Critical Rev. Toxicol., 4, 31 82.

30. Reddy, B.S. (1986) Diet and colon cancer: Evidence from human and animal model studies. In: Reddy, B.S. and Cohen, L.A. (eds): Diet, Nutrition and Cancer: A critical evaluation, 1, Boca Raton, F.L.: CRC Press, pp 47-65.

31. Silverman, S.J. and Andrews, A.W. (1977) Bile acids: Co-mutagenic activity in the Salmonella-mammalian-microsome mutagenicity test. Brief communication. J. Nall. Cancer Irust., 59, 1557-1559.

32. Wilpart, M., Mainguet, P., Maskens, A. and Robertfroid, M. (1983) Mutagenicity of 1,2-dimethylhydracine toward Salmonella typhimurium, co-mutagenic effect of secondary biliary acids. Carcinogenesis, 4, 45-48.

33. Nigro, N.D., Bhadrachari, N. and Chomchai, C. (1973) A rat model for studying colonic cancer: effect of cholestyramine on induce tumors. Dig. Col. Rect., 16, 438443.

34. Narisawa, T., Magadia, N.E., Weisburger, J.H. and Wynder, E.L. (1974) Promoting effect of bile acids on colon carcinogenesis after intrarectal instillation of $\mathrm{N}$-Methyl-N'-nitro-N-nitrosoguanidine in rats. J. Natl. Cancer Inst., 53, 10931097 .

35. Reddy, B.S., Narasawa, T., Weisburger, J.H. and Wynder, E.L. (1976) Brief communication: Promoting effect of sodium deoxycholate on colon adenocarcinomas in germf rec rats. J. Natl. Cancer Inst., 56, 441-442.

36. Cohen, B.I., Raicht, F.F., Deschner, E.E., Takahashi, M., Sarwal, A.M. and Fazzini, E. (1980) Effect of cholic acid feeding on N-methyl-N-nitrosurea induced colon tumors and cell kinetics in rats. J. Narl. Cancer Inst., 64, 573-578.

37. Martin, M.S., Justrabo, E., Jeannin, J.F., Leclerc, A and Marin, F. (1981) Effect of dietary chenodeoxycholic acid on intestinal carcinogenesis induced by 1,2 
dimethylhydrazine in mice and hamsters. Br. J. Cancer, 43, 884-886.

38. Burkit, D.P. (1971) Some neglected leads to cancer causation. J. Natl. Cancer Inst., 47, 913-919.

39. Burkit, D.P. (1971) Epidemiology of cancer of the colon and rectum. Cancer, 28, 313.

40. Hill, M.J. (1987) Dietary fat and human cancer. Anticancer Res., 7, 281292.

41. Reddy, B.S. (1988) Overview of diet and colon cancer. In: Basic and clinical perspectives of colorectal polyps and cancer. Alan R. Liss, Inc., New york, pp 111 121.

42. Bruce, W.R. (1988) Steps between diet and colon cancer. In: Basic and clinical perspectives of colorectal polyps and cancer. Alan R. Liss, Inc., New york, pp 123130.

43. Vogel, V.G., McPherson, R.S. (1989) Dietary epidemiology of colon cancer. Hematol. Oncol. Clin. North Am., 3, 35-63.

44. Cheah, P.Y., (1990) Hypotheses for the etiology of colorectal cancer-an overview. Nutr. Cancer 14, 5-13.

45. Pitot, H.C. (1990) Mechanisms of chemical carcinogenesis: theoretical and experimental bases. In: Cooper, C.S. and Grover P.L. (eds), Chemical carcinogenesis and mutagenesis I. Springer verlag Berlin, pp 3-29.

46. Weinberg, R.A., (1989) Oncogenes, antioncogenes, and the molecular bases of multistep carcinogenesis. Cancer Res., 49, 3713-3721.

47. Boutwell, R.K. (1964) Some biological aspects of skin carcinogenesis. Prog. Exp. Tumor Res., 4, 207-250.

48. Boutwell, R.K. (1985), Tumor promoters in human carcinogenesis. In: DeVita, V.T., Hellman, S. and Rosenberg, S.A. (eds) Important advances in oncology. J.B. Lippincott company, Philadelphia, pp 16-27.

49. Verma, A.K. and Boutwell, R.K. (1980) Effects of dose and duration of treatment with the tumor-promoting agent, 12-O-tetradecanoylphobol-13-acetatc, on mouse skin carcinogenesis. Carcinogenesis, 1, 271-276.

50. Hirota, N. and Yokoyama, T. (1985) Comparative study of abnomality in glycogen storing capacity and other histochemical phenotypic changes in carcinogen-induced hepatocellular preneoplatic lesions in rats. Acra Pathol. Jpn., 35, $1163-179$.

51. Weinstein, I.B. (1988) The origins of human cancer: Molecular mechanisms of carcinogenesis and their implications for cancer prevention and treatment - Twentyseventh G.H.A. clowes memorial award lecture. Cancer Res., 48, 4135-4143.

52. Schulte-Hermann, R. (1985) Tumor promotion in the liver. Arch. Toxicol., 57, $147-158$.

53. Vogelstein, B., Fearon, E.R., Baker, S.J., Nigro, J.M., Kern, S.E., Hamilton, S.R., Bos, J., Leppert, M., Nakamura, Y. and White, R. (1989) Genetic alterations accumulate during colorectal tumorigenesis. In: Cavenee, W., Hastie, N. and Stanbridge, E. (eds) Recessive oncogenes and tumor suppression, Cold Spring Harbor, New York.

54. Vogelstein, B., Fearon, E.R., Hamilton, S.R., Kern, S.E., Preisinger, A.C., Leppert, B.A., Nakamura, Y., White, R., Smits, A.M.M., and Bos, J.L. (1988) Genetic alterations during colorectal-tumor development. New Engl. J. Med., 319, 525-532.

55. Fearon, E.R. and Vogelstein, B. (1990) A genetic model for colorectal tumorigenesis. Cell, 61, 759-767. 
56. Sugarbaker, P.H., Gunderson, L.L. and Wittes, R.E., (1985) Colorectal cancer. In: DeVita, V.T., Hellman, S . and Rosenberg, S.A. (eds) Cancer, principles and practice of oncology, 1, 2nd edition, J.B. Lippincott company, Philadelphia, pp 795-885.

57. Ames, B.N. and Gold, L.S. (1991) Endogenous mutagens and the causes of aging and cancer. Mutat. Res., 250, 3-16.

58. Bruce, W.R., Varghese, A.J., Furrer, R. and Land, P.C. (1977) A mutagen in the feces of normal humans. In Hiatt, H.H., Watson, J.K. and Winston, J.A. (eds), Origins of human cancer. Cold Spring Harbor Laboratory Press, Cold Spring Harbor, NY, pp. 1641-1644.

59. Schiffman, M.H. (1986) Epidemiology of fecal mutagenicity. Epidemiologic Rev. 8, 92-105

60. Venitt, S. (1982) Mutagens in human faeces; are they relevant to cancer of the large bowel? Mutat. Res., 98, 265-286.

61. Reddy, B.S. (1986) Fecal mutagens as a function of diet. In I. Knudsen (ed.) Generic toxic'slogy of the diet. Alan R. Liss, New York, pp 213-224.

62. De Vet,. H.C.W., Sharma, C., and Reddy, B.S. (1981) Effect of dietary fried meat on fecal mutagenic and co-mutagenic activity in humans. Nutrition Reports International, 23, 653-660.

63 Dion, P.W., Bright-See, E.B., Smith, C.C. and Bruce, W.R. (1982) The effect of dietary ascorbic acid and tocopherol on fecal mutagenicity. Mutat. Res. 102, 27-37.

64. Kuhnlein, H.V., Kuhnlein, U. and Bell, P.A. (1983) The effect of short-term dietary modification on human fecal mutagenic activity. Mutat. Res., 113, 1-12.

65. Venitt, S., Bosworth, D. and Alldrick, A.J. (1986) Pilot study of the effect of diet on the mutagenicity of human faeces. Muragenesis, 1, 353-358.

66. Ehrich, M., Aswell, J.E., van Tassell, R.L., Wilkins, T.D. (1979) Mutagens in the fecces of 3 south-african populations at different levels of risk for colon cancer. Mutat. Res., 64, 231-240.

67. Reddy, B.S., Sharma, C., Darby, L, Laakso, K. and Wynder, E.L. (1980) Metabolic epidemiology of large bowel cancer: fecal mutagens in high- and low-risk populations for colon cancer: a preliminary report. Mutat. Re's., 72, $511-522$.

68. Correa, P., Paschal, J., Pizzolato, P., Pelon, W. and Lesley, D.E. (1981) Fecal mutigens and colorectal polyps: preliminary repon of an autopsy study. In: Bruce, W.R., Correa, P., Lipkin, M. (eds). Bunbury Report 7. Gastrointestinal cancer: endogenous factors. Cold Spring Harbor, NY: Cold Spring Harbor Laboratory, pP $119-127$.

69. Kuhnlein, U., Bergstrom, D. and Kuhnlein, H. (198I) Mutagens in feces from vegetarians and non-vegetarians. Mutat. Res., 85, 1-12.

70. Nader, C.J., Potter, J.C. and Weller, R.A. (1981) Diet and DNA-modifying activity in human fecal extracts. Nutrition Rep. Int., 33, 113-117.

71. Mower, H.F., Ichinotsubo, D., Wang. L.W., Mandel, M., Stemmermann, G., Nomura, A., Heilbrum, L., Kamiyama, S. and Shimada A. (1982): Fecal mutagens in two japanese populations with different colon cancer risks. Cancer Res. 42, 1164 1169.

72. Furgeson, L.R. and Alley, P.G. (1982) Faecal mutagens from population groups within New Zenland at different risk of colorectal cancer. In: Mutagens in our environment, Alan R. Liss, Inc, New York, 423-429.

73. Reddy, B.S., Sharma, C., Mathews, L., Engle, A., Laakso, K. Choi, K., Puska, P. and Korpella, R. (1985) Metabolic epidemiology of colon cancer: fecal mutagens in 
healthy subjects from rural Kuopio and urban Helsinki, Finland. Musat. Res., 152, 97-105.

74. Bruce, W.R.and Dion P.W. (1980) Studies relating to a fecal mutagen. Am J. Clin. Nutr., 33, 2511-2512.

75. Askew, A.R., Ward, M., Green, M.K. and Reiber, O. (1982): Fecal mutagenesis and colonic cancer. Aust. N.J. Surg. 52, 27-29.

76. Schiffman, M.H., Andrews, A.W., Van Tassell, R.L., Smith, L., Daniel, J., Robinson, A., Hoover, R.N., Rosenthal, J. Weil, R., Nair, P.P., Schwartz, S., Pettigrew, H., Batist, G., Shaw, R. and Wilkins, T.D. (1989): Case-control study of colorectal cancer and fecal mutagenicity. Cancer Res. 49, 3420-3424.

77. Venitt, S., Bosworth, D., (1986) Further studies on the detection of mutagenic and genotoxic activity in human faeces: aerobic and anearobic in fluctuation tests with $S$. typhimurium and E. coli, and the SOS chromotest. Mutagenesis, 1, 49-64.

78. Reddy, B.S., Sharma, C. and Wynder, E. (1980): Fecal factors witch modify the formation of fecal co-mutagens in high and low-risk population for colon cancer. Cancer Lett. 10, 123-132.

79. Reddy, B.S., Sharma, C., Mathews, L. and Engle, A. (1984): Fecal mutagens from subjects consuming a mixed-western diet. Mutat. Res. 135, 11-19.

80. Reddy, B.S., Engle, A, Katsifis, S., Simi, B., Bartram, H., Perrino, P. and Mahan, C. (1989) Biochemical epidemiology of colon cancer: Effect of types of dietary fiber on fecal mutagens, acid and neutral sterols in healthy subjects. Cancer Res. 49. 4629-4635.

81. Schiffman, M.H., Van Tassell, R.L., Andrews, A.W., Wacholder, S., Daniel, J., Robinson, A., Smith, L., Nair, P.P. and Wilkins T.D. (1989) Fecapentaene concentration and mutagenicity in 718 North American stool samples. Mutat. Res 222, 351-357.

82. Hayatsu, H., Arimoto, S. Togawa, K. and Makita, M. (1981): Inhibitory effect of the ether extract of human feces on activities of mutagens: inhibition by oleic and linoleic acids. Mutat. Res. 81, 287-293.

83. Hatch, F.T., MacGregor, J.T. and Zeiger E. (1986) Review: Putative mutagens and carcinogens in foods. VII Genetic toxicology of the diet. Environm. Mutagenesis, 8 , 467-484.

84. Bird, R.P. (1986) Effect of dietary components on the pathobiology of colonic epithelium: Possible relationship with colon tumorigenesis. Lipids, 21, 289-291.

85. Bruce, W.R. (1987) Recent hypotheses for the origin of colon cancer. Cancer Res., 47, 4237-4242.

86. O'Brien, J. and Morrissey, P.A. (1989) Nutritional and toxicological aspects of the Maillard browning reactions in foods. CRC Crit. Rev. Food. Sci. Nutr. 28, 211 249.

87. Sugimura, T., Sato, S., Ohgaki, H., Takayama, S., Nagao, M. and Wakabayashi, K. (1986) Mutagens and carcinogens in cooed food. In: I. Knudson (ed), Genetic toxicology of the diet, Alan R. Liss, Inc., New York, pp 85-107.

88. Suzuki, K., Bruce, W.R., Baptista, J., Furrer, R., Vaughan, d.J. an Krepinsky, J.J. (1986) Characterization of cytotoxic steroids in human faeces and their putative role in the etiology of human colonic cancer. Cancer Lett., 33, 307-316.

89. Ames, B.N. (1986) Food constituents as a source of mutagens, carcinogens and anticarcinogens. In: I. Knudsen (ed.), Generic toxicology of the diet. Alan R. Liss Inc., New York, pp. 3-32. 


\section{Chapter 1}

90. Owen, R.W., Dodo, M., Thompson, M.H. and Hill, M.J. (1987) Fecal steroids and colorectal cancer. Nurition and Cancer, 9, 73-80.

91. McKeigue, P.M., Adelstein, A.M., Marmot, M.G., Henly, P.J., Owen, R.W., Hill, M.J. and Thompson, M.H. (1989) Diet and fecal steroid profile in a South Asian population with a low colon-cancer rate. Am. J. Clin. Nutr., 50, 151-154.

92. Reddy, B.S., and Wynder, E.L. (1977) Metabolic epidemiology of colon cancer. Fecal bile acids and neutral sterols in colon cancer patients and patients with adenomatous polyps. Cancer, 39, 2533-2539.

93. Reddy, B.S., Martin, C.W. and Wynder, E.L. (1977) Fecal bile acids and cholesterol metabolites of patients with ulcerative colitis, a high-risk group for development of colon cancer. Cancer Res., 37, 1697-1701.

94. Van Faassen, A., Bol, J., van Dokkum, W., Pikaar, N.A., Ockhuizen, T. and Hermus, R.J.J. (1987) Bile acids, neutral steroids, and bacteria in feces as affected by a mixed, a lacto-ovovegetarian, and a vegan diet. Am J. Clin. Nurr., 46, 962-967.

95. Sperry, J.P., Salyers, A.A., and Wilkins, T.D. (1976) Fecal long chain fatty acids and colon cancer risk. Lipids, 11, 637-639.

96. Watabe, J. and Bernstein, (1985) The mutagenicity of bile acids using a fluctuation test. Mutat. Res., 158, 45-51.

97. Schiffman, M.H., Van Tassell, R.L., Robinson, A., Smith, L., Daniel, J., Hoover, R.N., Weil, R., Rosenthal, J., Nair, P.P., Schwartz, S., Pettigrew, H., Curale, S., Batist, G., Block, G. and Wilkins, T.D. (1989): Case-Control study of colorectal cancer and fecapentaene excretion. Cancer Res. 49, 1322-1326.

98. Schiffman, M.H., Bitterman, P., Viciana, A.L., Schairer, C., Russel, L., Van Tassell, R.L. and Wilkins T.D. (1988): Fecapentaenes and their precursors throughout the bowel- Results of an autopsy study. Mutat. Res. 208, 9-15.

99. Block, H.B., Dietrich, M.F., Leake, R., Laidlaw, S.A., Vinton, N.E. and Kopple, J.D. (1990): Fecapentaene excretion: aspects of excretion in newborn infants, children and adult normal subjects and in adults maintained on total parenteral nutrition. Am. J. Clin. Nutr. 51, 698-704.

100. Pelers, J.H., Nolen, H.W., Gordon, G.R., Bradford, W.W., Bupp, J.E. and Reist, E.J. (1989): Combined chromatographic-isotopic dilution analysis of fecapentaenes in human feces. J. chromatogr. 488, 301-313.

101. Kivits, G.A.A., de Boer, B.C.J., Nugteren, C.H., van der Steeg, M., Vertegaal, L.B.J. and van der Gen, A., (1990), Quantitative HPLC analysis of the level of fecapentaenes and their precursors in human feces by a chemical conversion method. J. Nat. Prod. 53, 42-49.

102. Bruce, W.R., Varghese, A.J., Land, P.C. and Krepinsky, J.J. (1981) Properties of a mutagen isolated from feces. In: Bruce, W.R., Correa, P., Lipkin, M. (eds). Banbury Report 7. Gastrointestinal cancer: endogenous factors. Cold Spring Harbor, NY: Cold Spring Harbor Laboratory, pp 227-238.

103. Kingston, D.G.I., Wilkins, T.D., van Tassell, R.L., MacFarlane, R.D. and McNeal, C.J., (1981) Structural studies on a mutagenic bacterial product from human feces. In: Bruce, W.R., Correa, P., Lipkin, M. (eds). Banbury Report 7. Gastrointestinal cancer: endogenous factors. Cold Spring Harbor, NY: Cold Spring Harbor Laboratory, pp 215-226.

104. Wilkins, T.D., Lederman, M., Van Tassell, R.L., Kingsion, D.G. and Henion, J. (1980) Characterization of mutagenic bacterial product in human feces. Am. J. Clin. Nutr. 33, 2513-2520.

105. Gupta, I., Baptista, J., Bruce, W.R., Che, C.T., Furrer, R., Gingerich, J.S., Grey, 
A.A., Marai, L., Yates, P. and Krepinsky, J.J. (1983) Structures of fecapentaenes, the mutagens of bacterial origin isolated from human feces. Biochemistry, 22, 241 245.

106. Bruce, W.R., Baptista, J., Che, T., Furrer, R., Gingerich, J.S., Gupta, I. and Krepinsky, J.J. (1982) General structure of "fecapentaenes" the mutagenic substances in human faeces. Naturwissenschaften, 69, 557-558.

107. Hirai, N., Kingston, D.G.I., Van Tassell, R.L. and Wilkins, T.D. (1982) Structure elucidation of a potent mutagen from human feces. J. Am. Chem. Soc., 104, 6149 6150.

108. Marococcia, J.F., Csizmadia I.G. and Yates, P. (1988) An ab initio study of model compounds of fecapentaenes. J. Molec. Struct, 167, 359-394.

109. Baptista, J., Krepinsky, J.J. and Pfaendler, H.R. (1987) Natural fecapentaene-14 and one fecapentaene-12 component are all-trans stereoisomers. Angew. Chem. Int. Ed. Engl., 26, $1186-1187$.

110. Van Tassell, R.L., MacDonald, D.K. and Wilkins, T.D. (1982): Production of a fecal mutagen by bacteroides spp. Infection and Immunity 3, 975-980.

111. Van Tassell, R.L., MacDonald, D.K. and Wilkins, T.D. (1982) Stimulation of mutagen production in human feces by bile and bile acids. Mutat. Res. 103, 233239.

112. Van Tassell, R.L., Schram, R.M. and Wilkins, T.D. (1986): Microbial biosynthesis of fecapentaenes. In: I. Knudsen (ed.), Genetic toxicology of the diet, Alan R. Liss, Inc., New york, pp 199-211.

113. Lederman, M., Van Tassell, R.L., West, S.E., Ehrich, M.F. and Wilkins, T.D. (1980): In vitro production of human fecal mutagen. Mutat. Res. 79, 115-124.

114. Van Tassell, R.L., Piccariello, T., Kingston, D.G., Wilkins, T.D. (1989) The precursors of fecapentaenes: Purification and properties of a novel plasmalogen. Lipids 24, 454-459.

115. Kingston, D.G.I., Piccariello, D.T., Keyes, R.F., Van Tassell, R.L. and Wilkins, T.D. (1989) Isolation and structure elucidation of plasmalopentaene- 12 the biological precursor of fecapentaene-12. Tetrahedron Lett. 30, 6665-6668.

116. De Wit, P.P., Van Schaik, T.A.M. and Van der Gen, A. (1984) A convenient synthesis of fecapentaene- 12 by the Homer-Wittig reaction. Recl. Trav. Chim. PaysBas, 103, 369-370.

117. De Wit, P.P., Van der Steeg, M. and Van der Gen, A. (1986) Remarkable electrophilic properties of the pentaenol ether system of fecapentacne-12. Tetrahedron letters, 27(51), 6263-6266.

118 Nicolaou, K.C., Zipkin, R. and Tanner, D. (1984) Total synthesis of the potent mutagen (S)-3-(Dodeca-1,3,5,7,9-pentaenyloxy)propane-1,2-diol. J. Chem. Soc., Chem. Commun., 349-350.

119. Govindan, S.V., Kingson, D.G.I., Gunatilaka, A.A.L., van Tassell, R.L., Wilkins, T.D., de Wit, P.P., van der Steeg, M and van der Gen, A. (1987), Synthesis and biological activity of analogs of fecapentaene-12. J. Nat. Prod., 50, 75-83.

120. Kassaee, M.Z. and Kingston, D.G.I. (1987) Synthesis of $\left[6^{-2} \mathrm{H}\right]$ and $\left[6-{ }^{3} \mathrm{H}\right]$ fecapentaene-12, J. Lab. Comp. Radio., 24, $1071-1076$.

121. Pfaendler, H.R., Maier, F.K., Klar, S. and Göggelmann, W. (1988) Racemic and enantiomeric all-trans fecapentaene-12 and-14. Liebigs Ann. Chem., 449-454.

122. Göggelmann, W., Maier, F.K. and Pfaendler, H.R. (1986) Mutagenicity of synthetic racemic fecapentaene-12. Mutat. Res. 174, 165-167. 
123. Curren, R.D., Putman, D.L., Yang, L.L., Hayworth, S.R., Lawlor, T.E., Plummer, S.M. and Harris, C.C. (1987) Genotoxicity of fecapentaene-12 in bacterial and mammalian cell assay systems. Carcinogenesis, 8. 349-352.

124. Peters, J.H., Riccio, E.S., Stewart, K.R. and Reist E.J. (1988) Mutagenic activities of fecapentaene derivatives in the Ames/Salmonella test system. Cancer Lett. 39 , 287-296.

125. Venitt, S. and D. Bosworth (1988) The bacterial mutagenicity of synthetic all-trans fecapentaene-12 changes when assayed under anaerobic conditions. Mutagenesis 3 , 169-173.

126. Voogd, C.E., Vertegaal, L.B.J., van der Steeg, M., van der Gen, A. and Mohn, G.R. (1990) Structure, chemical reactivity and in vitro mutagenic activity in a series of fecapentaene analogues. Mutation Res., 243, 195-199.

127. Levin, D.E., Hollstein, M., Christman, M.F., Schwiers, E.A. and Ames, B.N. (1982) A new Salmonella tester strain (TA 102) with A-T base pairs at the site of mutation detects oxidative mutagens. Proc. Natl. Acad. Sci. USA, 79, 7445-7449.

128. Plummer, S.M., Grafstrom, R.C., Yang L.L., Curren, R.D., Linnainmaa, K. and Harris, C.C. (1986) Fecapentaene-12 causes DNA damage and mutations in human cells. Carcinogenesis, 7, 1606-1609.

129. Schmid, E., Bauchinger, M., Braselmann, H., Pfaendler, H.R. and Göggelmann, W. (1987): Dose-response relationship for chromosome aberrations induced by fecapentaene-12 in human lymphocytes. Mutat. Res., 191, 5-7.

130. Shamsuddin, A.M., Ullah, A., Baten, A. and Hale, E. (1991) Stability of fecapentaene-12 and its carcinogenicity in F-344 rats. Carcinogenesis, 12, 601-607.

131. Nair, P.P., Shami, S., Sainz, E., Judd, J.T., Taylor, P.R. and Schatzkin, A. (1991) Quantitative assessment of the genotoxicity of fecapentaenes. Mutat. Res., 260, 153-157.

132. Vaughan, D.J., Furrer, R., Baptista, J. and Krepinsky, J.J. (1987) The effeci of fecapentaenes on nuclear aberrations in murine colonic epithelial cells. Cancer Letr., 37, 199-203.

133. Hinzman, M.J., Novotney, C., Ullah, A. and Shamsuddin, A.M. (1987) Fecal mutagen fecapentaene-12 damages mammalian colon epithelial DNA. Carcinogenesis, 8, 1475-1479.

134. Ward, J.M., Anjo, T., Ohannesian, L. Keefer, L.K., Devor, D.E., Donovan, P.J., Smith, G.T., Henneman, J.R., Streeter, A.J., Konishi, N., Rehm, S. Reist, E.J., Bradford, W.W. and Rice, J.M. (1988) Inactivity of fecapentaene-12 as a rodent carcinogen or tumor initiator. Cancer Letr. 42, 49-59.

135. Devor, D.E., Henneman, J.R., Keefer, L.K., Logsdon, D.L., Rice, J.M., Streeter, A.J. and Ward, J.M. (1991) Carcinogenicity study of fecapentaene-12 diacetate on skin painting in SENCAR mice. Cancer Lett., 56, 11-15.

136. Weisburger, J.H. Jones, R.C., Wang, C.X., Backlund, J.Y.C., Williams, G.M., Kingston, D.G.I., Van Tassell, R.L., Keyes, R.F., Wilkins, T.D., De Wit, P.P., Van der Steeg, M. and Van der Gen, A. (1990) Carcinogenicity tests of fecapentaene12 in mice and rats. Cancer Lett. 49, 89-98.

137. Streeter, A.J., Donovan, P.J., Anjo, T., Ohannesian, L., Sheffels, P.R., Wu, P.P., Keefer, L.K., Andrews, A.W., Bradford, W.W., Reist, E.J. and Rice, J.M. (1989) Decomposition and quality control considerations in biological work with fecapentaene preparations. Chem. Res. Toxicol. 2, 162-168.

138. Gupta, I., Suzuki, K., Bruce, W.R., Krepinsky, J.J. and Yates, P. (1984) A model study of fecapentaenes: mutagens of bacterial origin with alkylating properties. 
Science 225, 521-523.

139. Dypbukt, J.M., Edman, C.C., Sundqvist, K., Kakefuda, T., Plummer, S.M., Harris, C.C. and Grafström, R.C. (1989) Reactivity of fecapentaene-12 toward thiols, DNA and these constituents in human fibroblasts. Cancer Res., 49, 60586063.

140. Pullman, A. and Armbruster, A.M. (1979) On the sites and mechanisms of alkylation in the nucleic acids. Theoret. Chim. Acta, 50, 359-361.

141. Povey, A.C., Plummer, S.M., Grafstrom, R.C. and Harris, C.C. (1990) Genotoxic mechanisms of fecapentaene-12 in human cells. in Pariza, M.W., Aeschbacher, H.W., Felton, J.S. and Sato, S. (Eds.) Mutagens and Carcinogens in the Diet, Wiley-Liss, Chichester, pp. 155-166.

142. Povey, A.C., Schiffman, M., Taffe, B.G. and Harris, C.C. (1991) Laboratory and epidemiologic studies of fecapentaenes. Mutat. Res. 259, 387-397.

143. Shioya, M., Wakabayashi, K., Yamashita, K., Nagao,M. and Sugimura, T. (1989) Formation of 8-hydroxydeoxyguanosine in DNA treated with fecapentaene-12 an -14. Mutal. Res. 225, 91-94.

144. Vertegaal, L.B.J., van der Steeg, M. and van der Gen, A. (1989) Anomalous solvolysis of a polyenol ether of glycerol. Tetrahedron Lett., 30, 5639-5642.

145. Vertegaal, L.B.J. and van der Gen, A. (1990) Acid-catalyzed solvolysis of polyenol ethers. II. Effect of the degree of unsaturation. Tetrahedron, 46, 7301-7312.

146. Vertegaal, L.B.J., Voogd, C.E., Mohn, G.R. and van der Gen, A. (1989) Further studies on the mutagenic activity of fecapentaene-12 analogues and conclusions about their molecular mode of action. Mutat. Res., 281, 93-98.

147. Taylor, P.R., Schiffman, M.H., Jones, D.Y., Judd, J., Schatzikn,A., Nair, P.P., Van Tassell, R.L. and Block, G. (1988): Relation of changes in amount and type of dietary fat to fecapentaenes in premenopausal women. Mutat. Res. 206, 3-9.

148. Baptista, J., Bruce, W.R., Gupta, I., Krepinsky, J.J., Van Tassell, R.L. and Wilkins T.D. (1984): On distribution of different fecapentaenes, the fecal mutagens, in the human population.Cancer Letl. 22, 299-303.

149. Kleinjans, J.C., Pluijmen, M.H., Hageman, G.J. and Verhagen, H. (1989): Stabilization and quantitative analysis of fecapentaenes in human feces, using synthetic fecapentaene-12. Cancer Lett. 44, 33-37.

150. Hirai, N., Kingston, D.G., Van Tassell, R.L. and Wilkins, T.D. (1985) Isolation and structure elucidation of fecapentaenes-12, potent mutagens from human feces. $J$. Nat. Prod. 4, 622-630.

151. Schiffman, M.H. (1987): Diet and faecal genotoxicity. Cancer Surveys 6 653-672.

152. Jacob, A., Keley, D.S., Pianalto, F.S., Swendseid, M.E., Henning, S.M., Zhang, J.Z., Ames, B.N., Fraga, C.G. and Peters, J.H. (1991) Immunocompetence and oxidant defense during ascorbate depletion of healthy men. Am. J. Clin. Nutr., 54, 1302S-1309S. 



\title{
Quantitative analysis and identification of eight naturally occurring fecapentaene analogues in human feces by high performance liquid chromatography
}

\author{
T.M.C.M. de Kok, F. ten Hoor and J.C.S. Kleinjans.
}

Based on: Carcinogenesis, 12 (1991) 199-205 and J. Chromatogr. 580 (1992) 135-159.

\begin{abstract}
Fecapentaenes, highly potent fecal mutagens originating from intestinal bacterial production, have been suggested to play an essential role in the initiation of colorectal cancer. Reviewing the data on fecapentaene occurrence in man, the applied methodologies for fecapentaene extraction and analysis appear to be very inconsistent. Therefore, we compared several methods and developed an optimal extraction and purification procedure for fecapentaene quantification in human feces. This method is based upon a dichloromethane extraction of freeze-dried material with application of a potter homogenization instrument and subsequent HPLC-analysis in combination with photodiode array detection. This system enables us to detect and quantify at least 8 forms of fecapentaene-like substances generally occurring in human stool. We suggest that these peaks represent fecapentaene- 12 and fecapentaene-14, both with a geometric isomer, as well as fecapentaene analogues that have never been reported before. Applying this methodology on feces of a group of young healthy persons, we were able to detect fecapentaene levels ranging from $<5 \mu \mathrm{g}$ to $6 \mathrm{mg} / \mathrm{kg}$ feces, and in $40 \%$ of the samples higher than $1.0 \mathrm{mg} / \mathrm{kg}$ feces. The newly identified fecapentaenes represent $21.7 \%$ of total fecapentaene concentration in feces. It appears that some fecapentaenes are excreted in higher amounts by females as compared to males. Furthermore, we found that fecal mutagenicity to Salmonella tester strain TA 100 appeared lower than hypothesized on the basis of overall fecapentaene contents, and that fecal extracts diminish the mutagenic effect of synthetic fecapentaene-12 dramatically. Apparently, optimal conditions for fecapentaene extraction result also in an increased level of co-extracted anti-mutagenic substances. Determination of fecal mutagenicity as an index for fecapentaene excretion or colorectal cancer risk is therefore not suitable.

In order to assess the relevance of fecapentaenes in the etiology of colorectal cancer, we suggest that a distinction should be made between relative occurrence and degree of genotoxic effect in situ of the various fecapentaene analogues.
\end{abstract}




\section{Introduction}

Fecapentaenes form the group of most prevalent genotoxins found in the human colon and were first described in 1977 by Bruce et al.(1). These ether-linked lipids with a pentaenyl group $(2,3,4,5,6)$ originate from anaerobic bacterial production $(7,8,9)$, and have been suggested to play an essential role in colon carcinogenesis because of their strong mutagenic potential (10-16). In vivo, fecapentaene-12 (FP12) increased ${ }^{3} \mathrm{H}$-thymidine incorporation into colonic epithelial DNA, indicating that FP-12 may cause in situ genetic damage (17). In contrast, demonstration of in vivo carcinogenicity of FP-12 administered to rodents intra-rectally, subcutaneously or by skin painting, has initially failed $(18,19)$, and only an insignificant increase of carcinogenic events in rodent colon has been observed (20). The carcinogenic potential of FP-12 after intraperitoneal injection in newborn mice, however, was clearly demonstrated (20). Furthermore, in a case-control study, fecal excretion of fecapentaenes proved not to be elevated in patients with adenocarcinoma of the colon or rectum compared to controls $(21,22)$.

Since the results from genotoxicological and epidemiological studies seem difficult to reconcile, evaluation of colorectal cancer risk of endogenous exposure to fecapentaenes is not very reliable at this moment. This is enforced by the fact that fecapentaene analysis in human stool samples is complex. Applied methodologies for fecapentaene extraction, purification and HPLC analysis appear to be very inconsistent (7,20,23-26). Several apolar solvents are used for fecapentaene extraction, and usually butylated hydroxytoluene (BHT) is added for stabilization, which has been shown to provide suboptimal protection from degradation (27). Furthermore, fecapentaene concentrations are frequently determined as total fecapentaenes, without discrimination between FP-12 and fecapentaene-14 (FP14). In this study, therefore, we compare frequently used extraction procedures in search for the most optimal recovery of fecapentaenes from human stool. Further, we present an HPLC analysis that separates at least eight different forms of fecapentaenes in fecal extracts. We applied this new methodology to a series of feces samples of human subjects, in order to quantify fecal excretion of individual fecapentaenes. Additionally, levels of fecal mutagenicity of feces extracts, as assessed by the Salmonella mutagenicity assay, are related to fecapentaene concentrations.

\section{Materials and methods}

\section{Sample collection}

Stool samples were collected in plastic bags on dry ice and were stored at -20 oC. Before extraction, samples were defrosted, homogenized and freeze-dried overnight. Feces from one non-smoking male donor of 23 years was spiked with synthetic FP-12, provided by Professor Van der Gen (28), to determine extraction recoveries. Recovery of naturally occurring fecapentaenes was determined in stool samples from 4 female and 4 male subjects, aging 19 to 23 years $(21.7 \pm 1.5)$. Feces from 28 randomly selected healthy persons of both sexes (Table I) were collected to determine the quantitative distribution of fecapentaenes and fecal mutagenicity. 
Table I: Characteristics of the donor population.

\begin{tabular}{llll}
\hline & & males & females \\
\hline number of subjects & & 14 & 14 \\
body weight & $(\mathrm{kg})$ & $75.4( \pm 5.1)$ & $61.8( \pm 5.9)$ \\
age & (years) & $27.8( \pm 6.8)$ & $24.4( \pm 3.4)$ \\
smoking subjects & & 0 & 2
\end{tabular}

Number of (smoking) subjects of both sexes and their body weight and age (mean \pm S.D.).

\section{Extraction procedure}

All solutions used during sample preparation, were stabilized with 5\% TEA. All chemicals were of the purest grade commercially available. Extraction efficiency of naturally occurring FP-12 was compared in 8 feces samples, using di-ethylether, acetone and dichloromethane as extraction solvents. Also, effects of vortexing on fecapentaene recovery were compared with the efficiency of a potter homogenization instrument. After freeze-drying, $4 \mathrm{~g}$ of feces-equivalents were extracted twice with $20 \mathrm{ml}$ of solvent. Glass equipment was rinsed again with $10 \mathrm{ml}$ of solvent. The combined extracts were evaporated until dryness under a stream of nitrogen at $40^{\circ} \mathrm{C}$ (except for the di-ethylether-extracts), and immediately resolved in $4,5 \mathrm{ml}$ di-ethylether. Purification was performed on a freshly packed column of 2 ml di-ethylether pre-washed Silica-60 (Merck Darmstadt FRG). The glass tap, preventing the column from falling dry, was lubricated with graphite instead of the usual greasing, which appeared to retain considerable amounts of fecapentaenes. After sample application, the silica column was rinsed twice with $4,5 \mathrm{ml} \mathrm{di-}$ ethylether and subsequently eluted with $4,5 \mathrm{ml}$ di-ethylether/methanol/TEA $(7: 2: 1)$. This fraction was evaporated to dryness under a stream of nitrogen at 40 ${ }^{\circ} \mathrm{C}$ and immediately resolved in $800 \mu \mathrm{l}$ of methanol/TEA (99.5/0.5). Complete dryness of both silica and di-ethylether appeared to be essential. Stool samples were extracted in triplicate. Samples were stored at $-20^{\circ} \mathrm{C}$ until HPLC analysis.

\section{HPLC-analysis}

Fecapentaene-analyses were performed on a Kratos liquid chromatograph, consisting of two Spectroflow 400 pumps, programmed by a Spectroflow 450 gradient programmer. Chromatograms were recorded on a SP 4400 integrator, connected to a Waters 994 photodiode array detector, which enables point to point comparison of up- and downslope spectra with the apex-spectrum to determine peak purity, as well as execution of a library search for peak identification. A Spherisorb S5 ODS-2 column ( $250 \times 4.6 \mathrm{~mm}$. id.) was used as HPLC stationary phase, in combination with a guard column (ODS pellicular $30 \mathrm{x}$ $2.1 \mathrm{~mm}$ i.d.). During analysis the guard column was washed with methanol/ chloroform (50/50) for 15 minutes starting 5 minutes after injection, using a column switch method and an additional low-pressure pump. As mobile phase, two eluents were used in a binary gradient elution system of the following composition: acetonitrile / methanol / water / tetrahydrofuran in solvent $\mathrm{A}=7.6 / 11.8$ / 75.2 / 
Table II. HPLC gradient-elution profile.

\begin{tabular}{cc}
\hline time (min.) & \% solvent B \\
\hline 0.00 & 42.0 \\
7.00 & 42.0 \\
7.01 & 51.0 \\
8.00 & 56.0 \\
8.15 & 63.0 \\
11.00 & 63.0 \\
11.01 & 68.0 \\
12.00 & 75.0 \\
14.30 & 75.0 \\
15.10 & 90.0 \\
20.00 & 90.0 \\
20.10 & 100.0 \\
22.00 & 100.0 \\
25.00 & 42.0 \\
27.00 & 42.0 \\
\hline
\end{tabular}

HPLC gradient-elution profile, starting with sample injection at time $=0,0 \mathrm{~min}$. Solvent $\mathrm{A}=$ acetonitrile / methanol / water / tetrahydrofuran : $7.6 / 11.8 / 75.2 / 5.4$ and solvent $B=56.2 / 25.4 / 12.0 / 6.4$.
5.4 , and in solvent $\mathrm{B}=56.2 / 25.4$ $/ 12.0 / 6.4$. The gradient profile is represented in Table II. Both solvents were continuously flushed with helium. Total flow is $1.5 \mathrm{ml} / \mathrm{min}$. All extracts were analyzed twice. Dilutions of synthetic FP-12 were utilized for construction of calibration curves based upon peak area determination.

\section{Fecapentaene stability}

The stability of synthetic FP-12, stored at $-80{ }^{\circ} \mathrm{C}$ under nitrogen and protected from light, was determined over a period of 2 years. Solutions of $0,5 \mathrm{mg} / \mathrm{ml} \mathrm{FP-}$ 12 in ethanol were stabilized with 5\% tri-ethylamine (TEA) (27). Chromatographic properties of compounds derived from synthetic FP-12 after exposure to daylight during 1 hour and UV radiation (254 and $365 \mathrm{~nm}$ ) for 10 minutes, were established. These radiation effects were also studied in fecal dichloromethane extracts.

\section{Quantitutive distribution of fecapentaenes}

The extraction procedure as finally selected for routine fecapentaene quantification, was based on dichloromethane as extraction solvent and application of a potter instrument. This method was used for quantification of fccilpentaene excretion in individuals as described above.

\section{Mutagenicity testing}

The Salmonella mutagenicity assay was performed according to Maron and Ames (29) in tester strain TA 100 , the most sensitive strain for determining fecapentaene mutagenicity (11). The direct plate incorporation technique was used, because preincubation did not result in an increased mutagenic activity of synthetic FP- 12 (27). No metabolic activation system was added. Positive controls and solvent controls (methanol / TEA) were included in each test. Extractions tested for mutagenic activity were simultaneously analyzed by HPLC for fecapentaene content as described above. Samples containing 0.65 gram feces equivalents in $\mathrm{l} 00 \mu \mathrm{l}$ solvent per plate were tested in triplicate.

\section{Stutistical evaluation}

Analysis of variance was used for comparison of extraction efficiencies of different solvents. Since fecapentaene concentrations appeared not normally distributed, 
the Mann-Whitney non-parametric two-sample test was used for statistical comparison of unpaired samples. For comparison of concentrations of different fecapentaenes per individual the Wilcoxon matched-pair signed-ranks test was applied. Statistic evaluation of the mutagenicity was performed according to the method of least significant differences (LSD) (30), with a LSD value of 88 at a confidence level of $p<0.01$. Pearson correlation coefficients were calculated for correlating fecapentaene levels to mutagenicity scores.

\section{Results}

\section{Extraction recoveries}

Although di-ethylether extracted samples do not have to be evaporated until dryness before the purification on silica, these samples show significant lower total FP-12 contents compared to acetone and dichloromethane extracts (ANOVA, F = $5.2250, \mathrm{n}=8, \mathrm{p} \leq 0.05)$. Recovery of FP- 12 in di-ethylether extractions of spiked feces is improved from $52.2 \pm 2,2 \%$ (mean \pm S.D, $\mathrm{n}=6$.) to $64.6 \pm 9.1 \%$ by replacing standard shaking at room temperature by pottertube extraction. Acetone and dichloromethane extract equal amounts of fecapentaene- 12 to approximately $59.8 \pm 3.7 \%$ after vortexing at room temperature $(n=6)$. Potter extraction with dichloromethane, the procedure finally selected for routine extractions, yields a FP- 12 recovery of $78.0 \%(n=6)$ with an inter- and intra-assay variation of respectively $2.9 \%$ and $2.8 \%$. This recovery appears to be concentrationindependent.

\section{HPLC-analysis}

Analysis of extracted stool samples by the described gradient elution method, results in the separation of at least 8 compounds with an UV spectrum comparable to the spectrum of all-trans fecapentaene-12 [ = FP(14.0)]. Absolute limit of detection for synthetic FP-12 is $5 \mu \mathrm{g} / \mathrm{kg}$ wet feces. Figure 1 shows an HPLCchromatogram of a dichloromethane extract of feces from a healthy, non-smoking, 22 year old female subject who is apparently capable of producing 8 different forms of fecapentaenes simultaneously. Most peaks (except peaks of FP(12.2) and $\mathrm{FP}(13.2)$ ) have a high purity index (>95\%) and appear to be reliably matched with the spectrum of synthetic FP-12 (matching factor $>90 \%$ ). Extracts of feces samples from two other donors, one male and one female respectively 22 and 23 years of age, contain $\mathrm{FP}(12.2)$ and $\mathrm{FP}(13.2)$ in a pure form, that properly matches the FP-12 spectrum (matching factor 90\%). We suggest that $\mathrm{FP}(17.7)$ and $\mathrm{FP}(18.2)$ represent isomers of FP-14 based on their spectra and chromatography. In one third of the analyzed samples additional compounds occur with chromatographic properties that may lead to miss-identification on basis of retention times only. Their deviating spectra however, indicate that the majority of these compounds are not likely to be pentaenes or other polyenes like hexa- or tetra-enes (25). Using this photodiode array detection system, incorrect quantifications due to disturbing non-fecapentaene or impure peaks can be excluded. 


\section{Fecapentaene-stability}

Synthetic FP-12 stabilized with 5\% TEA and stored at $-80^{\circ} \mathrm{C}$ protected from light, shows no degradation over a period of two years. Fecapentaene levels in nonstabilized stool samples kept at $-20^{\circ} \mathrm{C}$ protected from light, are still unchanged after one year of storage. A shown in Figure 2a, exposure of synthetic FP-12 to daylight results in the formation of a second peak with a shorter retention time of 13.5 min.(FP(13.5)). Exposure of FP-12 to UV light (254 and $365 \mathrm{~nm}$ ) produces an additional third peak (FP(13.2)). Storage of the non-stabilized compound at room temperature for 3 days, protected from light, leaves synthetic FP-12 intact. Extraction of feces spiked with synthetic FP-12 does not affect the levels of FP(13.5) or FP(13.2). This indicates that the described handling of feces, extraction procedure and chromatography do not cause formation of these degradation or isomerization compounds of FP-12. Similar changes as in the chromatogram of

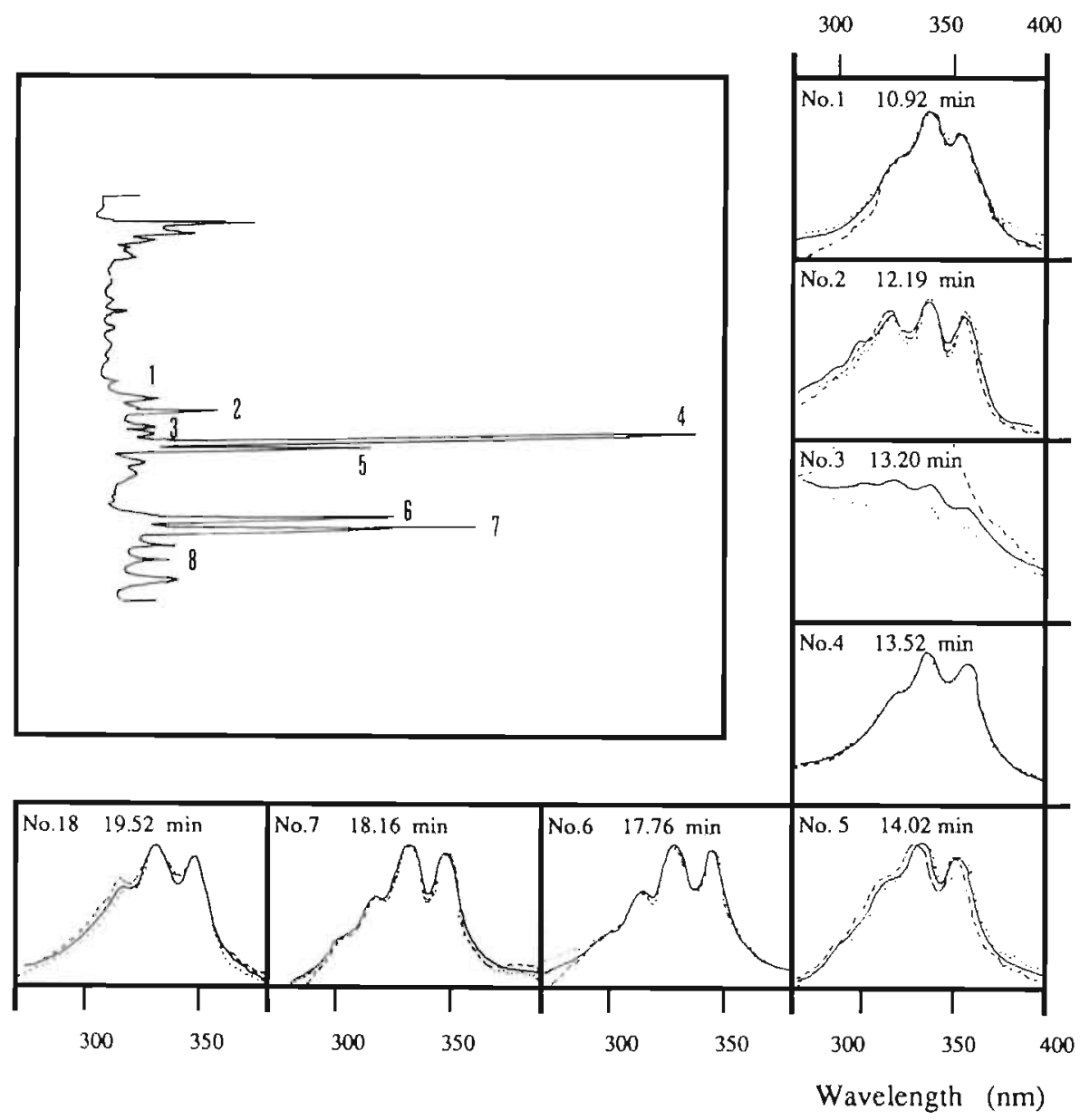

Fig 1: HPLC-chromatogram of a feces extract from a female subject. Peak-numbers are corresponding with the numbers of the spectra at the apex (-), upslope (…) and downslope (- - -). Peak and spectrum 5 represent all-trans FP-12. 
Fig 2: a) HPLC-chromatograms A: synthetic FP-12 (RT $=14.0$ min.); B: synthetic FP-12 after exposure for 1 hour to daylight, showing a peak of $\mathrm{FP}(13.5)$; $\mathrm{C}$ : Synthetic FP-12 after 10 minutes exposure to UV (254 $\mathrm{nm})$ showing a peak of $F P(13.2)$; b) HPLC-chromatograms of A: fecal extract with predominantly FP(18.2); B: The same extract after 1 hour exposure to daylight, showing a peak of FP(17.7); and C: The same extract after exposure to UV resulting in the formation of $\mathrm{FP}(17.4)$.
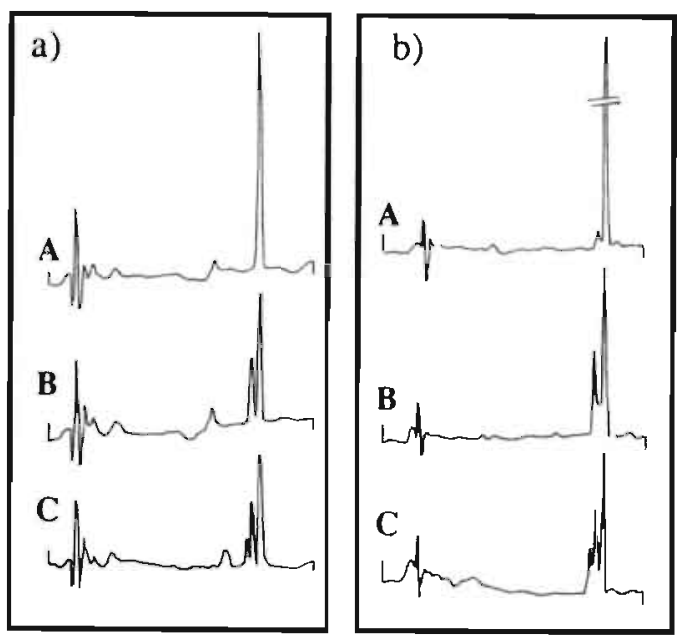

synthetic FP-12, are observed when an extracted stool sample containing predominantly FP(18.2) which is presumably FP-14, is exposed to daylight or UV radiation. This results in the formation of respectively $\operatorname{FP}(17.7)$ and $\operatorname{FP}(17.4)$ (Figure 2b). Further, all fecapentaenes [except FP(13.2)] occur in various fecal extracts as sole or most predominant compound. It is therefore not likely that some forms may originate from one or more natural fecapentaenes during sample preparation and analysis.

\section{Quantitative distribution of fecapentaenes}

Individual fecapentaenes as excreted by 28 males and females, are shown in Figure 3. Total fecapentaene concentrations present the sum of all quantified fecapentaene-analogues, and vary in the range of $0 \mu \mathrm{g}$ (detection limit $=5 \mu \mathrm{g} / \mathrm{kg}$ of wet feces for each form) to approximately $6 \mathrm{mg}$ per $\mathrm{kg}$ of wet feces, indicating that the inter-individual variation is very large in this population. The most prevalent forms, also presenting the highest concentrations, are FP(13.5) and FP(18.2), isomers of respectively FP-12 and FP-14. Isomeric forms of FP-12 are excreted in significantly different amounts (Wilcoxon $T=4, n=20, p<0.01$ ), with an average ratio $\mathrm{FP}(13.5) / \mathrm{FP}(14.0)$ of 3.7 . The ratio $\mathrm{FP}(18.2) / \mathrm{FP}(17.7)$ is 4.8 which indicates that the concentration of isomeric forms of FP-14 also differs significantly (Wilcoxon $T=4, n=18, p<0.01$ ). Further, a correlation has been found between concentrations of the FP-12 isomers FP(14.0) and FP(13.5), as well as between the FP-14 isomers FP(18.2) and FP(17.7) (respectively $r=0.919, n=20, p<0.01 ; r=$ $0.399, n=18, p<0.05$ ). Other possible interrelations between excreted amounts of different fecapentaenes did not gain statistical significance. The mean relative contribution of the newly identified fecapentaenes FP(10.9), FP(12.2) and FP(19.5) to total fecapentaene concentrations per individual is $21.7 \%$ ( $\pm 32.3 \%$ ). Total contribution of these particular analogues to overall fecapentaene excretion is $22.45 \%$. 

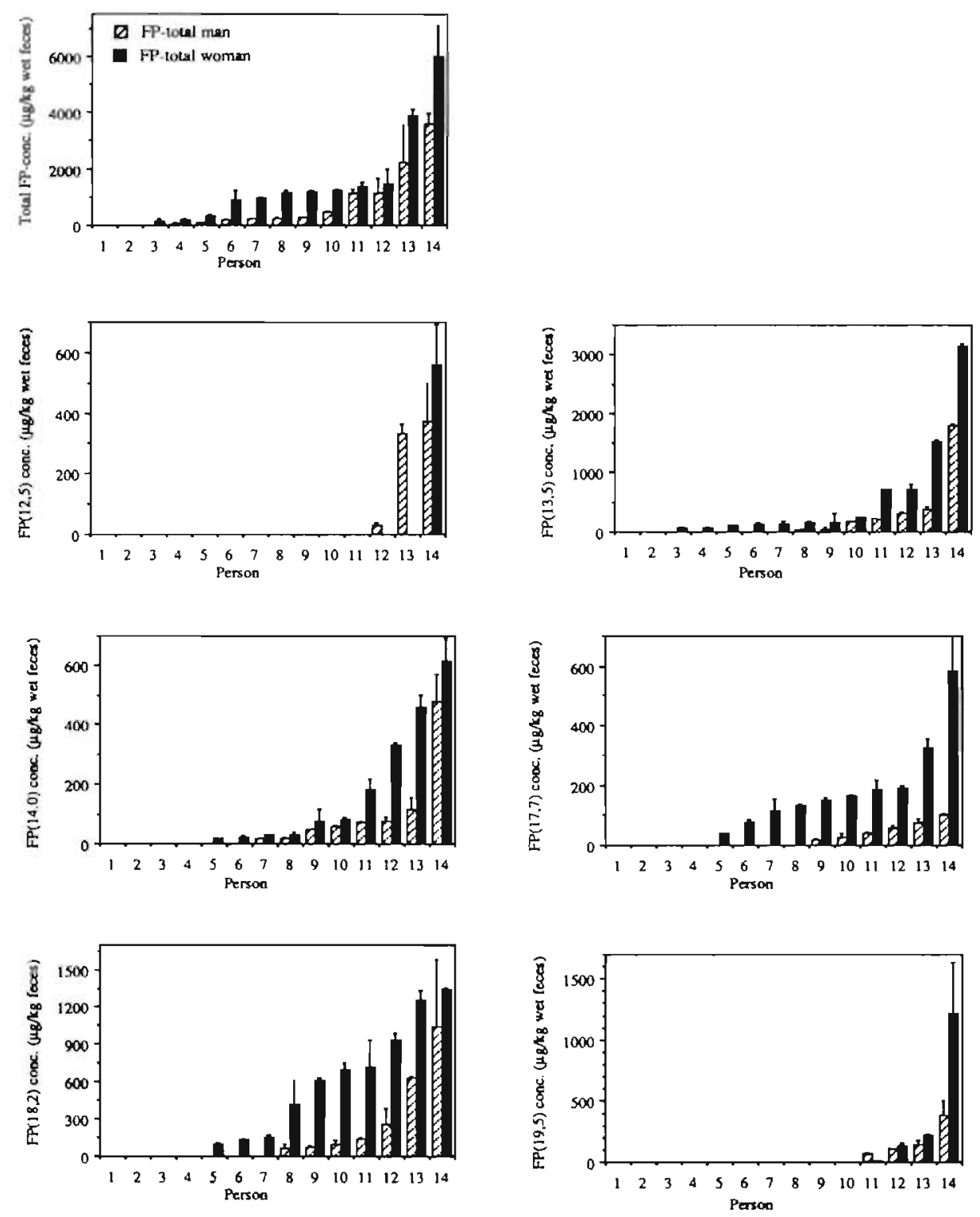

Fig 3: Individual excretion of fecapentaenes ( $\mu \mathrm{g} / \mathrm{kg}$ wet feces, mean \pm S.D.) for men (hatched columns) and women (solid columns) in ascending order. Numbers in parentheses indicate the retention time of the fecapentaene. FP(13.2), $\mathrm{FP}(13.5)$ and $\mathrm{FP}(14.0)$ are identified as isomeric forms of FP-12; $\mathrm{FP}(17.7)$ and FP(18.2) are identified as isomeric forms of FP-14. Both FP(10,9) and FP(13.2) occurred only twice in concentrations $<200 \mu \mathrm{g} / \mathrm{kg}$ wet feces, and are not graphically presented. 
For all fecapentaenes, females tend to show a higher fecal concentration as compared to males. However, these differences are only significant for FP(17.7) (Z $=2.513, \mathrm{n}=14, \mathrm{p}=0.012)$ and reach marginal statistical reliability for FP(13.5) and $\mathrm{FP}(18.2)$ (respectively $\mathrm{Z}=1.682$,

$\mathrm{n}=14, \mathrm{p}=0.092 ; \mathrm{Z}=1.801, \mathrm{n}=14, \mathrm{p}=0.070)$.

\section{Mutagenicity testing}

The dose-response curve for synthetic FP-12 mutagenicity is shown in Figure 4a, with a maximal mutagenic effect at a dose of $3 \mu \mathrm{g} \mathrm{FP-12}$ per plate. Mutagenicity of the extracted stool samples to Salmonella TA 100 as a function of total fecapentaene content is presented in Figure $4 \mathrm{~b}$. Of all samples, $80 \%$ shows a mutation frequency below the number of spontaneous revertants ( $=94$ revertants/plate). Only one sample exhibits a significant mutagenic effect that exceeds the LSD-value. All plates show a normal background lawn of bacteria. Further, a positive correlation is found between total fecapentaene concentration and mutagenicity, expressed as absolute number of revertants per plate using data for all extracts $(r=0.441, n=84, p<0.05)$. However, this correlation is mainly caused by the revertant scores of one significantly mutagenic feces sample. No significant correlations are found when individual fecapentaenes, including alltrans FP-12, are related to the number of revertants. In order to determine possible effects of anti-mutagenic compounds in fecal dichloromethane extracts on the expression of mutagenic activity of fecapentaenes, several extracts are supplemented with $1 \mu \mathrm{g} \mathrm{FP}-12$ per $100 \mu$ before mutagenicity testing. The fecal extracts, although also containing considerable levels of other naturally occurring fecapentaenes, decrease the mutagenic effect of FP-12 to TA 100 dramatically (Table III).
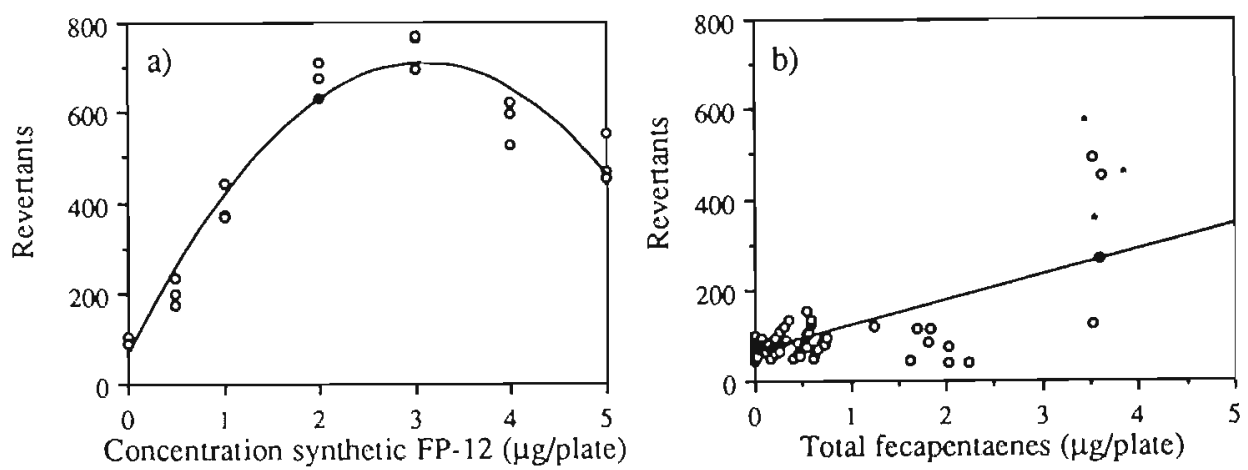

Fig 4: a) Reference dose-response relation for synthetic fecapentaene-12. b) Mutagenicity of in triply extracted stool samples $(n=84)$ to Salmonella tester strain TA 100 without $S 9 \mathrm{mix}$, as function of total fecapentaene concentration ( $\mu \mathrm{g} / \mathrm{plate}) .{ }^{*}$ significantly mutagenic as compared to control ( $\mathrm{p}<$ $0.01)$. 
Table III: Effect of fecal dichloromethane extracts on the mutagenicity of synthetic FP-12

\begin{tabular}{cccr}
\hline sample & $\begin{array}{c}\text { total } \\
\text { fecapentaenes } \\
(\mu \mathrm{g} / \text { plate })\end{array}$ & revertants/plate & $\begin{array}{c}\text { revertants/plate } \\
(+1 \mu g \text { synthetic } \\
\text { FP-12) }\end{array}$ \\
\hline control & 0.00 & $63 \pm 1$ & $366 \pm 29$ \\
1 & $0.05 \pm 0.00$ & $40 \pm 8$ & $66 \pm 7$ \\
2 & $0.13 \pm 0.01$ & $42 \pm 2$ & $61 \pm 5$ \\
3 & $1.14 \pm 0.17$ & $65 \pm 9$ & $96 \pm 8$ \\
4 & $0.48 \pm 0.19$ & $80 \pm 4$ & $159 \pm 26$ \\
5 & $1.96 \pm 0.13$ & $127 \pm 6$ & $176 \pm 5$ \\
6 & $0.70 \pm 0.07$ & $61 \pm 2$ & $87 \pm 13$
\end{tabular}

Fecapentaene content (mean \pm S.D.) of six extracted stool samples and their mutagenic activity in number of revertants/plate $( \pm$ S.D.) of six extracted stool samples separately, and after addition of $1 \mu \mathrm{g}$ synthetic FP-12/plate. Samples 1-3 originate from male donors; 4-6 from female donors.

\section{Discussion}

Comparison of different procedures for fecapentaene extraction from stool samples has shown that recoveries may vary substantially with the applied extraction solvent and method. Dichloromethane and acetone appear more efficient in extracting FP-12 as compared to di-ethylether, and application of a potter homogenization instrument additionally increases the extraction recovery up to $78 \%$. This indicates a remarkable improvement as compared to the $20 \%$ recovery achieved by Peters et al. (25), using BHT/TEA stabilized di-ethylether as extraction solvent. No further extraction recoveries of the various di-ethylether$(1,7,31,32)$, acetone- $(21,33-36)$ or dichloromethane-(23,26) based extractions used for fecapentaene quantification or determination of fecapentaene mutagenicity, have previously been reported. Also, effects on fecapentaene recovery of stabilization with BHT and purification on silica, have never been quantified. This complicates the interpretation of fecapentaene concentrations in human stool as reported in earlier studies (1,7,21,23,26,33-36).

The naturally occurring form of FP-12 has previously been suggested to be a mixture of cis-trans isomers of one or more of the double bonds in the pentaene system $(2,3,4)$. The developed HPLC analysis presented here, enables identification of eight forms of fecapentaenes extracted from human feces, three of which have never been reported before. Based on spectra comparison and the chromatographic properties of two compounds originating from synthetic FP-12 after exposure to UV light, it can be assumed that FP(13.2) and FP(13.5) represent geometric isomers of peak 5, which is all-trans FP-12. FP(17.7) and FP(18.2) very likely represent geometric isomers of FP-14. Using an isocratic HPLC-method, synthetic FP-14 clutes with a retention time of 18.7 minutes (A. van der Gen, personal communication). When samples containing $\mathrm{FP}(18.2)$ are analyzed under these particular isocratic conditions, a peak is found with the same retention time 
as obtained with synthetic FP-14. On the analogy of the isomerization pattern of FP-12, FP(18.2) is most likely to represent the all-trans form of FP-14, with FP(17.7) and FP(17.4) as geometric isomers. Since extraction and analysis of FP-12-spiked feces does not result in the elevation of fecapentaene levels other than FP(14.0), we feel confident that these fecapentaenes occur naturally and do not represent isomerization products as a consequence of the applied extraction procedure or storage at $-20^{\circ} \mathrm{C}$.

The newly reported $\mathrm{FP}(10.9), \mathrm{FP}(12.2)$ and $\mathrm{FP}(19.5)$ are not likely to be fecapentaene-oxidation products because oxidation shifts the UV spectrum dramatically $(24,27,31)$. Their retention times are furhermore too short for the precursor described by Van Tassell et al. (37) and Kingston et al. (38). However, they may represent fecapentaenes with less than twelve (FP(10.9) and FP(12.2)), or more than fourteen carbon-atoms (FP(19.5)) in the side chain. The existence of these fecapentaenes has been suggested before, but they have never been demonstrated in human feces (4).

After application of this analysis to stool samples of 28 healthy individuals, we find that the most abundant fecapentaene forms can be identified as FP-12 and FP-14. This is in agreement with previous reports on fecapentaene excretion $(2,4,8,23,25)$. The concentration range of 5 to $6000 \mu \mathrm{g} / \mathrm{kg}$ wet feces, in which fecapentaenes are found to be excreted, is considerably higher than initially reported (2), but more recently other investigators have detected fecapentaene levels in the same order of magnitude $(25,26,39)$. However, the method described by Block et al. (26) does not enable detection of quantifiable amounts of FP-14 in feces of any of their donors, whereas Peters et al. (25) report the occurrence after anacrobic incubation of pre-FP-12 and pre-FP-14, compounds that may be identical to $\mathrm{FP}(13.5)$ and $\mathrm{FP}(17.7)$ in our assay. In contrast, we find all-trans FP-12, the compound used as representative for all fecapentaenes in genotoxicity and carcinogenicity studies, to be excreted significantly less as compared to its isomer FP(13.5). All-trans FP-14 appears to occur in higher concentrations in comparison with excreted amounts of the FP-14 isomer FP(17.7). Analysis of spiked feces demonstrates that the occurrence of isomers of FP-12 is not an artifact caused by isomerization during storage or the extraction procedure. The correlation we find between the excretion of both geometric isomers of FP-12, suggests a common synthetic pathway, and that the relative occurrence represents a chemical equilibrium. This seems also indicated for the isomeric forms of FP-14. No correlations between excretion of other fecapentaenes are found. Therefore, the formation of fecapentaene analogues may require different dietary substrates, other chemical or physical conditions in the bowel, deviating microbial composition of the anaerobic flora, or combinations of these factors.

One third of the 28 extracted stool samples used for determining fecal mutagenicity, yields total fecapentaene concentrations higher than $0.5 \mu \mathrm{g}$ total-FP/ plate, and therefore can be expected to result in a significantly elevated number of revertants in the Salmonella assay. However, only one feces sample is found to be mutagenic, indicating that factors that inhibit the expression of mutagenicity to Salmonella, are co-extracted with the fecapentaenes. This is confirmed by the inhibiting effect of fecal extracts on the expression of mutagenicity of synthetic 
FP-12. Discrepancy between fecal fecapentaene levels and mutagenic potential of human stool samples has previously been reported $(34,39,40)$. Inhibition of expression of fecapentaene mutagenicity by fecal extracts may be due to the presence of some food-borne antimutagens and anticarcinogens in the stool samples, for instance natural antioxidants as ascorbic acid and tocopherols $(41,42)$. Other inhibitors might be retinoids, phenols, terpenes etc. occurring in fruits and vegetables. Furthermore, compounds as linoleic and oleic acid which occur in feces, have been shown to possess antimutagenic capacity (43). Therefore, these mutagenicity data do not provide a reliable index for mutagenic capacity of fecapentaenes. This may further explain the absence of significant associations found in previous studies attempting to correlate either diet and fecal mutagenicity (44-47), or fecapentaene excretion $(22,21)$ to colorectal cancer.

In evaluating risk for colorectal cancer of endogenous fecapentaene exposure, it is necessary to assess whether the novel fecapentaenes are mutagenic when tested as individual compounds, and to elucidate their exact structure. Previously, mutagenicity of fecapentaene derivatives has been shown to be associated with the presence of the pentaene-system (11). Based on structural resemblance with mutagenic FP-12 and FP-14 as indicated by their pentaenyl UV absorption spectrum, fecapentaenes FP(10.9) FP(12.2) and FP(19.5) which substantially contribute to total fecapentaene content, are hypothesized to possess genotoxic capacity. Further, it has been suggested on the basis of the comparable levels of mutagenic activity of different fecapentaenes (11) that fecapentaene quantifications can be performed by analysis of total fecapentaene content, instead of FP-12 and FP- 14 concentrations separately. However, for the expression in situ of a genotoxic effect of fecapentaenes, these compounds should migrate out of the bowel lumen, where they are produced, through the mucus layer, into the epithelial cells. In conformity with the unequal stability of FP-12 and FP-14 (48), the accessibility of the target DNA in the colonic epithelial cells might be different for both forms. The isomeric forms of FP-12 and FP-14 may also have different kinetic properties. Therefore, for quantitative estimation of colon cancer risk of these fecal mutagens, we suggest to discriminate between excreted amounts of FP-12, FP-14 and all analogues. Finally, the presence of fecal antimutagens considerably complicates the evaluation of genotoxic risk for the target colonic DNA in case of lumenic exposure to mutagenic agents. In situ, physico-chemical conditions, composition of feces, pharmacokinetic and biotransformational properties of both genotoxic and antimutagenic substances, intracellular oxidation and DNA-repair capacities constitute a very complex matrix of possible interactions, which has to be thoroughly understood before colon cancer risk assessment of fecapentaenes can be reliably performed.

\section{Acknowledgements}

We like to thank Prof. Dr. A. Van der Gen and L.B.J. Vertegaal, Department of Organic Chemistry State University Leiden, for providing synthetic FP-12 as well as the chromatographic conditions in order to identify all-trans fecapentaene- 14 . 


\section{Further studies on the identification of naturally occurring fecapentaene analogues as well as other fecaenes in human feces}

In addition to the results on quantitative analysis and identification of naturally occurring fecapentaenes in human feces as described previously in this chapter, further studies have been performed to characterize fecaene excretion patterns.

We suggested FP(13.2), FP(13.5) and FP(14.0) to be cis/trans isomers of FP-12 based on the facts that:

1) All three components show identical pentaene UV absorption spectra,

2) Synthetic FP-12 coelutes with FP(14.0), and

3) Isomerization has been observed between $\mathrm{FP}(14.0), \mathrm{FP}(13.5)$ and $\mathrm{FP}(13.2)$.

In order to confirm this hypothesis, mass spectrometric analyses have becn performed on these 3 compounds. Fecal dichloromethane extracts of a female volunteer, containing high concentrations of the three suggested FP-12 isomers as confirmed by HPLC-photodiode array analysis, were selected for analysis by LCMS. Stool collection and fecapentaene analysis have been performed using extraction and analytical procedures as described earlier. Analysis was performed on a VG AutoSpec Q mass spectrometer, using electron ionization to generate molecular ions $\left(\mathrm{M}^{+*}\right)$ at $\mathrm{m} / \mathrm{z} 250$. By means of the B/E scan technique, and using helium as a collision gas, the first field free region daughter ion spectra of the $\mathrm{m} / \mathrm{z}$ 250 ions were recorded and found to be identical. These findings show that the $\mathrm{m} / \mathrm{z} 250$ ions generated from the three compound have identical structures, strongly indicating that the neutral molecules are geometrically isomeric. Mass spectrometric analyses are planned in the near future in order to characterize the suggested FP.14 isomers, $F P(17.7)$ and $F P(18.2)$ as well as the additional fecapentaenes FP(10.9), FP(12.2) and FP(19.5).

Apart from the 8 fecapentaene analogues that have been described, incidently peaks have been found with a retention time of 15.0 or 22.9 minutes, also showing the pentaene spectrum. However, in view of their less frequent occurrence $(<5 \%)$ and relatively low levels estimated on equal molecular basis ( $<$ $250 \mu \mathrm{g} / \mathrm{kg}$ wet feces) they appear not to contribute substantially to total fecapentaene excretion levels. Next to the typical pentaene structures, also compounds showing an UV spectrum with two absorption maxima shifted upscale $(360-380 \mathrm{~nm})$ or downscale $(310-330 \mathrm{~nm})$ as compared to the pentaenes, have been found in these human fecal dichloromethane extracts (Figure 5). Peters et al. 

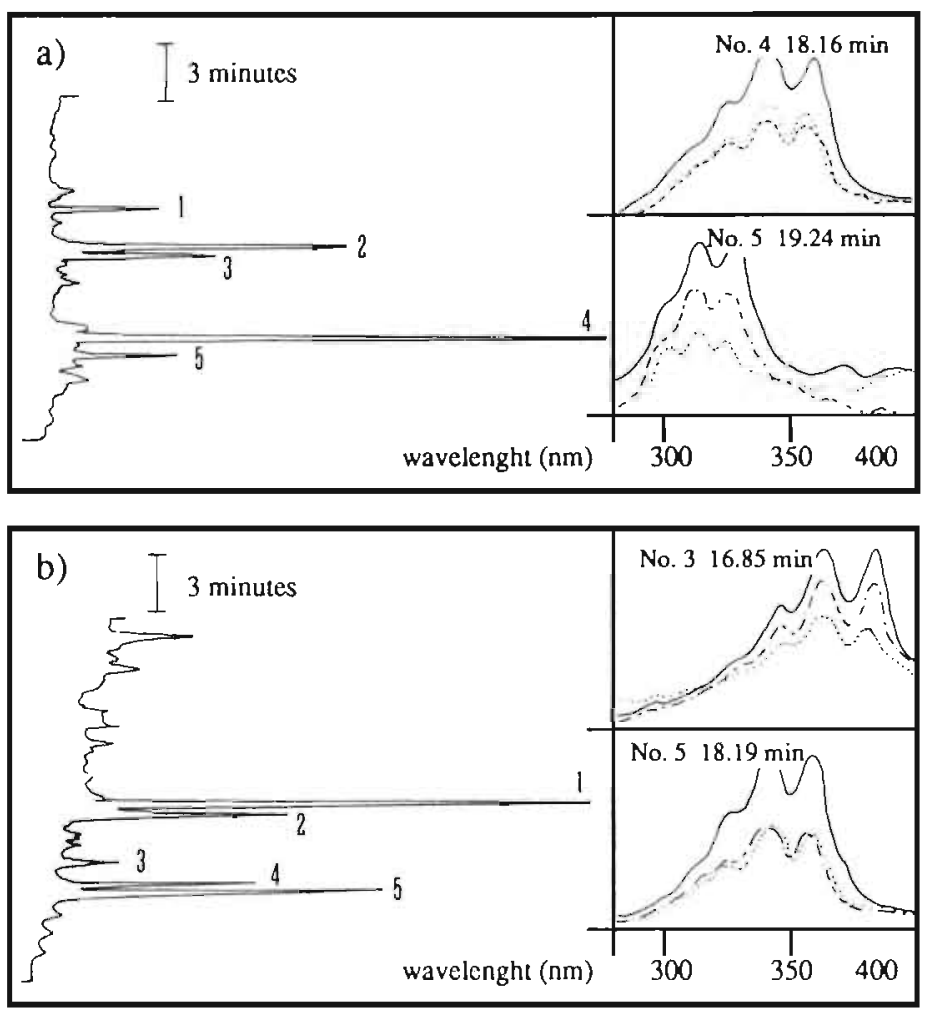

Fig 5: HPLC-chromatogram of a faecal dichloromethane extract containing 4 fecapentaene analogues, all characterized by a typical pentaene absorption spectrum and a) 1 hypothesized fecatetraene showing absorption maxima at 310-330 $\mathrm{nm}$ (compound 5), and b) 1 hypothesized fecahexaene showing absorption maxima at 360-380 nm (compound 3).

(25) first reported the presence of these substances and suggested their structure to be hexaenes (spectrum shifted upscale) or tetraenes (spectrum shifted downscale). In contrast to quantitative data on excretion of fecapentaenes, little is known on the occurrence of other fecaenes. Results of our analyses showed excretion of detectable concentrations of suggested tetraenes at retention times of 15.4 and 19.2 minutes in $31 \%$ of the research population (Table IV). Fecahexaenes have been found in only $5 \%$ of these samples. Since no synthetic fecatetraenes and fecahexaenes are commercially available and molar extinction coefficients are unknown it is impossible to calculate absolute concentrations.

Analysis of the mutagenic potential of synthetic fecaenes revealed that both fecahexaene-14 and fecatetraene-10 are less mutagenic to Salmonella typhimurium TA 100 as compared to synthetic FP-12 (49). Further data on both in vitro and in vivo mutagenic and carcinogenic effects of fecatetraenes and fecahexaenes are required in order to establish their contribution to total fecaene genotoxicity. 
Table IV.: Occurrence of hypothesized fecatetraenes and fecahexaenes in dichloromethane extracts of faeces from 54 individuals, quantified in $\mathrm{mAU}$ at $310 \mathrm{~nm}$.

\begin{tabular}{lrll}
\hline & occurrence $(\%)$ & median value in mAU* & $\mathrm{N}$ \\
\hline fecatetraenes & 31 & $7.2(3.2 ; 22.3)^{* *}$ & 19 \\
fecahexaenes & 5 & 12.1 & 3 \\
\hline
\end{tabular}

*Compared to $10 \mathrm{mAU}$ for $347.2 \mu \mathrm{g} \mathrm{FP}-12 / \mathrm{kg}$ wet faeces (at $335 \mathrm{~nm}$ ).

$* *\left(10^{\text {th }} ; 90^{\text {th }}\right.$ percentiles $)$

\section{References}

1. Bruce, W.R., Varghese, A.J., Furrer, R. and Land, P.C. (1977): A mutagen in the feces of normal humans. In: Origins of Human Cancer, pp 1641-1644 Editors : H.H. Hiatt, J.D. Watson and J.A. Winston. Cold Spring Harbor Laboratory, Cold Spring Harbor, NY.

2. Bruce, W.R., Baptista, J., Che, T., Furrer, R., Gingerich, J.S., Gupta, I. and Krepinsky, J.J. (1982): General structure of "fecapentaenes" the mutagenic substances in human faeces. Naturwissenschaften 69, 557-558.

3. Hirai, N., Kingston, D.G., Van Tassell, R.L. and Wilkins, T.D. (1985): Isolation and structure elucidation of fecapentaenes-12, potent mutagens from human feces. J. Nar. Prod. 4, 622-630.

4. Gupta, I., Baptista, J., Bruce, W.R., Che, C.T., Furrer, R., Gingerich, J.S., Grey, A.A., Marai, L., Yates, P. and Krepinsky, J.J. (1983): Structures of fecapentaenes, the mutagens of bacterial origin isolated from human feces. Biochemistry 22, 241 245.

5. Gupta, I., Suzuki, K., Bruce, W.R., Krepinsky, J.J. and Yates, P. (1984): A model study of fecapentaenes: mutagens of bacterial origin with alkylating properties. Science 225, $521-523$.

6. Kingston, D.G., Wilkins, T.D., Van Tassell, R.L., MacFarlane, R.D. and McNeal, J. (1981): Structural studies on a mutagenic bacterial product from human feces. Banburry rep. 7, 215-226.

7. Van Tassell, R.L., MacDonald, D.K. and Wilkins, T.D. (1982): Production of a fecal mutagen by Bacteroides spp. Infection and Immunity 3, 975-980.

8. Van Tassell, R.L., Schram, R.M. and Wilkins, T.D. (1986): Microbial biosynthesis of fecapentaenes. In: Genetic toxicology of the diet, pp 199-211. Editor: Alan R. Liss, Inc.

9. Lederman, M., Van Tassell, R.L., West, S.E., Ehrich, M.F. and Wilkins, T.D. (1980): In vitro production of human fecal mutagen. Mutat. Res. 79, 115-124.

10. Curren, R.D., Putman, D.L., Yang, L.L., Haworth, S.R., Lawlor,T.E., Plummer, S.M. and Harris, C.C. (1987): Genotoxicity of fecapentaene-12 in bacterial and mammalian cell assay systems. Carcinogenesis 8, 349-352.

11. Peters, J.H., Riccio, E.S., Stewart, K.R. and Reist E.J. (1988): Mutagenic activities of fecapentaene derivatives in the Ames/Salmonella test system. Cancer Lett. 39, $287-$ 296. 
12. Göggelmann, W., Maier, F.K. and Pfaendler, H.R. (1986): Mutagenicity of synthetic racemic fecapentaene-12. Mutat.. Res. 174, 165-167.

13. Dypbukt, J.M., Edman, C.C., Sundqvist, K., Kakefuda, T., Plummer, S.M., Harris, C.C., Grafström, R.C. (1989): Reactivity of fecapentaene- 12 toward thiols, DNA, and these constituents in human fibroblasts. Cancer Res. 49, 6058-6063.

14. Plummer, S.M., Grafstrom, R.C., Yang, L.L., Curren, R.D., Linnainmaa, K. and Harris C.C. (1986): Fecapentaene- 12 causes DNA damage and mutations in human cells. Carcinogenesis 7, 1606-1609.

15. Weston, A., Plummer, S.M., Grafstrom, R.C., Trump, B.F. and Harris C.C. (1986): Genotoxicity of chemical and Physical agents in cultured human tissues and cells. Fd. Chem. Toxic. 6/7, 675-679.

16. Schmid, E., Bauchinger, M., Braselmann, H., Pfaendler, H.R. and Göggelmann, W. (1987): Dose-response relationship for chromosome aberrations induce by fecapentaene-12 in human lymphocytes. Mutat Res. 191, 5-7.

17. Hinzman, M.J., Novotny, C., Ullah, A. and Shamsuddin, A.M. (1987): Fecal mulagen fecapentaene-12 damages mammalian colon epithelial DNA. Carcinogenesis 8, 1475-1479.

18. Ward, J.M., Anjo, T., Ohannesian, L., Keefer, L.K., Devor, D.E., Donovan, P.J., Smith, G.T., Henneman, J.R., Streeter, A.J., Konishi, N., Rehm, S., Reist, E.J., Bradford, W.W. and Rice, J.M. (1988): Inactivity of fecapentaene-12 as a rodent catrcinogen or tumor initiator. Cancer Lett. 42, 49-59.

19. Vaughan, D.J., Furter, R., Baptista, J. and Krepinsky, J.J. (1987): The effect of fecapentaenes on nuclear aberrations in murine colonic epithelial cells. Cancer Lett. 37, 199-203.

20. Weisburger, J.H., Jones, R.C., Wang, C.X., Backlund, J.Y.C., Williams, G.M., Kingston, D.G.I., Van Tassell, R.L., Keyes, R.F., Wilkins, T.D., de Wit, P.P., van der Stceg, M. and van der Gen, A.(1990): Carcinogenicity tests of fecapentaene-12 in mice and rats. Cancer Lett. 49, 89-98.

21. Schiftman, M.H., Van Tassell, R.L., Robinson, A., Smith, L., Daniel, J., Hoover, R.N., Weil, R., Rosenthal, J., Nair, P.P., Schwartz, S., Pettigrew, H., Curale, S., Batist, G., Block, G. and Wilkins, T.D. (1989): Case-Control study of colorectal cancer and fecapentaene excretion. Cancer Res. 49, 1322-1326.

22. Sichilman, M.H. (1987): Dict and faecal genotoxicity. Cancer Surveys 6 653-672.

23. Baptista, J., Bruce, W.R., Gupta, I., Krepinsky, J.J., Van Tassell, R.L. and Wilkins T.D. (1984): On distribution of different fecapentaenes, the fecal mutagens, in the human population. Cancer Lett. 22, 299-303.

24. Bruce, W.R., Varghese, A.J., Land, P.C. and Krepinsky, J.J. (1981): Properties of a mutagen isolated from feces. Banburry Rep. 7, 227-234.

25. Peters, J.H., Nolen, H.W., Gordon, G.R., Bradford, W.W., Bupp, J.E. and Reist, E.J. (1989): Combined chromatographic-isotopic dilution analysis of fecapentaenes in human feces. J. Chromatogr. 488, $301-313$.

26. Block, H.B., Dietrich, M.F., Leake, R., Laidlaw, S.A., Vinton, N.E. and Kopple, J.D. (1990): Fecapentaene excretion: aspects of excretion in newborn infants, children and adult normal subjects and in adults maintained on total parenteral nutrition. Am.J. Clin. Nurr. 51, 698-704.

27. Kleinjans, J.C., Pluijmen, M.H., Hageman, G.J. and Verhagen, H. (1989): Stabilization and quantitative analysis of fecapentaenes in human feces, using syntheric fecapentaene-12. Cuncer Letl. 44, 33-37. 
28. De Wit, P.P., Van Schaik, T.A., and Van der Gen, A. (1984): A convenient synthesis of fecapentaene-12 by the Horner-Witting reaction. Recl. Trav. Chim. Pays-Bas, $103,369-370$.

29. Maron, D.M. and Ames, B.N. (1983): Revised methods for the Salmonella mutagenicity test. Mutat. Res. 113, 173-215.

30. Hageman, G., Kikken, R., Ten Hoor, F. and Kleinjans, J. (1988): Assessment of mutagenic activity of repeatedly used deep-frying fats. Mutar. Res. 204, 593-604.

31. Wilkins, T.D., Lederman, M., Van Tassell, R.L., Kingston, D.G. and Henion, J. (1980): Characterization of mutagenic bacterial product in human feces. Am. J. Clin. Nutr. 33, 2513-2520.

32. Van Tassell, R.L., MacDonald, D.K. and Wilkins, T.D. (1982): Stimulation of mutagen production in human feces by bile and bile acids. Mutat Res. 103, 233-239.

33. Taylor, P.R., Schiffman, M.H., Jones, D.Y., Judd, J., Schatzkin,A., Nair, P.P., Van Tassell, R.L. and Block, G. (1988): Relation of changes in amount and type of dietary fat to fecapentaenes in premenopausal women. Mutat. Res. 206, 3-9.

34. Schiffman, M.H., Van Tassell, R.L., Andrews, A.W., Wacholder, S., Daniel, J., Robinson, A., Smith, L., Nair, P.P. and Wilkins T.D. (1989): Fecapentaene concentration and mutagenicity in 718 North American stool samples. Mutat. Res. 222, 351-357.

35. Schiffman, M.H., Bitterman, P., Viciana, A.L., Schairer, C., Russel, L., Van Tassell, R.L. and Wilkins T.D. (1988): Fecapentaenes and their precursors throughout the bowel- Results of an autopsy study. Mutat. Res. 208, 9-15.

36. Reddy, B.S., Sharma, C., Mathews, L. and Engle, A. (1984): Fecal mutagens from subjects consuming a mixed-western diet. Mutat. Res. 135, 11-19.

37. Van Tassel!, R.L., Piccariello, T., Kingston, D.G., Wilkins, T.D. (1989): The precursors of fecapentaenes: Purification and properties of a novel plasmalogen. Lipids 24, 454-459.

38. Kingston, D.G.I., Piccariello, D.T., Keyes, R.F., Van Tassell, R.L. and Wilkins, T.D. (1989): Isolation and structure elucidation of plasmalopentaene- 12 the biological precursor of fecapentaene-12. Tetrahedron Lelt. 30, 6665-6668.

39. Schiffman, M.H., Andrews, A.W., Van Tassell, R.L., Smith, L., Daniel, J., Robinson, A., Hoover, R.N., Rosenthal, J. Weil, R., Nair, P.P., Schwartz, S., Pettigrew, H., Batist, G., Shaw, R. and Wilkins, T.D. (1989): Case-control study of colorectal cancer and fecal mutagenicity. Cancer Res. 49, 3420-3424.

40. Venitt, S. (1988): Mutagens in human faeces and cancer of the large bowel. In: $G u t$ Flora in Toxicology and Cancer, pp. 399-460, Editor: 1. Rowland, Academic Press, London.

41. Reddy, B.S., Sharma, C. and Wynder, E. (1980): Fecal factors witch modify the formation of fecal co-mutagens in high and low-risk population for colon cancer. Cancer Letr. 10, 123-132.

42. Dion, P.W., Bright-See, E.B., Smith, C.C. and Bruce, W.R. (1982): The effect of dietary ascorbic acid and tocopherol on fecal mutagenicity. Mutat. Res. 102, 27-37.

43. Hayatsu, H., Arimoto, S. Togawa, K. and Makita, M. (1981): Inhibitory effect of the ether extract of human feces on activities of mutagens: inhibition by oleic and linoleic acids. Mutat. Res. 81, 287-293.

44. Mower, H.F., Ichinotsubo, D., Wang, L.W., Mandel, M., Stemmermann, G., Nomura, A., Heilbrum, L., Kamiyama, S. and Shimada A. (1982): Fecal mutagens in two japanese populations with different colon cancer risks. Cancer Res. 42, 1164 1169. 


\section{Chapter 2}

45. De Vet,. H.C.W., Sharma, C., and Reddy, B.S. (1981): Effect of dietary fried meat on fecal mutagenic and co-mutagenic activity in humans. Nutrition Reports International, 4, 653-660.

46. Bruce, W.R. and Dion, P.W. (1980): Studies relating to a fecal mutagen. Am. J. Clin. Nutr. 33, $2511-2512$.

47. Askew, A.R., Ward, M., Green, M.K. and Reiber, O. (1982): Fecal mutagenesis and colonic cancer. Aust. N.J. Surg. 52, 27-29.

48. Krepinsky, J.J. (1988): Formation and biological effects of fecapentaenes. Prog. Biochem. Pharmacol. 22, 35-47.

49. Voogd, C.E., Vertegaal, L.B.J., van der Steeg, M., van der Gen, A. and Mohn, G.R. (1990) Structure, chemical reactivity and in vitro mutagenic activity in a series of fecapentaene analogues. Mutation Res., 243, 195-199. 


\title{
Chapter 3
}

\section{Excretion of different fecapentaene analogues and fecal mutagenicity in relation to nutrient intake and fecal parameters in humans on omnivorous and vegetarian diets}

\author{
T.M.C.M. de Kok, A. van Faassen, R.A. Bausch-Goldbohm, F. ten Hoor \\ and J.C.S. Kleinjans.
}

Based on: Cancer Letl., 62 (1992) 11-21.

\begin{abstract}
Fecapentaenes are strong fecal mutagenic compounds presumably occurring in the majority of Western human individuals, and are possibly essential initiators of colon carcinogenesis. Dietary factors have been shown to influence colorectal cancer risk and to modulate both fecal mutagenicity and fecapentaene concentrations. Therefore, in this study, excretion of fecapentaenes is determined in humans consuming either vegetarian or omnivorous diets. The results show that the most predominant fecapentaene forms are excreted in higher concentrations by vegetarians. Consumption of cereal fiber, calcium and carotene as well as fecal concentrations of iso-lithocholic acid were found to correlate positively with excreted concentrations of one or more fecapentaene analogues. On average, $22 \%$ of excreted fecapentaene concentrations was found to be related to nutrient intake in stepwise regression models. Dietary calcium intake was found to be the most significant factor positively correlating with excreted fecapentaene concentrations. Intake of mono-unsaturated fatty acids or fiber from vegetables and fruit could be shown to correlate with fecapentaene excretion to a lesser degree. Despite high fecapentaene concentrations in fecal dichloromethane extracts, only 1 out of 20 samples revealed significant mutagenic activity in Salmonella typhimurium TA 100. Further, aqueous extracts of feces from omnivore appeared to be as equally mutagenic as feces from vegetarians and contained non-detectable concentrations of fecapentaenes. It is concluded that dietary factors do affect excreted fecapentaene levels, but only to a relatively minor extent. Since vegetarians at low risk for colorectal cancer excrete higher concentrations of fecapentaenes, it could be hypothesized that relatively increased fecapentaene excretion in combination with antimutagenic compounds in feces represents colon cancer prevention.
\end{abstract}




\section{Introduction}

It has been suggested that cancer of the human large bowel may be caused by mutagens or carcinogens present in feces, to which colon and rectum are continuously exposed (1). Fecapentaenes, characterized by a highly unsaturated conjugated enol ether system, form a predominant group of such fecal genotoxins (2-7). Since synthetic fecapentaene-12 (FP-12) shows high mutagenic potential in vitro (8-14) and also induces cytogenetic and carcinogenic effects after intrarectal installation in rats or intraperitoneal injection in newborn mice (15-17), these compounds may be of relevance in colon carcinogenesis. Fecapentaenes originate from anaerobic bacterial production in the colonic lumen, and bile acids are required for their synthesis $(1,18-21)$. Although a direct precursor of fecapentaenes has been described (22-24), the ultimate origin of these mutagens remains to be determined. Since diet is generally considered to be an important risk factor for colorectal cancer and dietary habits have been shown to influence fecal mutagenicity (25-32), it is of interest to investigate the effects of dietary constituents on fecapentaene production $(32,33)$. Using high recovery extraction and an analytical procedure that separates at least eight different fecapentaene analogues (34), we compared fecapentaene concentrations of human stool samples provided by omnivores and vegetarians. Previously, significant differences between these groups have been found for dietary intake of vitamin C, fatty acids, fiber and meat, all factors that have been shown to modulate fecal mutagenicity or fecapentaene levels (25-32). These dietary consumption patterns furthermore, are suggested to present a different risk for colorectal cancer (35). In this study, differences in excreted fecapentaene levels in omnivores and vegetarians are established, and associations between fecapentaenes and dietary as well as fecal parameters are evaluated. Further, mutagenicity of fecal dichloromethane as well as aqueous extracts is determined in Salmonella typhimurium. Also, aqueous extracts are analyzed for fecapentaene extraction recoveries, in order to verify whether previously reported differences in fecal mutagenicity between omnivores and vegetarians $(28.29)$ are caused by different fecapentaene levels.

\section{Materials and methods}

\section{Recruitment of subjects}

Omnivores were drawn from 23 municipalities in The Netherlands. Ovo-lacto vegetarians were recruited by advertisement in the magazine of the Dutch Vegetarian Society. A structured dietary history interview (36) was taken at home and nutrient intake was calculated by using the computerized Dutch Nutrient Databank (37). The groups of omnivores and vegetarians that could be questioned for dietary patterns and produced properly collected stools without urine contamination during 4 consecutive days, finally consisted of 13 and 4 male, and 22 and 10 female subjects respectively. Lag time between dietary survey and stool sampling was approximately 9 weeks. Since al] volunteers were contemporaries aging from 55 to 65 years, no further matching between omnivores and vegetarians was applicd. Additionally, stool samples from 4 male and 6 female vegetarians were included without taking a dietary history. 


\section{Sample collection and storage}

The stool samples were taken at home, in coded plastic bags fitting in a plastic bucket that could be placed into the toilet. Immediately after defecation, the samples were frozen and stored in a styrofoam box with $25 \mathrm{~kg}$ of dry ice. On the fourth day of the sample collection, the box with fecal samples on dry ice was mailed to the laboratory. Stoolweight and fecal $\mathrm{pH}$ were determined after homogenization (38). Defecation frequency was calculated from the number of stools between $15.00 \mathrm{~h}$ on the first day to $12.00 \mathrm{~h}$ on the fourth day. Feces with urine contamination or samples that had thawed before arrival were excluded from analysis. Until fecapentaene analysis, stool samples were protected from light and stored at $-20^{\circ} \mathrm{C}$ (from 1985 to 1989 ).

\section{Fecapentaene quantification}

Equal amounts of subsequently produced stool samples (maximum of 7 per person) were combined and homogenized for fecapentaene analysis. This way of pooling results in an averaged exposure concentration at colon/rectum level rather than in absolute fecapentaene excretion. In 8 cases, only one stool sample was available. Four grams of wet feces were freeze-dried and extracted twice with $2.5 \mathrm{ml}$ dichloromethane, which was stabilized by $5 \%$ tri-ethylamine (TEA) (39). After evaporation under nitrogen, fecal extracts were resolved in di-ethylether and purified on silica. Finally, eluates were evaporated again, resolved in methanol/TEA ( $99.5: 0.5$ ) and stored at $-20^{\circ} \mathrm{C}$. HPLC-analysis was performed on a spherisorb S5 ODS-2 column with binary gradient elution, using two eluents composed of methanol, acetonitrile, water and tetrahydrofuran in different concentrations. Photodiode array detection was used for peak identification. $\mathrm{FP}(13.2), \mathrm{FP}(13.5)$ and $\mathrm{FP}(14.0)$ represent forms of $\mathrm{FP}-12$ whereas $\mathrm{FP}(17.7)$ and FP(18.2) presumably are isomeric analogues of FP-14. Based on their UV spectrum FP(10.9), FP(12.2) and FP(19.5) are suggested to represent fecapentaene analogues as well, although their chemical structure remains to be determined (34). Stool samples were extracted in triplicate and analyzed twice. Details on fecapentaene analysis have been described previously (34). Aqueous extracts of feces from omnivores have previously been shown to possess higher mutagenic potential in relation to dietary factors $(28,29)$ In order to establish whether this can be contributed to differences in fecapentaene levels, fecapentaene recovery was determined in aqueous extracts obtained according to the procedures of Kuhnlein et al. (28). Therefore, three fecapentaene-free fecal samples were spiked with synthetic FP-12 (provided by Prof. A. van der Gen, University of Leiden, The Netherlands), and 4 grams of wet feces were mixed vigorously for 2 minutes with 4 $\mathrm{ml}$ of milli Q water using an ultra turrax blender. Subsequently, homogenates were centrifuged for $50 \mathrm{~min}$ at $150000 \mathrm{~g}$. Supernatants were evaporated under vacuum until complete dryness and resolved in di-ethylether. Purification and analysis were performed identically as described for dichloromethane extracts.

\section{Mutagenicity testing}

Mulagenicity of dichloromethane and aqueous extracts of feces from 10 randomly selected omnivores and 10 vegetarians was determined using the Salmonella mutagenicity assay according to Maron and Ames (40). Tester strain TA 100 was used without addition of a metabolic activation system (34). Identical extraction 


\section{Chapter 3}

siamples were used in the mutagenicity test as in HPLC analysis. After dichloromethane extraction, 0.5 gram of feces equivalents were introduced per plate in a test volume of $100 \mu \mathrm{l}$. Aqueous extracts were prepared as indicated above and sterilized by passage through 0.45 and $0.2 \mu \mathrm{m}$ poresize millex filters (Millipore BV, Etten-Leur, The Netherlands). These extracts were tested in concentrations of $3 \mathrm{mg}$ feces equivalents per plate, comparable to concentrations used previously in the fluctuation assay $(28,29)$. Additionally, 50 and $200 \mathrm{mg}$ feces equivalents per plate were determined. All fecal samples were extracted and assayed for mutagenicity in triplicate.

\section{Bile acids}

Since bile acids have been shown to be an important cofactor in fecapentaene synthesis (20), total bile acids were determined by gas-liquid chromatography using petroleum ether and di-ethylether extractions of freeze dried feces. Fecal samples were pooled in the same way as described for fecapentaene quantification. Analyses of lithocholic, isolithocholic, deoxycholic, cholic chenodeoxycholic and ursodeoxycholic acid were performed on 20 randomly selected omnivore and all vegetarian stool samples. Analytical details were according to methods described by Glatz et al. (41).

\section{Fecapentaene stability}

Since stool samples were stored at $-20^{\circ} \mathrm{C}$ over a longer period we determined fecapentaene stability at $-20^{\circ} \mathrm{C}$ over a period of two years in feces of 5 subjects. One sample was analyzed for individual fecapentaene contents immediately after defecation, whereas the remaining material was divided in several parts and stored at $-20{ }^{\circ} \mathrm{C}$. At regular time intervals, these samples were analyzed to determine fecapentaene stability in a fecal matrix. No significant changes in fecapentaene concentrations were found except for a $15 \%$ decrease of concentration of $\operatorname{FP}(17.7)$, which indicates that prolonged storage of fecal samples under these specific conditions is appropriate. The indication that FP-12 is more stabile than generally believed, has also been recently reported by Shamsuddin et al. (42).

\section{Statistical methods}

Unpaired t-test was applied for comparison of nutrient intake in omnivores and vegetarians. Since fecapentaene concentrations appeared to be not normally distributed, the Mann-Whitney non-parametric two-sample test was used for comparison of unpaired samples. Spearman rank correlation coefficients were determined between consumption of dietary constituents and excreted fecapentaene concentrations. Stepwise multiple regression analysis was performed on logarithmically transformed fecapentaene concentrations and dietary variables. In the first of two regression models, the forward selection procedure selects only significant variables starting with the highest partial correlation. In a second regression model, sex, omnivore or vegetarian dietary habits and energy intake were additionally forced into the equation. With the inclusion of each new variable in the model, all variables previously entered were re-evaluated. The method of least significant differences (LSD) was used to evaluated mutagenicity data (43). The LSD values were determined at 63 and 139 at a confidence levels of respectively $\mathrm{P}<0.01$ and $\mathrm{P}<0.001$. 


\section{Results}

Nutrient intake and fecal parameters

A comparison of nutrient intake is made between both groups of omnivores and vegetarians. The results in Table I show that significant differences are found in the intake of different types of fiber, animal and vegetable protein, vitamin $\mathrm{C}$, saturated and polyunsaturated fats as well as $\mathrm{p} / \mathrm{s}$ ratio. These results indicate a successful selection of two groups representing large differences in habitual nutrient intake. Consumption of vitamin $C$ appears to be remarkably high in both populations. No differences are observed between sexes in the vegetarian population, whereas male omnivores are found to consume significantly greater amounts of total fat, saturated fat, energy and excreted more fecal bulk as compared to female omnivores $\left(\mathrm{n}_{1}=13\right.$; $\mathrm{n}_{2}=21 ; \mathrm{p}<0.05$ ). Further, defecation frequency and fecal bulk appear to be higher in vegetarians.

Table I. Nutrient intake/day and fecal parameters of omnivores and vegetarians.

\begin{tabular}{|c|c|c|c|c|c|c|}
\hline \multirow[t]{2}{*}{ nutrient } & & \multicolumn{2}{|c|}{ omnivores $(n=35)$} & \multicolumn{2}{|c|}{ vegetarians $(n=14)$} & \multirow[t]{2}{*}{$\mathrm{p}^{*}$} \\
\hline & & mean & S.D. & mean & S.D. & \\
\hline energy & $(\mathrm{KJ})$ & 9378 & 2590 & 8794 & 1777 & ns \\
\hline total fat & $(\mathrm{g})$ & 94.4 & 10.0 & 84.4 & 23.3 & $\mathrm{~ns}$ \\
\hline saturated fat & (g) & 42.8 & 15.1 & 31.0 & 14.1 & 0.02 \\
\hline mono unsaturated fat & (g) & 34.0 & 11.8 & 29.7 & 9.2 & ns \\
\hline poly unsaturated fat & (g) & 15.2 & 6.7 & 20.9 & 7.0 & 0.03 \\
\hline $\mathrm{p} / \mathrm{s}$ ralio & & 0.37 & 0.03 & 0.92 & 0.2 & $<0.01$ \\
\hline total fiber & $(\mathrm{g})$ & 26.9 & 5.6 & 41.9 & 10.9 & $<0.01$ \\
\hline cereal fiber & (g) & 11.0 & 4.3 & 18.2 & 5.6 & $<0.01$ \\
\hline vegetable/fruit fiber & (g) & 15.2 & 5.6 & 23.2 & 9.1 & $<0.01$ \\
\hline total protein & (g) & 81.0 & 19.0 & 64.0 & 17.3 & 0.02 \\
\hline animal protein & (g) & 55.0 & 15.9 & 27.9 & 16.2 & $<0.01$ \\
\hline vegetable protein & $(g)$ & 25.9 & 5.9 & 36.6 & 7.0 & $<0.01$ \\
\hline total carbohydrates & (g) & 245 & 64.7 & 262 & 65.0 & $\mathrm{~ns}$ \\
\hline mono- + disaccharides & $(\mathrm{g})$ & 118 & 44.1 & 110 & 30.4 & ns \\
\hline polysaccharides & (g) & 123 & 32.1 & 139 & 38.7 & ns \\
\hline retinol & $(\mathrm{mg})$ & 1.31 & 0.11 & 0.99 & 0.09 & ns \\
\hline vitamin $\mathrm{C}$ & $(\mathrm{mg})$ & 113 & 47.7 & 163 & 91.5 & 0.02 \\
\hline calcium & $(\mathrm{mg})$ & 1042 & 363 & 1165 & 459 & ns \\
\hline \multicolumn{2}{|l|}{ fecal parameters } & \multicolumn{2}{|c|}{$(n=35)$} & \multicolumn{2}{|c|}{$(n=24)$} & \\
\hline fecal pH & & 6.8 & 0.31 & 6.8 & 0.41 & $\mathrm{~ns}$ \\
\hline fecal bulk & (g/day) & 121.7 & 54.5 & 187.5 & 67.5 & $<0.01$ \\
\hline defecation frequency (ti & imes/day) & 0.94 & 0.34 & 1.463 & 0.52 & $<0.01$ \\
\hline fecal dry weight & $(\%)$ & 25.9 & 7.27 & 26.7 & 7.07 & ns \\
\hline
\end{tabular}

* t-test comparison of various dietary constituents and fecal parameters. 


\section{Fecapentaene quantification}

Concentrations of fecapentaenes as excreted by omnivores and vegetarians and extracted with dichloromethane are presented in Figure I. Fecapentaenes are excreted in higher concentrations by vegetarians as compared to omnivores. The differences are statistically significant for FP(14.0), FP(17.7), FP(18.2) and for total fecapentacnes. Although both fecapentaene concentrations and fecal bulk are found to be higher in vegetarians, differences in fecapentaene excretion per day, calculated from these two factors, are at the same statistical level. When expressed in $\mu \mathrm{g} / \mathrm{kg}$ dry feces, differences in fecapentaene concentrations are less pronounced but remain statistically significant. Excreted levels of FP(13.5), FP(10.9), FP(12.2), FP(13.2) and FP(19.5) appear not to differ significantly between both groups. Undetectable levels, below $5 \mu \mathrm{g} / \mathrm{kg}$ wet feces, are found for $\operatorname{FP}(10.9), \operatorname{FP}(12.2)$, $\mathrm{FP}(13.2)$ and $\mathrm{FP}(19.5)$ in respectively $64 \%, 51 \%, 43 \%$ and $47 \%$ of all samples $(\mathrm{N}=59)$. The median concentration of $\mathrm{FP}(10.9)$ is found to be below $5 \mu \mathrm{g} / \mathrm{kg}$ wet feces for both omnivores and vegetarians, with a concentration range from 5 to 514 and from 5 to 196 respectively. Also the median concentration of FP(12.2) in feces from vegetarians is at the detection limit, and ranges from 5 to $871 \mu \mathrm{g} / \mathrm{kg}$ wet feces. Further, differences in fecapentaene levels between sexes are not statistically significant. No FP-12 is found in aqueous extracts of spiked fecal samples.

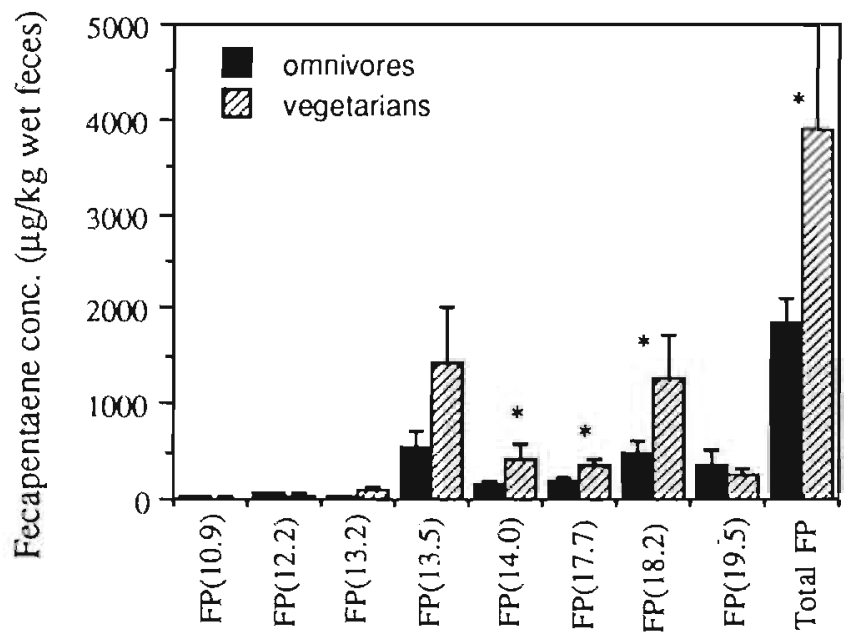

Fecapentaene analogues

Fig 1: Comparison of fecapentaene concentrations as excreted by omnivores and vegetarians (median values). $10^{\text {th }} / 90^{\text {th }}$ percentiles for onmivores and vegctarians are respectuvcly: $\mathrm{FP}(10.9): 0 / 232$ and $0 / 68: \mathrm{FP}(12.2): 0 / 455$ and $0 / 45 ; \mathrm{FP}(13.2): 0 / 455$ and $0 / 274$; FP(13.5): $34 / 1245$ and 29/6434; $\mathrm{FP}(14.0): 13 / 376$ and $14 / 1745 ; \mathrm{FP}(17.7): 23 / 277$ and 55/1058; FP(18.2): $32 / 1054$ and 107/62 10; $\mathrm{FP}(19.5): 0 / 313$ and 0/170; total FP: $194 / 4025$ and $425 / 14312$ $\mu \mathrm{g} / \mathrm{kg}$ wel feces. * indicates a significanı difference $\left(\mathrm{n}_{1}=35, \mathrm{n}_{2}=24, \mathrm{p}<0.05\right)$. 


\section{Associations between fecapentaenes and dietary and fecal parameters}

Correlation coefficients between fecapentaene levels and daily intake of nutrients or fecal parameters are given in Table II. The intake of calcium appears to correlate positively with concentrations of total fecapentaenes and FP(19.5). Further, intake of cereal fiber is found to correlate positively with concentrations of total fecapentaenes, FP(17.7) and FP(18.2). Marginal statistic reliability is found for correlations between decreased vitamin-C consumption and $\mathrm{FP}(18.2)$ and total fecapentaenes, between intake of calcium and elevated levels of FP(13.5). Furthermore, marginal statistic reliability is found for $\mathrm{p} / \mathrm{s}$ ratio relating positively to FP(17.7) and saturated fat consumption relating negatively. The statistical reliability of these correlations is slightly improved when fecapentaene levels are expressed in $\mu \mathrm{g} / \mathrm{kg}$ dry feces.

Positive associations between fecapentaene levels and fecal parameters are found for defecation frequency and FP(14.0), and for iso-lithocholic acid and FP(13.5) and $\mathrm{FP}(14.0)$. Further, none of the total bile acids is found to correlate significantly to one of the dietary items from Table I.

After logarithmic transformation, fecapentaene concentrations appear to be normally distributed, and stepwise multiple regression analysis can be performed. Of all dietary variables indicated in Table I, total fat, total fiber, total protein and total carbohydrates are not included in this analysis. The results from these calculations, given in Table III, indicate that dietary intake of calcium, fiber and mono-unsaturated fatty acids represent the most relevant factors in relation to fecapentaene excretion. Effects of partial correlations between dietary factors and energy intake can be corrected by forcing this variable into the regression model. In

Table II. Associations between dietary and fecal parameters and fecapentaene levels.

$\begin{array}{llllll}\text { total FP } & \mathrm{FP}(13.5) & \mathrm{FP}(14.0) & \mathrm{FP}(17.7) & \mathrm{FP}(18.2) & \mathrm{FP}(19.5)\end{array}$

\begin{tabular}{lllllll}
\hline calcium & $0.31^{\mathrm{a}}$ & $0.24^{\mathrm{b}}$ & $0.22^{\mathrm{c}}$ & $0.17^{\mathrm{c}}$ & $0.17^{\mathrm{c}}$ & $0.35^{\mathrm{a}}$ \\
cereal fiber & $0.30^{\mathrm{a}}$ & $0.23^{\mathrm{c}}$ & $0.23^{\mathrm{c}}$ & $0.35^{\mathrm{a}}$ & $0.31^{\mathrm{a}}$ & $0.02^{\mathrm{c}}$ \\
saturated fat & $-0.19^{\mathrm{c}}$ & $-0.16^{\mathrm{c}}$ & $-0.15^{\mathrm{c}}$ & $-0.26^{\mathrm{b}}$ & $-0.15^{\mathrm{c}}$ & $-0.02^{\mathrm{c}}$ \\
p/s ratio & $0.10^{\mathrm{c}}$ & $0.10^{\mathrm{c}}$ & $0.07^{\mathrm{c}}$ & $0.24^{\mathrm{b}}$ & $0.05^{\mathrm{c}}$ & $-0.02^{\mathrm{c}}$ \\
vitamin C & $-0.24^{\mathrm{b}}$ & $0.04^{\mathrm{c}}$ & $-0.09^{\mathrm{c}}$ & $-0.06^{\mathrm{c}}$ & $-0.26^{\mathrm{b}}$ & $-0.06^{\mathrm{c}}$ \\
retinol & $-0.23^{\mathrm{c}}$ & $-0.14^{\mathrm{c}}$ & $-0.17^{\mathrm{c}}$ & $-0.31^{\mathrm{a}}$ & $-0.18^{\mathrm{c}}$ & $-0.05^{\mathrm{c}}$ \\
& & & & & & \\
defecation frequency & $0.25^{\mathrm{b}}$ & $0.15^{\mathrm{c}}$ & $0.33^{\mathrm{a}}$ & $0.18^{\mathrm{c}}$ & $0.21^{\mathrm{c}}$ & $0.02^{\mathrm{c}}$ \\
iso-lithocholic acid & $0.26^{\mathrm{b}}$ & $0.35^{\mathrm{a}}$ & $0.30^{\mathrm{a}}$ & $0.10^{\mathrm{c}}$ & $-0.04^{\mathrm{c}}$ & $0.29 \mathrm{~b}$
\end{tabular}

Spearman correlation coefficients between fecapentaene concentrations in wet feces and nutrient intake and fecal parameters. Factors not correlating to fecapentaene concentrations are omitted. No factors were found to correlate significantly to fecal concentrations of $\mathrm{FP}(10.9), \mathrm{FP}(12.2)$ and $\mathrm{FP}(13.2)$. a: significant at $\mathrm{p}<0.05$; $\mathrm{b}$ : marginal significant, $0.05<\mathrm{p}$ $<0.10$; ${ }^{\mathrm{C}}$ not significant, $\mathrm{p}>0.10$. 
Table III. Stepwise regression analysis on logarithmic transformed fecapentaene concentrations and nutrients.

\begin{tabular}{|c|c|c|c|c|c|c|}
\hline \multirow[t]{2}{*}{ fecapentaene } & \multicolumn{3}{|c|}{$\begin{array}{l}\text { regression model } 1 \\
\text { no variables forced into the } \\
\text { regression model }\end{array}$} & \multicolumn{3}{|c|}{$\begin{array}{l}\text { regression model } 2 \\
\text { sex, omnivore/vegetarian and } \\
\text { energy intake included }\end{array}$} \\
\hline & & B & SE & & B & SE \\
\hline \multirow[t]{2}{*}{ Total FP } & calcium & 5.1 & 1.4 & calcium & 5.0 & 1.5 \\
\hline & $\begin{array}{l}\text { monounsat. fat } \\
\mathrm{R}^{2}=0.29\end{array}$ & -133.7 & 46.9 & $\begin{array}{l}\text { vegetable/fruit fiber } \\
\mathrm{R}^{2}=0.34\end{array}$ & 195.6 & 88.9 \\
\hline \multirow[t]{2}{*}{$\mathrm{FP}(13.5)$} & calcium & 2.5 & 0.8 & calcium & 0.07 & 0.02 \\
\hline & $\begin{array}{l}\text { monounsat. fat } \\
\mathrm{R}^{2}=0.22\end{array}$ & -59.1 & 26.7 & $\mathrm{R}^{2}=0.20$ & & \\
\hline \multirow[t]{2}{*}{$\operatorname{FP}(14.0)$} & calcium & 0.5 & 0.2 & calcium & 0.5 & 0.2 \\
\hline & $\begin{array}{l}\text { monounsat. fat } \\
\mathrm{R}^{2}=0.18\end{array}$ & -12.0 & 5.9 & $\mathrm{R}^{2}=0.17$ & & \\
\hline \multirow[t]{2}{*}{$\mathrm{FP}(17.7)$} & - & & & cereal fiber & 3.5 & 1.4 \\
\hline & & & & $\begin{array}{l}\text { retinol } \\
\mathrm{R}^{2}=0.30\end{array}$ & -0.2 & 0.1 \\
\hline \multirow[t]{2}{*}{$\mathrm{FP}(18.2)$} & calcium & 1.5 & 0.5 & monounsat. fat & -100.1 & 40.2 \\
\hline & $\begin{array}{l}\text { monounsat. fat } \\
\mathrm{R}^{2}=0.20\end{array}$ & -43.6 & 18.3 & $\begin{array}{l}\text { vegetable/fruit fiber } \\
\mathrm{R}^{2}=0.29\end{array}$ & 82.2 & 34.2 \\
\hline
\end{tabular}

Regression coefficients (B) and standard error (SE) of variables that are entered into stepwise regression models.

this case, calcium accounts for 20 and $17 \%$ of the total variation in concentrations of respectively $\mathrm{FP}(13.5)$ and $\mathrm{FP}(14.0)$, and together with fiber from vegetables and fruit for $34 \%$ in total fecapentaene excretion. Stepwise regression analysis with regard to other individual fecapentaene analogues reveals that intake of monounsaturated fatty acids and fiber from vegetables and fruit are significantly related to excretion of FP(18.2), whereas concentrations of FP(17.7) are partially influenced by intake of cereal fiber and retinol. None of the variables is found to be significantly related to FP(10.4), FP(12.2), FP(13.2) and FP(19.5).

\section{Mutagenicity testing}

Maximal mutagenic effect of synthetic FP-12 is found at a concentration of 1 $\mu \mathrm{g} /$ plate, whereas at a concentration of $2 \mu \mathrm{g} /$ plate the number of revertants is reduced from 1100 to 200 due to cytotoxic effects. Although both individual and total fecapentaene concentrations are within the mutagenic range, revertant scores induced by all other extracts do not exceed the number of spontaneous revertants in the solvent control ( $=90$ revertants/plate; Figure 2 ). Only one fecal extract of a male vegetarian containing a rather extreme concentration of $125 \mu \mathrm{g} / \mathrm{ml}(=25 \mathrm{mg}$ of total fecapentaenes per $\mathrm{kg}$ wet feces), shows significant mutagenicity. This extract results in a fecapentaene concentration of $12.5 \mu \mathrm{g} / \mathrm{plate}$, which in purified form is 
Fig. 2: Relation between fecal mutagenicity and total fecapentaene concentrations in fecal dichloromethane (DCM) exctracts of omnivorous and vegetarian donors in $S$.

typhimurium TA 100 , in comparison to the mutagenic potential of synthe-tic FP12. Number of spontaneous revertants $=90$.

Fig 3: Mutagenicity to $S$. typhimurium TA 100 of aqueous extracts of stools from omnivores and vegetarians in relation to fecapentaene concen-trations in fecal dichloromethane extracts. All plates contain $200 \mathrm{mg}$ feces equivalents / plate.
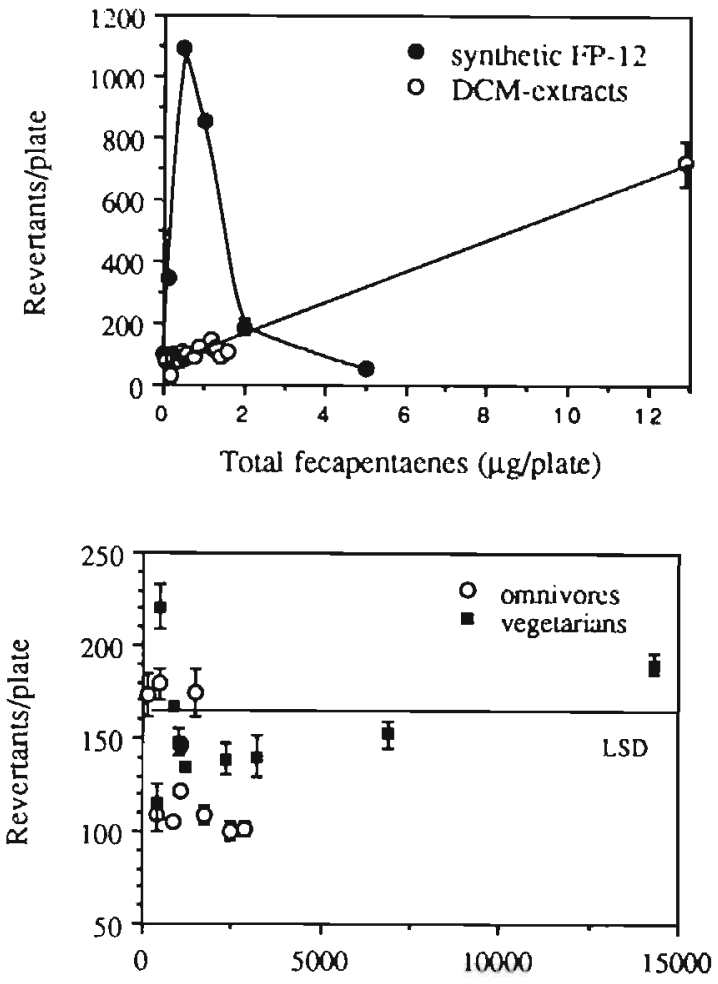

Fecapentacne concentration $(\mu \mathrm{g} / \mathrm{kg}$ wel foces)

extremely cytotoxic to Salmonella. Apart from an unidentified factor that effectively inhibits the expression of fecapentaene mutagenicity, apparently also cytotoxicity blocking activity can be present in fecal dichloromethane extracts. Mutagenicity of aqueous extracts in concentrations of $200 \mathrm{mg}$ feces equivalents per plate, appears not to correlate with fecapentaene concentrations in fecal dichloromethane extracts (Figure 3). Further, fecal extracts of three omnivores and of three vegetarians exceed the LSD-value. Using the Mann-Whitney U-test, no significant difference in mutagenicity is found between feces from omnivores and vegetarians (mean ranks: omnivore $=8.1$; vegetarian $=12.1, Z=1.552, p>0.05$ )

\section{Discussion}

Analysis of fecapentaenes in stools of humans on omnivorous and vegetarian diets has shown that the most predominant fecapentaene forms are excreted in higher concentrations by vegetarians as compared to omnivores. Total fecapentaene excretion appears to be twice as high in vegetarians. Also for individual fecapentaenes FP(14.0), FP(17.7) and FP(18.2) differences in fecal concentrations are statistically significant. 
Although fecapentaene analysis has not been compared for vegetarians and omnivores previously, vegetarians have been suggested to excrete less of these fecal mutagens. This hypothesis is based upon mutagenicity results from dietary studies and the fact that vegetarians are at relatively low risk for colorectal cancer. Kuhnlein et al. (28) showed that fecal mutagenicity of aqueous extracts to $S$. typhimurium TA 100 is lower in vegetarians than in non-vegetarians. Similar results have also been found using different extraction procedures and mutagenicity assays $(25,29,44,45)$. Further, fecal mutagenicity has been found to be lowered by intake of ascorbic acid, tocopherol and fiber, dietary factors that are generally consumed in higher amounts by vegetarians $(18,26,46,47)$. Additionally, various populations at low risk for colorectal cancer have been demonstrated to excrete less mutagenic feces $(30,45,48-50)$. However, we found that no difference in fecal mutagenicity after dichloromethane extraction between these dietary groups appeared to exist. Only one out of $20 \mathrm{fecal}$ dichloromethane extracts appeared to be mutagenic to $S$. typhimurium TA 100 , although total fecapentaene concentrations in these samples should be high enough to induce several hundreds of revertants per plate. Furthermore, fecapentaenes appear to be absent in aqueous extracts, indicating that the reported mutagenic potential in these extracts $(28,29)$ has to be attributed to mutagens other than fecapentaenes. This is confirmed by the absence of a correlation between mutagenicity of aqueous extracts and fecal fecapentaene concentrations.

In addition, it has previously been demonstrated that fecapentaene excretion data do not provide a reliable index for fecal mutagenicity $(34,51)$, possibly caused by the presence of antimulagenic substances such as natural antioxidants.

Despite the fact that both fecapentaene concentrations and intake of a variety of dietary constituents have been found to differ between vegetarians and omnivores, associations between individual dietary parameters and fecapentaene levels are rather weak. Furthermore, in stepwise regression models, the included nutrients are found to correlate to only a minor extent (average 22\%) with fecapentaene concentrations.

Since bile has been shown to be required for fecapentaene synthesis in vitro $(19,20)$, several bile acids have been quantified in the same stool samples analyzed for fecapentaene levels in this study. No correlations have been found between total bile acids and fecapentaene levels and a significant correlation between fecal concentrations of only iso-lithocholic acid and both FP(13.5) and FP(14.0) has been demonstrated. Apparently, bile acids are not a rate limiting factor in fecapentaene production in vivo, and therefore it can not be indicated which bile acids and to what extent are involved in fecapentaene synthesis.

A negative determinant of total fecapentaene concentrations and excreted concentrations of $\mathrm{FP}(13.5), \mathrm{FP}(14.0)$ and $\mathrm{FP}(18.2)$ is the intake of monounsaturated fatty acids. When energy intake is forced into the regression model however, this dietary component appears not to make a significant contribution. Previously, consumption of fatty foods such as butter and margarine has been related to decreased total fecapentaene concentrations in feces (32), but $\mathrm{p} / \mathrm{s}$ ratio appeared of no influence on fecapentaene concentrations (33). Further, it has been reported that supplemental vitamin $\mathrm{C}$, citrus fruits, total dietary carotene and fiber were associated with decreased fecapentaene excretion (32). In contrast, we have found no association with dietary vitamin $\mathrm{C}$, and an inverse correlation between levels of $\mathrm{FP}(17.7)$ and intake of retinol. 
In our analyses, calcium intake appears to be the most significantly correlating dietary factor with respect to fecapentaene levels. In previous research, no association between calcium intake and fecapentaenes has been assessed. However, dietary calcium is generally linked to colon cancer as a protective factor (52). A variety of biological mechanisms have been proposed including direct inhibiting effects of calcium on colonic epithelial cell proliferation and reduction of the exposure of bowel epithelium to fats and bile acids by formation of insoluble calcium soaps (53-58). Results presented in this study, suggest that dietary calcium intake increases fecapentaene excretion, which may result in reduction of endogenous fecapentaene bioavailability. For instance, bile acid precipitation by calcium is known to reduce facilitated resorption of hydrophobic compounds, as fecapentaenes are.

Positive correlations are found between intake of cereal fiber and excretion of total fecapentaenes as well as of FP(17.7) and FP(18.2). Further, in regression model 2, intake of fiber from vegetables and fruit correlates with total fecapentaenes, and FP(18.2), whereas cereal fiber correlates with FP(17.7). It may be postulated that fiber reduces fecal transit times, and therefore limits possibilities for both fecapentaene synthesis and resorption in time. Additionally, adhesion of fecapentaenes to fibers may result in increased excretion. Therefore, dietary fiber may also act as a protective factor by reducing fecapentaene bioavailability. Further, it should be mentioned that high fiber diets also increase fecal bulk, causing at a constant fecapentaene synthetic rate a diluting effect on fecapentaene concentrations.

In summary, we found that in contrast to the hypothesis, vegetarians excrete significantly more fecapentaenes as compared to omnivores, and that mutagenicity of aqueous fecal extracts can not be attributed to fecapentaenes. Based on these results and the fact that vegetarians are at relatively low risk for colorectal cancer, it could be hypothesized that excretion of fecapentaenes results in diminished exposure and therefore represents reduction of colon cancer risk. Further, it may have become clear that associations between diet and fecapentaene excretion are rather complex. In order to discriminate between effects of dietary factors on fecapentaene synthesis and on fecapentaene excretion and to evaluate the relevance of quantifying fecapentaene excretion as a marker for endogenous exposure, both fecapentaene kinetics in the bowel as well as bacterial fecapentaene production will have to be studied in further detail. Furthermore, the relationship between fecapentaene excretion and in situ intracellular exposure should be established.

\section{References}

1. Wilkins, T.D., Lederman, M., Van Tassell, R.L., Kingston, D.G. and Henion, J. (1980) Characterization of mutagenic bacterial product in human feces. Am. J. Clin. Nutr. 33, 2513-2520.

2. Bruce, W.R., Varghese, A.J., Furrer, R. and Land, P.C. (1977) A mutagen in the feces of normal humans. In: Origins of human cancer, pp 1641-1644. Editors: H.H. Hiatt, J.D. Watson and J.A. Winston. Cold Spring Harbor Laboratory, Cold Spring Harbor, New York. 
3. Bruce, W.R., Baptista, J., Che, T., Furrer, R., Gingerich, J.S., Gupta, I. and Krepinsky, J.J. (1982) General structure of "fecapentaenes" the mutagenic substances in human faeces. Naturwissenschuften, 69, 557-558.

4. Gupta, I., Baptista, J., Bruce, W.R.. Che, C.T., Furrer, R., Gingerich, J.S., Grey, A.A., Marai, L., Yates, P. and Krepinsky, J.J. (1983) Structures of fecapentaenes, the mutagens of bacterial origin isolated from human feces. Biochemistry 22, 241-245.

5. Gupta, I., Suzuki, K., Bruce, W.R., Krepinsky, J.J. and Yates, P. (1984) A model study of fecapentaenes: mutagens of bacterial origin with alkylating properties. Science 225, 521-523.

6. Hirai, N., Kingston, D.G., Van Tassell, R.L. and Wilkins, T.D. (1985) Isolation and structure elucidation of fecapentaenes-12, potent mutagens from human feces. J. Nat. Prod. 4, 622-630.

7. Kingston, D.G., Wilkins, T.D., Van Tassell, R.L., MacFarlane, R.D. and McNeal, J. (1981) Structural studies on a mutagenic bacterial product from human feces. Bunburry Rep. 7, 215-226.

8. Curren, R.D., Putman, D.L., Yang, L.L., Haworth, S.R., Lawlor,T.E., Plummer, S.M. and Harris, C.C. (1987) Genotoxicity of fecapentaene-12 in bacterial and mammalian cell assay systems. Carcinogenesis 8, 349-352.

9. Dypbukt, J.M., Edman, C.C., Sundqvist, K., Kakefuda, T., Plummer, S.M., Harris, C.C., Grafström, R.C. (1989) Reactivity of fecapentaene-12 toward thiols, DNA, and these constituents in human fibroblasts. Cancer Res. 49, 6058-6063.

10. Göggelmann, W., Maier, F.K. and Pfaendler, H.R. (1986) Mutagenicity of synthetic racemic fecapentaene-12. Mutat. Res. 174, 165-167.

11. Peters, J.H., Riccio, E.S., Stewart, K.R. and Reist E.J. (1988) Mutagenic activities of fecapentaene derivatives in the Ames/Salmonella test system. Cancer Lett. 39, 287. 296.

12. Plummer, S.M., Grafstrom, R.C., Yang, L.L., Curren, R.D., Linnainmaa, K. and Harris C.C. (1986) Fecipentaene-12 causes DNA damage and mutations in human cells. Carcinogenesis 7, 1606-1609.

13. Schmid, E., Bauchinger, M., Braselmann, H., Pfaendler, H.R. and Göggelmann, W. (1987) Dose-response relationship for chromosome aberrations induced by fecapentaene-12 in human lymphocytes. Mutat. Res. 191, 5-7.

14. Weston, A., Plummer, S.M., Grafstrom, R.C., Trump, B.F. and Harris C.C. (1986) Genotoxicity of chemical and physical agents in cultured human tissues and cells. Fd. Chem. Toxic. 6/7, 675-679.

15. Vaughan, D.J., Furrer, R., Baptista, J. and Krepinsky, J.J. (1987) The effect of fecapentaenes on nuclear aberrations in murine colonic epithelial cells. Cancer Lett. 37, 199-203.

16. Ward, J.M., Anjo, T., Ohannesian, L., Keefer, L.K., Devor, D.E., Donovan, P.J., Smith, G.T., Henneman, J.R., Streeter, A.J., Konishi, N., Rehm, S., Reist, E.J., Bradford, W.W. and Rice, J.M. (1988) Inacrivity of fecapentaene-12 as a rodent carcinogen or tumor initiator. Cancer Lett. 42, 49-59.

199-203.

17. Weisburger, J.H., Jones, R.C., Wang, C.X., Backlund, J.Y.C., Williams, G.M., Kingston, D.G.I., Van Tassell, R.L., Keyes, R.F., Wilkins, T.D., de Wit, P.P., van der Steeg, M. and van der Gen, A.(1990) Carcinogenicity tests of fecapentaene-12 in mice and rats. Cancer Lett. 49, 89-98.

18. Lederman, M., Van Tassell, R.L., West, S.E., Ehrich, M.F. and Wilkins, T.D. (1980) In vitro production of human fecal mutagen. Mutat. Res. 79, 115-124. 
19. Van Tassell, R.L., MacDonald, D.K. and Wilkins, T.D. (1982) Production of a fecal mutagen by bacteroides spp. Infection and Immuniry, 3, 975-980.

20. Van Tassell, R.L., MacDonald, D.K. and Wilkins, T.D. (1982) Stimulation of mutagen production in human feces by bile and bile acids. Mutat. Res., 103, 233 239.

21. Van Tassell, R.L., Schram, R.M. and Wilkins, T.D. (1986) Microbial biosynthesis of fecapentaenes. In: Genetic toxicology of the diet, pp 199-211. Editor: I. Knudsen. Alan R. Liss, New York.

22. Kingston, D.G.I., Piccariello, D.T., Keyes, R.F., Van Tassell, R.L. and Wilkins, T.D. (1989) Isolation and structure elucidation of plasmalopentaene-12 the biological precursor of fecapentaene-12. Tetrahedron Lett. 30, 6665-6668.

23. Kingston, D.G.I., Van Tassell, R.L. and Wilkins, T.D. (1990) The fecapentaenes, potent mutagens from human feces. Chem. Res. Toxicol. 3, 391-400.

24. Van Tassell, R.L., Piccariello, T., Kingston, D.G., Wilkins, T.D. (1989) The precursors of fecapentaenes: Purification and properties of a novel plasmalogen. Lipids 24, 454-459.

25. De Vet, H.C.W., Sharma, C. and Reddy, B.S. (1981) Effect of dietary fried meat on fecal mutagenic and co-mutagenic activity in humans. Nutr. Rep. Int., 4, 653-660.

26. Dion, P.W., Bright-See, E.B., Smith, C.C. and Bruce, W.R. (1982) The effect of dietary ascorbic acid and tocopherol on fecal mutageniciry. Mutat. Res. 102, 27-37.

27. Hayatsu, H., Arimoto, S. Togawa, K. and Makita, M. (1981) Inhibitory effect of the ether extract of human feces on activities of mutagens: inhibition by oleic and linoleic acids. Mutat. Res. 81, 287-293.

28. Kuhnlein, U., Bergstrom, D.and Kuhnlein, H. (1981) Muragens in feces from vegetarians and non-vegetarians. Mutat. Res. 85, 1-12.

29. Kuhnlein, H.V., Kuhnlein, U. and Bell P.A. (1983) The effect of short-term dietary modification on human fecal mutagenic activity. Mutat. Re's. 113, 1-12.

30. Mower, H.F., Ichinotsubo, D., Wang, L.W., Mandel, M., Stemmermann, G., Nomura, A., Heilbrum, L., Kamiyama, S. and Shimada A. (1982) Fecal mutagens in (wo japanese populations with different colon cancer risks. Cancer Res. 42, 1164-1 169.

31. Reddy, B.S., Sharma, C., Mathews, L. and Engle, A. (1984) Fecal mutagens from subjects consuming a mixed-western diet. Mutat. Res. 135, 11-19.

32. Schiffman, M.H. (1987) Diet and faecal genotoxicity. Cancer Surv. 6, 653-672.

33. Taylor, P.R., Schiffman, M.H., Jones, D.Y., Judd, J., Schatzikn,A., Nair, P.P., Van Tassell, R.L. and Block, G. (1988) Relation of changes in amount and type of dietary fat to fecapentaenes in premenopatisal women. Mutat. Res. 206, 3-9.

34. De Kok, T.M.C.M., Ten Hoor, F. and Kleinjans, J.C.S. (1991) Identification and quantitative distribution of eight analogues of naturally occurring fecapentaenes in human feces by high performance liquid chromatography. Carcinogenesis, 12, 199 205.

35. Doll, R. (1979) Nutrition and cancer: a review. Nutr. Cancer, 1, 35-45.

36. Bausch-Goldbohm, R.P., Van den Brandt, P., Van 't Veer, P., Stumans, F. and Hermus, R.J.J. (1988) Results of the methodological study for the design of a simplified, self-administered questionnaire. In: Diet, hormones and cancer: methodological issues for prospective studies. Editors: Riboli E. and R. Saracci. IARC, Lyon.

37. NEVO Table: Dutch food compositon table. Bureau for Nutritional Education, The Hague 1984. 
38. Van Faassen, A., Van 't Veer, P., Bausch-Goldbohm, R., Sturmans, F. and Hermus, R.J.J. (1991) Self-assessment of faecal pH and bulk in epidemiological studies. Br. $J$. Cancer. in press.

39. Kleinjans, J.C., Pluijmen, M.H., Hageman, G.J. and Verhagen, H. (1989) Stabilization and quantitative analysis of fecapentaenes in human feces, using synthetic fecapentaene-12. Cancer Lett., 44, 33-37.

40. Maron, D.M. and Ames, B.N. (1983) Revised methods for the Salmonella mutagenicity test. Mutat. Res., 113, 173-215.

41 Glatz, J.F.C., Schouten, F.J.M., den Engelsman, G. and Katan, M.B. (1985) Quantitative determination of neutral steroids and bile acids in human feces by capillary gas-liquid chromatography. In: Cholesterol metabolism in health and disease: studies in the Netherlands. pp. 103-112. Editor: Beynen, A.C., Ponsen \& Looijen, Wageningen.

42. Shamsuddin, A.M., Ullah, A., Baten A. and Hale, E. (1990) Stability of fecapentaene12 and its carcinogenicity in F-344 rats. Carcinogenesis, 12, 601-607.

43. Hageman, G., Kikken, R., Ten Hoor, F. and Kleinjans, J. (1988) Assessment of mutagenic activity of repeatedly used deep-frying fats. Mutat. Res., 204, 593-604.

44. Nader, C.J., Potter, J.D. and Weller, R.A. (1981) Diet and DNA-modifying activity in human fecal extracts. Nutr. Rep. Int., 23, 113-117.

45 Reddy, B.S., Sharma,C., Darby, L.,Laakso, K. and Wynder, E.L. (1980) Metabolic epidemiology of large bowel cancer; fecal mutagens in high- and low-risk population for colon cancer. A preliminary report. Mutat. Res., 72, 511-522.

46. Reddy, B.S., Engle, A., Katsifis, S., Simi, B., Bartram, H., Perrino, P. and Mahan, C. (1989) Biochemical epidemiology of colon cancer: Effect of types of dietary fiber on fecal mutagens, acid and neutral sterols in healthy subjects. Cancer Res., 49, 4629 4635.

47. Venitt, S., Bosworth, D. and Alldrick, A.J. (1986) Pilot study of the effect of diet on the mutagenicity of human faeces. Mutagenesis, 1, 353-358.

48. Ehrich, M., Aswell, J.E., Van Tassell, R.L., Walker, A.R.P., Richardson, N.J. and Wilkins, T.D. (1979) Mutagens in the feces of 3 South African populations at different levels of risk for colon cancer. Mutat. Res., 64, 231-240.

49. Reddy, B.S., Sharma, C. and Wynder, E. L., (1980) Fecal factors which might modify the formation of fecal co-mutagens in high-and low-risk population for colon cancer. Cancer Lett., 10, 123-132.

50. Reddy, B.S., Sharma, C., Mathews, L. Engle, A., Laakso, K., Choi, K., Puska, P. and Korpella, R. (1985) Metabolic epidemiology of colon cancer: fecal mutagens in healthy subjects from rural Kuopio and urban Helsinki, Finland. Mutat. Res., 152, 97-105.

5l. Schiffman, M.H., Van Tassell, R.L., Andrews, A.W., Wacholder, S., Daniel, J., Robinson, A., Smith, L., Nair, P.P. and Wilkins T.D. (1989) Fecapentaene concentration and mutagenicity in 718 North American stool samples. Mutat. Res., 222, 351-357.

52 Sorenson, A.W., Slattery, M.L. and Ford, M.H. (1988) Calcium and colon cancer: a review. Nutr. Cancer, 11, 135-145.

53. Bird, R.P., Schneider, R. Stamp, D. and Bruce, W.R. (1986) Effect of dietary calcium and cholic acid on the proliferative indices of murine colonic epithelium. Carcinogenesis, 7, 1657-1661.

54. Garland, C., Shekelle, R.B. and Barrett-Connor, E. (1985) Dietary vitamin D and calcium and risk of colorectal cancer: A 19 year prospective study in men. The 
Lancet, 1, 307-309

55. Lipkin, M., Newmark, H. (1985) Effect of added dietary calcium on colonic epithelial-cell proliferation in subjects at high risk for familial colonic cancer. $N$. Engl. J. Med., 313, 1381-1384.

56. Newmark, H.L., Wargovich, M.J. and Bruce, W.R. (1984) Colon cancer and dietary fat, phosphate, and calcium: a hypothesis. J. Nall. Cancer Inst. 72, 1323-1325.

57. Rozen, P., Fireman, Z., Fine, N., Wax, Y. and Ron, E. (1989) Oral calcium suppresses increased rectal epithelial proliferation of persons at risk of colorectal cancer. Gut 30 , 650-655.

58. Wargowich, M.J., Stephens, L.C. and Gray, K.N. (1989) Effect of two "human" nutrient density levels of calcium on the promotional phase of colon tumorigenesis in the F344 Rat. Proc. Am. Assoc. Cancer Res, 30, 779. 



\title{
Chapter 4
}

\section{Effects of fecal composition on fecapentaene kinetics in the large bowel: A new hypothesis}

T.M.C.M. de Kok, M.L.P.S. van Iersel, F. ten Hoor and J.C.S. Kleinjans.

Based on manuscript submitted to Mutation Research Letters.

\begin{abstract}
Dietary factors have been shown to affect excretion of fecapentaenes, potent mutagens present in human feces. Apart from effects of the diet on the microbial synthesis of fecapentaenes in the bowel, fecapentaene excretion is likely to be indirectly influenced by the composition of the bowel contents, in particular fecapentaene-binding or -solubilizing factors. In the present study, interactions between dietary fiber and fecapentaene-12 (FP-12) have been investigated in vitro, as well as the effects of bile acids and calcium on the solubility of FP-12 in aqueous solutions. The results demonstrated that FP-12 may strongly adsorb to fiber, as indicated by reduced concentrations in the aqueous PBS phase when increasing amounts of fiber are added. This fecapentaene-binding capacity of fiber may explain the positive correlations found between excreted fecapentaene concentrations and fiber consumption. Further, it was found that at concentrations physiologically occurring in feces, both cholic and deoxycholic acid as well as mixtures of bile acids may increase the aqueous solubility of FP-12. This solubilizing effect of bile acids can be reduced by adding calcium at physiological concentrations of $2.5 \mathrm{mg} / \mathrm{ml}$. It is hypothesized that high dietary fiber intake may increase fecapentaene excretion as a result of this fecapentaene-fiber adsorption, which in turn may result in diminished exposure of the human bowel epithelium to these putative initiators of colorectal cancer. In contrast, high concentrations of fecal bile acids may act as fecapentaene-solubilizing factors which increase fecapentaene bioavailability and thereby possibly resulting in increased risk for colorectal cancer.
\end{abstract}




\section{Introduction}

Fecapentaenes form a class of mutagens occurring in the majority of Western populations (1-6). Due to their high mutagenic potential in vitro, fecapentaenes have been suggested to play an essential role in colorectal cancer initiation (7-11). However, in vivo rodent carcinogenicity studies demonstrated predominantly negative results, or effects of fecapentaenes at target sites other than the colon (1116). Epidemiological studies revealed significantly lower fecapentaene levels in feces from colorectal cancer patients as compared to controls (3). Further, fecapentaene excretion was found to be higher in feces from vegetarians, a population at relatively low risk for developing colorectal cancer (Chapter 3) These inverse relations between fecapentaene excretion levels and risk of colorectal neoplasia, suggest that excretion of these compounds as assessed by measurement of fecal concentrations, reduces endogenous exposure rather than marks a risk for the development of colon cancer.

Since diet appears an important risk factor in colorectal cancer, it seems indicated to study relations between dietary factors and fecapentaene excretion. Diet may influence fecapentaene excretion at several levels:

1) Precursors of the fecapentaenes possibly originate from the diet, indicating that dietary habits may determine the maximal level of fecapentaene synthesis.

2) Dietary factors may affect the composition and the metabolic activity of the anaerobic bacterial flora in the bowel, and therefore the fecapentaene synthetic rate.

3) The fecal composition is largely determined by the diet, and may affect the fecal transit-time and thereby fecapentaene synthesis and resorption.

4) Finally, the fecal composition may also modulate bioavailability of fecapentaenes for intestinal resorption by fecapentaene-binding or solubilizing factors.

Measurements of fecal fecapentaene excretion and fecal mutagenicity determined in population studies or dietary trials have shown associations with meat consumption and dietary calcium, whereas inverse correlations with intake of carotene, vitamin $C$ and $E$ have been found (5,17-21). Both positive and negative correlations between intake of dietary fiber and fecal fecapentaene concentrations have been reported $(5,17)$. However, these studies always integrate effects on all four levels as indicated above. As a consequence, effects of dietary factors on fecapentaene concentrations can not be related to one of these specific mechanisms. Therefore, we developed an in vitro model, to study interactions between synthetic FP-12 and factors which may affect digestive tract kinelics by fecapentaene-binding or -solubilizing properties, i.e. various types of fiber, bile acids and calcium.

\section{Experimental and discussion}

The in vitro model we applied consisted of a solid phase of fiber material and a PBS-phase representing the fecal water. After hydration of 50,100 or $200 \mathrm{mg}$ of wheat bran in $1,96 \mathrm{ml}$ PBS $\mathrm{pH}=7.0,45 \mu \mathrm{l}$ of FP- 12 solution was added, yielding a 
concentration of $10 \mu \mathrm{M}$. In order to maintain physiological conditions comparable to the human bowel, no stabilizing agent was added at this stage. The mixture was shaken and incubated at $37^{\circ} \mathrm{C}$ during periods of 30 seconds, 5,15 and 30 minutes. After centrifugation at $0{ }^{\circ} \mathrm{C}, 4500 \mathrm{rpm}$, the supernatant was immediately analysed for FP- 12 content, whereas the pellet was extracted using our previously described method with minor modifications (4). In brief, extraction was performed twice by potter-tube homogenization with $5 \mathrm{ml}$ dichloromethane stabilized with $5 \%$ triethylamine (TEA). Combined extracts were evaporated under nitrogen and redissolved in methanol/TEA (99.5: 0.5). HPLC analysis was performed on a Lichrosorb-RP-18 column (150 x $4.6 \mathrm{~mm}$ ) using acetonitrile / methanol / water / tetrahydrofuran $(36.2: 25.4: 32.6: 6.4)$ as mobile phase and a Spectroflow $783 \mathrm{UV}$ absorbance detector for peak registration at $335 \mathrm{~nm}$ (22). All measurements were performed in duplicate. For determination of the fecapentaene-binding capacity of fiber, distribution ratios were calculated representing the part of totally recovered FP-12 present in the aqueous phase:

$$
\frac{[\mathrm{FP}-12]_{\mathrm{PBS}}}{[\mathrm{FP}-12]_{\mathrm{PBS}}+[\mathrm{FP}-12]_{\text {fiber }}}
$$

This calculation also corrects for inter-assay variation of total FP- 12 recovery.

Figure 1 shows the effect of the amount of wheat bran on the distribution of FP-12 between the aqueous and solid phase. It is clearly demonstrated that the fiberassociated proportion of totally recovered FP-12 increases with the amount of fiber added. The fact that total recovery of nonstabilized FP- 12 is also diminished with increasing amounts of fiber present, from $67 \%$ to $47 \%$ in presence of 50 and 200

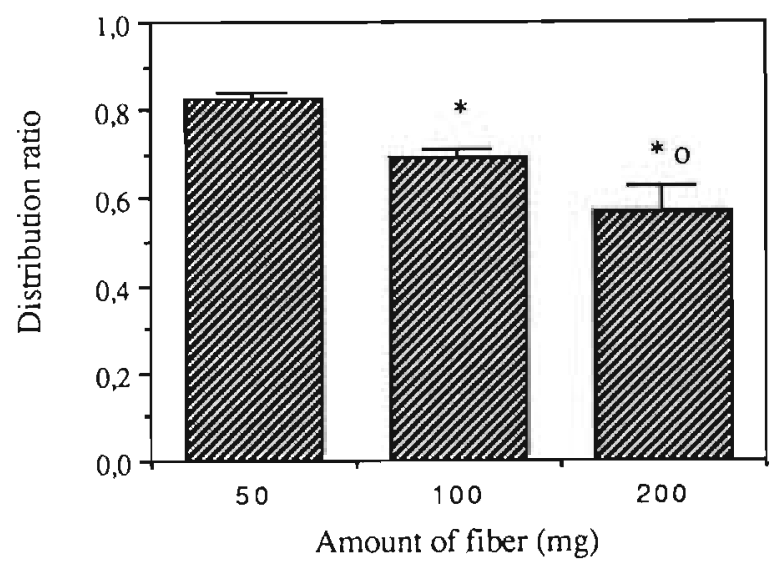

Fig 1: Effect of the amount of wheat bran on the FP-12 distribution ratio (= proportion of totally recovered FP-12 present in the PBS-phase).

* significantly lower as compared to $50 \mathrm{mg}$ wheat bran $(p<0.05)$.

- significantly lower as compared to $100 \mathrm{mg}$ wheat bran $(p<0.05)$. 
$\mathrm{mg}$ wheat bran respectively, suggests that either fiber stimulates the decomposition of FP-12 or more probably that fecapentaene-fiber binding is irreversible to a certain degree. Comparison of recoveries after prolonged incubation periods at 37 ${ }^{\circ} \mathrm{C}$ shows a rapid decay of FP-12 in the PBS phase, up to $50 \%$ within 5 minutes, whereas recovery from the fiber-bound fraction appears nearly constant. This suggests a stabilizing effect of fiber on FP-12 rather than stimulation of its chemical decomposition.

In similar experiments, oat bran demonstrated an identical binding capacity for FP12 as compared to wheat bran. However, hydration of B-cellulose results in a jelly substance which cannot be extracted by potter-tube homogenization. The alternative extraction method by vortexing vigorously for several minutes results in a maximal recovery of less than $5 \%$. This low extraction recovery also suggests a strong adsorption of FP-12 to the B-cellulose. The next experiments have therefore been performed with $200 \mathrm{mg}$ wheat bran and without incubation at $37^{\circ} \mathrm{C}$.

Fecal bile acid excretion is generally linked to increased colon cancer risk (23-27), and several mechanisms of action have been proposed. One of these hypotheses involves the bile-mediated solubilization of hydrophobic mutagens and carcinogens (28). We studied the effect of a mixture of bile acids at physiological concentrations on the distribution of FP- 12 between aqueous and solid phase in the in vitro model
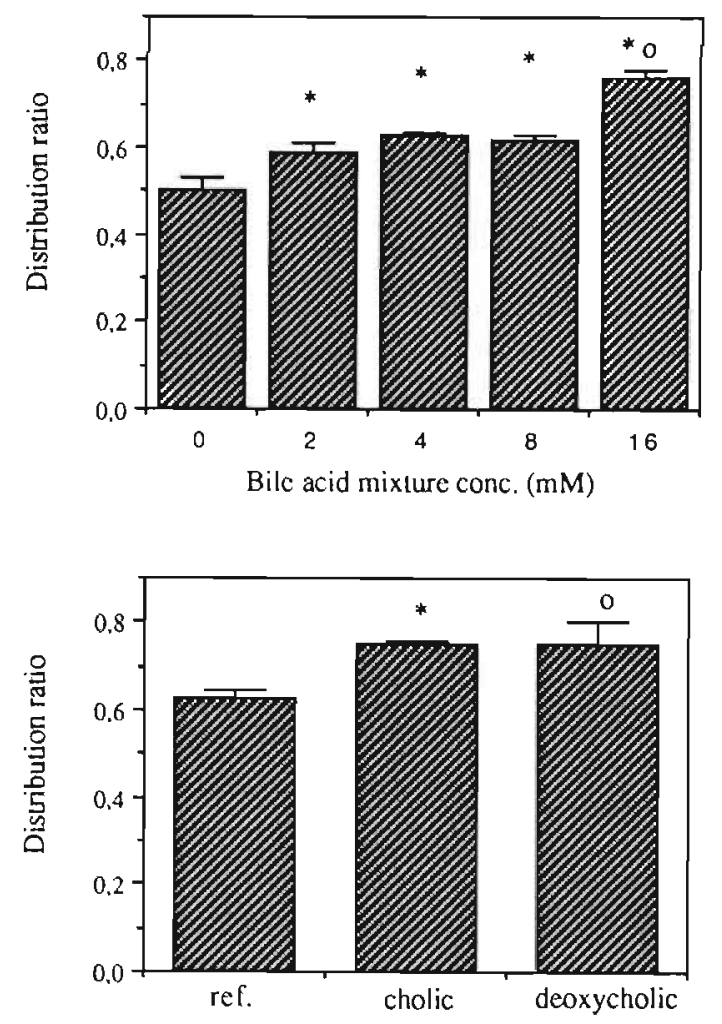

Fig 2: Effect of bile acid mixtures on the FP- 12 distribution ratio in presence of $200 \mathrm{mg}$ of wheat bran.

* significantly higher as compared to $0 \mathrm{mM}$ bile acids ( $\mathrm{p}<$ 0.05 ).

O significantly higher as compared to $8 \mathrm{mM}$ bile acids ( $\mathrm{p}<$ 0.05 ).

Fig 3: Effect of purified cholic and deoxycholic acid on the FP12 distribution ratio.

* Significantly higher as compared to reference without bile acid addition $(p<0.05)$.

$\circ(0.05<\mathrm{p}<0.10)$ 
as described above. A non-specified mixture of bile acids isolated from porcine bile was used (Sigma). Four experiments were conducted, using end-concentrations of $0,2,4,8,16 \mathrm{mM}$ of bile acids. The results indicated that the adsorption of FP- 12 to wheat bran was dose-dependently diminished by the presence of bile acids, as shown by an increased ratio of FP-12 in solution / total of recovered FP-12 (Figure 2). The same effect was found using purified cholic and deoxycholic acid (Sigma) at concentrations of $8 \mathrm{mM}$, although the effect of the latter was not statistically significant (Figure 3 ). It could be excluded that these effects have been produced by variation of $\mathrm{pH}$ by the presence of bile acids, since differences in $\mathrm{pH}$ were relatively small (5.4 - 7.4) and appeared of no influence within this range (data not shown). Further, it appeared that addition of bile acids resulted in an increased total recovery. It can also be excluded that the observed effects of bile acids on the distribution ratio of FP-12 were attributable to stabilizing effects, since the distribution ratio appeared independent of the total amount FP-12 present in the system.

Finally, calcium was added to our in vitro model, since dietary intake of calcium appeared to be most strongly correlating with fecapentaene excretion in our previous study on dietary factors and fecapentaene excretion (Chapter 3). As calcium $\left(\mathrm{CaCl}_{2}\right)$ precipitates with phosphate in $\mathrm{PBS}$ at physiological concentrations of $2.5 \mathrm{mg} / \mathrm{ml}$, these incubations were performed in Tris-buffered saline. The results as shown in Figure 4, indicate that the sole addition of calcium has no effect on the solubilization of FP-12. However, in combination with deoxycholic acid, calcium at $2.5 \mathrm{mg} / \mathrm{ml}$ appeared capable of suppressing the solubilizing effect of this bile acid completely.

- Reference

Calcium

D. DCA

DCA + Calcium
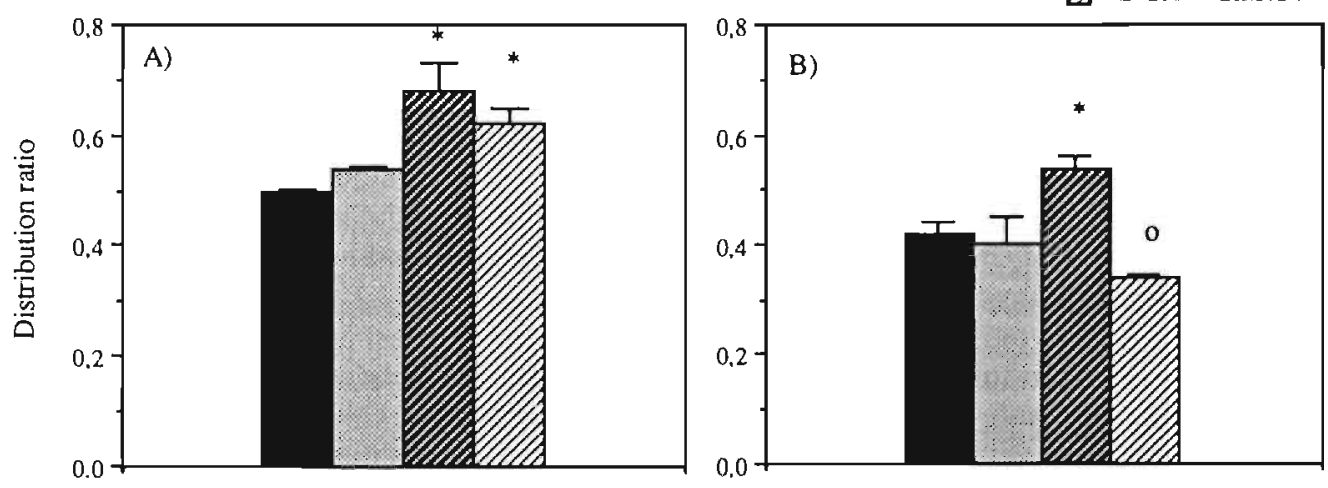

Fig 4: Effect of calcium on the distribution ratio in presence and absence of deoxycholic acid (DCA). A) $\left[\mathrm{Ca}^{2+}\right]=0.9 \mathrm{mg} / \mathrm{ml} ; \mathrm{B}$ ) $\left[\mathrm{Ca}^{2+}\right]=2.5 \mathrm{mg} / \mathrm{ml}$. * significantly higher as compared to reference $(\mathrm{p}<0.05)$.

- significantly lower as compared to distribution ratio with DCA $(p<0.05)$. 
In conclusion, it has been demonstrated that fiber, bile acids and calcium may affect the distribution of fecapentaenes in the digestive tract by fecapentaene-binding or solubilizing properties. As a consequence, these factors may also modify the availability for colonic resorption of fecapentaenes, and therefore intracellular fecapentaene exposure. The finding that fecapentaenes strongly adsorb to fiber material is well in agreement with our earlier report showing elevated fecapentaene excretion levels in vegetarians consuming relatively high amounts of dietary fiber, and a positive correlation between dietary fiber intake and excretion of several fecapentaene analogues (Chapter 3). Earlier studies on fecapentaene excretion or fecal mutagenicity showed inverse correlations with fiber consumption $(17,19,20,29-31)$; this may however be explained by the fact that in these analyses less effective extraction procedures were applied to recover fiber-bound fecapentaene fractions, such as extraction by shaking at room temperature, or using di-ethylether as extraction solvent (4). This implies that studies on excretion of fecal mutagenicity or fecapentaenes will relate only to soluble fecapentaene fractions and probably underestimate total fecapentaene excretion. Further, the hypothesized protective effect of fiber-induced fecapentaene excretion appears to be in agreement with the relatively low fecapentaene excretion levels observed in colorectal cancer patients as compared to controls (3). Furthermore, relatively low fecapentaene levels are also found in feces from individuals on "high risk" omnivorous diets (Chapter 3). This may provide an additional explanation for the generally observed protective effect of dietary fiber in relation to colon carcinogenesis (31-35).

The only attempt made so far to relate fecapentaene and fecal bile acid excretions, failed to show significant associations, except for the concentration of two isomers of FP-12, and fecal concentrations of iso-lithocholic acid (Chapter 3). It should be noted that in this study total bile acid concentrations have been determined, whereas only aqueous bile acids may contribute to the solubilizing effect. On the other hand, consumption of mono-unsaturated fatty acids and fatty foods like butter and margarine, which are known to stimulate bile acid production and excretion, have been negatively related to fecapentaene excretion (17, Chapter 3 ). This supports the hypothesis that solubilization of fecapentaenes by bile acids results in enhancement of fecapentaene resorption and therefore also in reduced total fecapentitene excretion.

Finally, the fact that calcium appeared capable of reducing the solubilizing effect of deoxycholic acid, may explain the positive correlation found between calcium and fecapentaene excretion (Chapter 3).

The results from this investigation demonstrate that complex interactions between fecapentaenes and other fecal components may occur in the bowel lumen. The hypothesis that increased fiber-bound fecapentaene concentrations result in reduced bioavailability, indicates the need to find an alternative for fecapentaene excretion as marker for monitoring exposure of the human bowel to fecapentaenes. For instance, analysis of specific fecapentaene-DNA adducts in colorectal epithelium may provide an useful tool in future research (36). However, such analyses will not be applicable for examination in large populations, and will be limited by the availability of bowel resection specimens. 


\section{References}

1. Schiffman, M.H., Bitterman, P., Viciana, A.L., Schairer, C., Russel, L., Van Tassell, R.L. and Wilkins T.D. (1988): Fecapentaenes and their precursors throughout the bowel- Results of an autopsy study. Mutat. Res. 208, 9-15.

2. Schiffman, M.H., Van Tassell, R.L., Andrews, A.W., Wacholder, S., Daniel, J., Robinson, A., Smith, L., Nair, P.P. and Wilkins T.D. (1989) Fecapentaene concentration and mutagenicity in 718 North American stool samples. Mutat. Res. 222, 351-357.

3. Schiffman, M.H., Van Tassell, R.L., Robinson, A., Smith, L., Daniel, J., Hoover, R.N., Weil, R., Rosenthal, J., Nair, P.P., Schwartz, S., Pettigrew, H., Curale, S., Batist, G., Block, G. and Wilkins, T.D. (1989): Case-Control study of colorectal cancer and fecapentaene excretion. Cancer Res. 49, 1322-1326.

4. De Kok, T.M.C.M., Ten Hoor, F. and Kleinjans, J.C.S. (1991) Identification and quantitative distribution of eight analogues of naturally occurring fecapentaenes in human feces by high performance liquid chromatography. Carcinogenesis 12, 199 . 205.

5. De Kok, T.M.C.M., van Faassen, A., Bausch-Goldbohm, R.A., Ten Hoor, F. and Kleinjans, J.C.S. (1992) Fecapentaene excretion and fecal mutagenicity in relation to nutrient intake and fecal parameters in humans on omnivorous and vegetarian diets. Cancer Lett., 62, 11-21.

6. Block, H.B., Dietrich, M.F., Leake, R., Laidlaw, S.A.,Vinton, N.E. and Kopple, J.D. (1990): Fecapentaene excretion: aspects of excretion in newborn infants, children and adult normal subjects and in adults maintained on total parenteral nutrition. Am.J. Clin. Nutr. 51, 698-704.

7. Curren, R.D., Putman, D.L., Yang, L.L., Hayworth, S.R., Lawlor, T.E., Plummer, S.M. and Harris, C.C. (1987) Genotoxicity of fecapentaene-12 in bacterial and mammalian cell assay systems. Carcinogenesis, 8. 349-352.

8. Peters, J.H., Riccio, E.S., Stewart, K.R. and Reist E.J. (1988) Mutagenic activities of fecapentaene derivatives in the Ames/Salmonella test system. Cancer Lelt. 39, 287. 296.

9. Plummer, S.M., Grafstrom, R.C., Yang L.L., Curren, R.D., Linnainmaa, K. and Harris, C.C. (1986) Fecapentaene- 12 causes DNA damage and mutations in human cells. Carcinogenesis, 7, 1606-1609.

10. Schmid, E., Bauchinger, M., Braselmann, H., Pfaendler, H.R. and Göggelmann, W. (1987): Dose-response relationship for chromosome aberrations induced by fecapentaene- 12 in human lymphocytes. Mutat. Res., 191, 5-7.

11. Shamsuddin, A.M., Ullah, A., Baten, A. and Hale, E. (1991) Stability of fecapentaene12 and its carcinogenicity in F-344 rats. Carcinogenesis, 12, 601-607.

12. Vaughan, D.J., Furrer, R., Baptista, J. and Krepinsky, J.J. (1987) The effect of fecapentaenes on nuclear aberrations in murine colonic epithelial cells. Cancer Letl., 37, 199-203.

13. Hinzman, M.J., Novotney, C., Ullah, A. and Shamsuddin, A.M. (1987) Fecal mutagen fecapentaene-12 damages mammalian colon epithelial DNA. Carcinogenesis, 8 , 1475-1479.

14. Ward, J.M., Anjo, T., Ohannesian, L. Keefer, L.K., Devor, D.E., Donovan, P.J., Smith, G.T., Henneman, J.R., Streeter, A.J., Konishi, N., Rehm, S. Reist, E.J., Bradford, W.W. and Rice, J.M. (1988) Inactivity of fecapentaene-12 as a rodent 
carcinogen or tumor initiator. Cancer Lett. 42, 49-59.

15. Devor, D.E., Henneman, J.R., Keefer, L.K., Logsdon, D.L., Rice, J.M., Streeter, A.J. and Ward, J.M. (1991) Carcinogenicity study of fecapentaene-12 diacetate on skin painting in SENCAR mice. Cancer Lett., 56, 11-15.

16. Weisburger, J.H. Jones, R.C., Wang, C.X., Backlund, J.Y.C., Williams, G.M., Kingston, D.G.I., Van Tassell, R.L., Keyes, R.F., Wilkins, T.D., De Wit, P.P., Van der Steeg, M. and Van der Gen, A. (1990) Carcinogenicity tests of fecapentaene-12 in mice and rats. Cancer Lett. 49, 89-98.

17. Schiffman, M.H. (1987): Diet and faecal genotoxicity. Cancer Surveys 6 653-672.

18. Dion, P.W., Bright-See, E.B., Smith, C.C. and Bruce, W.R. (1982) The effect of dietary ascorbic acid and tocopherol on fecal mutagenicity. Mutat. Res. 102, 27-37.

19. Kuhnlein, U., Bergstrom, D.and Kuhnlein, H. (1981) Mutagens in feces from vegetarians and non-vegetarians. Mutat. Res. 85, 1-12.

20. Kuhnlein, H.V., Kuhnlein, U. and Bell P.A. (1983) The effect of short-term dietary modification on human fecal mutagenic activity. Mutat. Res. 113, 1-12.

21. Jacob, A., Keley, D.S., Pianalto, F.S., Swendseid, M.E., Henning, S.M., Zhang, J.Z., Ames, B.N., Fraga, C.G. and Peters, J.H. (1991) Immunocompetence and oxidant defense during ascorbate depletion of healthy men. Am. J. Clin. Nutr., 54, 1302S$1309 \mathrm{~S}$.

22. Kleinjans, J.C., Pluijmen, M.H., Hageman, G.J. and Verhagen, H. (1989) Stabilization and quantitative analysis of fecapentaenes in human feces, using synthetic fecapentaene-12. Cancer Lett. 44, 33-37.

23. Owen, R.W., Dodo, M., Thompson, M.H. and Hill, M.J. (1987) Fecal steroids and colorectal cancer. Nutrition and Cancer, 9, 73-80.

24. McKeigue, P.M., Adelstein, A.M., Marmot, M.G., Henly, P.J., Owen, R.W., Hill, M.J. and Thompson, M.H. (1989) Diet and fecal steroid profile in a South Asian population with a low colon-cancer rate. Am. J. Clin. Nutr., 50, 151-154.

25. Reddy, B.S., and Wynder, E.L. (1977) Metabolic epidemiology of colon cancer. Fecal bile acids and neutral sterols in colon cancer patients and patients with adenomatous polyps. Cancer, 39, 2533-2539.

26. Reddy, B.S., Martin, C.W. and Wynder, E.L. (1977) Fecal bile acids and cholesterol metabolites of patients with ulcerative colitis, a high-risk group for development of colon cancer. Cancer Res., 37, 1697-1701.

27. Van Faassen, A., Bol, J, van Dokkum, W., Pikaar, N.A., Ockhuizen, T. and Hermus, R.J.J. (1987) Bile acids, neutral steroids, and bacteria in feces as affected by a mixed, a lacto-ovovegetarian, and a vegan diet. Am J. Clin. Nutr., 46, 962-967.

28. Ferguson, L.R., Harris, P.H., Hollands, H.J. and Roberton, A.M. (1990) Effects of bile salts on the adsorption of a hydrophobic mutagen to dietary fiber. Mutat. Res., 245 , $111-117$.

29. Venitt, S., Bosworth, D. and Alldrick, A.J. (1986) Pilot study of the effect of diet on the mutagenicity of human faeces. Mutagenesis 1, 353-358.

30. Reddy, B.S., Sharma,C., Darby, L.,Laakso, K. and Wynder, E.L. (1980) Metabolic epidemiology of large bowel cancer; fecal mutagens in high-and low-risk population for colon cancer. A preliminary report. Mutat. Res. 72, 511-522.

31. Reddy, B.S., Engle, A., Katsifis, S., Simi, B., Bartram, H., Perrino, P. and Mahan, C. (1989) Biochenical epidemiology of colon cancer: Effect of types of dietary fiber on fecal mutagens, acid and neutral sterols in healthy subjects. Cancer Res. 49, 4629. 4635.

32. Burkit, D.P. (1978) Colonic-rectal cancer: fiber and other dietary factors. Am. J. Clin. 
Nutr., 31, S 58-S64.

33. Wilett, W. (1989) The search for the causes of breast and colon cancer. Nature, 338, 389-394.

34. Alberts, D.S., Einspahr, J., Rees-McGee, S., Ramanujam, P., Buller, M.K., Clark, L., Ritenbaugh, C., Atwood, J., Pethigal, P., Earnest, D., Villar, H., Phelps J., Lipkin, M., Wargovich, M. and Meyskens, F.L. (1990) Effects of dietary wheat bran fiber on rectal epithelial cell proliferation in patients with resection for colorectal cancers. $J$. Natl. Cancer Inst., 82, 1280-1285.

35. Freudenheim, J.L., Graham, S., Horvath, P.J., Marshal, J.R., Haughey, B.P. and Wilkinson, G. (1990) Risks associated with source of fiber and fiber components in cancer of the colon and rectum. Cancer Res., 50, 3295-3300.

36. Povey, A.C., Wilson, V.L., Zweier, J.L., Kuppusamy, P., O'Neil, I.K. and Harris C.C. (1992) Detection by 32P-postlabelling of DNA adducts induced by free radicals and usaturated aldehydes formed during the aerobic decomposition of fecapentaene- 12 . Carcinogenesis, 13, 395-401. 



\title{
Chapter 5
}

\section{Case-control study on fecapentaene excretion and adenomatous polyps in colon and rectum}

\author{
T.M.C.M. de Kok, D. Pachen, M.L.P.S. van Iersel, C.G.M.I. Baeten, \\ L.G.J.B. Engels, F. ten Hoor and J.C.S. Kleinjans.
}

Based on manuscript submitted to J. Natl. Cancer Inst.

\begin{abstract}
In search for etiological factors for colorectal cancer, fecal mutagens have gained wide attention. In view of their high mutagenic potential and common occurrence in feces from human populations, fecapentaenes may play an initiating role in colorectal carcinogenesis. To test this hypothesis, fecapentaene excretion levels have been determined in feces from patients with adenomatous polyps and matched controls, positively identified as not suffering from bowel neoplasia. Apart from total fecapentaene levels, also fecal concentrations of various isomers of fecapentaene-12 and fecapentaene- 14 have been quantified separately. Since colorectal carcinoma is known to originate from benign adenomas, measurement of fecapentaene levels in patients diagnosed to have colorectal polyps may indicate exposure levels at the initiating phase of this disease. However, no significant differences in total fecapentaene excretion or fecal concentrations of several fecapentaene analogues were found between cases and controls in this study. Based on these results and observations form a previous case-control study in which colorectal cancer patients have been found to excrete significantly lower levels as compared to controls, it is concluded that fecapentaenes are not likely to contribute to the induction of neoplasia in colonic epithelium. Analysis of nutrient intake during periods of feces collection only showed a few significant correlations between dietary variables and fecapentaene excretion levels. Intake of poly-unsaturated fat and linoleic acid as well as $\mathrm{p} / \mathrm{s}$ ratio appeared to correlate positively with total fecapentaene excretion per day. Further, negative correlations were found between excreted concentrations of total FP-14 and saturated fat, mono-unsaturated fat, total carbohydrates and mono- + di-saccharides. In the male subpopulation, $\mathrm{p} / \mathrm{s}$ ratio showed significant positive correlations with fecapentaene excretion levels. Further, a significant negative correlation was found between total FP-14 concentration and intake of mono-unsaturated fat. In the female subpopulation, a significant inverse correlation was found between total FP-14 concentrations and intake of mono- and di-saccharides. Finally, it was
\end{abstract}


demonstrated by stepwise regression analysis that effects on fecapentaene excretion levels as a consequence of dietary intake and the difference between cases and controls do not interfere.

\section{Introduction}

Reliable colon cancer risk assessment associated with fecapentaene excretion, is hampered by paradoxical results from genotoxicity studies and epidemiological data. Fecapentaenes, a group of unsaturated ether-linked lipids present in human feces, have been shown to be potent mutagens in the Salmonella mutagenicity assay and appear capable of inducing genotoxic effects in various mammalian in vitro test systems. Synthetic fecapentaene-12 (FP-12) has been found to induce sister chromatid exchanges and mutations $(1)$, single strand breaks in DNA $(1,2)$, unscheduled DNA synthesis and cellular transformations (3). In contrast, in vivo studies have predominantly demonstrated the absence of carcinogenic effects (47). So far, only neoplasm induction has been observed in newborn mice at various sites after i.p. injection of FP-12 (8). Based on the strong genotoxic capacity of FP-12 in vitro, and the fact that the majority (> 80\%) of North American and European populations is found to excrete these fecal mutagens in relatively high concentrations [up to several $\mathrm{mg} / \mathrm{kg}$ wet feces (9-14)], it has been suggested that fecapentaenes might be involved in the initiation of colorectal cancer.

Until now, studies on etiological factors in colon carcinogenesis have been mainly based on the indirect measurement of fecal mutagenicity to Salmonella typhimurium strain TA 100 without addition of $S 9$ mix. The results of these studies have indicated that populations consuming "high risk" diets rich in animal fat and with low fiber content appear to excrete more mutagenic feces as compared to "low risk" vegetarian diets (15-21). In contrast, direct measurement of fecapentaene excretion in omnivores and vegetarians demonstrated higher fecal concentrations in the low risk vegetarian population, as is described in Chapter 3. Further, no differences have been found in fecal mutagenicity between controls and patients with either malign or benign colorectal tumors (21-25). On the other hand, in one case-control study using HPLC-UV analysis for quantification of total fecapentaene excretion (11), fecal levels were found to be lower in colorectal adenocarcinoma patients as compared to controls. These inverse relations between HPLC-quantified fecapentaene concentrations and risk of colorectal neoplasia, suggest that excretion of these fecal mutagens indicates protection rather than risk for colorectal cancer initiation.

According to the genetic model of colorectal tumorigenesis as proposed by Vogelstein et al. (see Chapter 1), malignant colorectal tumors arise from preexisting adenomas (26-29). Therefore, fecapentaene excretion patterns are compared in this study between patients with adenomatous polyps in the colon or rectum and matched controls. Fecapentaene excretion levels in feces from these patients may indicate colonic epithelial exposure levels at the early stage of colorectal cancer ontogenesis, and may therefore be related with the initiating phase of this disease. Further, in contrast to the above mentioned case-control study of Schiffman et al. (11), FP-12 and FP-14 as well as their analogues are 
quantified separately. Since diet has been shown to influence fecapentaene excretion as well as fecal mutagenicity (Chapter 3 and 4; 15,30-37), dietary intake is evaluated in both research groups.

\section{Subjects and methods}

\section{Study population}

The research population was recruited during the period from september 1990 until april 1992 from the polyclinics of two hospitals in The Netherlands: the Academic Hospital Maastricht and the Maasland Hospital Sittard. 64 patients subjected to their first sigmoido- or colono-scopy, were asked to collect stool samples prior to the bowel preparation for colonoscopy during a period of 2 days. Patients with a history of bowel surgery or recent use of antibiotics or suppositories were excluded. After examination, 56 individuals were found to have hemorrhoids or other nonneoplastic bowel conditions, and were therefore assigned to the control group. Only 7 cases with adenomatous polyps and 1 case of adenocarcinoma were found. Additionally, 51 cases were recruited from control endoscopy schedules, all having had endoscopic polypectomy at least 6 months previously. Again, patients with previous bowel surgery were not approached, and feces from 1 patient were not analysed because of recent use of antibiotics. One additional case was excluded from analysis because of severe diarrhoea, leaving a total number of 56 cases. Comparison of nutrient intake between the two groups selected before and after endoscopic examination showed no relevant differences, indicating that dietary patterns are generally not changed after diagnosis of colorectal adenoma. Cases were matched to controls on sex and age. Of all cases, $35(=63 \%)$ were found to have one solitary polyp, whereas the remaining 21 cases suffered from 2 or more adenomas simultaneously or over a period of maximal 5 years. Tubular adenomas were found in $46(=82 \%)$, tubulovillous adenomas in $8(=14 \%)$ and villous adenomas in $2(=3 \%)$ of the cases. For statistical analysis, no further subdivision is made based on these pathological aspects because of the relatively small number of cases in subpopulations with other than tubular adenomas. Characteristics of the study population are summarized in Table I. The research protocol was approved of by the medical ethical commission of both the Academic Hospital Maastricht and the Maasland Hospital Sittard.

\section{Stool collection and sample preparation}

Subjects were asked to collect all stool samples at home during two days in coded plastic bags. Participants were clearly instructed to avoid urine contamination, which appeared to be no problem. For each defecation a new plastic bag was used, sealed and stored on dry ice in the dark. When the boxes with dry ice and collected faeces were returned to the laboratory, sample weights were determined. Five subjects indicated on their registration form that a part of the 48 hours stool collection was missing. As a consequence, absolute fecapentaene excretion per 
Table I : Characterization of the study population

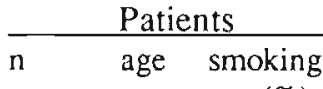

(\%)

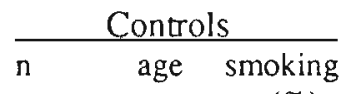

(\%)

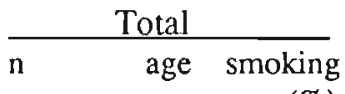

(\%)

$\begin{array}{llllllllll}\text { Men } & 32 & 56.3 \pm 9.8 & 34 & 32 & 50.6 \pm 10.4 & 19 & 64 & 53.4 \pm 10.4 & 26 \\ \text { Women } & 24 & 55.4 \pm 10.2 & 29 & 24 & 51.7 \pm 8.3 & 25 & 48 & 53.6 \pm 9.4 & 27 \\ \text { Total } & 56 & 55.9 \pm 9.9 & 32 & 56 & 51.1 \pm 9.5 & 21 & 112 & 53.5 \pm 9.9 & 26\end{array}$

day could not be calculated for these subjects. After thawing at room temperature, proportional amounts were pooled and homogenized. Of the homogenate, $4-\mathrm{g}$ samples were lyophilized in triply and stored at $-80^{\circ} \mathrm{C}$ until fecapentaene analysis.

\section{Dietary questionnaires}

Dietary questionnaires were developed to register food consumption during 2 days, starting 1 day before feces were collected. Energy and nutrient intake were calculated using the computerized Dutch Nutrient Databank (38). Further, smoking habits and use of medication were inquired. Due to incomplete or incorrect use of the questionnaires, 7 were excluded from analysis, of whom 2 belonged to patients and 5 to individuals from the control group.

\section{Fecapentaene quantification}

Feces from patients and their matched controls was extracted and analysed on the same days, as described previously (12). In brief: 4-g lyophilized material was extracted twice using a potter homogenization apparatus. Dichloromethane (DCM) stabilized with 5\% triethylamine (TEA) was used as extraction solvent. After evaporation of the DCM under nitrogen, extracts were dissolved in diethylether and purified on Silica-60. The fecapentaene-containing eluates were evaporated, and dissolved in methanol/TEA ( $99.5 / 0.5)$. Samples were stored at $80^{\circ} \mathrm{C}$. Analysis was performed by HPLC, using gradient elution and a Spherisorb S5 ODS-2 column ( $250 \times 4.6 \mathrm{~mm}$ i.d.). Mobile phases consisted of acetonitrile / methanol / water / tetrahydrofuran (7.6: $11.8: 75.2: 5.4$ and $56.2: 25.4: 12.0$ : 6.4). Peaks were quantified by a Waters 994 photodiode array detector at $335 \mathrm{~nm}$ monitoring wavelength, and identified by comparison of UV absorbance spectra to stored reference spectra. Fecal fecapentaene levels were calculated by reference to synthetic FP-12 standards and expressed in $\mu \mathrm{g} / \mathrm{kg}$ wet feces, thus presenting an averaged exposure concentration. Additionally, fecapentaene concentrations were expressed in $\mu \mathrm{g} / \mathrm{kg}$ dry weight and total fecapentaene excretion per day was calculated from total fecapentaene concentrations and fecal bulk. 


\section{Statistical evaluation}

Fecapentaene concentrations appeared to be non-normally distributed. Therefore, median values and $10^{\text {th }}$ and $90^{\text {th }}$ percentiles are presented and non-parametric statistical methods were used. Since patients and control subjects were individually matched on sex and age, the Wilcoxon paired sample test was applied for comparison of cases and controls. Student t-test for paired values was used for comparison on nutrient intake between cases and controls. Spearman rank correlation coefficients were determined between consumption of dietary constituents and excreted fecapentaene concentrations. Stepwise multiple regression analysis was performed on logarithmically transformed fecapentaene concentrations and dietary variables. The forward selection procedure selects only significant variables starting with the highest partial correlation. After log transformation, only total fecapentaene concentrations and total fecapentaene excretion appeared to be approximately normally distributed. Therefore, stepwise regression analysis was not performed using fecal concentrations of individual fecapentaene analogues separately. Excreted concentrations of total FP-12 and FP-14 were calculated as the sum of fecal concentrations of $\mathrm{FP}(13.2)+\mathrm{FP}(13.5)+$ $\mathrm{FP}(14.0)$ and $\mathrm{FP}(17.7)+\mathrm{FP}(18.2)$ respectively. In two additional regression models, the factor case/control or the factors sex, case/control and the number of adenomas were forced into the regression model. With the inclusion of each new variable in the model, all variables previously entered were re-evaluated.

\section{Results}

\section{Case-control comparison}

Fecapentaene concentrations as excreted by patients and controls are presented in Figure 1. Since median concentrations of FP(10.9), FP(12.2), FP(13.2) and FP(19.5) appear below the detection level of $5 \mu \mathrm{g} / \mathrm{kg}$ wet feces, these fecapentaenes are not graphically presented. The results show that no significant differences in excreted fecapentaene concentrations are found between both groups. Subdivision into male and female populations demonstrates a trend for lower excretion levels of the male patient group, whereas female patients tend to excrete higher fecapentaene levels. These differences are not statistically significant. Calculation of absolute daily excretion of separate fecapentaene analogues furthermore fails to result in statistical differences (data not shown). Expression of fecapentaene concentrations as $\mu \mathrm{g} / \mathrm{kg}$ dry weight, does not improve statistical reliability either .

In Figure 2, fecapentaene concentrations are given of patients with 2 or more adenomas. These results indicate that these relatively more severe cases tend to excrete higher concentrations of fecapentaenes as compared to their matched controls. However, the differences were not found to be of statistical significance, and appear to result mainly because of diffences between controls rather than cases.

\section{Associations between nutrient intake and fecapentaene excretion}

Daily intake of energy and nutrients of both patients and controls are presented in Table II. The only statistically significant difference is found for the intake of mono- and di-saccharides, indicating that dietary habits of both groups are well 

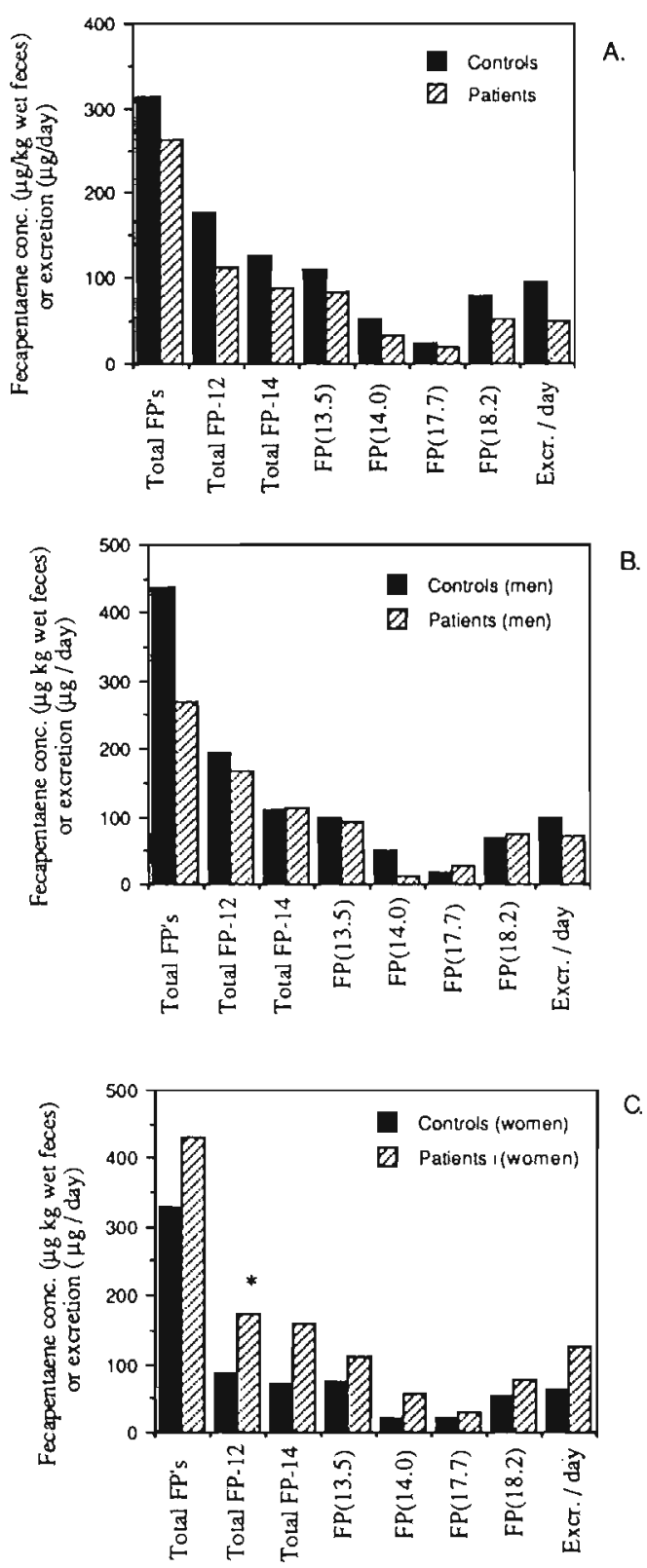

90th percentiles for patients and controls are respectively:

A) total FP: 1887 and 971: Total FP-12: 646 and 1190; total FP-14: 478 and $625 ; \operatorname{FP}(13.5)$ : 742 and 501; FP(14.0): 409 and 160; FP(17.7): 119 and 77; $F P(18.2)$ : 509 and 399; total excretion/day: 370 and 558:

B.

B) total FP: 1582 and 1296; total FP-12: 1110 and 740; total FP-14: 560 and 506; FP(13.5): 740 and 517; FP(14.0): 409 and $200 ; \mathrm{FP}(17.7): 119$ and 122; FP(18.2): 439 and 399 ; total excretion/day: 610 and 413;

C) total FP: 2076 and 971; total FP-12: 1987 and 515 ; total FP-14: 1038 and 492; FP(13.5): 1496 and 407; FP(14.0): 427 and $122 ; \operatorname{FP}(17.7)$ : 130 and 77; FP(18.2): 928 and 373; total excretion/day: 558 and 322.

All 10th percentiles were below the detection limit.

Fig. 1: Comparison of fecapentaene concentrations $(\mu \mathrm{g} / \mathrm{kg}$ wet feces) in feces from patients with adenomatous polyps and matched controls (median values). The right column presents total fecapentaene excretion per day (Excr. / day).

A) total research population, $\mathrm{n}_{1}=\mathrm{n}_{2}=56$; B) men, $\mathrm{n}_{1}=\mathrm{n}_{2}=32$; C) women, $\mathrm{n}_{1}=$ $\mathrm{n}_{2}=24$.

* : marginal statistical reliability $(0.05<\mathrm{p}<0.10)$. 

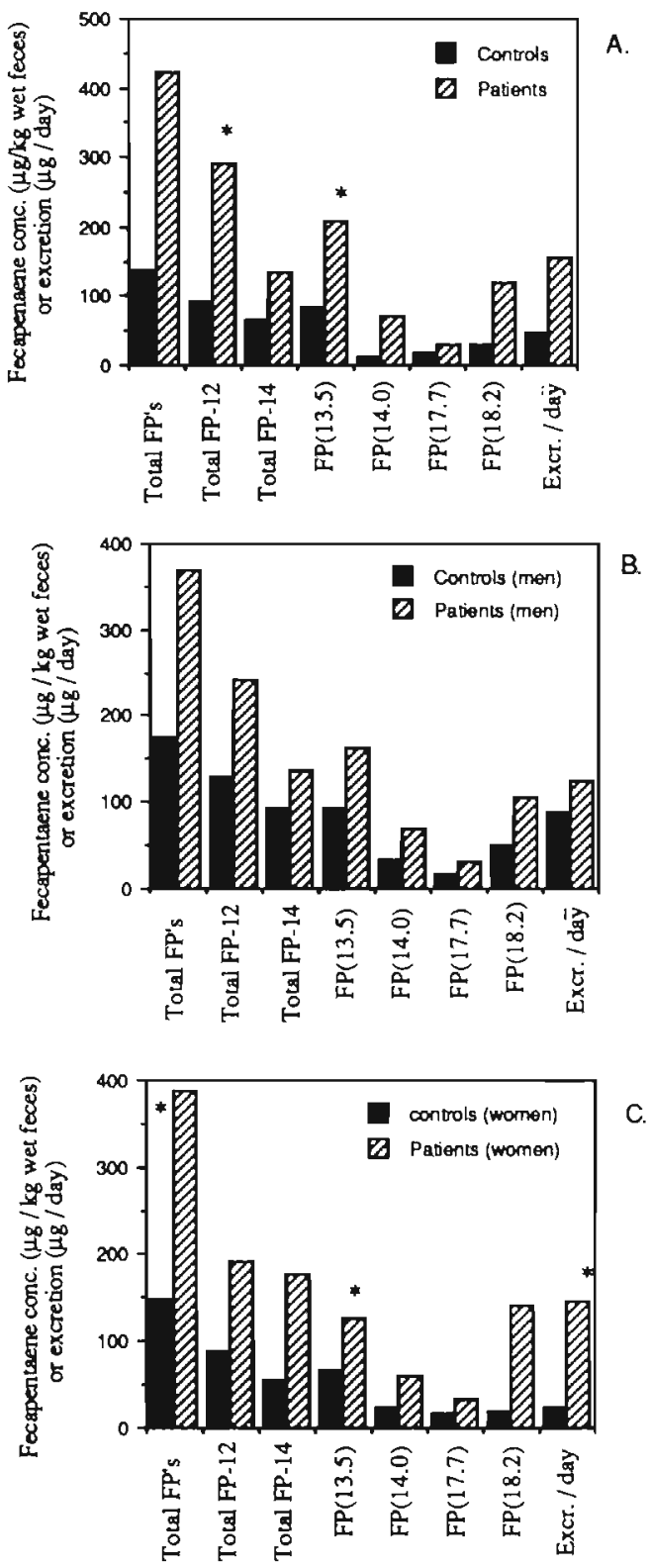

90th percentiles for patients and controls are respectively:

A) total FP: 2014 and 997; Total FP-12: 1493 and 499; total FP-14: 980 and 359; $\operatorname{FP}(13.5)$ : 1061 and $309 ; \mathrm{FP}(14.0): 302$ and 182; $\mathrm{FP}(17.7): 180$ and $64 ; \mathrm{FP}(18.2): 759$ and 276 ; total excretion/day: 714 and 321

B) total FP: 1486 and 1803; total FP-12: 1055 and 1215; total FP-14: 525 and $680 ; \mathrm{FP}(13.5)$ : 750 and $903 ; \mathrm{FP}(14.0)$ : 284 and 301; FP(17.7): 88 and 163; FP(18.2): 436 and 450; total excretion/day: 365 and $653 ;$

C) total FP: 3143 and 701; total FP-12: 2267 and 334 ; total FP-14: 1878 and $314 ; \mathrm{FP}(13.5)$; 1759 and 225; $F P(14.0)$ : 281 and 140; $F P(17.7)$ : 302 and 50; FP(18.2): 1535 and 287 ; total excretion/day: 795 and 101.

All 10th percentiles were below the detection limit.

Fig. 2: Comparison of fecapentaene concentrations ( $\mu \mathrm{g} / \mathrm{kg}$ wet feces) in feces from patients with 2 or more adenomatous polyps and matched controls (median values). The right column presents total fecapentaene excretion per day (Excr. / day). A) total research population, $\mathrm{n}_{1}=\mathrm{n}_{2}=21$; B) men, $\mathrm{n}_{1}=\mathrm{n}_{2}=11$; C) women, $\mathrm{n}_{1}=\mathrm{n}_{2}=10$.

* : marginal statistical reliability $(0.05<p<0.10)$. 
comparable. Comparison of nutrient intake between male cases and controls shows that the average consumption of total carbohydrates and vitamin $\mathrm{C}$ is higher in the control group ( $p<0.05)$, whereas no differences are found between dietary parameters of female cases and controls (data not shown). For the complete study population, daily intake of energy and most nutrients indicated in Table II appears to differ significantly between men and women, with the exception that intake of retinol, vitamin $\mathrm{C}$ and calcium was equal for both groups (data not shown).

Spearman rank correlation coefficients between fecapentaene concentrations and dietary parameters, calculated from data of all subjects as well as for subpopulations consisting of male and female subjects separately, are presented in Table III. In the total research population, intake of poly-unsaturated fat and linoleic acid as well as $\mathrm{p} / \mathrm{s}$ ratio appear to correlate positively with total fecapentaene excretion per day. Further, negative correlations are found between excreted concentrations of total FP-14 and saturated fat, mono-unsaturated fat, total carbohydrates and mono- + di-saccharides. No significant correlations are found between dietary parameters and concentrations of total fecapentaenes or total FP-12 expressed per wet weight. In the male subpopulation, the $\mathrm{p} / \mathrm{s}$ ratio shows the highest correlation coefficient, indicating significant positive relations with concentrations of total fecapentaenes, FP-12 and FP-14 as well as total fecapentaene excretion per day. Further, a significant negative correlation is found

Table II :Daily intake of dietary variables by patients with adenomatous polyps and matched controls.

\begin{tabular}{|c|c|c|c|c|c|c|}
\hline \multirow[t]{2}{*}{ nutrient } & & \multicolumn{2}{|c|}{ Patients $(n=54)$} & \multicolumn{2}{|c|}{ Controls $(n=51)$} & \multirow[t]{2}{*}{$p^{*}$} \\
\hline & & mean & sd & mean & sd & \\
\hline energy & $(\mathrm{KJ})$ & 8730 & 2724 & 9149 & 3073 & ns \\
\hline total fat & (g) & 83.9 & 28.3 & 85.9 & 34.7 & ns \\
\hline saturated fat & (g) & 68.6 & 11.0 & 35.6 & 15.9 & ns \\
\hline mono-unsaturated fat & (g) & 30.6 & 10.8 & 30.8 & 23.2 & $\mathrm{~ns}$ \\
\hline poly-unsaturated fat & (g) & 20.0 & 10.6 & 20.3 & 10.8 & ns \\
\hline linoleic acid & (g) & 16.7 & 9.8 & 17.8 & 10.7 & ns \\
\hline $\mathrm{p} / \mathrm{s}$ ratio & & 0.59 & 0.25 & 0.63 & 0.31 & $\mathrm{~ns}$ \\
\hline total fiber & (g) & 28.3 & 9.3 & 27.5 & 12.1 & ns \\
\hline total protein & (g) & 71.0 & 20.5 & 73.5 & 28.4 & ns \\
\hline animal protein & (g) & 42.9 & 14.4 & 45.0 & 17.6 & ns \\
\hline vegetable protein & (g) & 28.1 & 5.9 & 28.6 & 12.9 & ns \\
\hline total carbohydrates & (g) & 227 & 81.5 & 253 & 90.5 & ns \\
\hline mono- + di-saccharides & (g) & 93.5 & 52.2 & 113 & 44.3 & 0.03 \\
\hline poly-saccharides & (g) & 132 & 46.4 & 134.5 & 57.5 & ns \\
\hline retinol & (mg) & 1.02 & 0.86 & 0.87 & 0.46 & ns \\
\hline vitamin $\mathrm{C}$ & (mg) & 71.9 & 45.2 & 88.9 & 66.9 & ns \\
\hline calcium & $(\mathrm{mg})$ & 783 & 328 & 850 & 498 & ns \\
\hline
\end{tabular}

* Student t-test comparison; ns: not significant. 
Table III:

Associations between dietary parameters and fecapentaene excretion levels.

\begin{tabular}{|c|c|c|c|c|c|c|c|c|c|c|c|c|}
\hline \multirow[b]{2}{*}{ Dietary parameter } & \multicolumn{3}{|c|}{ Total FP / wet weight } & \multicolumn{3}{|c|}{ Total FP / day } & \multicolumn{3}{|c|}{ Total FP-12/wet weight } & \multicolumn{3}{|c|}{ Total FP-14/wet weight } \\
\hline & A & $\mathrm{B}$ & C & A & B & $\mathrm{C}$ & A & B & $\mathrm{C}$ & A & $\mathrm{B}$ & $\mathrm{C}$ \\
\hline energy & - & - & - & - & - & - & - & - & - & -0.17 & - & - \\
\hline total fat & - & - & - & - & - & - & - & - & - & -0.16 & - & - \\
\hline saturated fat & - & - & - & - & - & - & - & - & - & -0.23 & -0.23 & - \\
\hline mono-unsaturated fat & - & -0.20 & - & - & -0.19 & - & - & - & - & -0.19 & -0.28 & - \\
\hline poly-unsaturated fat & - & - & - & 0.22 & 0.24 & - & - & 0.20 & - & - & - & - \\
\hline linoleic acid & - & - & - & 0.21 & 0.21 & - & - & - & - & - & - & - \\
\hline $\mathrm{p} / \mathrm{s}$ ratio & - & 0.28 & - & 0.22 & 0.33 & - & - & 0.25 & - & - & 0.29 & - \\
\hline total fiber & - & - & - & 0.17 & - & - & 0.16 & - & - & - & - & - \\
\hline total protein & - & - & - & - & - & - & - & - & - & - & - & - \\
\hline animal protein & - & - & - & - & - & - & - & - & - & - & - & - \\
\hline vegetable protein & - & - & - & - & - & - & - & . & - & - & - & - \\
\hline total carbohydrates & - & - & - & - & - & - & - & - & - & -0.19 & - & -0.26 \\
\hline mono- + di-saccharides & -0.16 & - & -0.25 & - & - & - & - & - & - & -0.22 & - & -0.35 \\
\hline poly-saccharides & - & - & - & - & - & - & - & - & - & - & - & - \\
\hline retinol & - & - & - & - & - & - & 0.16 & 0.22 & - & - & - & - \\
\hline vitamin $\mathrm{C}$ & - & . & - & - & - & - & 0.16 & 0.21 & - & - & - & - \\
\hline calcium & - & - & - & - & - & - & - & - & - & - & - & 0.25 \\
\hline
\end{tabular}

Spearman rank correlation coefficients between fecapentaene concentrations and daily intake of energy and nutrients $(p<$ $0.05)$. Correlations printed Italic reach only marginal statistical reliability $(0.05<p<0.10)$; - = not significant $(p>0.01)$

A: All subjects included in the analysis $(n=105)$; B: Only male subjects included $(n=60)$; C: Only female subjects included 
Table IV: Stepwise regression analysis on logarithmically transformed fecapentaene concentrations and dietary variables.

\begin{tabular}{|c|c|c|c|c|c|c|c|c|c|c|}
\hline \multirow[b]{2}{*}{ Fecapentaene } & \multirow[b]{2}{*}{ Variable } & \multicolumn{3}{|c|}{$\begin{array}{l}\text { No additional variables } \\
\text { forced in the regression }\end{array}$} & \multicolumn{2}{|c|}{$\begin{array}{l}\text { Case/control comparison } \\
\text { forced in the regression }\end{array}$} & \multicolumn{4}{|c|}{$\begin{array}{c}\text { Case/control; sex; number of } \\
\text { adenomas forced in the regression }\end{array}$} \\
\hline & & B & $\mathrm{SE}$ & $\mathrm{R}^{2}$ & $\mathrm{R}^{2}$ & $F^{1}$ & $\mathrm{R}^{2}$ & $\mathrm{~F} 1$ & $F^{2}$ & $F^{3}$ \\
\hline \multirow[t]{2}{*}{ Total FP } & $\mathrm{p} / \mathrm{s}$ ratio & 0.88 & 0.35 & & & & & & & \\
\hline & mono + di sacch. & $-2.7 \mathrm{e}-3$ & $1.0 \mathrm{e}-3$ & 0.10 & 0.10 & 0.99 & 0.11 & 0.28 & 0.15 & 0.22 \\
\hline \multirow[t]{3}{*}{ Total excretion } & mono unsat fat & 0.012 & 0.004 & & & & & & & \\
\hline & mono + di sacch. & 0.13 & 0.06 & & & & & & & \\
\hline & retinol & $-2.3 e-3$ & $9.0 e^{-4}$ & 0.15 & 0.12 & 0.32 & 0.17 & 0.58 & 0.11 & 0.52 \\
\hline Total FP-12 & - & & & & $7 e-5$ & $8 \mathrm{e}-3$ & 0.01 & 0.01 & 0.02 & 0.94 \\
\hline \multirow[t]{2}{*}{ Total FP-14 } & $\mathrm{p} / \mathrm{s}$ ratio & 0.78 & 0.33 & & & & & & & \\
\hline & mono + di sacch. & $-2.7 e-3$ & $9.5 \mathrm{e}-4$ & 0.11 & 0.11 & 0.26 & 0.11 & 0.23 & 0.09 & 0.02 \\
\hline
\end{tabular}

Regression coefficients (B) and standard error (SE) of variables selected by stepwise regression analyses. Additionally the factor case/control is forced in to the regression model of which $\mathrm{R}^{2}$ and the F-statistic are given. In the third regression model, the variables: case/control, sex and number of adenomas are forced in to the regression. $\mathrm{F}^{1}$ : F-statistic for case/control; $\mathrm{F}^{2}$ : $\mathrm{F}$ statistic for sex; F3: F-statistic for the number of adenomas; all F-values indicate $\mathrm{p}>0.10$. 
between total FP-14 concentration and intake of mono-unsaturated fat. The only significant inverse correlation in the female subpopulation is found between total FP-14 concentrations and intake of mono- and di-saccharides.

Stepwise regression analysis is performed on logarithmically transformed total fecapentaenes, total FP-12 and total FP-14 concentrations as well as total fecapentaene excretion per day, and dietary variables (Table IV). Of all nutrients indicated in Table II, daily intake of total fat, total protein, total carbohydrates and linoleic acid are excluded from this analysis as dietary variables, since they will reveal high partial correlations with other dietary items. Additional variables are the number of adenomas, sex, age, smoking behavior and the comparison of cases and controls. Analysis of the complete population shows that $\mathrm{p} / \mathrm{s}$ ratio, mono- $+\mathrm{di}-$ saccharides, mono-unsaturated fat and retinol are included in regression models relating total fecapentaene levels to nutrient intake. Forcing the factor case/control in the regression model shows no effect on the regression coefficients (not shown) or $\mathrm{R}^{2}$, which indicates that the difference between being case and control does not contribute to the variation in fecapentaene concentrations or excretion. The third regression model yields the same result for forcing sex, and the number of adenomas additionally into the regression equation. The combined dietary factors as indicated in Table IV, are found to explain in total 10, 11 and $15 \%$ of the variation in concentrations of total FP, total FP-14 and total FP excretion/day respectively.

\section{Discussion}

In the multistage model of human colon carcinogenesis as described by Vogelstein et al. $(26,27)$, the occurrence of colorectal adenomas is indicated as an early crucial though benign stadium in the development of colorectal cancer. Therefore, it is indicated to study exposure of the colonic epithelium to potentially initiating agents, such as fecapentaenes, by chemical analysis of feces from patients with adenomatous polyps. Moreover, analysis of fecal concentrations of putative initiators of colorectal carcinogenesis may be of greater relevance at this relatively early phase as compared to later stages near or after diagnosis of carcinoma. Therefore, we compared excretion of fecapentaenes in feces from patients with adenomatous polyps to fecal fecapentaene levels in matched controls. However, no significant differences have been found in concentrations of various fecapentaene analogues as well as total fecapentaene concentrations or excretion per day. Comparison of fecapentaene levels between patients and controls, shows a non-significant trend for higher fecapentaene levels in control subjects. This appears to be in agreement with the results of a previous case-control study on fecapentaene excretion and colorectal cancer (11), which demonstrated significantly lower total fecapentaene concentrations in feces from patients suffering from colorectal carcinoma. It has to be concluded that, in contrast to the study hypothesis, differences in fecapentaene excretion levels between cases and controls are not more pronounced in relatively early stages of colorectal tumorigenesis. Based on these results and the observations from the case-control study previously reported by Schiffman et al. (11), it is suggested that if fecapentaenes play any part in colorectal carcinogenesis, their role is more likely to 
be related to the transformation of adenomas into malignant tumors.

Since diet is known to affect fecapentaene excretion $(13,34)$, dietary intake was registered during the period of feces collection. On average, dietary habits appear not to differ between cases and controls. Associations between nutrient intake and fecapentaene excretion are found to be less pronounced as compared to our previous study on diet and fecapentaene excretion described in Chapter 3. Dietary calcium and fiber, factors previously reported to be most strongly correlating to fecapentaene concentrations, are found to correlate only with marginal statistical reliability to excreted concentrations of FP-14 or FP-12 and total excretion/day, respectively. Furthermore, no significant correlations are found between fecapentaene excretion levels and intake of vitamin $\mathrm{C}$ and $\mathrm{E}$, which has also been reported previously $(34,39)$. This may be a consequence of the fact that in the present study subjects were not selected on extreme dietary habits, as in the study on omnivores and vegetarians. On the other hand, we now report significantly positive correlations between $\mathrm{p} / \mathrm{s}$ ratio and total fecapentaene levels in the male subpopulation, and total fecapentaene concentrations in the complete population. Intake of poly-unsaturated fat and linoleic acid were found to correlate positively with total fecapentaene excretion per day, whereas saturated and monounsaturated fat was found to correlate negatively with total FP-14 concentrations. These correlations are remarkable since results of a human dietary intervention study showed no significant effects of rigorous variation in intake of total amount of fat or $\mathrm{p} / \mathrm{s}$ ratio ( 1.0 versus 0.3 ) over a period of 4 months (40). In contrast, a negative correlation between fecapentaene excretion and intake of monounsaturated fat has been reported in Chapter 3. Based on these results and the fact that significant differences were found in fecapentaene excretion between vegetarians and omnivores (Chapter 3 ), it is concluded that diet is an important determinant of fecapentaene excretion. Although results from various studies appear not always consistent, intake of fiber, calcium, vitamin $\mathrm{C}$ and $\mathrm{E}$ as well as consumption of saturated, mono- and poly- unsaturated fat, and thereby also $\mathrm{p} / \mathrm{s}$ ratio, are indicated as relevant dietary factors in fecapentaene excretion.

In order to establish whether the minor differences in fecapentaene excretion levels between cases and controls despite their non-significance can be explained by differences in dietary habits, stepwise regression analysis has been performed. In agreement with the absence of significant differences between cases and controls as determined by the Wilcoxon paired sample test, the factor case/control was not selected as significant variable in stepwise regression. By forcing the case/control difference in the regression model, no effect was observed on $R^{2}$ or the regression coefficients of significantly relating dietary variables after reevaluation. This indicates that the significant correlations found between dietary parameters and fecapentaene levels are not influenced by differences between cases and controls. The same holds for the parameters sex and number of adenomas which were also found not to contribute significantly to variation in fecapentaene concentrations or excretion.

Apart from dietary determinants of fecapentaene excretion, it has been suggested that also other factors may be of relevance. Studies on the formation of 
plasmalopentaenes in neonatal germ-free pigs have demonstrated that mammalian metabolism may be the origin of these precursors for fecapentaene synthesis (4l43). Unfortunately, dietary intake has not been evaluated in the case-control study by Schiffman et al. (11), which would have enabled discrimination between effects attributable to differences in nutrient intake and variation in fecapentaene levels possibly resulting from differences in the metabolic constitution of cases and controls.

\section{References}

1. Plummer, S.M., Grafstrom, R.C., Yang L.L., Curren, R.D., Linnainmaa, K. and Harris, C.C. (1986) Fecapentaene-12 causes DNA damage and mutations in human cells. Carcinogenesis, 7, 1606-1609.

2. Schmid, E., Bauchinger, M., Braselmann, H., Pfaendler, H.R. and Göggelmann, W. (1987): Dose-response relationship for chromosome aberrations induced by fecapentaene-12 in human lymphocytes. Mutat. Res., 191, 5-7.

3. Curren, R.D., Putman, D.L., Yang, L.L., Hayworth, S.R., Lawlor, T.E., Plummer, S.M. and Harris, C.C. (1987) Genotoxicity of fecapentaene-12 in bacterial and mammalian cell assay systems. Carcinogenesis, 8. 349-352.

4. Ward, J.M., Anjo, T., Ohannesian, L. Keefer, L.K., Devor, D.E., Donovan, P.J., Smith, G.T., Henneman, J.R., Streeter, A.J., Konishi, N., Rehm, S. Reist, E.J., Bradford, W.W. and Rice, J.M. (1988) Inactivity of fecapentaene-12 as a rodent carcinogen or tumor initiator. Cancer Letl. 42, 49-59.

5. Vaughan, D.J., Furrer, R., Baptista, J. and Krepinsky, J.J. (1987) The effect of fecapentaenes on nuclear aberrations in murine colonic epithelial cells. Cancer Lett., 37, 199-203.

6. Devor, D.E., Henneman, J.R., Keefer, L.K., Logsdon, D.L., Rice, J.M., Streeter, A.J. and Ward, J.M. (1991) Carcinogenicity study of fecapentaene-12 diacetate on skin painting in SENCAR mice. Cancer Lett., 56, 11-15.

7. Shamsuddin, A.M., Ullah, A., Baten, A. and Hale, E. (1991) Stability of fecapentaene-12 and its carcinogenicity in F-344 rats. Carcinogenesis, 12, 601-607.

8. Weisburger, J.H. Jones, R.C., Wang, C.X., Backlund, J.Y.C., Williams, G.M., Kingston, D.G.I., Van Tassell, R.L., Keyes, R.F., Wilkins, T.D., De Wit, P.P., Van der Steeg, M. and Van der Gen, A. (1990) Carcinogenicity tests of fecapentaene-12 in mice and rats. Cancer Lett. 49, 89-98.

9. Schiffman, M.H., Bitterman, P., Viciana, A.L., Schairer, C., Russel, L., Van Tassell, R.L. and Wilkins T.D. (1988): Fecapentaenes and their precursors throughout the bowel- Results of an autopsy study. Mutat. Res. 208, 9-15.

10. Schiffman, M.H., Van Tassell, R.L., Andrews, A.W., Wacholder, S., Daniel, J., Robinson, A., Smith, L., Nair, P.P. and Wilkins T.D. (1989) Fecapentaene concentration and mutagenicity in 718 North American stool samples. Mutat. Res. 222, 351-357.

11. Schiffman, M.H., Van Tassell, R.L., Robinson, A., Smith, L., Daniel, J., Hoover, R.N., Weil, R., Rosenthal, J., Nair, P.P., Schwartz, S., Pettigrew, H., Curale, S., Batist, G., Block, G. and Wilkins, T.D. (1989): Case-Control study of colorectal cancer and fecapentaene excretion. Cancer Res. 49, 1322-1326.

12. De Kok, T.M.C.M., Ten Hoor, F. and Kleinjans, J.C.S. (1991) Identification and quantitative distribution of eight analogues of naturally occurring fecapentaenes in 
human feces by high performance liquid chromatography. Carcinogenesis 12, 199205.

13. De Kok, T.M.C.M., van Faassen, A., Bausch-Goldbohm, R.A., Ten Hoor, F. and Kleinjans, J.C.S. (1992) Fecapentaene excretion and fecal mutagenicity in relation to nutrient intake and fecal parameters in humans on omnivorous and vegetarian diets. Cancer Lett., 62, 11-21.

14. Block, H.B., Dietrich, M.F., Leake, R., Laidlaw, S.A.,Vinton, N.E. and Kopple, J.D. (1990): Fecapentaene excretion: aspects of excretion in newborn infants, children and adult normal subjects and in adults maintained on total parenteral nutrition. Am.J. Clin. Nutr. 51, 698-704.

15. Schiffman, M.H. (1986) Epidemiology of fecal mutagenicity. Epidemiologic Rev. 8, 92-105

16. Venitt, S. (1982) Mutagens in human faeces; are they relevant to cancer of the large bowel? Mutat. Res., 98, 265-286.

17. Reddy, B.S., Sharma, C., Darby, L, Laakso, K. and Wynder, E.L. (1980) Metabolic epidemiology of large bowel cancer: fecal mutagens in high- and low-risk populations for colon cancer: a preliminary report. Mutat. Res., 72, 511-522.

18. Reddy, B.S. (1986) Fecal mutagens as a function of diet. In I. Knudsen (ed.) Genetic toxicology of the diet. Alan R. Liss, New York, pp 213-224.

19. Kuhnlein, U., Bergstrom, D. and Kuhnlein, H. (1981) Mutagens in feces from vegetarians and non-vegetarians. Mutat. Res., 85, 1-12.

20. Kuhnlein, H.V., Kuhnlein, U. and Bell, P.A. (1983) The effect of short-term dietary modification on human fecal mutagenic activity. Mutat. Res., 113, 1-12.

21. Furgeson, L.R. and Alley, P.G. (1982) Faecal mutagens from population groups within New Zealand at different risk of colorectal cancer. In: Mutagens in our environment, Alan R. Liss, Inc, New York, 423-429.

22. Correa, P., Paschal, J., Pizzolato, P., Pelon, W. and Lesley, D.E. (1981) Fecal mutagens and colorectal polyps: preliminary report of an autopsy study. In: Bruce, W.R., Correa, P., Lipkin, M. (eds). Banbury Report 7. Gastrointestinal cancer: endogenous factors. Cold Spring Harbor, NY: Cold Spring Harbor Laboratory, pP $119-127$.

23. Bruce, W.R.and Dion P.W. (1980) Studies relating to a fecal mutagen. Am J. Clin. Nutr., 33, 2511-2512.

24. Askew, A.R., Ward, M., Green, M.K. and Reiber, O. (1982): Fecal mutagenesis and colonic cancer. Aust. N.J. Surg. 52, 27-29.

25. Schiffman, M.H., Andrews, A.W., Van Tassell, R.L., Smith, L., Daniel, J., Robinson, A., Hoover, R.N., Rosenthal, J. Weil, R., Nair, P.P., Schwartz, S., Pettigrew, H., Batist, G., Shaw, R. and Wilkins, T.D. (1989): Case-control study of colorectal cancer and fecal mutagenicity. Cancer Res. 49, 3420-3424.

26. Vogelstein, B., Fearon, E.R., Baker, S.J., Nigro, J.M., Kern, S.E., Hamilton, S.R., Bos, J., Leppert, M., Nakamura, Y. and White, R. (1989) Genetic alterations accumulate during colorectal tumorigenesis. In: Cavenee, W., Hastie, N. and Stanbridge, E. (eds) Recessive oncogenes and tumor suppression, Cold Spring Harbor, New York.

27. Vogelstein, B., Fearon, E.R., Hamilton, S.R., Kern, S.E., Preisinger, A.C., Leppert, B.A., Nakamura, Y., White, R., Smits, A.M.M., and Bos, J.L. (1988) Genetic alterations during colorectal-tumor development. New Engl. J. Med., 319, 525-532.

28. Fearon, E.R. and Vogelstein, B. (1990) A genetic model for colorectal tumorigenesis. 
Cell, 61, 759-767.

29. Sugarbaker, P.H., Gunderson, L.L. and Wittes, R.E., (1985) Colorectal cancer. In: DeVita, V.T., Hellman, S . and Rosenberg, S.A. (eds) Cancer, principles and practice of oncology, 1, 2nd edition, J.B. Lippincott company, Philadelphia, pp 795-885.

30. Hayatsu, H., Arimoto, S. Togawa, K. and Makita, M. (1981): Inhibitory effect of the ether extract of human feces on activities of mutagens: inhibition by oleic and linoleic acids. Mutat. Res. 81, 287-293.

31. De Vet,. H.C.W., Sharma, C., and Reddy, B.S. (1981) Effect of dietary fried meat on fecal mutagenic and co-mutagenic activity in humans. Nutrition Reports International, 23, 653-660.

32 Dion, P.W., Bright-See, E.B., Smith, C.C. and Bruce, W.R. (1982) The effect of dietary ascorbic acid and tocopherol on fecal mutagenicity. Mutat. Res. 102, 27-37.

33. Reddy, B.S., Sharma, C., Mathews, L. and Engle, A. (1984): Fecal mutagens from subjects consuming a mixed-western diet. Mutat. Res. 135, 11-19.

34. Schiffman, M.H. (1987): Diet and faecal genotoxicity. Cancer Surveys 6 653-672.

35. Tuyns, A.J., Kaaks, R. and Haelterman, M. (1988) Colorectal cancer and the consumption of foods: A case-control study in Belgium. Nutr. Cancer, 11, 189-204.

36. Kuhnlein, U., Bergstrom, D.and Kuhnlein, H. (1981) Mutagens in feces from vegetarians and non-vegetarians. Mutat. Res. 85, 1-12.

37. Kuhnlein, H.V., Kuhnlein, U. and Bell P.A. (1983) The effect of short-term dietary modification on human fecal mutagenic activity. Mutat. Res. 113, 1-12.

38 NEVO Table: Dutch food composition table. Bureau for Nutritional Education, The Hague 1984.

39. Jacob, A., Keley, D.S., Pianalto, F.S., Swendseid, M.E., Henning, S.M., Zhang, J.Z., Ames, B.N., Fraga, C.G. and Peters, J.H. (1991) Immunocompetence and oxidant defense during ascorbate depletion of healthy men. Am. J. Clin. Nutr., 54, 1302S-1309S.

40 Taylor, P.R., Schiffman, M.H., Jones, D.Y., Judd, J., Schatzkin,A., Nair, P.P., Van Tassell, R.L. and Block, G. (1988): Relation of changes in amount and type of dietary fat to fecapentaenes in premenopausal women. Mutat. Res. 206, 3-9.

41. Van Tassell, R.L., Piccariello, T., Kingston, D.G., Wilkins, T.D. (1989) The precursors of fecapentaenes: Purification and properties of a novel plasmalogen. Lipids 24, 454-459.

42. Kingston, D.G.I., Piccariello, D.T., Keyes, R.F., Van Tassell, R.L. and Wilkins, T.D. (1989) Isolation and structure elucidation of plasmalopentaene- 12 the biological precursor of fecapentaene-12. Tetrahedron Lett. 30, 6665-6668.

43. Kingston, D.G.I., Van Tassell, R.L. and Wilkins, T.D. (1990) The fecapentaenes, potent mutagnes from human feces. Chem. Res. Toxicol., 3, 391-400. 



\title{
Detection of oxygen radicals generated by fecapentaene-12 using electron spin resonance spectroscopy and reduction of fecapentaene mutagenicity to Salmonella typhimurium by hydroxyl radical scavenging
}

\author{
T.M.C.M. de Kok, J.M.S. van Maanen, J. Lankelma, F. ten Hoor \\ and J.C.S. Kleinjans.
}

Based on: Carcinogenesis, 13 (1992) 1249-1255.

\begin{abstract}
Fecapentaenes form a class of potent fecal mutagens and have been suggested to play an initiating role in colon carcinogenesis. Although several indications have been found that fecapentaenes may induce oxidative DNA-damage as well as DNA alkylation, the mechanism of genotoxicity remains unknown. In this study, electron spin resonance spectroscopy with several spin traps has been used in order to determine whether reactive oxygen species can be formed by fecapentaene-12. No specific conditions could be defined resulting in the direct formation of oxygen radicals from fecapentaene-12. However, peroxidation of fecapentaene- 12 by various peroxidative enzymes has been shown to result in the formation of superoxide adducts of the spin traps $\alpha$-(4-pyridyl-1-oxide)- $\mathrm{N}$-t-butylnitrone and 5,5-dimethyl-1-pyrroline $\mathrm{N}$-oxide. Addition of superoxide dismutase resulted in a decreased spectrum intensity, whereas the hydroxyl radical scavenger tert-butyl alcohol appeared of no influence on the signal, both confirming the formation of superoxide. The formation of hydroxyl radical spin adducts has been demonstrated after peroxidation of fecapentaene-12 in incubations with the spin trapping agent 2,2,6,6-tetramethylpiperidine. Further, the effects of scavenging hydroxyl radicals with respect to the genotoxic potential of fecapentaene-12 in the Salmonella mutagenicity assay has been investigated. It was clearly shown that radical scavenging reduced the number of revertants in Salmonella strains TA 100, 102 and 104. This mutagenicity reducing effect was more convincing using both spin traps 5,5-dimethyl-1-pyrroline $\mathrm{N}$-oxide and 2,2,6,6-tetramethylpiperidine as compared to the effect of hydroxyl radical scavengers tert-butyl alcohol and
\end{abstract}


dimethylsulfoxide. Based on these findings, a reaction scheme is proposed suggesting the formation of superoxide after peroxidation of fecapentaene-12, which is subsequently converted to hydroxyl radicals by the iron catalyzed HaberWeiss reaction.

\section{Introduction}

Fecapentaenes have been hypothesized to represent initiating agents in human colon carcinogenesis. These potent genotoxins are found in human feces (1-4) and have been suggested to originate from bacterial modification of polyunsaturated ether phospholipids (5-12). Synthetic fecapentaene-12 (FP-12) appears to be highly mutagenic to several strains of Salmonella typhimurium (13-15) and various genotoxic effects have been observed in murine and mammalian celltypes, comprising sister chromatid exchanges (16), mutations at the hypoxanthineguanosine phosphoribosyl transferase locus (16), unscheduled DNA synthesis (17) and DNA-single strand breaks $(18,19)$. However, the mechanism of fecapentaeneinduced modification of DNA remains unknown. It has been proposed that fecapentaenes can form carbocations that act as alkylating agents (20), and a correlation has been found between mutagenicity and electrophilic reactivity of carbocations derived from a series of model enol ethers. Furthermore, formation of an addition product of FP-12 to a nucleophile has been described (21), as well as reduction of free thiol levels in human fibroblasts after exposure to FP-12, demonstrating the reactivity of FP-12 toward thiols (18). Recent studies have shown that $32 \mathrm{P}$-postlabelling of DNA exposed to FP-12 in vitro results in the formation of adducted nucleotides, detected as additional spots after chromatographic thin thin layer separation and autoradiography $(22,23)$. Another mechanism that has been proposed for fecapentaene genotoxicity, suggests the involvement of reactive oxygen species. High mutagenic activity has been determined in Salmonella typhimurium strains TA 102 and 104, which have both relatively high sensitivity for oxidative mutagens (24). Further, in vitro incubation of calf thymus DNA with FP-12 or FP-14 has been shown to result in dosedependent formation of 2'-deoxy-7,8-dihydro-8-oxoguanosine (8-oxodG) (25). The rapid oxidation of GSH to GSSG during FP-12 exposure of human fibroblasts in vitro also indicates that oxidative reactions may occur (18). The co-formation of reactive oxygen species and FP-12 derived aldehydes has been suggested by the observation of combined spectra of hydroxyl and alkyl spin-trap adducts using electron spin resonance (ESR) measurements (23). This indicates that FP-12 genotoxicity may result from different interactions with DNA, of which the relative importance remains to be determined.

In this study, electron spin resonance spectroscopy is used to detect and identify oxygen species generated by FP-12. Specific conditions that are required for this radical formation are described. Further, the influence of scavenging reactive oxygen species on the expression of fecapentaene mutagenicity to Salmonella is investigated. Based on these results a mechanism for fecapentaene genotoxicity is discussed. 


\section{Materials and methods}

\section{Electron spin resonance spectroscopy}

ESR measurements were performed at room temperature on a Bruker ESP-300 with an ESP 1600 data processor, equipped with an ER 4102 ST standard rectangular cavity. Instrumental conditions are described in the legends to the figures. $\alpha-(4-$ pyridyl-1-oxide)-N-t-butylnitrone (POBN, Sigma) and 5,5-dimethyl-1-pyrroline Noxide (DMPO; Aldrich) were used for trapping both hydroxyl and superoxide radicals, whereas 2,2,6,6-tetramethylpiperidine (TMP; Aldrich) was used to trap hydroxyl radicals as well as singlet oxygen. Solutions of DMPO in nitrogen tlushed milli Q water were purified by gentle mixing with $30 \mathrm{mg} / \mathrm{ml}$ charcoal during 20 minutes at $35^{\circ} \mathrm{C}$. This procedure was repeated three times to remove background ESR signals completely. The oxidized form of TMP (TEMPO) present as an impurity in the commercial product was not removed. All incubations were performed at $37^{\circ} \mathrm{C}$ in a total volume of $0.5 \mathrm{ml} 0.02 \mathrm{M} \mathrm{PBS} \mathrm{pH} 7.0$ containing 0.15 $\mathrm{M} \mathrm{KCl}$. Synthetic FP-12 $(1.17 \mu \mathrm{mol})$ was incubated with $10 \mathrm{mM}$ DMPO or 23 $600 \mathrm{mM}$ TMP, with or without 10 minutes flushing with molecular oxygen. ESR spectra were also recorded after 15 minutes incubation of $0.33 \mu$ mol FP-12 with 4 units of horseradish peroxidase $/ \mathrm{H}_{2} \mathrm{O}_{2}$ (HRP type II, Sigma), 200 units of prostaglandin H synthase/arachidonate (PHS, Sigma) or 200 units of lipoxidase / linoleate (LO, Sigma) and subsequent flushing with oxygen for 10 minutes. Since HRP requires 1-100 $\mathrm{mM} \mathrm{H}_{2} \mathrm{O}_{2}$ as a cofactor, diethylenetriaminepentaacetic acid (DTPA, Janssen) was added as iron chelator, to prevent spontaneous formation of OH-radicals. No DTPA had to be added to incubations with PHS, since $0.2 \mathrm{mM}$ arachidonate was used as cofactor. Also incubations with LO using $0.2 \mathrm{mM}$ linoleate and $1 \mathrm{nM} \mathrm{H} \mathrm{H}_{2} \mathrm{O}_{2}$ as cofactors could be performed without DTPA. In order to investigate the role of superoxide anion radicals in spin adduct formation, 120500 units of superoxide dismutase (SOD, sigma) were added. Incubation mixtures were supplemented with the $\mathrm{OH}$-radical scavenger tert-butyl alcohol (tBA; Aldrich) $(105 \mathrm{mM})$ to determine the involvement of $\mathrm{OH}$-radicals. Incubations in deuteriumoxide were performed to discriminate between ESR signals resulting from reactions of $\mathrm{OH}$ radicals or singlet oxygen with TMP.

Reference spectra were obtained from incubations with $\mathrm{H}_{2} \mathrm{O}_{2}$ for OH-radicals, whereas the hypochlorite- $\mathrm{H}_{2} \mathrm{O}_{2}$ reaction (26) has been used to generate singlet oxygen. A nitrogen-flushed $0.5 \mathrm{mM}$ solution of xanthine, supplemented with 12.5 $\mu l$ adriablastina to increase superoxide production (27), was incubated with 0.05 units of xanthine oxidase (Sigma) in presence of DTPA to form the DMPOsuperoxide adduct.

Effects of oxygen radical scavenging on mutagenicity of FP-12 and of hydroxyl radical generating mutagens

Mutagenicity of synthetic FP-12 in comparison with hydroxyl radical generating mutagens were determined in Salmonella typhimurium tester strains TA 100, 102 and 104. A standard plate incorporation assay was used without preincubation. No metabolic activation system was added. Synthetic FP-12 was provided by Prof. A. van der Gen (28), and stored in methanol/TEA (99.5/0.5) at $-80^{\circ} \mathrm{C}(29)$. Tert-butyl hydroperoxide (TBOOH; Sigma), cumene hydroperoxide ( $\mathrm{COOH}$; $\mathrm{BDH}$ chemicals) and $\mathrm{H}_{2} \mathrm{O}_{2}$ (Perhydrol, Merck) were used as hydroxyl radical forming positive 
controls. Both FP-12 and control mutagens were diluted with methanol/TEA (99.5/0.5) and applied in a volume of $100 \mu \mathrm{l}$. Each concentration was tested in triplicate.

Dimethylsulfoxide (DMSO; Merck), tBA and DMPO, all frequently used as $\mathrm{OH}$ radical scavengers, were included in mutagenicity assays with control mutagens to determine their mutagenicity inhibiting capacity in strain TA 104. DMPO was dissolved in nitrogen-flushed milli $\mathrm{Q}$ water and stored under nitrogen at $-20^{\circ} \mathrm{C}$. In view of the chemical instability of DMPO the interval between the addition of DMPO to the test sample and onset of the mutagenicity test was kept as short as practically possible. Further, the effect of DMSO, tBA, TMP and DMPO on FP-12 mutagenicity was determined. In order to exclude interfering mutagenic or cytotoxic effects, scavengers were tested for direct mutagenicity and cytotoxicity in all three strains. Hydroxyl radical scavengers were administered in non-cytotoxic concentrations varying from 20 to $1400 \mu \mathrm{mol} / \mathrm{plate}$. FP- 12 concentrations of 0.5 $\mu \mathrm{g} /$ plate were used in tester strains TA 100 and 104, whereas a higher concentration of $2.5 \mu \mathrm{g} /$ plate was necessary to induce a significant mutagenic effect in TA 102 . All test samples contained $50 \mu \mathrm{l}$ methanol/TEA (99.5/0.5) with varying concentrations of FP-12 and $100 \mu \mathrm{I}$ DMSO, tBA, TMP or DMPO solutions in milli Q water. Further, in Salmonella strain TA 100 the effect of DMSO, tBA and DMPO on cytotoxicity of FP-12 at toxic concentration of $2.0 \mu \mathrm{g} /$ plate was determined. Toxicity assays were performed on histidine-enriched agar plates with $10^{6}$ diluted bacterial suspension in combination with various doses of FP-12 and scavengers. The method of least significant differences (LSD) was used to evaluate mutagenicity data (30). LSD values at confidence levels of $P<0.01$ and $P<0.001$ were determined at respectively 110 and 117 for strain TA 100,265 and 293 for TA 102 and at 399 and 417 for TA 104.

\section{Results}

\section{Electron spin resonance spectroscopy}

Incubation of synthetic FP-12 with DMPO, POBN or TMP does not result in detection of spintrap-adducts. Prolonged incubation time or vigorous flushing of the incubation mixture with molecular oxygen appear to be of no influence on radical formation. Apparently, no radicals are generated by FP-12 spontaneously.

ESR spectra of incubations of FP-12 with HRP, PHS and LO are given in Figure 1, and compared with the DMPO-OOH signal obtained by generating superoxide by the xanthine / xanthine oxidase system in presence of adriablastina. Although the hyperfine structure is not very pronounced, DMPO-adducts formed after peroxidation of FP-12 resemble the DMPO-OOH spectrum $\left(A_{N}=14.3 \mathrm{G}\right)$. Remarkably, DMPO-OOH spectra in these FP-12 incubations are recorded after 15 minutes incubation at $37^{\circ} \mathrm{C}$ and 10 minutes flushing with oxygen, whereas the DMPO-OOH signal formed by the $x$ anthine/xanthine oxidase system disintegrates completely to form DMPO-OH within 6 minutes. When 120 units of SOD are added to incubations with HRP and PHS, the ESR signal is decreased in intensity by respectively 64 and $31 \%$. Since integration of ESR signals with low intensity appears not to be accurate, this reduction in intensity is calculated from signal-tonoise ratios. No effect of $t B A$ is found on the intensity of the DMPO-OOH signal. 


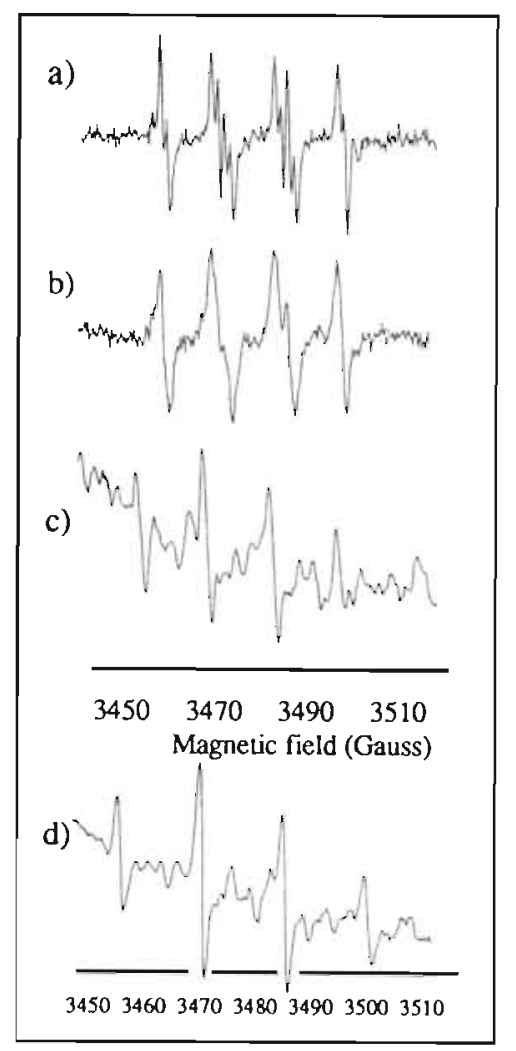

Fig. 1: ESR signals of incubations in presence of $10 \mathrm{mM}$ DMPO of a) xanthine/xanthine oxidase/ adriablastina; 1 scan within 3 minutes, $A_{N}=14.3 G$, $\mathrm{A}_{\mathrm{H}}{ }^{\mathrm{B}}=3.5 \mathrm{G}, \mathrm{A}_{\mathrm{H}} \gamma=0.7 \mathrm{G}$; b) FP-12/ $\mathrm{HRP} / \mathrm{H}_{2} \mathrm{O}_{2}$ / DTPA / $\mathrm{KCl}, 60$ scans after 15 minutes at $37^{\circ} \mathrm{C} / 10$ minutes flushing oxygen, $A_{N}=14.3 \mathrm{G}$; c) FP-12 / LO / linoleic acid $/ \mathrm{H}_{2} \mathrm{O}_{2}$ (1 $\left.\mathrm{nM}\right), 50$ scans after 5 minutes at $37^{\circ} \mathrm{C} / 5$ minutes flushing oxygen, $\mathrm{A}_{\mathrm{N}}=14.3 \mathrm{G}$; d) FP-12/ PHS / arachidonic acid / haematine (1 $\mu \mathrm{M}), 50$ scans after 15 minutes at $37^{\circ} \mathrm{C} /$ 10 minutes flushing oxygen, $A_{N}=14.6$ G. Instrumental conditions are as follows: modulation amplitude, $1 \mathrm{G}$; receiver gain $2 \cdot 10^{5} \mathrm{msec}$; time constant, $40.96 \mathrm{msec}$; scan time, $20.97 \mathrm{sec}$; power, $100 \mathrm{~mW}$; magnetic field, $3480 \pm 40 \mathrm{G}$.

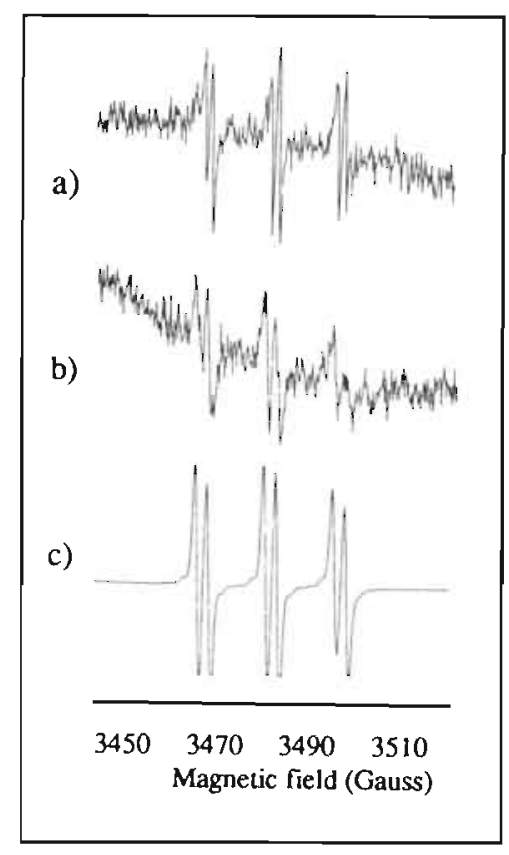

Fig. 2: ESR signals of incubations of a) xanthine / xanthine-oxidase / adriablastina / DTPA / $10 \mathrm{mM}$ POBN, 5 scans after 5 minutes incubation, $A_{N}=15.2 \mathrm{G}$, $A_{H^{B}}{ }^{B}=2.2 \mathrm{G}$; b) $x$ anthine/xanthine oxidase/DTPA/ $50 \mathrm{mM}$ POBN without adriablastina, 5 scans after 5 minutes incubation, $A_{N}=15.4 \mathrm{G}, A_{H}{ }^{B}=2.8 \mathrm{G} ; \mathrm{c}$ ) FP-12/HRP/H $\mathrm{H}_{2} / \mathrm{DTPA} / 50 \mathrm{mM}$ POBN, 7 scans after 15 minutes at $37^{\circ} \mathrm{C} / 10$ minutes flushing oxygen, $A_{N}=15.4 G, A_{H} B=2.8$ $\mathrm{G}$. Instrumental conditions are as indicated in the legends of Figure 1. 
ESR spectra of incubations with xanthine / xanthine-oxidase with and without adria-blastina and of FP-12/HRP using POBN as radical trapping agent, are shown in Figure 2. Splitting constants are slightly influenced by the addition of adriablastina.

Without adriablastina, ESR spectra of xanthine/xanthine oxidase and FP-12/HRP appear identical $\left(A_{N}=15.4 \mathrm{G}, A_{H}{ }^{B}=2.8 \mathrm{G}\right)$. Comparison of the spectra with the POBN-OH spectrum obtained after incubation of POBN with $\mathrm{H}_{2} \mathrm{O}_{2}\left(\mathrm{~A}_{\mathrm{N}}=14.8 \mathrm{G}\right.$, $\mathrm{A}_{\mathrm{H}} \mathrm{B}=1.8 \mathrm{G}$ ) indicates that both spectra can be well distinguished. The signal intensity after incubation of FP-12 with HRP is remarkably high. This intensity is reduced by $31 \%$ upon addition of 120 units of SOD.

When FP-12 is incubated with $\mathrm{HRP} / \mathrm{H}_{2} \mathrm{O}_{2}$ in presence of $23 \mathrm{mM}$ TMP, a greatly increased signal is recorded as compared to the background TEMPO signal. However, this signal appears also to be present in reference incubations of $\mathrm{HRP} / \mathrm{H}_{2} \mathrm{O}_{2}$ without $\mathrm{FP}-12$. The intensity of this signal is not influenced by adding

tBA, but is enlarged when the incubation is performed in deuteriumoxide (data not shown). Apparently, HRP in combination with $\mathrm{H}_{2} \mathrm{O}_{2}$ produces singlet oxygen itself, and therefore this enzymatic system seems rather inappropriate for investigating the production of singlet oxygen by FP-12. The generation of singlet oxygen by purified peroxidase-systems, including HRP, chloroperoxidase, lactoperoxidase and myeloperoxidase, has previously been demonstrated by chemoluminescence (31-34).

Fig. 3: ESR signals of incubations of: a) $100 \mathrm{mM} \mathrm{H} \mathrm{O}_{2}$ and $23 \mathrm{mM} \mathrm{TMP}$;

b) 200 units PHS, $0.2 \mathrm{mM}$ arachidonate, haematine and $23 \mathrm{mM}$ TMP; c) as incubation b with $0.33 \mathrm{mM} \mathrm{FP}-12$, d) as incubation b with $0.33 \mathrm{mM} \mathrm{FP}-12$ and $105 \mathrm{mM} \mathrm{tBA}, \mathrm{e})$ as incubation $\mathrm{b}$ with $0.33 \mathrm{mM} \mathrm{FP}-12$ and 120 units of SOD. Instrumental conditions are as indicated in the legends of Figure 1, number of scans is 50 . 
In Figure 3, ESR spectra of incubation of PHS with FP-12 are compared to the TEMPO-signal obtained after incubation of TMP with $\mathrm{H}_{2} \mathrm{O}_{2}$. Incubation of 0.33 $\mathrm{mM} \mathrm{FP}-12$ results in a threefold increase of the ESR-signal as compared to the control incubation without fecapentaenes (Figure 3b, c). Further, the TEMPO signal $\left(A_{N}=17.2 \mathrm{G}\right)$ in FP-12 incubations is reduced to the background intensity by addition of tBA (Figure 3d), whereas it increases when FP-12 is incubated with PHS and SOD simultaneously (Figure 3e).

Effects of oxygen radical scavenging on mutagenicity of FP-12 and hydroxyl radical generating mutagens

Synthetic FP-12 appears to be mutagenic in Salmonella strains TA 100, 102 and 104, as is shown in Figure 4. All hydroxyl radical generating mutagens induce significant numbers of revertants in these strains, indicating that these three strains are susceptible to mutagenic effects induced by hydroxyl radicals. Effects of DMSO, tBA, TMP and DMPO on the mutagenicity to strain TA 104 of hydroxyl radicals originating from $\mathrm{TBOOH}$ or $\mathrm{COOH}$ are illustrated in Figure 5. Since all hydroxyl radical scavengers significantly reduce the number of revertants (except for DMSO in combination with TBOOH), this assay appears suitable to demonstrate hydroxyl radical mediated mutagenicity.
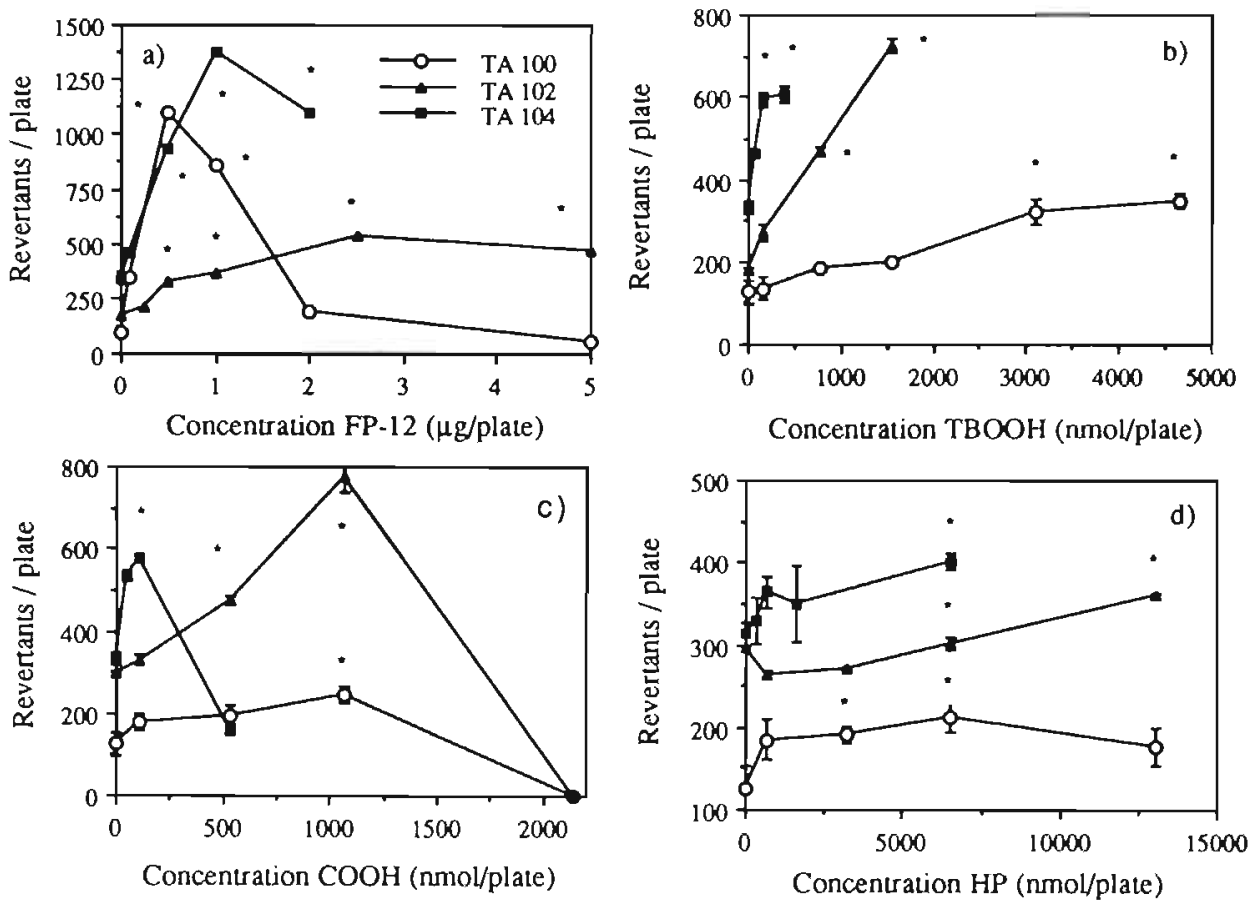

Fig. 4: Mutagenicity to Salmonella typhimurium TA 100, TA 102 and TA 104 of a): synthetic FP-12; b): t-butyl hydroperoxide; c): cumene hydroperoxide; d): hydrogenperoxide. ${ }^{*}$ indicates significant mutagenicity (LSD, p $<0.01$ ). 

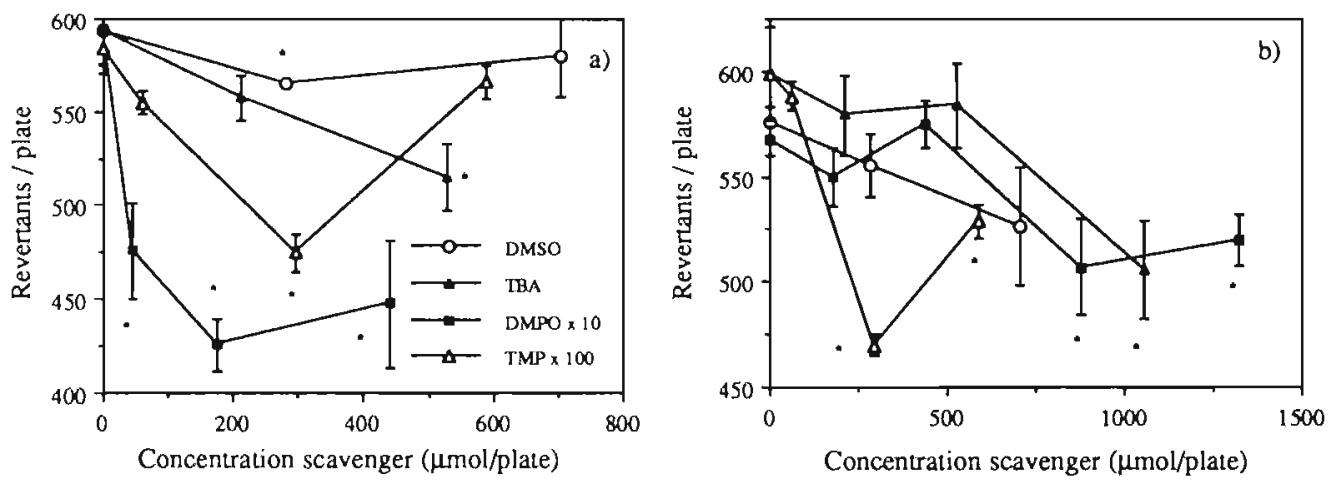

Fig. 5: Reduction of the mutagenic effect to Salmonella typhimurium TA 104 of a): t-butyl hydroperoxide (155 nmol/plate); b): cumene hydroperoxide (107 nmol/plate), by addition of DMSO, TBA or DMPO. The concentration of DMPO is a factor 10 lower as compared to concentrations of DMSO and TBA. * indicates a significant reduction of revertants ( Student-t test, $p<0.05$ ).

Interference of radical scavenging with the mutagenicity of FP-12 is shown in Figure 6. Generally, all scavengers are shown to be capable of reducing FP-12 mutagenicity. DMPO and TMP, administered in concentrations of a factor 10 respectively 100 lower as compared to DMSO an $\mathrm{BBA}$, appear to reduce FP-12 mutagenicity most efficiently. An exception is found for TMP producing no significant reduction of revertants in strain TA 104. Further, mutagenicity reducing effects of tBA are determined in strains TA 102 and TA 104, whereas a significant increase of the number of revertants is found in TA 100 . DMSO is shown to reduce FP-12 mutagenicity only in strain TA 102 at a concentration of $1.4 \mathrm{mmol} / \mathrm{plate}$.

The cytotoxic effect to TA 100 of $2 \mu \mathrm{g} \mathrm{FP-12/plate} \mathrm{is} \mathrm{shown} \mathrm{to} \mathrm{be} \mathrm{reduced} \mathrm{by}$ addition of hydroxyl radical scavengers (data not shown). DMPO appears to increase the number of colonies most efficiently, reaching a maximal effect at a concentration of $20 \mathrm{mmol} /$ plate. Addition of DMSO and $\mathrm{tBA}$ results in maximal reduction of cytotoxicity at concentrations of 1100 and $1400 \mathrm{mmol} / \mathrm{plate}$ respectively. At the applied concentrations no mutagenic or cytotoxic effects have been shown to be induced by $\mathrm{OH}$-radical scavengers to any strain. However, TMP concen-trations exceeding $15 \mu \mathrm{mol} /$ plate appear to be cytotoxic to strains TA 100 and 102, and no surviving colonies of TA 104 are found on plates containing 10 $\mu \mathrm{mol}$ TMP.

It is concluded that both FP-12 mutagenicity and cytotoxicity can be reduced by $\mathrm{OH}$-radical scavenging, and therefore $\mathrm{OH}$-radicals can be generated in the Salmonella mutagenicity assay in presence of FP-12. 

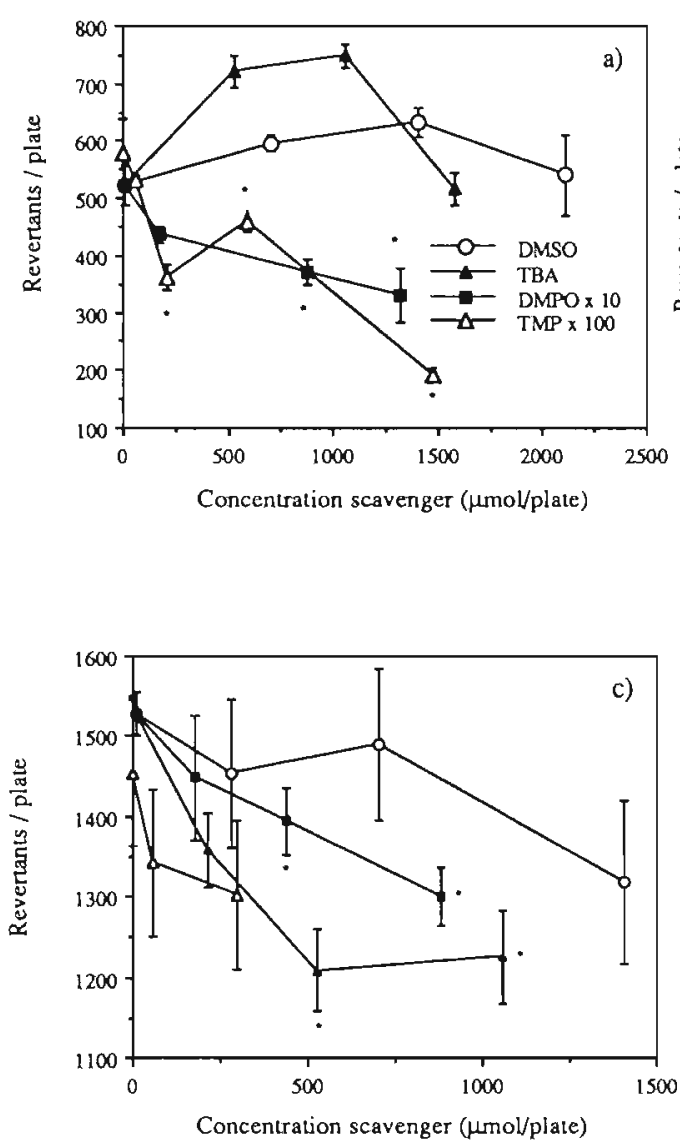

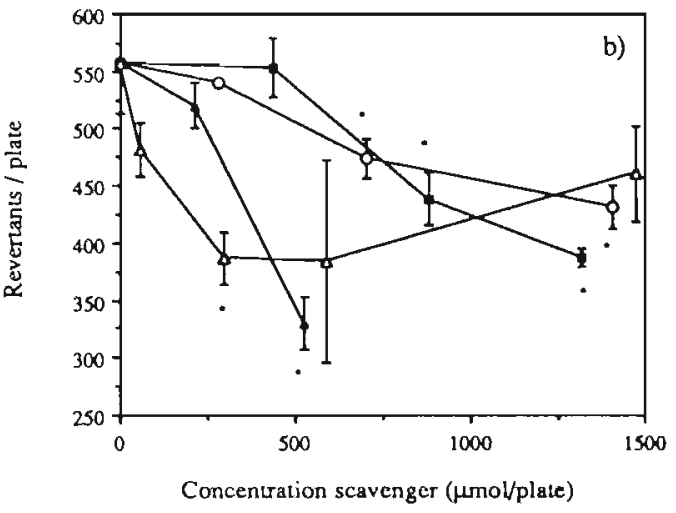

Fig. 6: Effects of DMSO, TBA, DMPO and TMP on the mutagenicity of FP-12 to Salmonella typhimurium strain: a) TA 100, [FP12] $=0.5 \mu \mathrm{g} / \mathrm{plate}$; b) TA 102, [FP-12] $=2.5 \mu \mathrm{g} /$ plate; c) TA 104, [FP-12] $=$ $0.5 \mu \mathrm{g} /$ plate. The concentration of DMPO and TMP are a factor 10 resp. 100 lower as compared to concentrations of DMSO and TBA.

* indicates a significant reduction of revertants ( Student-t test, $\mathrm{p}<0.05$ ).

\section{Discussion}

Since fecapentaenes are mutagenic to Salmonella strains that are highly susceptible to oxidative damage (24) and hydroxylation of the C-8 position of guanine residues in DNA by FP-12 and FP- 14 has been reported (24), it is indicated to search for reactive oxygen species produced by fecapentaenes. The formation of 8-oxodG has been shown to occur directly after in vitro incubation of calf thymus DNA with synthetic fecapentaenes (25). However, in the present study no oxygen radicals are found to be generated by FP-12 spontaneously, despite the fact that experimental conditions of both DNA incubations and ESR measurements are quite comparable; DNA incubations are performed in Tris- $\mathrm{HCl}(\mathrm{pH}=7.4)$, containing $0-3$ mM FP- 12 , at $37^{\circ} \mathrm{C}$ for $1-3$ hours, whereas ESR spectra are recorded in $0.02 \mathrm{mM}$ PBS ( $\mathrm{pH}=7.0$ ), containing $0.66-2.35 \mathrm{mM} \mathrm{FP}-12$, after 15 minutes at $37{ }^{\circ} \mathrm{C}$ and up to 1 hour scanning. Further, our negative results on spontaneous radical formation appear to be conflicting with ESR measurements reported by Povey et al. (23). These investigators report combined oxy/alkyl spectra after incubation of DMPO and PBN with FP-12. It should be noted however, that these incubations have been 
conducted in presence of $18 \%$ ethanol, which is known to react with $\mathrm{OH}$-radicals to form $\alpha$-hydroxyethyl radicals (35). This secondary radical may form a different DMPO-adduct $\left(A_{N}=15.8 ; A_{H}{ }^{B}=22.8\right)$. Although no splitting constants have been reported in the study by Povey et al., the strong spectral resemblance indicates that the suggested composite oxy/alkyl spectrum is more likely originate form the DMPO trapped $\alpha$-hydroxyethyl radical. Nevertheless, Povey's results indicate that oxygen radicals are generated during FP- 12 decomposition.

In our analyses, enzymatic peroxidation of FP-12 by HRP, PHS or LO appeared to be essential for the detection of DMPO-OOH, indicating that superoxide is generated under these conditions. The fact that SOD reduces the DMPO-OOH signals after incubation of FP-12 with HRP and PHS, confirms the peroxidative formation of superoxide from FP-12. Since tBA has no effect on the signal intensity, involvement of OH-radicals in the DMPO-adduct formation is unlikely. However, the middle two lines in spectra of FP-12 incubations with LO and PHS (Figure 1c, d) appear slightly more intense, and it therefore may be argued that also DMPO-OH is present. The superoxide adduct of DMPO is still present after 15 minutes incubation whereas the positive control formed by the xanthine/xanthine oxidase system rapidly decays; this is probably caused by continuous production of superoxide from FP-12. Further, it has been described that high concentrations of superoxide destroy DMPO-OH (36) which explains why disintegration of DMPO$\mathrm{OOH}$ to DMPO-OH does not occur in incubations with HRP and only slightly in presence of PHS and LO. On the other hand, it has been reported that increased formation of superoxide destabilizes the DMPO-OOH adduct (37), which maybe explains the less pronounced hyperfine structure.

In contrast to DMPO-OOH, the superoxide adduct of POBN has been shown not to decompose into POBN-OH (35). Therefore, this spin trap is used to confirm the generation of superoxide by HRP from FP-12. Addition of adriablastina to the xanthine/xanthine oxidase system increases superoxide production but also appears to slightly modulate splitting constants. Therefore, rather high concentrations of POBN ( $50 \mathrm{mM}$ ) have been used to generate the superoxide-adduct by

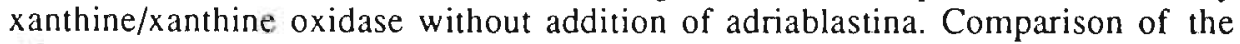
POBN-adduct generated by FP- 12 with this superoxide-adduct clearly indicates that both ESR signals are identical, and confirm that superoxide is formed after incubation of FP-12 with peroxidative enzymes. Further evidence for the production of superoxide is provided by the fact that addition of SOD reduces POBN-OOH production in incubations with HRP.

Incubation of TMP with $\mathrm{H}_{2} \mathrm{O}_{2}$ has clearly demonstrated that TEMPO is not only formed by reaction with singlet oxygen (26) but also by trapping $\mathrm{OH}$-radicals. Therefore, the increased signal observed after incubation of TMP with FP-12 and PHS can be attributed to the generation of either or both OH-radicals or singlet oxygen. Signal reduction to the background level by addition of tBA clearly demonstrates the involvement of $\mathrm{OH}$-radicals. Addition of SOD to the incubation mixture results in an increased production of $\mathrm{OH}$-radicals. Since dismutation of superoxide generated by PHS and FP-12 produces $\mathrm{H}_{2} \mathrm{O}_{2}$ (eqn. A, Scheme 1), this $\mathrm{OH}$-radical formation is most probably caused by enhancement of the iron catalyzed Haber-Weiss reaction by elevated concentrations of $\mathrm{H}_{2} \mathrm{O}_{2}$ (eqn $\mathrm{B}$, Scheme 1). This is in agreement with the observation that incubations of FP-12 


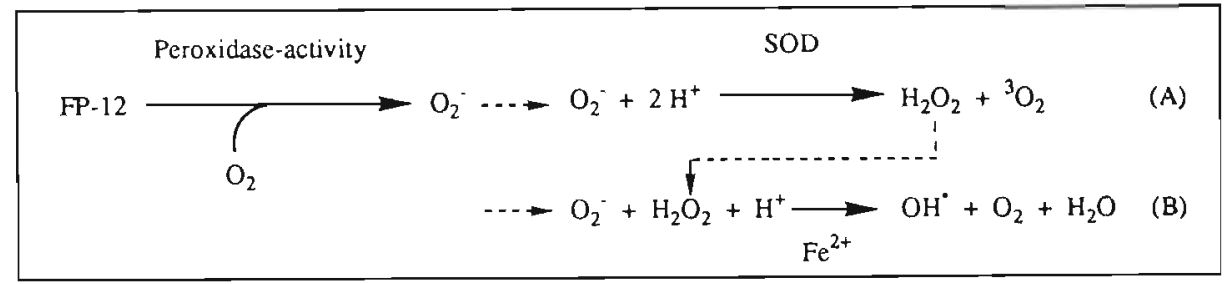

Scheme 1: Proposed reactions occurring in vitro after peroxidation of synthetic FP-12 by various peroxidases in presence of oxygen, resulting in the generation of superoxide. OH-radicals can be formed from superoxide by the iron catalyzed Haber-Weiss reaction (B). Dismutation of superoxide by SOD results in the formation of $\mathrm{H}_{2} \mathrm{O}_{2}$ (A) which in turn may enhance the Haber-Weiss reaction and therefore $\mathrm{OH}$-radical formation.

with HRP, $\mathrm{H}_{2} \mathrm{O}_{2}$ and DMPO or POBN result in a decreased superoxide signal after addition of SOD whereas no OH-spin adduct is found, since in these experiments DTPA was administered to block OH-radical formation via the Haber-Weiss route. It should be mentioned that the oxygen generated in the Haber-Weiss reaction might as well be in an electronically excited state (38). However, after OH-radical scavenging with tBA we did not observe induction of the TEMPO signal by singlet oxygen. Since the rate constant of trapping OH-radicals with TMP is unknown, it can not be excluded that $\mathrm{OH}$-radicals are more efficiently trapped.

Previously, it has been suggested that superoxide and $\mathrm{H}_{2} \mathrm{O}_{2}$ are not likely to induce biologically relevant DNA damage themselves $(39,40)$. Therefore, effects of $\mathrm{OH}$ radical scavenging on fecapentaene mutagenicity to Salmonella have been determined. Experiments using TBOOH and $\mathrm{COOH}$ in strain TA 104 have clearly demonstrated that mutagenicity of $\mathrm{OH}$-radicals can be reduced by adding $\mathrm{OH}$ radical scavengers. Although the mutagenic effect of FP-12 is never completely restrained, significant reduction of mutagenicity by scavenging $\mathrm{OH}$-radicals demonstrates the involvement of this oxygen species. The effect is found to be most convincing using both spintraps DMPO and TMP. This more pronounced mutagenicity reduction by DMPO as compared to effects of tBA and DMSO could be explained by the fact that DMPO traps OH-radicals as well as superoxide from which $\mathrm{OH}$-radicals are most probably originating. Also cytotoxicity can be diminished by radical scavenging, as determined in strain TA 100 , which indicates that fecapentaene-derived $\mathrm{OH}$-radicals are also involved in this process. Again, DMPO is found to be the most effective inhibiting compound. Since the eventually determined number of revertants integrates mutation and survival rates, the increased revertant scores induced in TA 100 by $\mathrm{tBA}$ in presence of FP- 12 might be the result of more effective reduction of cytotoxicity. 
Based on ESR measurements and the observation that mutagenicity of FP-12 can be reduced by trapping of $\mathrm{OH}$-radicals, we propose enzymatic peroxidation of FP12 to occur as indicated in Scheme 1. We show that FP-12 can be peroxidized to yield reactive oxygen species in vitro by various isolated peroxidases. No peroxidases have to be added to express fecapentaene mutagenicity in Salmonella; since fecapentaene mutagenicity can be (partially) attributed to fecapentaenederived $\mathrm{OH}$-radicals, it may be concluded that $\mathrm{OH}$-radicals are generated by peroxidation of FP-12 in Salmonella itself. Furthermore, the specificity of peroxidase activity is shown to be of little importance for FP-12 mediated generation of superoxide in vitro, and it is therefore well possible that the NAD(P)H peroxidase identified in Salmonella by Jacobson et al. (41), is involved in the intracellular activation of FP-12 during mutagenicity testing. Mutagenicity tests with addition of PHS or other peroxidases have not been conducted since exogenous generated oxygen radicals have been shown to result in cytotoxic effects rather than mutagenicity $(42,43)$.

Carcinogenicity tests of FP-12 in rats have shown only an insignificant effect after intrarectal administration, whereas i.p. injection of FP-12 in newborn mice revealed neoplasm formation in the lung, liver, glandular stomach and development of subcutaneous fibrosarcoma $(44,45)$. The results presented in this study suggest that this organ-specific carcinogenicity may result from tissue-specific peroxidase activity. PHS is known to be present in many mammalian cells and at relatively high concentrations in the lung, urinary bladder, kidney medulla and in platelets (46-49). Unfortunately, little is known about PHS concentrations in rodent colon as compared to other tissues, so no association with fecapentaene carcinogenicity in rats can be made. In human colonic epithelial cells, presence of peroxidative enzymes as PHS (50) has been reported. As a consequence, superoxide and $\mathrm{OH}$ radicals may be generated from fecapentaenes after cellular resorption. Kinetic consequences of the proposed three step reaction scheme for the expression of fecapentaene-carcinogenicity imply:

1. Cellular resorption of the fecapentaenes, which appears no problem due to their lipophilic nature;

2. Enzymatic peroxidation of fecapentaenes by PHS, resulting in efficient intracellular generation of superoxide;

3. Spontaneous or enzymatic dismutation of superoxide to form $\mathrm{H}_{2} \mathrm{O}_{2}$ and possibly singlet oxygen. It is interesting to mention that abnormalities in levels of cellular SOD have been reported in colon tumors $(51,52)$; and

4. Site-specific generation of OH-radicals near the DNA. Catalysis of this reaction by chromatin-bound iron has been proposed to play a key role in $\mathrm{H}_{2} \mathrm{O}_{2}$ I superoxide induced DNA damage (53).

Apart from a direct interaction with the genetic material, reactive oxygen species may interact with DNA repair, replication processes and induce nucleotide pool imbalances which indirectly cause genetic damage (54). In conclusion, it can be hypothesized that exposure to fecapentaenes may result in oxidative DNA damage in the bowel. However, it remains to be demonstrated whether or not fecapentaenes induce this type of DNA damage in vivo, and whether this damage is related to 
carcinogenic events. Toxicokinetic properties and stability of fecapentaenes under physiological conditions will have to be investigated in order to determine the possible risk for fecapentaene-induced carcinogenesis in other tissues high in peroxidative activity, like the lung, bladder and prostate (50).

\section{References}

1. Bruce, W.R., Baptista, J., Che, T., Furrer, R., Gingerich, J.S., Gupta, I. and Krepinsky, J.J. (1982) General structure of "fecapentaenes" the mutagenic substances in human faeces. Naturwissenschaften 69, 557-558.

2. Schiffman, M.H., Van Tassell, R.L., Andrews, A.W., Wacholder, S., Daniel, J., Robinson, A., Smith, L., Nair, P.P. and Wilkins T.D. (1989) Fecapentaene concentration and mutagenicity in 718 North American stool samples. Mutat. Res. 222, 351-357.

3. Hirai, N., Kingston, D.G., Van Tassell, R.L. and Wilkins, T.D. (1985) Isolation and structure elucidation of fecapentaenes-12, potent mutagens from human feces. $J$. Nat. Prod. 4, 622-630.

4. De Kok, T.M.C.M., Ten Hoor, F. and Kleinjans, J.C.S. (1991) Identification and quantitative distribution of eight analogues of naturally occurring fecapentaenes in human feces by high performance liquid chromatography. Carcinogenesis 12, 199205.

5. Lederman, M., Van Tassell, R.L., West, S.E., Ehrich, M.F. and Wilkins, T.D. (1980) In vitro production of human fecal mutagen. Mutat. Res. 79, 115-124.

6. Van Tassell, R.L., MacDonald, D.K. and Wilkins, T.D. (1982) Production of a fecal mutagen by Bacteroides spp. Infection and Immunity 3, 975-980.

7. Van Tassell, R.L., MacDonald, D.K. and Wilkins, T.D. (1982) Stimulation of mutagen production in human feces by bile and bile acids. Mutat. Res. 103, 233-239.

8. Van Tassell, R.L., Schram, R.M. and Wilkins, T.D. (1986) Microbial biosynthesis of fecapentaenes. In I. Knudsen (ed.) Genetic toxicology of the diet. Alan R. Liss, New York, pp 199-211.

9. Wilkins, T.D., Lederman, M., Van Tassell, R.L., Kingston, D.G. and Henion, J. (1980) Characterization of mutagenic bacterial product in human feces. Am. J. Clin. Nutr. 33, 2513-2520.

10. Kingston, D.G.I., Piccariello, D.T., Keyes, R.F., Van Tassell, R.L. and Wilkins, T.D. (1989) Isolation and structure elucidation of plasmalopentaene-12 the biological precursor of fecapentaene-12. Tetrahedron Lett. 30, 6665-6668.

11. Kingston, D.G.I., Van Tassell, R.L. and Wilkins, T.D. (1990) The fecapentaenes, potent mutagens from human feces. Chem. Res. Toxicol. 3, 391-400.

12. Van Tassell, R.L., Piccariello, T., Kingston, D.G., Wilkins, T.D. (1989) The precursors of fecapentaenes: Purification and properties of a novel plasmalogen. Lipids 24, 454-459.

13. Göggelmann, W., Maier, F.K. and Pfaendler, H.R. (1986) Mutagenicity of synthetic racemic fecapentaene-12. Mutat. Res. 174, 165-167.

14. Peters, J.H., Riccio, E.S., Stewart, K.R. and Reist E.J. (1988) Mutagenic activities of fecapentaene derivatives in the Ames/Salmonella test system. Cancer Lett. 39, 287296.

15. Venitt, S. and D. Bosworth (1988) The bacterial mutagenicity of synthetic all-trans 


\section{Chapter 6}

fecapentaene-12 changes when assayed under anaerobic conditions. Mutagenesis 3(2), 169-173.

16. Plummer, S.M., Grafstrom, R.C., Yang, L.L., Curren, R.D., Linnainmaa, K. and Harris C.C. (1986) Fecapentaene-12 causes DNA damage and mutations in human cells. Carcinogenesis 7(9), 1606-1609.

17. Curren, R.D., Putman, D.L., Yang, L.L., Haworth, S.R., Lawlor,T.E., Plummer, S.M. and Harris, C.C. (1987) Genotoxicity of fecapentaene-12 in bacterial and mammalian cell assay systems. Carcinogenesis 8, 349-352.

18. Dypbukt, J.M., Edman, C.C., Sundqvist, K., Kakefuda, T., Plummer, S.M., Harris, C.C., Grafström, R.C. (1989) Reactivity of fecapentaene-12 toward thiols, DNA, and these constituents in human fibroblasts. Cancer Res. 49, 6058-6063.

19. Hinzman, M.J., Novotny, C., Ullah, A. and Shamsuddin. M. (1987) Fecal mutagen fecapentaene- 12 damages mammalian colon epithelial DNA. Carcinogenesis 8(10), $1475-1479$.

20. Gupta, I., Suzuki, K., Bruce, W.R., Krepinsky, J.J. and Yates, P. (1984) A model study of fecapentaenes: mutagens of bacterial origin with alkylating properties. Science 225, 521-523.

21. De Wit, P.P., Van der Steeg, M. and Van der Gen, A. (1986) Remarkable electrophilic properties of the pentaenol ether system of fecapentaene-12. Tetrahedron Lett.,27 (51), 6263-6266.

22. Povey, A.C., Schiffman, M., Taffe, B.G. and Harris, C.C. (1991) Laboratory and epidemiologic studies of fecapentaenes. Mutat. Res. 259, 387-397.

23. Povey, A.C., Wilson, V.L., Zweier, J.L., Kuppusamy, P., O'Neil, I.K. and Harris, C.C. (1992) Detection by ${ }^{32} \mathrm{P}$-postlabelling of DNA adducts induced by free radicals and unsaturated aldehydes formed during the aerobic decomposition of fecapentaene- 12 . Carcinogenesis, 13, 395-401.

24. Levin, D.E., Hollstein, M., Christman, M.F., Schwiers, E.A. and Ames, B.N. (1982) A new Salmonella tester strain (TA 102) with A-T base pairs at the site of mutation detects oxidative mutagens. Proc. Natl. Acad. Sci. USA, 79, 7445-7449.

25. Shioya, M., Wakabayashi, K., Yamashita, K., Nagao,M. and Sugimura, T. (1989) Formation of 8-hydroxydeoxyguanosine in DNA treated with fecapentaene-12 an -14. Mutat. Res. 225, 91-94.

26. Lion, Y., Delmelle, M. and Van de Vorst, A (1976) New method of detecting singlet oxygen production. Nature, 263, 442-443.

27. Van Maanen, J.M.S., unpublished results.

28. De Wit, P.P., Van Schaik, T.A.M. and Van der Gen, A. (1984) A convenient synthesis of fecapentaene-12 by the Horner-Wittig reaction. Recl. Trav. Chim. Pays-Bas, 103, 369-370.

29. Kleinjans, J.C., Pluijmen, M.H., Hageman, G.J. and Verhagen, H. (1989) Stabilization and quantitative analysis of fecapentaenes in human feces, using synthetic fecapentaene-12. Cancer Letr. 44, 33-37.

30. Hageman, G., Kikken, R., Ten Hoor, F. and Kleinjans, J. (1988) Assessment of mutagenic activity of repeatedly used deep-frying fats. Mutat. Res., 204, 593-604.

31. Kanofsky, J.R. (1988) Singlet oxygen production from the peroxidase-catalyzed oxidation of indole-3-acetic acid. J. Biol. Chem., 263, 14171-14175.

32. Kanofsky, J.R. (1983) Singlet oxygen production by lactoperoxidase. J. Biol. Chem., 258, $5991-5993$.

33. Khan, A.U., Gebauer, P. and Hager, L.P. (1983) Chloroperoxidase generation of 
singlet $\Delta$ molecular oxygen observed directly by spectroscopy in the $1-$ to $1.6-\mu \mathrm{m}$ region. Proc. Nall. Acad. Sci. USA, 80, 5195-5197.

34. Khan, A.U. (1984) Myeloperoxidase singlet molecular oxygen generation detected by direct infrared electronic emission. Biochem. Biophys. Res. Communs., 122, 668-675.

35. Finkelstein, E., Rosen, G.M. and Rauckman, E.J. (1980) Spin trapping of superoxide and hydroxyl radical: Practical aspects. Arch. Biochem. Biophys., 200, 1-16.

36. Samuni, A., Blacks, C.D.V., Krishna, C.M., Malech, H.L. Bernstein, E.F. and Russo, A. (1988) Hydroxyl radical production by stimulated neutrophils reappraised. J. Biol. Chem. 263(27), 13797-13801.

37. Grover, T.A. and Piette, L.H. (1981) Influence of flavin and removal on the formation of superoxide by NADPH-cytochrome P-450 reductase: a spin-trap study. Arch. Biochem. Biophys. 212, 105-114.

38. Hamers, M.H. and Roos, D. (1985) Oxidative stress in human neurtorphilic granulocytes: Host defense and self-defense. In Sies H. (ed.) Oxidative stress, Academic press, London, pp 351-381.

39. Blok, J. and Loman, H. (1973) The effects of gamma-irradiation in DNA. Curr. Topics Radiat. Quart., 9, 165-245.

40. Lafleur, M.V.M. and Loman, H. (1986) Radiation damage to $\Phi X-174$ DNA and biological effects. Radiat. Environ. Biophys. 25, 159-173.

41. Jacobson, F.A., Morgan, R.W., Christman, M.F. and Ames, B.N. (1989) An alkyl hydroperoxide reductase from Salmonella typhimurium involved in the defense of DNA against oxidative damage. J. Biol. Chem. 264, 1488-1496.

42. Dahl, T.A., Midden, W.R. and Hartman, P.E. (1987) Pure singlet oxygen cytotoxicity for bacteria. Photochemistry and Photobiology 46, 345-352.

43. Dahl, T.A., Midden, W.R. and Hartman, P.E. (1988) Pure exogenous singlet oxygen: Nonmutagenicity in bacteria. Mutal. Res., 201, 127-136.

44. Ward, J.M., Anjo, T., Ohannesian, L. Keefer, L.K., Devor, D.E., Donovan, P.J., Smith, G.T., Henneman, J.R., Streeter, A.J., Konishi, N., Rehm, S. Reist, E.J., Bradford, W.W. and Rice, J.M. (1988) Inactivity of fecapentaene-12 as a rodent carcinogen or tumor initiator. Cancer Lett. 42, 49-59.

45. Weisburger, J.H. Jones, R.C., Wang, C.X., Backlund, J.Y.C., Williams, G.M., Kingston, D.G.I., Van Tassell, R.L., Keyes, R.F., Wilkins, T.D., De Wit, P.P., Van der Steeg, M. and Van der Gen, A. (1990) Carcinogenicity tests of fecapentaene-12 in mice and rats. Cancer Lett. 49, 89-98.

46. Sivarajah, K., Lasker, J.M. and Eling, T.E. (1981) Prostaglandin synthetase-dependent cooxidation of $( \pm$-benzo(a)pyrene-7,8-dihydrodiol by human lung and other mammalian tissues. Cancer Res. 41, 1834-1839.

47. Kolachana, P., Subrahmanyam, V.V., Eastmond, D.A. and Smith, M.T. (1991) Metabolism of phenylhydroquinone by prostaglandin (H) synthase: possible implications in o-phenylphenol carcinogenesis. Carcinogenesis 12, 145-149.

48. Sakata, T., Hasegawa, R., Johansson, S.L., Zenser, T.V. and Cohen, S.M. (1986) Inhibition by aspirin of $\mathrm{N}$-[4-(5-nitro-2-fury])-2-thiazolyl]formamide initiation and sodium saccharin promotion of urinary bladder carcinogenesis in male F344 rats. Cancer Res. 46, 3903-3906.

49. Christ, E.J., and Van Dorp, D.A. (1972) Comparative aspects of prostaglandin biosynthesis in animal tissues. Biochim. Biophys. Acta, 270, 537-545.

50. Flammang, T.J., Yamazoe, Y., Benson, R.W., Roberts, D.W., Potter, D.W., Chu, D.Z.J., Lang, N.P. and Kadlubar, F.F. (1989) Arachidonic acid-dependent peroxidative 


\section{Chapter 6}

activation of carcinogenic arylamines by extrahepatic human tissue microsomes. Cancer Res. 49, 1977-1982.

51. Nelson, R.L. (1988) Superoxide dismutase in cultured benign and malignant tumors of the colon. Basic Life Sci., 49, 699-702.

52. Hoffman, C.E.J., Webster N.R., Wiggins, P.A., Chisholm, E.M., Giles G.R. and Leveson, S.H. (1985) Free radical detoxifying systems in human colorectal cancer. Br. J. Cancer, 51, 127-129.

53. M. Larramendy, Mello-Filho, A.C. Lemme Martins, E.A., and Meneghine, R. (1987) Iron-mediated induction of sister-chromatid exchanges by hydrogen peroxide and superoxide anion. Mutat. Res., 178, 57-63.

54. Anderson, D. (1985) Induction of mutation and chromosome damage by excess bases and nucleosides. In: De Serres, F.J. (ed), Genetic consequences of nucleotide pool imbalance, Plenum Press, New York, pp. 283-295. 


\title{
Chapter 7
}

\section{Induction of oxidative damage to 2 '-deoxyguanosine, isolated and cellular DNA, and effects on the biological activity of single stranded $\phi X-174$ DNA by synthetic fecapentaene-12}

\author{
T.M.C.M. de Kok, D.M.F.A. Pachen, J.M.S. van Maanen, L.M. Maas, \\ M.V.M. Lafleur, E.J. Westmijze, F. ten Hoor and J.C.S. Kleinjans.
}

\begin{abstract}
Fecapentaene-12 (FP-12), a fecal unsaturated ether-linked lipid excreted by most human individuals in Western populations, has been found to be a potent genotoxin in mammalian cells. Its mechanism of genotoxicity may be mediated by oxygen radical induced DNA damage or by direct DNA alkylation, of which the relative importance remains to be determined. In the present study, induction of both oxidative and alkylating genetic damage by FP-12 has been investigated, as well as the biological inactivation of ss bacteriophage $\phi \mathrm{X}-174 \mathrm{DNA}$. It was shown that formation of 2'-deoxy-7,8-dihydro-8-oxoguanosine (8-oxodG), a marker for oxidative DNA damage, is induced dose dependently by FP-12 in 2 'deoxyguanosine $(\mathrm{dG})$. Enzymatic peroxidation of FP-12, which has been demonstrated to stimulate oxygen radical formation, was found to increase this oxidative effect. Further, it was demonstrated by application of radical scavengers, that production of superoxide as well as singlet oxygen may be involved in the induction of 8-oxodG. The effect of $\mathrm{OH}$-radical scavenging appeared to be less pronounced. In contrast to the effect of peroxidation of FP-12 on hydroxylation of dG, stimulated induction of 8-oxodG to ss DNA was found to be less pronounced and even absent in ds DNA. No induction of 8-oxodG was found after exposure of human skin fibroblasts to $60 \mu \mathrm{M}$ FP-12 for 3 hours. It was concluded that the induction of 8 -oxodG by FP-12 is determined by the accessibility of the guanine molecule rather than the rate of oxygen radical formation. Although free radical formation is known to be stimulated by enzymatic peroxidation of FP-12, the inactivation of $\phi \mathrm{X}-174$ DNA spontaneously induced by FP-12 was found to be reduced by application of peroxidases. This furthermore demonstrates that peroxidation of FP-12 accompanied by a high generation rate of reactive intermediates does not relate to increased induction of DNA damage. The fact that addition of radical scavengers show limited effects on the inactivation of $\phi X-174$ DNA suggests that oxidative DNA damage may only contribute for a
\end{abstract}


relatively minor degree to the genotoxic potential of FP- 12 .

The induction of alkylating DNA damage by FP-12 has been studied by ${ }^{32} \mathrm{P}$ postlabelling experiments. Preliminary results have shown that 5 additional spots of putative fecapentaene-DNA adducts are present after incubation of ss rat liver DNA with 1.6 mM FP-12. The formation of these putative fecapentaene adducts is found to be almost completely reduced by enzymatic peroxidation of FP-12. These results suggest that decreased inactivation of $\phi X-174$ DNA found after enzymatic peroxidation of FP-12 is a consequence of rapid peroxidation of reactive FP-12 decomposition products to less genotoxic end-products. This supports the hypothesis that direct DNA alkylation by FP-12 or FP-12 fragments, possibly aldehydes, is of major importance in fecapentaene genotoxicity as compared to the induction of oxidative DNA damage.

\section{Introduction}

Fecapentaenes, highly unsaturated enol ethers occurring in human feces, have been shown to possess high mutagenic capacity in various testing systems. In mammalian cells, synthetic fecapentaene-12 (FP-12) appeared capable of inducing sister chromatid exchanges, mutations and single strand breaks in DNA $(1,2)$, unscheduled DNA synthesis and cellular transformations (3). Based on this pronounced in vitro genotoxicity, fecapentaenes have been suggested to act as initiating agents in colorectal carcinogenesis. However, in vivo carcinogenicity experiments demonstrated predominantly negative results or neoplasm induction at sites other than the colon (4-9). Therefore, the role of fecapentaenes in colorectal carcinogenesis is still being discussed.

Studies on the mechanism of genotoxicity have indicated two different types of interaction of FP-12 with DNA. The first hypothesis involves a direct interaction between fecapentaenes and DNA, resulting in the formation of a covalent DNA adduct. This hypothesis is based on the observation of an addition product of FP12 to a nucleophilic compound, and the fact that fecapentaenes react as electrophilic carbocations with free thiols (10-12). Further, Povey et al. have recently shown the formation of unidentified adducted nucleotides after incubation of DNA or 2'deoxyguanosine-3'-monophosphate with FP-12 in 32P postlabelling experiments (I3). Putative fecapentaene-adducted nucleotides have also been demonstrated by using synchronous fluorescence spectrophotometry (4) and in DNA-binding studies with ${ }^{3}[\mathrm{H}]-\mathrm{FP}-12(14,15)$.

The second mechanism proposed for fecapentaene-genotoxicity suggests the generation of reactive oxygen species. This hypothesis is based on the observed formation of 2'-deoxy-7,8-dihydro-8-oxoguanosine (8-oxodG) during incubations of calf thymus DNA with FP-12 or fecapentaene-14 (FP-14) (16). Further indications are the oxidation of glutathione in FP-12-exposed human fibroblasts (12) and the mutagenicity of fecapentaenes to Salmonella typhimurium strains TA 102 and 104, both highly susceptible to oxidative damage $(3,17,18)$. Furthermore, it has been shown that mutagenicity of FP- 12 to these strains as well as to strain TA 100 can be reduced by addition of the oxygen radical scavengers 5,5-dimethyl-1-pyrroline N-oxide (DMPO), 2,2,6,6, tetramethylpiperidine (TMP), tert-butyl alcohol (tBA) and dimethylsulfoxide (DMSO) (19). Finally, electron 
spin resonance spectroscopy (ESR) has demonstrated that superoxide and hydroxyl radicals can be generated spontaneously or by enzymatic peroxidation of FP-12 at aerobic conditions $(13,19)$.

In this study, hydroxylation of $2^{\prime}$-deoxyguanosine $(\mathrm{dG})$ as well as single stranded (ss), double stranded (ds) and cellular DNA has been quantified in incubations with and without enzymatic peroxidation of FP-12 using HPLC with electrochemical detection (ECD). By determination of modulating effects by radical scavenging on the induction of 8 -oxodG, a marker for oxidative DNA damage, an attempt has been made to identify the reactive oxygen species involved. Studying the induction of DNA damage in relation with its effect on the biological activity of DNA might contribute to a better understanding of the processes involved in fecapentaene genotoxicity. Therefore, biological inactivation of ss bacteriophage ( $\phi X-174) \mathrm{DNA}$ by FP-12 has been quantified. This assay provides a relatively simple system as compared to the Salmonella mutagenicity test, in which biological consequences of interactions between naked ss phage DNA and FP-12 as well as FP-12-generated radicals can be studied without interference of cellular components. It has been demonstrated that $\phi X-174$ DNA may be inactivated by induction of both oxidative and alkylating damage (20-24). Finally, some preliminary results are presented of ${ }^{32} \mathrm{P}$ postlabelling experiments which have been conducted in order to detect specific DNA adducts induced by FP-12 or fecapentaene-decomposition fragments.

\section{Materials and methods}

Induction of 8-oxodG in $d G$ by FP-12

Solutions of synthetic FP-12 in ethanol/TEA (95:5), provided by Prof. A Van der Gen (25), were dried under a stream of nitrogen at $45^{\circ} \mathrm{C}$. Fecapentaenes were dissolved in $0.5 \mathrm{ml}$ of $2.7 \mathrm{mM} \mathrm{dG}$ (Sigma) diluted in $10 \mathrm{mM} \mathrm{Tris} / \mathrm{HCl}$ ( $\mathrm{pH} 7.5$ ), and incubated at $37^{\circ} \mathrm{C}$ for periods of 15 minutes up to 3 hours. Furthermore, 8-oxodG was quantified after peroxidation of FP-12 by 400 units of Lipoxidase (LO, Sigma), or 87 units prostaglandin $\mathrm{H}$ synthase (PHS, Sigma Co., St. Louis, MO, U.S.A.), with or without $0.2 \mathrm{mM}$ linoleate and $0.2 \mathrm{mM}$ arachidonate as cofactors respectively. All incubations using LO, contained $1 \mathrm{nM} \mathrm{H}_{2} \mathrm{O}_{2}$ whereas incubations with PHS contained $1 \mu \mathrm{M}$ haematine as additional cofactor. In order to study the involvement of superoxide in the formation of 8-oxodG, superoxide dismutase (SOD, Sigma; 120-360 units) and DMPO (10-30 mM; Aldrich, Steinheim F.R.G.) were added to the incubation mixtures. Since DMPO may react with both superoxide and $\mathrm{OH}$-radicals, results of these incubations will not discriminate between either intermediates. Therefore, effects of the more selective $\mathrm{OH}$-radical scavenger tBA (Aldrich; 105, 210, 315 or $630 \mathrm{mM}$ ) were also studied. The possible involvement of singlet oxygen in the formation of 8-oxodG was investigated by quenching singlet oxygen with sodium azide (SA, Sigma, 10-50 mM) or by conducting experiments in deuteriumoxide to prolong the life time of singlet oxygen (26). Cofactors, enzymes and substrates were all dissolved or diluted in $\mathrm{D}_{2} \mathrm{O}$ in order to maintain high purity, which appears necessary to obtain the 
desired effect $\left(\mathrm{D}_{2} \mathrm{O}>95 \%\right)$. In general, concentrations of scavengers, spintraps, enzymes and cofactors as well as incubation conditions are comparable to those applied in the study on radical formation described in chapter 6 . All incubations were performed in duplo.

\section{Induction of 8-oxodG in isolated DNA by FP-12}

Rat liver DNA was isolated applying methods described by Gupta $e t$ al. with minor modifications (27). Four $\mathrm{g}$ of rat liver was homogenized in $40 \mathrm{ml}$ PBS containing $1 \%$ SDS $/ 1 \mathrm{mM}$ EDTA. The homogenate was incubated with proteinase $\mathrm{K}\left(500 \mu \mathrm{g} / \mathrm{ml}\right.$; Boehringer Mannheim F.R.G.) for 30 minutes at $37^{\circ} \mathrm{C}$. After addition of $2 \mathrm{ml} 1 \mathrm{M}$ Tris/ $\mathrm{HCl}(\mathrm{pH} \mathrm{7.4),} \mathrm{the} \mathrm{homogenate} \mathrm{was} \mathrm{successively}$ extracted for 5 minutes with equal volumes of phenol, phenol/chloroform/isoamyl alcohol (25:24:1) and chloroform/isoamyl alcohol (24:1). After addition of $4 \mathrm{ml}$ of 5 $\mathrm{M} \mathrm{NaCl}, \mathrm{DNA}$ was precipitated with $2 \mathrm{vol}$ of $96 \%$ ethanol $\left(4^{\circ} \mathrm{C}\right)$. High molecular weight DNA was isolated and rinsed twice with $70 \%$ ethanol. After drying, DNA was dissolved in $8 \mathrm{ml}$ of $1.5 \mathrm{mM} \mathrm{NaCl} / 0.15 \mathrm{mM} \mathrm{Na}$ citrate / $1 \mathrm{mM}$ EDTA and treated during $30 \mathrm{~min}$ at $37{ }^{\circ} \mathrm{C}$ with 50 units / $\mathrm{ml}$ RNAse $\mathrm{T}_{1}$ and $100 \mu \mathrm{g} / \mathrm{ml}$ RNAse A. Excess of glycogen was removed by treatment with $500 \mu \mathrm{l}$ amylase $(1 \mathrm{mg} / \mathrm{ml}$; 30 min at $\left.37^{\circ} \mathrm{C}\right)$. This DNA solution was again extracted with chloroform/isoamyl alcohol (24:1) and precipitated, washed and dissolved as described above. Final DNA concentration was determined spectrophotometrically at $260 \mathrm{~nm}$ ( 1 unit $\mathrm{A}_{260}$ $=50 \mu \mathrm{g} \mathrm{ds} \mathrm{DNA} / \mathrm{ml}$ ). Single stranded DNA was obtained by denaturation of native DNA at $100{ }^{\circ} \mathrm{C}$ for 5 minutes and subsequent chilling in ice-water. Denaturation was checked by spectrophotometric measurement of the hyperchromic effect at $260 \mathrm{~nm}\left(1\right.$ unit $\mathrm{A}_{260}=40 \mu \mathrm{g}$ ss DNA $\left./ \mathrm{ml}\right)$.

Both ss and ds DNA $(350 \mu \mathrm{l} ; 650 \mu \mathrm{g} / \mathrm{ml})$ were incubated in duplo during 3 hours with $0,60 \mu \mathrm{M}$ and $1.6 \mathrm{mM}$ FP-12. Every hour, the solution was flushed with oxygen. Applying the same FP-12 concentrations and incubation conditions, the effect on the induction of 8-oxodG of peroxidation by PHS (87 units) and LO (400 units) was determined in presence of the appropriate cofactors. After incubation, peroxidative enzymes were removed after denaturation at $100{ }^{\circ} \mathrm{C}(3$ $\mathrm{min}$ ) by centrifugation. Supernatant was removed from the pellet and DNA was precipitated with 2 vol of $96 \%$ ethanol $\left(4{ }^{\circ} \mathrm{C}\right)$, washed twice with $70 \%$ ethanol and dissolved in $5 \mathrm{mM}$ Tris/ $\mathrm{HCl}(\mathrm{pH} \mathrm{7.4)}$.

\section{Induction of 8-oxodG in cellular DNA by FP-12}

Human skin fibroblast cultures were grown until confluency in Dulbecco's modified Eagle medium (DMEM), supplemented with $10 \%$ foetal calf serum (FCS). After trypsinization ( $0.05 \%$ trypsin in a solution containing: $2 \mathrm{mg} / \mathrm{l}$ phenol red, $6.9 \mathrm{mM} \mathrm{NaHCO}_{3}, 5.5 \mathrm{mM}$ Glucose, $5.4 \mathrm{mM} \mathrm{KCl}$ and $137 \mathrm{mM} \mathrm{NaCl}$ ) and washing with PBS ( $\mathrm{pH} 7.5$ ), approximately $12 \times 10^{6}$ cells were incubated in $6 \mathrm{ml}$ of FP-12 solutions in PBS ( $\mathrm{pH} 7.5$ ). The effect of FP-12 concentrations on the viability of the fibroblasts was established by determination of trypan blue exclusion. Cytotoxic effects were observed at concentrations higher than $100 \mu \mathrm{M}$. Therefore, DNA was isolated for analysis of oxidative DNA damage after incubation of fibroblasts with 0,6 and $60 \mu \mathrm{M}$ FP-12. These incubations were performed in triplo. No peroxidative enzymes were added since stimulation of extracellular radical generation would result in cytotoxic effects rather than increased cellular DNA 
damage. After pooling the incubated cell suspensions, DNA was isolated according to the methods described above.

\section{HPLC-analysis of 8-oxodG}

DNA solutions containing approximately $1 \mathrm{mg} / \mathrm{ml}$ in $33 \mathrm{mM}$ sodium acetate $(\mathrm{pH}$ 5.1) and $1 \mathrm{mM} \mathrm{ZnCl} 2$ were digested to deoxyribonucleotides by 2.5 units of nuclease Pl per $100 \mu \mathrm{g}$ DNA (Sigma). This solution was adjusted to $\mathrm{pH} 7.5$ by adding $0.33 \mathrm{vol}$ of $0.4 \mathrm{M}$ Tris $/ \mathrm{HCl}(\mathrm{pH} 7.5)$ and incubated for 30 minutes at $37^{\circ} \mathrm{C}$ with alkaline phosphatase (Sigma; 2.5 units / $100 \mu \mathrm{g}$ DNA). Analysis of 8-oxodG was performed on HPLC, applying a Gyncotech 480 high precision pump, coupled with a Spectroflow 783 programmable absorbance detector and an Antec electrochemical detector $(850 \mathrm{mV})$. As stationary phase a Supelcosil ${ }^{\mathrm{TM}}$ column (Supelco; $250 \times 4.6 \mathrm{~mm}$ ) was used in combination with a guard column (ODS pellicular $30 \times 2.1 \mathrm{~mm}$ ). Mobile phase consisted of $15 \%$ aqueous methanol containing $12.5 \mathrm{mM}$ citric acid, $25 \mathrm{mM}$ sodium acetate, $10 \mathrm{mM}$ acetic acid and 30 $\mathrm{mM} \mathrm{NaOH}$ and elution was performed at a flow of $1.0 \mathrm{ml} / \mathrm{min}$. For the analysis of 8-oxodG in incubations containing PHS, eluents with $10 \%$ methanol and a flow rate of $1.1 \mathrm{ml} / \mathrm{min}$ were used to provide optimal separation from an unknown contaminant present in the commercial enzyme preparation. Student t-test was used for the comparison of averaged hydroxylation ratios, calculated from duplo incubations and analyses.

\section{Inactivation of ss $\phi X-174 D N A$}

A suitable model for determining biological consequences of both oxidative and alkylating DNA damage induced by FP-12 is provided the $\phi \mathrm{X}-174$ inactivation assay, in which the reduction of the biological activity of bacteriophage DNA can be quantified. $\phi X-174$ DNA was isolated from wild type $\phi X-174$ bacteriophage according to Blok et al. (20). FP-12 was incubated with $1 \mu \mathrm{g} / \mathrm{ml}$ ss $\phi X-174$ DNA in presence and absence of PHS and LO. Using these low DNA concentrations and in view of the limited availability of the material, direct quantification of 8oxodG in $\phi X-174$ DNA was impossible. Therfore, in order to relate the induction of oxidative DNA damage directly to bacteriophage inactivation, mixtures of $\phi X-174$ DNA and ss rat liver DNA $(382 \mu \mathrm{g} / \mathrm{ml})$ were incubated. This enables simultaneous analysis of 8 -oxodG induction and bacteriophage inactivation. FP-12 concentration was $3 \mathrm{mM}$ in a volume of $500 \mu \mathrm{l}$. Incubations were performed at 37 ${ }^{\circ} \mathrm{C}$ during 48 hours. During the first 6 hours, reaction mixtures were oxygenated for 1 minute every hour. In order to determine interfering effects of radical scavenging on DNA inactivation, $10 \mathrm{mM}$ DMPO and $105 \mathrm{mM} \mathrm{tBA}$ have been added in parallel incubations. At various time intervals, $20 \mu \mathrm{l}$ samples were taken and diluted fifty-fold in ice cold $0.05 \mathrm{M}$ Tris- $\mathrm{HCl}(\mathrm{pH} 8.0$ ) to stop the reaction. Biological inactivation was determined after transfection of the phage DNA to freshly prepared Escherichia coli (AB1157) spheroplasts (23). After incubation of mixtures of $100 \mu \mathrm{l}$ DNA solution $(1 \mu \mathrm{g} / \mathrm{ml})$ and $100 \mu \mathrm{l}$ spheroplast suspension at $37{ }^{\circ} \mathrm{C}$ for 10 minutes, $0.8 \mathrm{ml}$ LBM (Luria Broth Medium with $10 \%$ (w/v) sucrose; $0.1 \%$ glucose; $0.2 \% \mathrm{MgCl}_{2}$ ) was added and the incubation was continued for 90 minutes. Bacteriophage yield was determined after addition of $4 \mathrm{ml}$ cold distilled water by plating with $E$. coli $C(20)$. The number of plaques provides a measure for the non-damaged part of the DNA. 
$32 P$ postlabelling analysis of FP-12 induced DNA-damage

Identical ss DNA samples as used for measurement of 8-oxodG content, were analysed for DNA damage induced by $1.6 \mathrm{mM} \mathrm{FP}-12$, with or without PHS, using $32 \mathrm{P}$ postlabelling techniques. DNA was digested to deoxynucleotide 3 'monophosphates (dNp's) at $37{ }^{\circ} \mathrm{C}$ during 4 hours, in $10 \mu \mathrm{l}$ reaction mixtures containing $1 \mu \mathrm{g}$ DNA, $0.2 \mathrm{U}$ of micrococcal nuclease (Sigma), $0.2 \mu \mathrm{g}$ spleen phosphodiesterase (Boehringer Mannheim), $20 \mathrm{mM}$ sodium succinate and $10 \mathrm{mM}$ $\mathrm{CaCl}_{2}$. After incubation, $10 \mu \mathrm{l}$ of water was added to the solutions and $3.4 \mu \mathrm{l}$ was used for postlabelling, which was performed in $10 \mu \mathrm{l}$ reaction mixtures containing: 540 pmol dNp's, 600 pmol [ $\gamma$-32P]ATP (Boehringer Mannheim) with a specific activity of $200 \mathrm{Ci} / \mathrm{mmol}, 0.2 \mathrm{U}$ polynucleotide kinase (Sigma), $10 \mathrm{mM}$ Bicine- $\mathrm{NaOH}$ (Merck, Darmstadt F.R.G.), $10 \mathrm{mM} \mathrm{MgCl}, 10 \mathrm{mM}$ dithiothreitol and $1 \mathrm{mM}$ spermidine ( $\mathrm{pH} 9.6$ ). After 40 minutes incubation at $37^{\circ} \mathrm{C}$, excess of ATP was destroyed by addition of $20 \mathrm{mU}$ apyrase (Sigma). After dilution with 10 volumes of water, $25 \%$ of the sample was incubated during 1 hour at $37{ }^{\circ} \mathrm{C}$ in a reaction mixture containing $0.5 \mu \mathrm{g} / \mu \mathrm{l}$ nuclease P1 (Boeringer Mannheim), $60 \mathrm{mM} \mathrm{NaAc}$ and $0.1 \mathrm{mM} \mathrm{ZnCl}_{2}$ (pH 5.0). Of this solution, $8 \mu \mathrm{l}$ was spotted on a PEI-cellulose thin layer for two dimensional chromatography with $0.6 \mathrm{M}$ ammonium formate $(\mathrm{pH}$ 3.5 ) in the first dimension, and saturated ammonium sulfate ( $\mathrm{pH} \mathrm{3.5)} \mathrm{in} \mathrm{the} \mathrm{second.}$ Paper-wicks were attached to the cellulose plates to improve separation.

\section{Results}

Induction of 8-oxodG in $d G$ by FP-12

Dose-response relationships between FP-12 concentrations and ratio of induced 8-oxodG / dG are given in Figure 1. The background level of 8-oxodG appears to be $1.5 \times 10^{-5} 8$-oxodG / dG. During 2 hours of incubation, this ratio increases four-

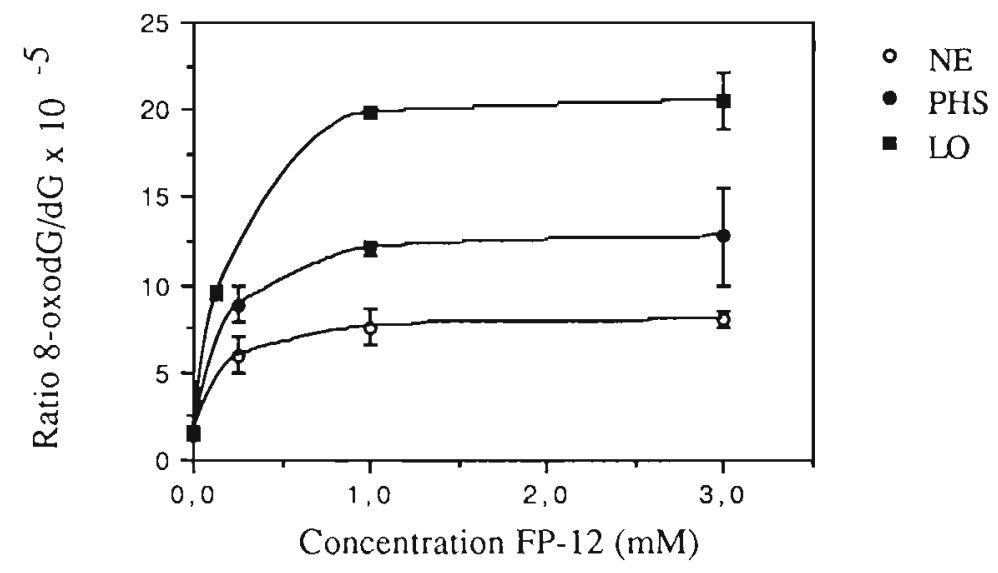

Fig. 1: Hydroxylation ratio of $\mathrm{dG}(2.7 \mathrm{mM})$ induced by synthetic FP-12 with or without enzymatic peroxidation at $37^{\circ} \mathrm{C}$ for 2 hours; SD calculated from duplo incubations and analyses. (NE: non-enzymatic; PHS: prostaglandin $\mathrm{H}$ synthase / haematine; LO: lipoxidase / $\mathrm{H}_{2} \mathrm{O}_{2}$ ). 
fold, reaching a maximum response at a concentration of $1 \mathrm{mM}$ synthetic FP- 12 . The fact that the dose-response curve reaches a plateau at $1 \mathrm{mM} \mathrm{FP}-12$ may be a consequence of the formation of micelles at this relatively high concentration of FP-12 in 100\% aqueous solutions. Enzymatic peroxidation of FP-12 by PHS as well as LO appears to enhance the hydroxylation of $\mathrm{dG}$. Since addition of $0.2 \mathrm{mM}$ linoleate or arachidonate results in elevated background levels of 8-oxodG (data not shown), further incubations have been performed without these two cofactors. No effects of PHS / haematine or $\mathrm{LO} / \mathrm{H}_{2} \mathrm{O}_{2}$ on the background level of 8-oxodG have been found.

The effects of SOD and DMPO are given in Figure 2, which shows that dismutation of superoxide and scavenging of both superoxide and OH-radicals may reduce the hydroxylation ratio. The effects of SOD after peroxidation with
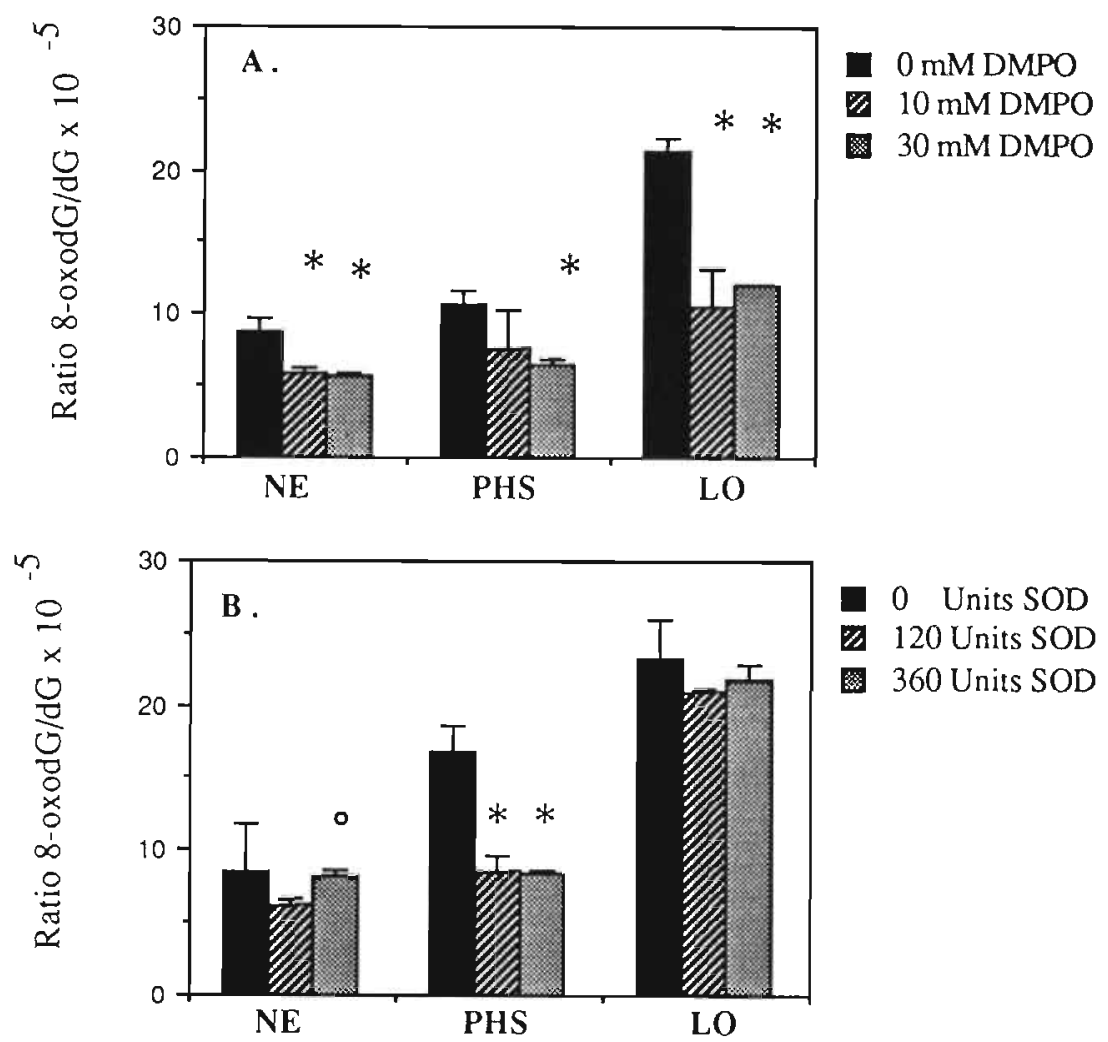

Fig 2: Effects of DMPO (A) and SOD (B) on hydroxylation ratio of dG (2.7 mM) induced by synthetic FP-12 (1.0 mM) with or without enzymatic peroxidation at $37^{\circ} \mathrm{C}$ for 2 hours; SD calculated from duplo incubations and analyses. (NE: non-enzymatic; PHS: prostaglandin $\mathrm{H}$ synthase / haematine; LO: lipoxidase $/ \mathrm{H}_{2} \mathrm{O}_{2}$ ).

* Significantly lower as compared to reference without DMPO/SOD.

o Significantly higher as compared to 120 units SOD. 
PHS and of $30 \mathrm{mM}$ DMPO appear to be statistically significant. However, the reducing effect of SOD on the hydroxylation ratio using $\mathrm{LO}$ as peroxidative enzyme appeared not significant. No effects of SOD and DMPO, with or without peroxidases and cofactors, have been found on the background level of 8-oxodG. As is shown in Figure 3, OH-radical scavenging with tBA has little effect on the hydroxylation ratio. The only significantly decreased hydroxylation ratio is found in incubations with LO for 3 hours and addition of $315 \mathrm{mM}$ of $\mathrm{tBA}$ as compared to $210 \mathrm{mM} \mathrm{tBA}$. The addition of $\mathrm{tBA}$ to incubations without peroxidases even increased hydroxylation ratios. This effect is not observed in the appropriate control incubations without FP-12. Addition of SA shows reduction of the hydroxylation ratio after incubation with both enzymes (Figure 4). This reduction is not seen without enzymatic peroxidation. No effect of SA has been found on
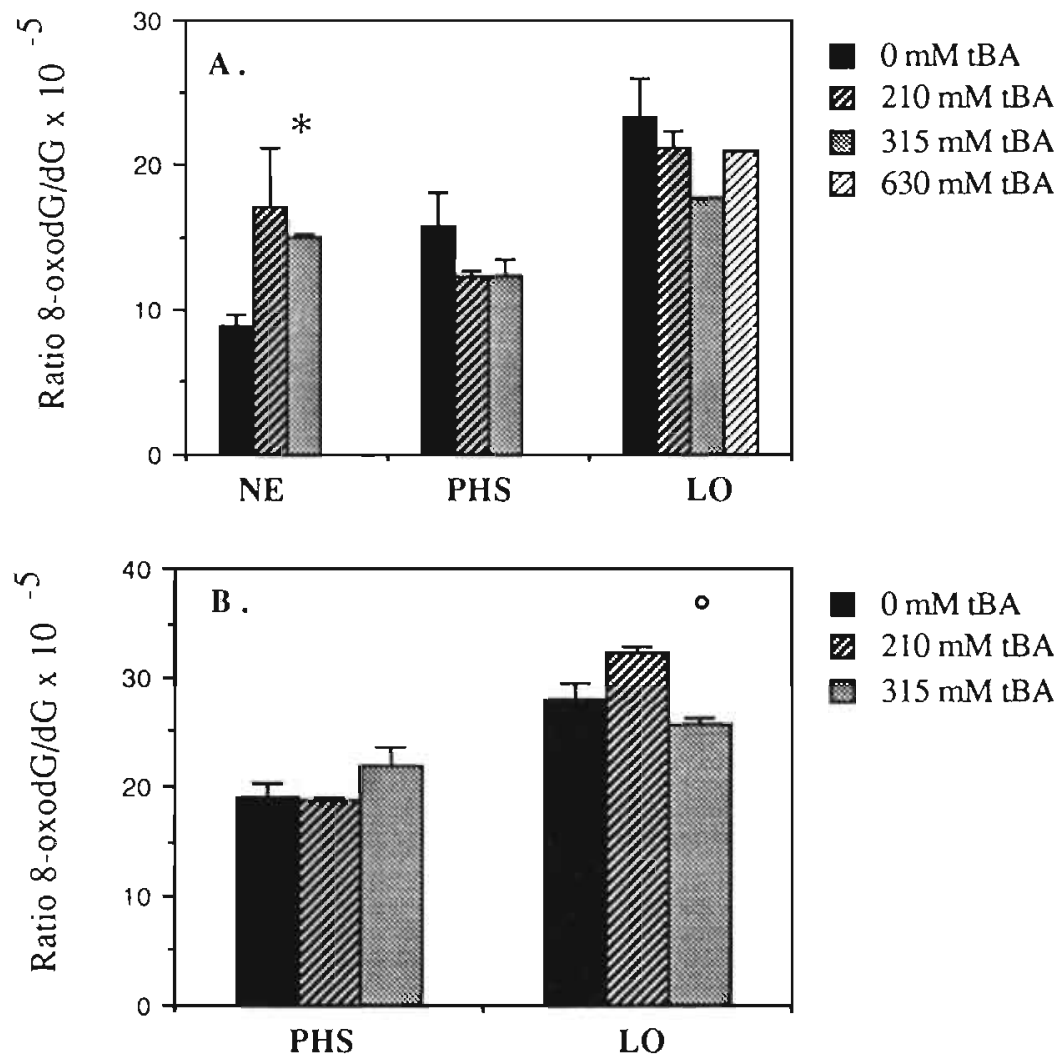

Fig 3: Effects of $\mathrm{tBA}$ on hydroxylation ratio of $\mathrm{dG}(2.7 \mathrm{mM})$ induced by synthetic FP- $12(1.0 \mathrm{mM})$ with or without enzymatic peroxidation at $37^{\circ} \mathrm{C}$ for 2 (A) or 3 hours (B); SD calculated from duplo incubations and analyses. (NE: non-enzymatic; PHS: prostaglandin $\mathrm{H}$ synthase/ haematine; LO: lipoxidase $/ \mathrm{H}_{2} \mathrm{O}_{2}$ ). * Significantly higher as compared to reference without tBA.

- Significantly lower as compared to $210 \mathrm{mM}$ tBA. 


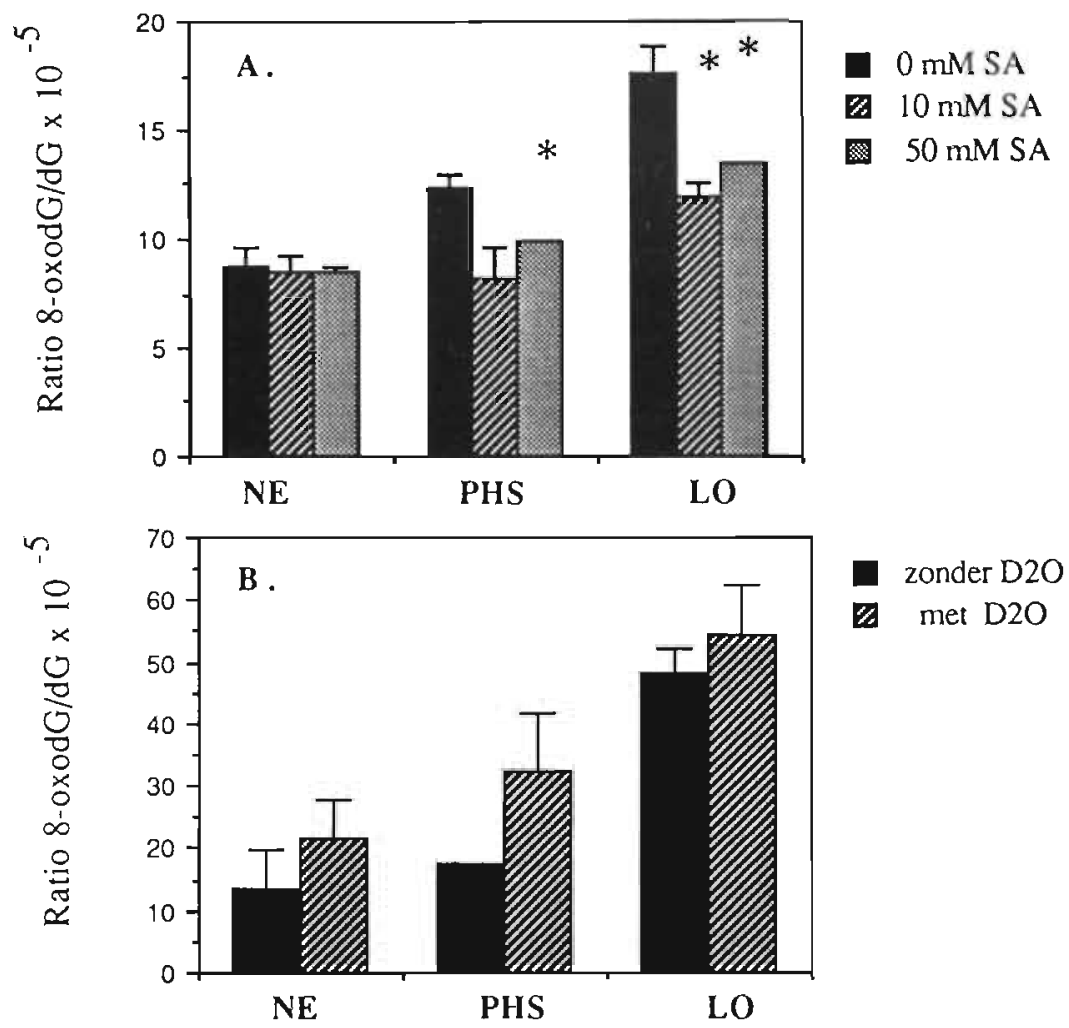

Fig 4: Effects of $\mathrm{SA}(\mathrm{A})$ and $\mathrm{D}_{2} \mathrm{O}(\mathrm{B})$ on hydroxylation ratio of $\mathrm{dG}(2.7 \mathrm{mM})$ induced by synthetic FP-12 (1.0 mM) with or without enzymatic peroxidation at $37^{\circ} \mathrm{C}$ for 2 hours; SD calculated from duplo incubations and analyses. (NE: non-enzymatic; PHS: prostaglandin $\mathrm{H}$ synthase / haematine; LO: lipoxidase $/ \mathrm{H}_{2} \mathrm{O}_{2}$ ).

* Significantly lower as compared to reference without SA.

background levels of 8-oxodG. In contrast to the effect of quenching singlet oxygen with SA, prolongation of the life-time of singlet oxygen by performing experiments in $\mathrm{D}_{2} \mathrm{O}$ shows a stimulation of $\mathrm{dG}$ hydroxylation (Figure $4 \mathrm{~b}$ ). However, due to relatively high variation, these effects are not statistically significant (Student t-test, $0.10>p>0.05$ ). It is concluded that both superoxide and singlet oxygen are involved in the FP-12 induced hydroxylation of dG.

Induction of 8-oxodG in isolated and cellular DNA by FP-12

The dose dependent induction of 8-oxodG by FP- 12 to ss and ds rat liver DNA is shown in Figure 5. Background levels of 8-oxodG in ss and ds rat liver DNA appear to be 3.9 and $3.6 \times 10^{-5} 8$-oxodG / dG, respectively. At low concentrations of $60 \mu \mathrm{M}$, significant elevation of 8-oxodG level as compared to the background 

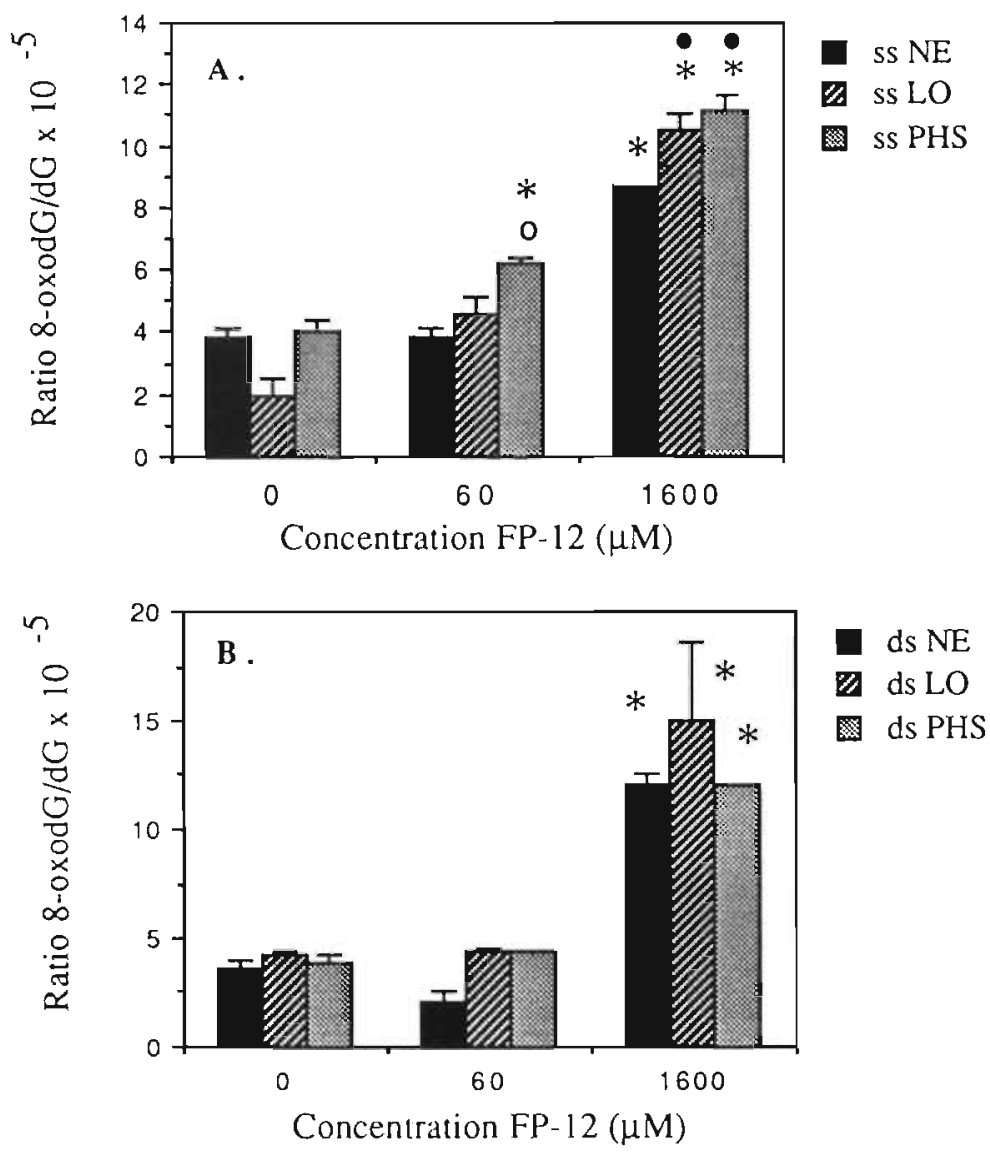

Fig. 5: Effect of enzymatic peroxidation by PHS and LO on the FP-12 induced 8oxodG levels in ss (A) and ds (B) rat liver DNA; SD calculated from duplo incubations and analyses. (NE: non-enzymatic; PHS: prostaglandin $\mathrm{H}$ synthase / haematine; $\mathrm{LO}$ : lipoxidase $/ \mathrm{H}_{2} \mathrm{O}_{2}$ ).

* Significantly higher as compared to the $0 \mu \mathrm{M}$ matching reference.

- Significantly higher as compared to the $60 \mu \mathrm{M}$ incubations NE and LO.

- Significantly higher as compared to the $1.6 \mathrm{mM}$ incubation NE.

has been found only in combination with PHS. At FP-12 concentrations of 1.6 $\mathrm{mM}$, significant increases of the hydroxylation ratios have been found in both ss and ds DNA, with and without enzymatic peroxidation. The combination of FP-12 and peroxidases appears to induce significantly more oxidative damage to ss DNA as compared to the effect of FP-12 spontaneously. In ds DNA however, this effect has not been established. Spontaneous induction 8-oxodG by $1.6 \mathrm{mM} \mathrm{FP-12}$ appeared to be significantly higher in ds DNA as compared to ss DNA $(\mathrm{p}<0.05)$. Viability of human fibroblasts after 3 hours incubation at concentrations of 0,6 
Fig 6: Hydroxylation ratio in DNA isolated from human skin fibroblasts after 3 hours of exposure to non-cytotoxic concentrations of FP-12; SD calculated from duplo HPLC-analyses.

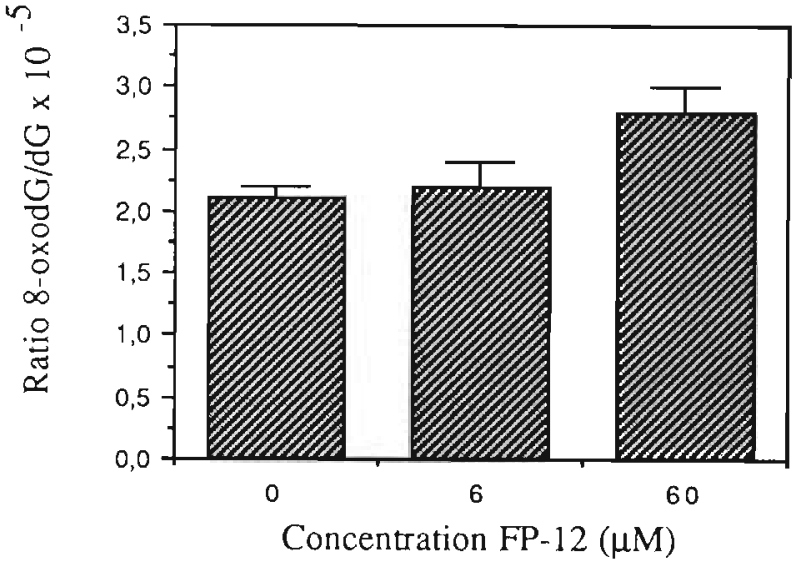

and $60 \mu \mathrm{M} \mathrm{FP}-12$, was found to be 90,87 and $77 \%$, respectively. As shown in Figure 6, no significant induction of 8-oxodG to cellular fibroblast DNA above the background ratio of $2.1 \times 10^{-5} 8$-oxodG / dG is found after 3 hours of incubation at these FP-12 exposure levels. These results indicate the accessibility of guanine residues is of major importance for the induction of oxidative DNA damage by FP12.

\section{Inactivation of ss $\phi X-174 D N A$}

The surviving fraction of bacteriophage DNA after incubation with FP-12 at various conditions is shown in Figure 7. Maximal inactivation of $\phi X-174$ DNA is found after 24 hours of incubation with FP-12 alone. The combination of FP-12 and both types of peroxidative enzymes result in comparable inactivation rates during the first 2 hours of incubation. However, after 6 to 24 hours, surviving fractions in incubations with peroxidases appear to be about 1 decade higher as compared to inactivation by FP-12 spontaneously. Addition of LA and AA as cofactors to incubations of $3 \mathrm{mM} \mathrm{FP-12}$ with LO and PHS respectively appeared to be of no influence; however, peroxidation of LA and AA in absence of FP-12 is

Fig 7: Surviving fraction of $\phi \mathrm{X}-174$ DNA, after incubation at $37^{\circ} \mathrm{C}$ with $3 \mathrm{mM}$ FP- 12 with and without enzymatic peroxidation. Reference incubations contain only LO or PHS.

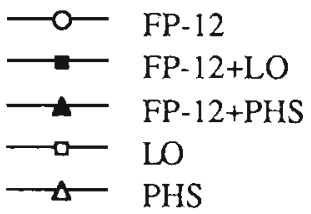

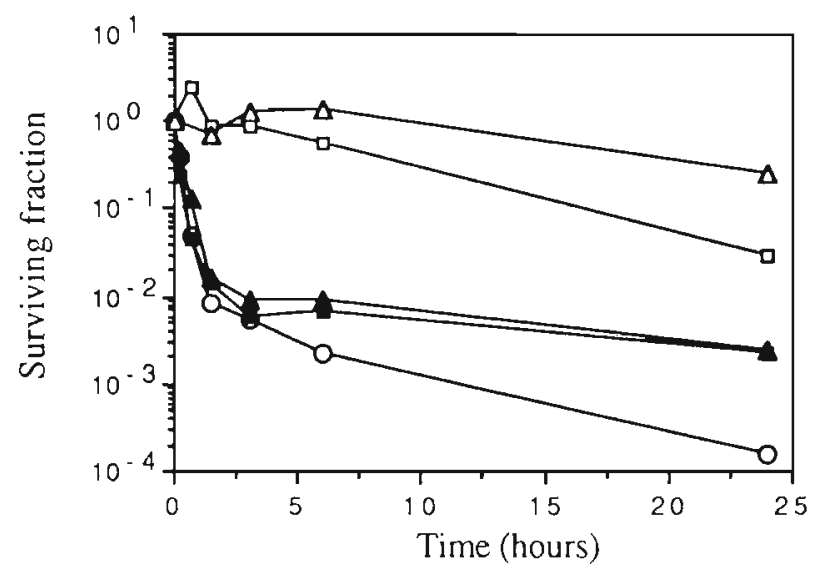




\section{Chapter 7}

also found to inactivate $\phi \mathrm{X}-174 \mathrm{DNA}$ (data not shown). Spontaneous inactivation of non-treated bacteriophage DNA during 24-48 hours appears to be minimal. Incubation of $1 \mu \mathrm{g} / \mathrm{ml} \phi X-174$ DNA with or without $382 \mu \mathrm{g} / \mathrm{ml}$ ss rat liver DNA and $3 \mathrm{mM}$ FP-12 results in well comparable inactivation curves as shown in Figure 7, indicating that relatively high concentrations of ss rat liver DNA do not interfere with the bacteriophage inactivation. Induced 8-oxodG levels were found to be $11.7 \pm 0.3$ and $16.8 \pm 0.4$ for incubations of ss DNA with $3 \mathrm{mM} \mathrm{FP}-12$ alone respectively $3 \mathrm{mM}$ FP- 12 in combination with LO.

Further, addition of tBA and DMPO shows a marginal reducing effect on $\phi \mathrm{X}-174$ DNA inactivation by FP-12 (Figure 8). In combination with either peroxidase, no additional effect is found. Apparently, scavenging of superoxide and OH-radicals does not result in efficient or complete reduction of DNA damage-induction by FP-12.

\section{$32 P$ postlabelling analysis of DNA-damage}

Autoradiograms of 32P-postlabelled digests of FP-12-treated ss DNA, with and without addition of PHS, as well as an non-treated DNA digest as reference are shown in Figure 9. Four additional spots of putative FP-12 adducts are separated by two-dimensional TLC of FP-12 exposed DNA. Furthermore, in a smear of background-activity, a fifth spot is located of 32P-labelled compounds which appears to migrate in the second dimension only. The digest of DNA treated with $1.6 \mathrm{mM}$ FP-
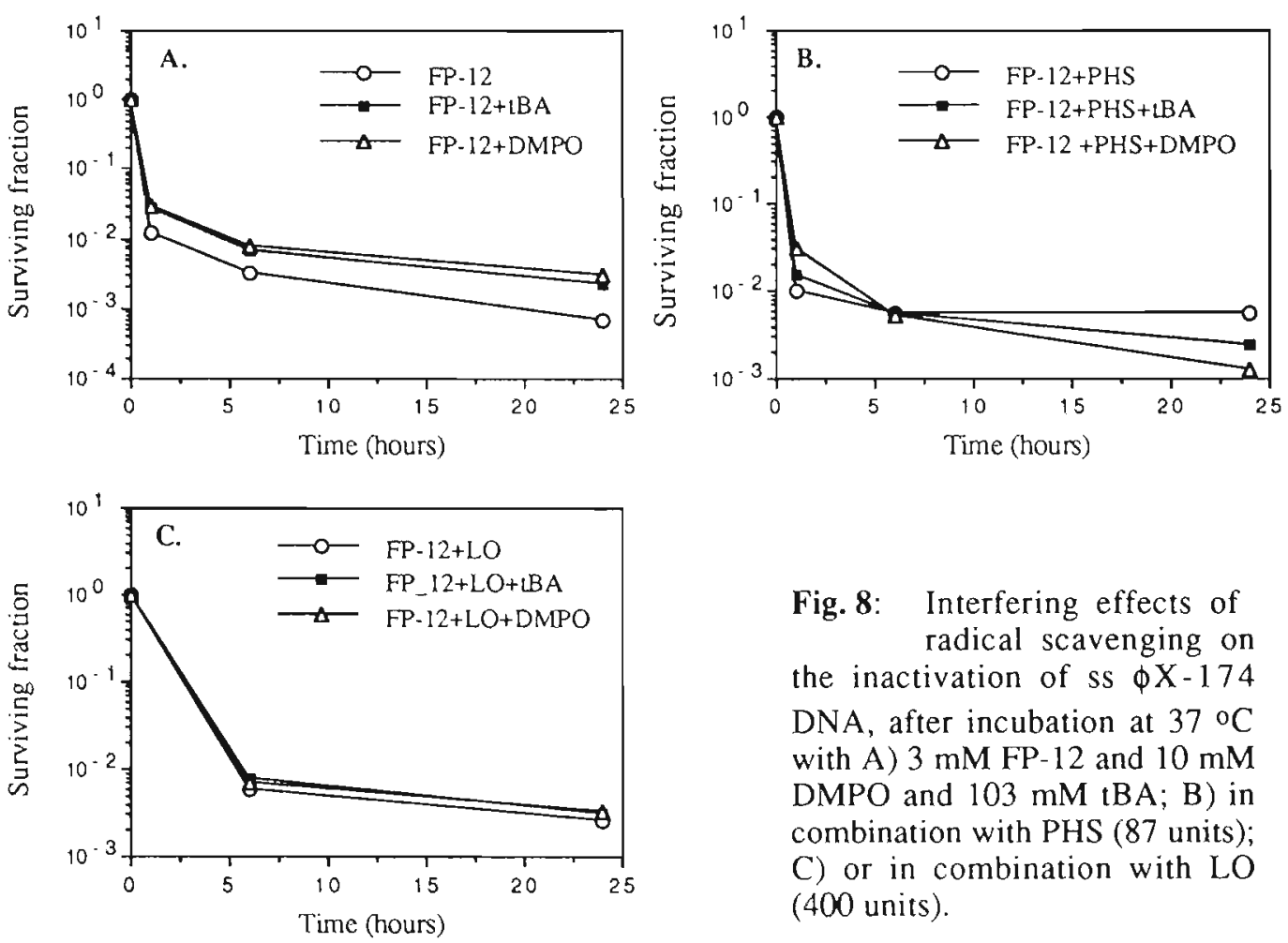

Fig. 8: Interfering effects of radical scavenging on the inactivation of ss $\phi \mathrm{X}-174$ DNA, after incubation at $37^{\circ} \mathrm{C}$ with A) $3 \mathrm{mM} \mathrm{FP}-12$ and $10 \mathrm{mM}$ DMPO and $103 \mathrm{mM} \mathrm{tBA} ; \mathrm{B})$ in combination with PHS (87 units); C) or in combination with LO (400 units). 

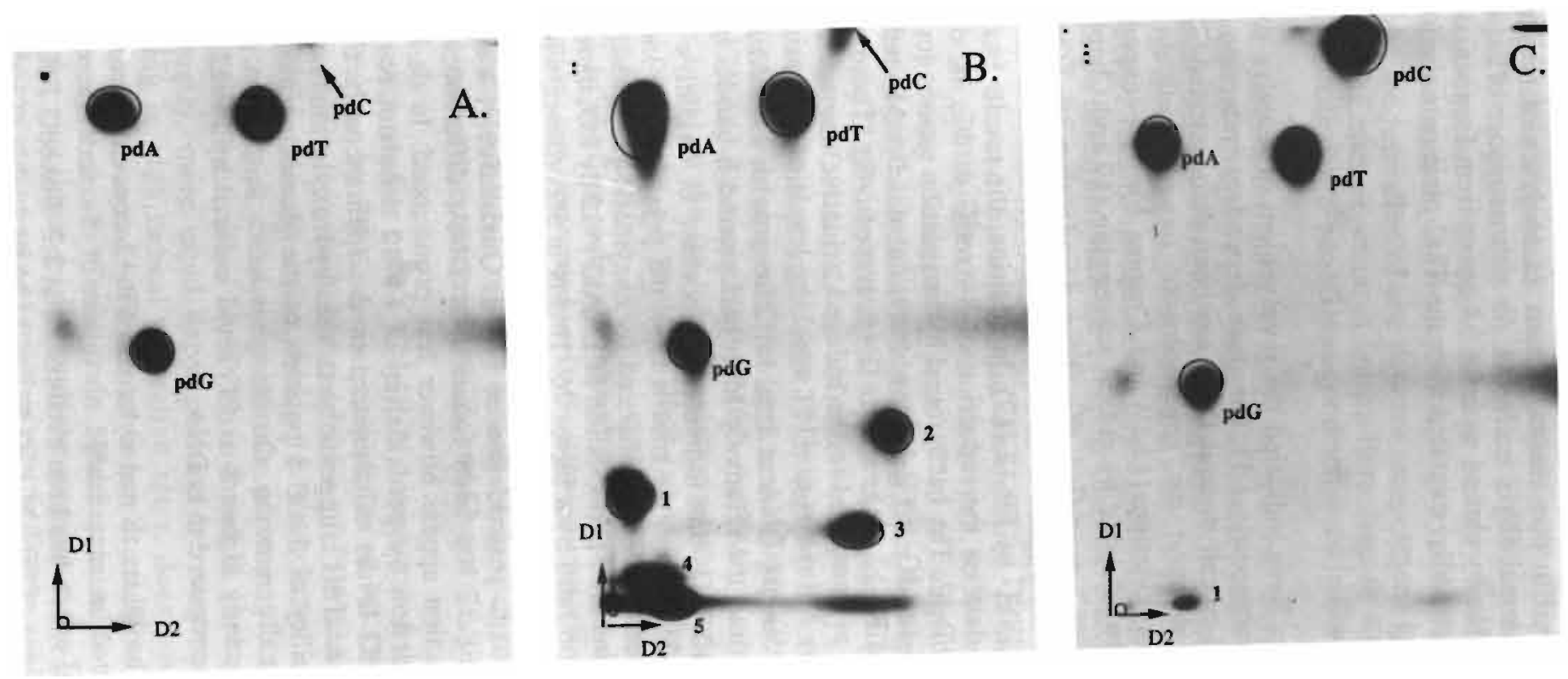

Fig. 9: Autoradiograms of 32P-postlabelled digests of ss rat liver DNA: A) untreated; B) treated with $1.6 \mathrm{mM} \mathrm{FP}-12$; C) treated with $1.6 \mathrm{mM} \mathrm{FP}-12$ in presence of PHS. X-ray films were exposed for $90 \mathrm{~min}$. 
12 in presence of PHS shows a comparable spot migrating in the second dimension, however with a much lower intensity. However, none of the other additional spots are observed in this autoradiogram. In analyses of non-treated DNA, no spots except the normal dNp's are found. As a consequence of improved mobility in the first dimension by elution with $0.6 \mathrm{M}$ ammonium formate, deoxycytidine 3'monophosphate (partially) migrated from the TLC-plate onto the wick.

\section{Discussion}

Results from several studies have indicated the involvement of reactive oxygen species in fecapentaene mutagenicity: 1) The dose dependent induction of 8oxodG by FP-12 and FP-14 to calf thymus DNA has been demonstrated (16); 2) ESR measurements demonstrated the generation of oxygen radicals both spontaneously and after peroxidation (13,19 and Chapter 6); 3) Fecapentaene mutagenicity can be partially inhibited by radical scavenging (19 and Chapter 6); 4) 32P-postlabelling of FP-12 modified dG showed induction of 8-oxodG, indicative for the induction of oxidative DNA damage (13); 5) GSH has been reported to be oxidized to GSSG by FP-12 (12). In addition, the results from this study provide quantitative data on the induction of 8-oxodG to dG, ss, ds and cellular DNA by synthetic FP-12. The background hydroxylation ratio is found to be elevated by a factor 5.5 for dG at FP- 12 concentration of $1.0 \mathrm{mM}$, and by a factor 2.2 and 3.0 at $1.6 \mathrm{mM} \mathrm{FP-12}$ for ss and ds DNA, respectively. These effects appear to be relatively low as compared to the induced oxidative damage to calf thymus DNA as reported by Shioya et al. (16), reaching levels of 2.9 residues / $10^{4} \mathrm{dG}$ upon incubation of $500 \mu \mathrm{g}$ DNA in $1 \mathrm{ml}$ for 2 hours with $1.6 \mathrm{mM}$ FP- 12 (after interpolation). Regarding the relatively high background 8-oxodG in calf thymus DNA of $0.2-0.3 / 10^{4} \mathrm{dG}$, this indicates an increase in oxidative DNA damage by a factor 10 to 15 . Further, the results from the present study indicate that oxidative damage to nucleosides is enhanced by enzymatic peroxidation of FP-12. Maximal effect is found after peroxidation of $1 \mathrm{mM} \mathrm{FP-12}$ by LO, increasing the background hydroxylation ratio by a factor 26 . This is in accordance with our earlier findings using ESR measurements, which indicated formation of reactive oxygen species after enzymatic peroxidation of FP-12. Qualitatively, a similar effect of peroxidation of FP-12 has been found in Ss DNA; differences with spontaneous 8-oxodG induction appear however less pronounced. In ds DNA, stimulation of radical induction by peroxidation of FP-12 does not result in significantly higher 8-oxodG levels as compared to the spontaneously FP-12induced oxidative damage. This suggests that the hydroxylation ratio is determined by the accessibility of the C- 8 position of the guanosine molecule rather than the rate of radical generation. On the other hand, this seems not in accordance with the significantly higher 8-oxodG level induced by FP-12 to ds DNA without LO or PHS as compared to ss DNA.

Exposure of human skin fibroblasts to non-cytotoxic FP-12 concentrations of 6 and $60 \mu \mathrm{M}$ has not resulted in measurable elevation of 8-oxodG levels as compared to the background which has been established at 2.28 -oxodG $/ 10^{5} \mathrm{dG}$. However, FP- 12 concentrations of $60 \mu \mathrm{M}$ also appear to be incapable of inducing 
8-oxodG in ds isolated DNA. On the other hand, induction of mutations, single strand breaks, sister chromatid exchanges and unscheduled DNA synthesis have been reported in fibroblasts after exposure at FP-12-levels varying form 0.4 to 20 $\mu \mathrm{M}$ (1). This suggests that the induction of these genotoxic effects by FP- 12 are not a consequence of oxidative damage but may result from other forms of DNA modification such as direct alkylation. This hypothesis is supported by a previous report on the formation of one putative fecapentaene DNA adduct detected by ${ }^{32} \mathrm{P}$ postlabelling after exposure of human fibroblasts to $40 \mu \mathrm{M}$ for 1 hour (13). In this study, formation of 8-oxodG was not determined in fibroblast DNA.

The mechanism for the generation of reactive oxygen species we previously proposed (19; Chapter 6 ), is largely confirmed by the present results on induction of oxidative damage to $\mathrm{dG}$ (Scheme 1, page 107). It has been shown that trapping of both superoxide and OH-radicals with DMPO, as well as dismutation of superoxide, results in decreased hydroxylation ratios. This is found with or without peroxidation, with the exception that the effect of SOD after peroxidation with LO appears not to be statistically significant. This may be explained by the fact that at relatively high superoxide concentrations induced by LO, hydrogen peroxide formed by enzymatic dismutation of superoxide stimulates the production of $\mathrm{OH}$-radicals and singlet oxygen, following the iron catalyzed HaberWeiss pathway (Scheme 1, page 107). A comparable effect of superoxide dismutation has been described in Chapter 6 for the signal intensity of $\mathrm{OH}$ radicals trapped by TMP. In contrast to the clear contribution by superoxide, the generation of $\mathrm{OH}$-radials as ultimate reactive oxygen species is not strongly supported. In contrast to the ESR measurements described in Chapter 6, in which $\mathrm{OH}$-radical scavenging with tBA appeared capable of reducing the signal intensity of the $\mathrm{OH}$-adducted spin traps DMPO and TMP, no significant reducing effect of tBA is found on the DNA hydroxylation ratios. On the other hand, quenching of singlet oxygen by SA reveals a clear reduction of induced 8-oxodG levels after enzymatic peroxidation. The involvement of singlet oxygen in the formation of 8oxodG is confirmed by the observed increase in hydroxylation ratios when incubations are performed in $\mathrm{D}_{2} \mathrm{O}$, although this effect appears only marginally significant. It has been suggested that the formation of singlet oxygen by the iron catalyzed Haber-Weiss reaction is more likely than groundstate oxygen, based on thermo-energetic considerations (26, and Chapter 6).

Inactivation studies on $\phi \mathrm{X}-174 \mathrm{DNA}$ demonstrated the induction of lethal DNA modifications by FP-12. Since peroxidation of FP-12 is known to induce radical formation, it was expected that addition of PHS and LO would result in higher inactivation ratios. However, during the first hours of incubation the inactivation is found to be equal without regard to the presence of LO or PHS, whereas after 24 hours total inactivation of FP-12 is found to be higher without peroxidation. Apparently, more rapid decomposition by enzymatic peroxidation of FP-12 resulting in high radical generation rates, does not relate to increased DNA inactivation as a consequence of induced oxidative DNA damage. This is in agreement with our findings on FP-12 induced 8-oxodG in ss and ds DNA indicating that the accessibility of the guanine in the DNA is of more importance than the generation rate of reactive intermediates. 
Assuming similar induction of 8-oxodG in ss rat liver DNA and $\phi X-174$ DNA, a calculation can be made of the contribution of 8 -oxodG in $\phi X$ inactivation. After subtraction of the background level of 8-oxodG, $3 \mathrm{mM} \mathrm{FP-12}$ was found to induce 7.78 -oxodG / $10^{5} \mathrm{dG}$. As one ss $\phi X-174$ DNA molecule contains approximately $1.35 \times 10^{3} \mathrm{dG}$, this indicates that $3 \mathrm{mM} \mathrm{FP}-12$ will induce 0.18 -oxodG / $\$ \mathrm{X}-174$ DNA molecule. On the other hand, we found inactivation of approximately 4 decades by 3 mM FP-12 which corresponds with 10 lethal hits / $\phi X-174$ DNA molecule. Assuming that each induced 8 -oxodG is lethal, for each inactivation 0.01 8 -oxodG is induced. This indicates a maximal contribution of 8 -oxodG in $\phi X-174$ DNA inactivation of $1 \%$. A comparable calculation in case of peroxidation of FP. 12 by LO indicates a maximal contribution of $1.6 \%$.

Furthermore, it appears that radical scavenging with both DMPO and tBA has only a limited effect on the inactivation of bacteriophage DNA. This indicates that the generation of oxygen radicals contributes only to a relatively minor extent to the FP-12 induced DNA damage and inactivation. Previously, this has also been suggested based on the fact that oxygen radical formation is also detected during the aerobic degradation of deca-2,4,6,8-tetraenal, a possible degradation product of FP-12 and a less potent mutagen $(13,28)$. However, radical scavenging in the Salmonella mutagenicity assay as described in chapter 6 , has been shown to reduce the mutagenic effect of FP-12 significantly (19). The observation that in these assays mutagenicity could not be reduced completely may be a consequence of inefficient or incomplete radical scavenging as well as the fact that FP-12 mutagenicity is only partially attributable to oxygen radical formation.

Apart from oxidative DNA damage, it has been suggested that fecapentaenes or aldehyde-type of fecapentaene-fragments formed during oxidative decomposition may interact with DNA to form covalent DNA adducts (10-15). Preliminary results of 32P-postlabelling analysis of FP- 12 induced DNA damage showed 5 additional spots of putative fecapentaene adducts which were not found in the reference DNA sample. This appears in agreement with the recent report of adducted nucleotides by Povey et al., using different chromatographic procedures (13). Enzymatic peroxidation of FP-12 by PHS is found to block the induction of extra spots almost completely. This might be explained by rapid peroxidation of FP- 12 or reactive decomposition products to less active end-products, providing a second explanation for the less pronounced inactivation of $\phi X-174$ DNA by FP-12 in combination with PHS or LO. The induction of fecapentaene-DNA adducts in ds isolated and cellular DNA are currently under investigation.

In summary, we found that FP-12 may induce both oxidative and alkylating damage to DNA. Although enzymatic peroxidation of FP-12 results in increased production of oxygen radicals and induction of 8 -oxodG in nucleosides, this appears not to relate to increased oxidative damage to native DNA or biological effects as demonstrated in $\phi \mathrm{X}-174$ inactivation experiments. Further, peroxidation of FP-12 has been shown to diminish the formation of putative fecapentaene-DNA adducts. This would imply that the presence of cellular peroxidative enzymes may provide protection against DNA damage induced by fecapentaenes. On the other hand, oxygen radicals and aldehydes formed during fecapentaene decomposition may also interfere with other cellular processes like DNA repair, or induce cell 
proliferation as a consequence of cytotoxic effects.

Since it appears that oxygen radicals and aldehyde-type of reactive intermediates are formed simultaneously, induction of both types of damage will have to be studied in vivo in relation to carcinogenic events. Further, the elucidation the chemical nature of the putative fecapentaene-DNA adducts may provide a specific marker for fecapentaene exposure, which may be a useful tool to establish the relevance of fecapentaenes in the etiology of colorectal cancer.

\section{References}

1. Plummer, S.M., Grafstrom, R.C., Yang L.L., Curren, R.D., Linnainmaa, K. and Harris, C.C. (1986) Fecapentaene-12 causes DNA damage and mutations in human cells. Carcinogenesis, 7, 1606-1609.

2. Schmid, E., Bauchinger, M., Braselmann, H., Pfaendler, H.R. and Göggelmann, W. (1987): Dose-response relationship for chromosome aberrations induced by fecapentaene-12 in human lymphocytes. Mutat. Res., 191, 5-7.

3 Curren, R.D., Putman, D.L., Yang, L.L., Hayworth, S.R., Lawlor, T.E., Plummer, S.M. and Harris, C.C. (1987) Genotoxicity of fecapentaene-12 in bacterial and mammalian cell assay systems. Carcinogenesis, 8. 349-352.

4. Shamsuddin, A.M., Ullah, A., Baten, A. and Hale, E. (1991) Stability of fecapentaene-12 and its carcinogenicity in F-344 rats. Carcinogenesis, 12, 601-607.

5. Vaughan, D.J., Furrer, R., Baptista, J. and Krepinsky, J.J. (1987) The effect of fecapentaenes on nuclear aberrations in murine colonic epithelial cells. Cancer Lett., 37, 199-203.

6. Hinzman, M.J., Novotney, C., Ullah, A. and Shamsuddin, A.M. (1987) Fecal mutagen fecapentaene- 12 damages mammalian colon epithelial DNA. Carcinogenesis, 8, 1475-1479.

7. Ward, J.M., Anjo, T., Ohannesian, L. Keefer, L.K., Devor, D.E., Donovan, P.J., Smith, G.T., Henneman, J.R., Streeter, A.J., Konishi, N., Rehm, S. Reist, E.J., Bradford, W.W. and Rice, J.M. (1988) Inactivity of fecapentaene-12 as a rodent carcinogen or tumor initiator. Cancer Lett. 42, 49-59

8. Devor, D.E., Henneman, J.R., Keefer, L.K., Logsdon, D.L., Rice, J.M., Streeter, A.J. and Ward, J.M. (1991) Carcinogenicity study of fecapentaene-12 diacetate on skin painting in SENCAR mice. Cancer Lett., 56, 11-15.

9. Weisburger, J.H. Jones, R.C., Wang, C.X., Backlund, J.Y.C., Williams, G.M., Kingston, D.G.I., Van Tassell, R.L., Keyes, R.F., Wilkins, T.D., De Wit, P.P., Van der Steeg, M. and Van der Gen, A. (1990) Carcinogenicity tests of fecapentaene-12 in mice and rats. Cancer Lett. 49, 89-98.

10. De Wit, P.P., Van der Steeg, M. and Van der Gen, A. (1986) Remarkable electrophilic properties of the pentaenol ether system of fecapentaene-12. Tetrahedron letters, 27(51), 6263-6266.

11. Gupta, I., Suzuki, K., Bruce, W.R., Krepinsky, J.J. and Yates, P. (1984) A model study of fecapentaenes: mutagens of bacterial origin with alkylating properties. Science 225, 521-523.

12. Dypbukt, J.M., Edman, C.C., Sundqvist, K., Kakefuda, T., Plummer, S.M., Harris, C.C. and Grafström, R.C. (1989) Reactivity of fecapentaene-12 toward thiols, DNA and these constituents in human fibroblasts. Cancer Res, 49, 6058-6063.

13 Povey, A.C., Wilson, V.L., Zweier, J.L., Kuppusamy, P., O'Neill, I.K. and Harris, C.C. (1992) Detection by ${ }^{32} \mathrm{P}$-postlabelling of DNA adducts induced by free radicals and unsaturated aldehydes formed during the aerobic decomposition of tecapentaene- 12 . 
Carcinogenesis, 13, 395-401.

14. Povey, A.C., Plummer, S.M., Grafstrom, R.C. and Harris, C.C. (1990) Genotoxic mechanisms of fecapentaene-12 in human cells. in Pariza, M.W., Aeschbacher, H.W., Felton, J.S. and Sato, S. (Eds.) Mutagens and Carcinogens in the Diet, Wiley-Liss, Chichester, pp. 155-166.

15 Povey, A.C., Schiffman, M., Taffe, B.G. and Harris, C.C. (1991) Laboratory and epidemiologic studies of fecapentaenes. Mutat. Res. 259, 387-397.

16. Shioya, M., Wakabayashi, K., Yamashita, K., Nagao,M. and Sugimura, T. (1989) Formation of 8-hydroxydeoxyguanosine in DNA treated with fecapentaene-12 an -14. Mutat. Res. 225, $91-94$.

17. Göggelmann, W., Maier, F.K. and Pfaendler, H.R. (1986) Mutagenicity of synthetic racemic fecapentaene-12. Mutat. Res. 174, 165-167.

18. Levin, D.E., Hollstein, M., Christman, M.F., Schwiers, E.A. and Ames, B.N. (1982) A new Salmonella tester strain (TA 102) with A-T base pairs at the site of mutation detects oxidative mutagens. Proc. Natl. Acad. Sci. USA, 79, 7445-7449.

19. De Kok, T.M.C.M., Van Maanen, J.M.V., Lankelma, J., Ten Hoor, F. and Kleinjans, J.C.S. (1992) Electron spin resonance spectroscopy of oxygen radicals generated by synthetic fecapentaene- 12 and reduction of fecapentaene mutagenicity to Salmonella typhimurium by hydroxyl radical scavenging. Carcinogenesis, 13, 1249-1255.

20. Blok, J. Luthjens, L.H. and Roos, A.L.M. (1967) The radiosensitivity of bacteriophage DNA in aqueous solution. Radiat. Res., 30,468-482.

21. Mans, D.R.A, Lafleur, M.V.M., Westmijse, E.J., Van Maanen, J.M.S., Van schaik, M.A., Lankelma, J., Retel, J. (1991) formation of different reaction products with single and double stranded DNA by the ortho-quinone and the semi-quinone from radical of etoposide (VP-16-213). Biochem. Pharmacol. 42, 2131-2139.

22. Van de Poll, M.L.M., Lafleur, M.V.M., Van Gog, F., Vrieling, H. and Meerman, J.H.N. (1992) N-acetylated and deacetylated four-pairs-fluoro-4-aminobiphenyl and 4amino biphenyl adducts differ in their ability to inhibit DNA replication of single stranded and M13 in vitro and of single stranded $\phi X-174$ in Escherichia coli. Carcinogenesis, 13, 715-758.

23. Lutgerink, J.T., Retel, J. and Loman H. (1984) Effects of adduct formation on the biological activity of single- and double-stranded Phi-X174 DNA, modified by Nacetyl-2-aminofluorene. Biochem. Biophys. Acta,781, 81-91.

24. Van Maanen, J.M.S., Lafleur, M.V.M., De Ruiter, C., Kootstra, P.R., Van den Akker, E., Pappie, D., De Vries, J., Retel, J. and Pinedo, H.M. (1988) Effects of the ortho-quinone and catechol of the antitumor drug VP-16-213 on the biological activity of single-stranded and double-strande $\$$ X174 DNA. Biochem. Pharmacol., 3579-89.

25. De Wit, P.P., Van Schaik, T.A.M. and Van der Gen, A. (1984) A convenient synthesis of fecapentaene- 12 by the Homer-Wittig reaction. Recl. Trav. Chim. Pays-Bas, 103, 369-370.

26. Hamers, M.H. and Roos, D. (1985) Oxidative stress in human neurtorphilic granulocytes: Host defense and self-defense. In Sies H. (ed.) Oxidative stress, Academic press, London, pp 351-381.

27. Gupta, R.C. (1984) Nonrandom binding of the carcinogen N-hydroxy-2acetylaminofluorene to repetitive sequences of rat liver DNA in vivo. Proc. Natl. Acad. Sci., 81, 6943-6947.

28. Gupta, I., Suzuki, K., Bruce, W.R., Krepinsky, J.J. and Yates, P. (1984) A model study of fecapentaenes: mutagens of bacterial origin with alkylating properties. Science, 225, $521-523$. 


\section{Chapter 8}

\section{General discussion}

\subsection{Fecapentaene exposure as possible risk factor for colorectal cancer}

In the preceding Chapters of this thesis, studies have been described in which an attempt is made to establish a possible relationship between fecapentaene excretion and risk for colorectal cancer. The main reasons for studying fecapentaenes as a relevant factor in colorectal carcinogenesis have been discussed in Chapter 1 and can be summarized as follows:

1. Synthetic fecapentaene-12 (FP-12) is found to be a highly potent mutagen in various types of genotoxicological testing systems with prokaryotic as well as human or other mammalian cells (1-10).

2. Fecapentaenes are shown to be excreted by $80-90 \%$ of Caucasian individuals on typical Western diets (11-13).

3. Median fecapentaene excretion levels have been demonstrated to vary between 500 and $1000 \mu \mathrm{g} / \mathrm{kg}$ wet feces, and may amount up to scveral $\mathrm{mg} /$ $\mathrm{kg}$ wet feces in some individuals. This implicates that the colorectal epithelium may be continuously exposed to relatively high concentrations of compounds with a mutagenic potential comparable to that of several known carcinogens $(7,11-17)$.

4. FP-12 was found to be carcinogenic to newborn mice (17), although in several other studies FP-12 failed to induce colon tumors in rodents after intrarectal application $(9,18-20)$.

Whether fecapentaenes are involved in the initiation of colorectal cancer has been studied by two different ways. In an epidemiological approach, an attempt is made to relate fecapentaene excretion to the consumption of "high risk" diets and the occurrence of benign bowel neoplasia. Further, correlations between diet and fecapentaene excretion have been determined in order to identify specific nutrients which are of relevance in fecapentaene excretion and thereby may possibly influence fecapentaene-mediated risk for colorectal cancer. The second approach concentrates on the elucidation of the mechanism of fecapentaene genotoxicity, which may result in a better understanding of the processes that are possibly involved in fecapentaene-induced transformation of colonic epithelial cells. 


\subsection{Epidemiological aspects of fecapentaene excretion}

\section{Analysis of fecapentaene excretion and fecal mutagenicity}

In order to study epidemiological aspects of fecapentaene excretion, a reliable quantitative method for fecapentaene analysis in feces has been developed. In Chapter 2, an extraction procedure has been described based on rigorous homogenization of feces with triethylamine-stabilized dichloromethane as extraction solvent. Compared to other methods frequently used for fecapentaene analysis in feces such as shaking at room temperature or using diethylether or acetone for extraction in combination with BHT for fecapentaene stabilization (21-24), this method was found to result in significantly higher extraction recoveries of spiked synthetic FP-12, which amount up to $78 \%$. As suggested in Chapter 4, relatively low recovery may be a consequence of the strong fecapentaene-binding capacity of fiber material present in feces, which hampers maximal fecapentaene recovery unless using our more rigorous extraction method. Furthermore, a gradient elution HPLC-analysis for fecapentaene quantification has been described using photodiode array detection for peak identification. This analysis was found to separate at least 8 different fecapentaene analogues as well as putative fecatetraenes and fecahexaenes. Identification of these compounds was based on comparison of UV spectra and chromatographic characteristics. Additionally, two suggested isomers (referred to as FP(13.2) and FP(13.5), based on retention times in the analytical system described in Chapter 2) of all-trans FP$12[\mathrm{FP}(14.0)]$ were found to have identical mass spectra, strongly suggesting that these natural compounds are indeed geometrical isomers of FP-12. Mass spectrometric analyses of $\mathrm{FP}(17.7)$ and $\mathrm{FP}(18.2)$, presumably two geometrical isomers of FP-14, remain to be performed. Furthermore, the exact chemical structure of $\mathrm{FP}(10.9), \mathrm{FP}(12.2)$ and $\mathrm{FP}(19.5)$, additional compounds showing the characteristic pentaene UV absorption spectra, still has to be elucidated. Since it has been demonstrated that the stability of FP-12 and FP-14 is not comparable (25), and kinetics in the bowel may also vary between different fecapentaene analogues, in situ genotoxic effects may not be the same for all separate fecapentaene forms. Furthermore, sufficiency of fecal precursor levels for synthesis of FP-12 and FP-14 may require distinct dietary habits as well as bacterial or human metabolic activity. Therefore, it seems indicated to quantify all fecapentaene analogues separately in studies correlating fecapentaene excretion to risk for colorectal cancer or intake of specific dietary factors.

Application of the described extraction procedure in order to analyse fecal mutagenicity to Salmonella typhimurium TA 100 was evaluated in two different populations as described in Chapter 2 and 3. These analyses showed that mutagenicity was considerably lower as hypothesized on fecapentaene content. As a consequence, no significant correlations between fecal mutagenicity and extracted fecapentaene concentrations could be established. Furthermore, it was found that fecal dichloromethane extracts were capable of reducing the mutagenic potential of synthetic FP-12. These results indicate that antimutagenic substances which interfere in the Salmonella mutagenicity assay are present in partially purified fecal dichloromethane extracts. Moreover, fecal dichloromethane extracts containing highly cytotoxic fecapentaene concentrations were found to be moderately mutagenic without any signs of cytotoxicity. Since studies on the 
mechanism of fecapentaene genotoxicity described in Chapter 6 and 7 demonstrated the generation of free radicals by FP-12, it can be suggested that both mutagenic and cytotoxic effects are decreased by co-extracted radical scavengers. Naturally occurring anti-oxidants like tocopherols and ascorbic acid may obviously be present in these extracts. Further, other fecal compounds like linoleic and oleic acid, have been shown to possess antimutagenic capacity in the Salmonella mutagenicity assay (26). Apart from organic extracts, the mutagenic potential of aqueous extracts has been evaluated in Chapter 3. It was found that aqueous extracts of fecapentaene-containing feces showed no mutagenic activity. HPLC-analysis further showed that these extracts do not contain detectable fecapentaene concentrations. This implies that fecal mutagenicity determined in both aqueous and organic feces extracts, is not a reliable marker for fecapentaene excretion, and that results from fecal mutagenicity studies using such preparations can not be interpreted as indirect measurement of fecal fecapentaene content (2732).

\section{Fecapentaene excretion in groups at different risk for colorectal cancer}

As discussed in Chapter 1, the search for etiological factors in colorectal cancer has indicated that dietary habits strongly relate to the occurrence of colon carcinoma. Generally, typical Western diets rich in animal fat and protein and with low fiber content, have been associated with increased risk (36-43). On the other hand, vegetarian dietary patterns with high fiber (37-41) and low intake of animal fat have been suggested to protect against colorectal cancer (40-44). Therefore, fecapentaene analysis as described and evaluated in Chapter 2, has been applied to feces from habitual vegetarians and omnivores in order to compare fecapentaene excretion levels in these populations at different risk for developing colorectal cancer. Although it appears that fecal mutagenicity is not a reliable index for fecapentaene excretion, our initial hypothesis that vegetarians excrete lower levels of fecapentaenes as compared to omnivores, was also based on the observation that vegetarians excrete less mutagenic feces $(26,28-30,32,42-44)$. It was furthermore assumed that high fecal fecapentaene levels correspond with increased intracellular exposure of colon epithelium to these putative initiators. In contrast, the results described in Chapter 3 showed that vegetarians are found to excrete significantly higher concentrations of total fecapentaenes as well as concentrations of the most prominent fecapentaene analogues as compared to omnivores. These results suggest that increased fecapentaene excretion levels result in diminished exposure of the colon epithelium, thereby indicating protective effects of high excretion rates rather than a risk factor for colorectal cancer. This appears to be in agreement with the relatively low total fecapentaene levels found in feces from patients with colorectal cancer as compared to controls (12). In this study, the initial hypothesis that colorectal cancer patients are excreting higher concentrations of fecapentaenes, had to be rejected as well.

In a second study relating fecapentaene excretion to risk for colorectal cancer, feces from patients with adenomatous polyps and matched controls were analysed for fecapentaene content. This population was selected since in most cases, colorectal carcinoma is found to arise from preexisting adenomas (45). During the early stages of colorectal carcinogenesis, mutations of proto-oncogenes and tumor suppressor genes have been found to accumulate, resulting in tumor growth with 
increasing size and invasiveness (46-48). Involvement of fecapentaenes as initiators in the transformation of colonic epithelial cells may therefore occur during relatively early stages of the carcinogenic process. It has been hypothesized that measurement of fecapentaene excretion in patients diagnosed with benign neoplasia, is of greater relevance as compared to measurement in patients in later stadia of carcinogenesis. However, the results of this study, presented in Chapter 5, indicate that no pronounced differences were found between cases and controls in fecal concentrations or total excretion per day of separate fecapentaene analogues or of total fecapentaenes. Therefore, no evidence is provided to incriminate fecapentaenes as initiators of tumorigenesis. Based on these results and the observations in the previous case-control study by Schiffman et al. (12) it is suggested that if fecapentaenes form a relevant factor in colorectal carcinogenesis, their role is more likely to be related to the transformation of late adenomas into malignant tumors.

Although intra-individual variation in excreted fecapentaene concentrations is known to be considerable, averaged fecapentaene excretion patterns and FP12/FP-14 ratios appear relatively constant over longer periods (49; de Kok unpublished results). Further, major inter-individual variation in fecapentaene concentrations has been found in feces from donors consuming identically composed diets (50). This suggests that apart from obvious effects of the diet on fecapentaene excretion, which will be extensively discussed below, other more individually determined factors are of influence on fecapentaene excretion. In this context, the production of fecapentaene-precursors, from the class of plasmalopentaenes, may be of relevance $(51,52)$. Since plasmalopentaenes are constituents of biological membranes (53), fecapentaene synthesis could be depending on the release or production of these compounds by human metabolism. This hypothesis is supported by the finding that plasmalopentaenes were detected in feces from neonatal germ-free pigs on plasmalopentaene-free diets (54). This indicates that fecapentaene-precursors may originate from hostmetabolism rather than directly from the diet or from bacterial activity. Unfortunately, dietary intake has not been evaluated in the case-control study by Schiffman et al. (12), which would have enabled discrimination between effects attributable to differences in nutrient intake and variation in fecapentaene levels possibly resulting from differences in the metabolic constitution of cases and controls.

\section{Fecapentaene excretion in relation to nutrient intake}

It has been indicated repeatedly that dietary factors are relevant determinants for colorectal cancer risk as well as the excretion of fecal mutagenicity. Therefore, in both studies on fecapentaene excretion in populations at different risk for colorectal cancer, intake of nutrients has been evaluated and related to fecal concentrations of individual fecapentaene analogues. The results of the study on fecapentaene excretion in vegetarians and omnivores as described in Chapter 3 , indicate that intake of calcium and dietary fiber are the most significant factors correlating positively to excreted fecapentaene concentrations. Intake of monounsaturated fat as well as vitamin $\mathrm{C}$ and retinol were found to correlate negatively to fecapentaene concentrations, although for the last two variables, only marginal statistical reliability was attained. No prominent differences were observed in correlations between dietary variables and FP-12, FP-14 or other fecapentaene 
Table I: Summary of relations between dietary variables and fecapentaene excretion levels.

\begin{tabular}{|c|c|c|c|c|}
\hline Reference & Population & Dietary variable & $\begin{array}{l}\text { Positively } \\
\text { correlating }\end{array}$ & $\begin{array}{l}\text { Negatively } \\
\text { correlating }\end{array}$ \\
\hline Chapter 3 & $\begin{array}{c}\text { Vegetarians and } \\
\text { omnivores }\end{array}$ & $\begin{array}{l}\text { calcium } \\
\text { fiber } \\
\text { M. U. F.* }\end{array}$ & $\begin{array}{l}\text { total FP; FP(19.5) } \\
\text { FP(17.7); FP(18.2) }\end{array}$ & $\begin{array}{l}\text { total FP; FP(13.5); } \\
\text { FP(14.0); FP(18.2) }\end{array}$ \\
\hline Chapter 5 & $\begin{array}{l}\text { Cases }^{\circ} \text { and } \\
\text { controls }\end{array}$ & $\begin{array}{l}\text { Saturated fat } \\
\text { M.U.F } \\
\text { P.U.F. } \\
\text { Linoleic acid } \\
\text { p/s ratio }\end{array}$ & $\begin{array}{l}\text { FP/day } \\
\text { FP/day } \\
\text { FP/day }\end{array}$ & $\begin{array}{l}\text { FP- } 14 \\
\text { FP- } 14\end{array}$ \\
\hline & idem, men & $\begin{array}{l}\text { M.U.F. } \\
\text { p/s ratio }\end{array}$ & $\begin{array}{l}\text { total FP; FP/day; } \\
\text { FP-12; FP-14 }\end{array}$ & FP-14 \\
\hline & idem, women & Mono-+ di-sacch. & & FP- 14 \\
\hline $\begin{array}{r}\text { Schiffman } \\
(32)\end{array}$ & $\begin{array}{l}\text { Cases }^{\circ} \text { and } \\
\text { controls } \\
\text { Cases }\end{array}$ & $\begin{array}{l}\text { Citrus fruits } \\
\text { Butter and margarine } \\
\text { Suppl. vit. C and E } \\
\text { Variety of fruits } \\
\text { Butter and margarine } \\
\text { Suppl. vit.C, B, } \\
\quad \text { A, and D } \\
\text { Thiobromine } \\
\text { (Citrus) fruits } \\
\text { Fiber } \\
\text { Yellow and green } \\
\quad \text { vegetables } \\
\text { Vitamin C } \\
\text { Suppl. vit. C and E } \\
\text { Molybdenum }\end{array}$ & & $\begin{array}{l}\text { total FP } \\
\text { total FP } \\
\text { total FP } \\
\text { total FP } \\
\text { total FP } \\
\text { total FP } \\
\text { total FP } \\
\text { total FP } \\
\text { total FP } \\
\text { total FP } \\
\text { total FP } \\
\text { total FP } \\
\text { total FP }\end{array}$ \\
\hline
\end{tabular}

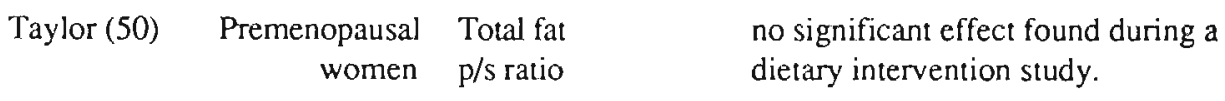

Jacob (55) Healthy men Vitamin C

FP-12,

(depletion study)

FP-12-precursor**

All correlations have been evaluated in non-parametric signed rank tests $(p<0.05)$. M.U.F.: monounsaturated fat; P.U.F.: poly-unsaturated fat; Suppl. vit. C: supplemental vitamin C; sacch.: saccharides. ${ }^{*}$ in stepwise regression analysis; ${ }^{\circ}$ cases with benign gastrointestinal disorders; ${ }^{* *}$ determined after anaerobic incubation of fecal samples. 
analogues. Dietary intake was also evaluated in the case-control comparison of fecapentaene excretion described in Chapter 5. In contrast to the results from the first study, dietary calcium and fiber were not found to correlate strongly to fecapentaene concentrations. This may be a consequence of the fact that variation in the intake of dairy products, vegetables, fruit and cereal products which account largely for the intake of calcium and fiber, is less pronounced within this general population as compared to a population divergently consisting of omnivores as well as vegetarians. On the other hand, p/s ratio, poly-unsaturated fat and linoleic acid were found to correlate positively to total fecapentaene excretion per day. Consumption of saturated and mono-unsaturated fat were found to correlate negatively to fecal concentrations of total FP-14. Additionally subdivision into male and female subpopulations showed that $\mathrm{p} / \mathrm{s}$ ratio is correlating to FP-12, FP-14 and total fecapentaene concentrations as well as excretion per day in men. Combined intake of mono- and di-saccharides appeared to be the only significantly correlating factor in female FP-14 excretion. A summary of these results and correlations found in previous research by other investigators in shown in Table $\mathrm{I}$. The most remarkable inconsistency in these results is the fact that in the case-control study (Chapter 5), p/s ratio and the consumption of mono- and poly-unsaturated fat appear relevant factors in fecapentaene excretion, whereas no effects of $\mathrm{p} / \mathrm{s}$ ratio or total amount of fat has been found in a dietary intervention study in premenopausal women (50). On the other hand, consumption of margarine and butter, of which the latter is known to contain high amounts of saturated fat, was found to correlate negatively with total fecapentaene excretion (32), and thus appears to be in agreement with the positive correlations found between $\mathrm{p} / \mathrm{s}$ ratio and fecapentaene excretion in our casecontrol study. Further, a significant positive correlation is found between consumption of fiber and both analogues of FP-14 as well as total fecapentaenes in the study on omnivores and vegetarians, whereas Schiffman et al. report an inverse association between fiber and concentration of total fecapentaenes (32). This difference may be caused by the application of two different extraction procedures, of which our method enables a relatively high recovery of the fiberbound fecapentaene fraction (see Chapter 4). Relatively low recovery of the fiberbound fecapentaene fraction on the other hand will result in negative correlations between fiber consumption and fecapentaene concentrations.

Based on these results and the fact that significant differences were found in fecapentaene excretion between vegetarians and omnivores, it is concluded that diet is an important determinant of fecapentaene excretion. Although results from various studies appear not always consistent, intake of fiber, calcium, vitamin C and $\mathrm{E}$ as well as consumption of saturated, mono- and poly- unsaturated fat, and thereby also $\mathrm{p} / \mathrm{s}$ ratio, are indicated as relevant dietary factors in fecapentaene excretion.

\section{Kinetic aspects of fecapentaene excretion}

Fecapentaene concentrations quantified in feces, represent the integrated endresult of fecapentaene synthesis, chemical decomposition, resorption and other kinetic aspects of fecapentaene excretion. Determination of relationships between nutrients and fecapentaene concentrations may thus be hampered since diet influences fecapentaene excretion by several distinct mechanisms. Therefore, in 
Chapter 4 an in vitro model has been described to study possible interactions of fiber, bile acids and calcium on fecapentaene excretion kinetics in the bowel. In this in vitro system, fiber material was hydrated with PBS and after addition of synthetic FP-12 fecapentaene binding capacity was calculated, expressed as a distribution ratio representing the part of totally recovered FP-12 present in aqueous solution:

[FP-12] $\mathrm{PBS}$

Distribution ratio $=$

$$
[\text { FP-12] PBS }+[\text { FP-12] fiber }
$$

As previously indicated in this chapter, a strong fecapentaene binding capacity was found using B-cellulose, wheat- and oat-bran. From studies on modulating effects of bile acids and calcium on the distribution ratio, it was concluded that bile acids are capable of increasing the fecapentaene fraction in solution. This effect was shown to be reduced by precipitation of bile acids with calcium. It was hypothesized that as a consequence of the strong adsorption of fecapentaenes to fiber, excretion may be induced by high fiber diets, ultimately resulting in reduced exposure levels of the colorectal epithelial cells. In contrast, fecal bile acids, which are generally related to increased risk for colorectal cancer (56-60), are suggested to increase the bioavailability of fecapentaenes for intestinal resorption by the observed solubilizing effect. As a result, high fat diets which are known to stimulate bile acid production, may result in enhancement of cellular fecapentaene resorption and thus in diminished fecal concentrations. The strong correlation between dietary calcium and fecapentaene excretion found in Chapter 3, may be explained by the reduction of fecapentaene-solubilization by fecal bile acids after precipitation with calcium.

These results demonstrate that studying interactions between dietary factors and fecapentaenes may contribute to a better understanding of the processes involved in the excretion of these mutagens. On the other hand, it is well known that for instance fiber may affect fecapentaene concentrations by several other ways than by binding fecapentaenes alone. First, high fiber consumption may results in a decreased fecapentaene concentrations due to increased fecal bulk. Further, high fecal fiber contents are known to decrease bowel passage time and thereby limiting periods for microbial fecapentaene synthesis. This effect thus results in lower fecapentaene concentrations. Finally, decreased passage times also limits the possibility for intestinal resorption, leading to increased fecapentaene concentrations. Therefore, it should be emphasized that in order to reliably assess possible risk for colon cancer related to fecapentaene excretion, all relevant interactions between fecal constituents and their influence on fecapentaene synthesis, resorption, stability and excretion have to be thoroughly understood.

Taken all together, it might be argued that in view of the complexity of possible interactions occurring in a fecal matrix, reliable assessment of in situ cellular fecapentaene exposure by measuring fecal excretion will ever be possible. An alternative for monitoring fecapentaene excretion as marker for possible colorectal cancer risk may be provided by the analysis of specific fecapentaene-induced genetic damage, which will be discussed below. It should be noted that such 
analyses will not be applicable for examination in large populations, and will be limited by the availability of bowel resection specimens.

\subsection{Mechanism of fecapentaene genotoxicity}

The genotoxic potential of the fecapentaenes has been reviewed in Chapter 1.3. The most important characteristics of fecapentaene genotoxicity can be summarized as follows:

1. FP-12 has been found to be a potent mutagen to S. typhimurium, E. coli, mouse BALB/c 3T3 cells, rat hepatocytes and human lymphocytes and fibroblasts $(1-10)$.

2. Mutagenicity to Salmonella was found to depend on the presence of the 5 double bonds in combination with the enol ether oxygen $(4,6)$.

3. The mutagenic response of Salmonella strains TA 100 and TA 98 have been found to differ under aerobic and anaerobic conditions, suggesting a dual mechanism of action (5).

4. Assessment of the relative genotoxicity revealed that FP-12 at a molar basis is equally or even more mutagenic as compared to reference mutagens like 4nitroquinoline, $\mathrm{N}$-methyl- $\mathrm{N}$-nitrosurea and formaldehyde $(7,10)$.

5. The mechanism of action may involve induction of oxidative DNA damage, indirectly caused by the formation of reactive oxygen species during fecapentaene decomposition, or direct induction of DNA alkylation by fecapentaenes or fecapentaene-derived aldehydes (10,18,61-67).

The main objectives of the experiments described in Chapter 6 and 7 of this thesis, are to establish oxygen radical formation during aerobic decomposition of FP-12 and to study the involvement of these radicals in the induction of oxidative damage to DNA as well as the accompanying biological consequences. Further, some preliminary results on specific fecapentaene-DNA adduct formation have been presented and the relative importance of oxidative and alkylating DNA modifications in fecapentaene genotoxicity is discussed.

\section{Oxygen radical formation by FP-I2 and induction of oxidative and alkylating DNA damage}

As described in Chapter 6, electron spin resonance spectroscopy (ESR) was applied to investigate the formation of reactive oxygen species by FP-12. Using 5,5-dimethyl-1-pyrroline $\mathrm{N}$-oxide (DMPO), $\alpha$-(4-pyridyl-1-oxide)- $\mathrm{N}$-t-butylnitrone (POBN) and 2,2,6,6-tetramethylpiperidine (TMP) as spin trapping agents, this techniques appeared not capable of detecting spontaneous radical formation by FP-12. In contrast, enzymatic peroxidation of FP-12 under aerobic conditions by three different peroxidases was found to result in the generation of superoxide and OH-radicals. The identity of these radicals was established by comparison of ESR-splitting constants of spintrap adducts formed during exposure to FP-12 with reference spectra. Furthermore, analysis of 2'-deoxy-7,8-dihydro-8-oxoguanosine (8-oxodG) after incubation of isolated deoxyguanosine (dG) with FP-12 showed a dose-dependent induction of this marker for oxidative DNA damage. Enzymatic peroxidation of FP-12 appeared not essential for the induction of 8-oxodG, 
although it was found to increase the hydroxylation ratio considerably. Therefore, it has to be concluded that reactive oxygen species are generated by FP-12 spontaneously, whereas radical formation levels apparently are below detection limits in our ESR studies. This conclusion is furthermore supported by the first observations of oxidative DNA damage spontaneously induced by FP-12 and FP14 in isolated calf thymus DNA (66), as well as recent reports on combined oxy/alkyl ESR spectra (65).

Apart from ESR spectral characterization, the identity of oxygen radicals involved in the induction by FP-12 of 8-oxodG and ESR-signals was studied by application of radical scavengers and superoxide dismutase (SOD). The formation of superoxide as determined by ESR experiments was confirmed by the observation of reduced hydroxylation ratios after addition of DMPO. In contrast to the reducing effect on ESR-spectral intensities, administration of t-butylalcohol (tBA) as OH-radical scavenger appeared of little influence on FP-12 induced hydroxylation of $\mathrm{dG}$. Involvement of singlet oxygen was indicated by effects on 8-oxodG induction of sodium azide or $\mathrm{D}_{2} \mathrm{O}$ which are known to respectively quench or stabilize singlet oxygen (68). These contradictory effects observed in ESR and 8-oxodG measurements may be explained by the fact that the formation of 8-oxodG is a relatively minor lesion in the oxidative DNA-damage spectrum of OH-radicals as compared to the DNA-damage spectrum of singlet oxygen (69-71). Formation of singlet oxygen could not be identified on ESR spectral analysis, since TMP, used to trap singlet oxygen, appeared to be not specific (72). Therefore, the combined results of ESR measurements and analysis of 8-oxodG indicate that superoxide as well as OH-radicals and singlet oxygen may be involved in the induction of oxidative DNA damage and thereby in fecapentaene genotoxicity.

Apart from 8-oxodG induction in $\mathrm{dG}, \mathrm{FP}-12$ was also found to induce oxidative damage to ss and ds rat liver DNA. Enzymatic peroxidation of FP-12 was found to result in elevated 8-oxodG levels in ss DNA, but not in ds DNA, probably due to the relative inaccessibility of guanine residues in ds DNA for free radicals as compared to $\mathrm{dG}$ and ss DNA.

The second mechanism of fecapentaene genotoxicity based on the induction of DNA alkylation was studied in ${ }^{32} \mathrm{P}$ postlabelling experiments. Preliminary results demonstrated 5 additional spots of putative fecapentaene-DNA adducts after exposure of ss DNA to FP-12. The formation of these additional spots was not found in analyses of reference DNA, and appeared to be almost completely inhibited by addition of prostaglandin $\mathrm{H}$ synthase (PHS) as peroxidative enzyme to the incubation mixtures. Although further characterization is essential to identify these adducted nucleotides, these data confirm the possible formation of several fecapentaene-derived alkyl adducts as have recently been reported (65). These results further indicate that enzymatic peroxidation of FP- 12 by addition of PHS, inhibits adduct formation, possibly by peroxidation of DNA-interactive aldehydes generated during spontaneous FP-12 decomposition.

An overview on the results from the studies performed on free radical generation, induction of oxidative and alkylating DNA damage by FP-12 is presented in Scheme 1. In summary, it was demonstrated that during aerobic decomposition of 


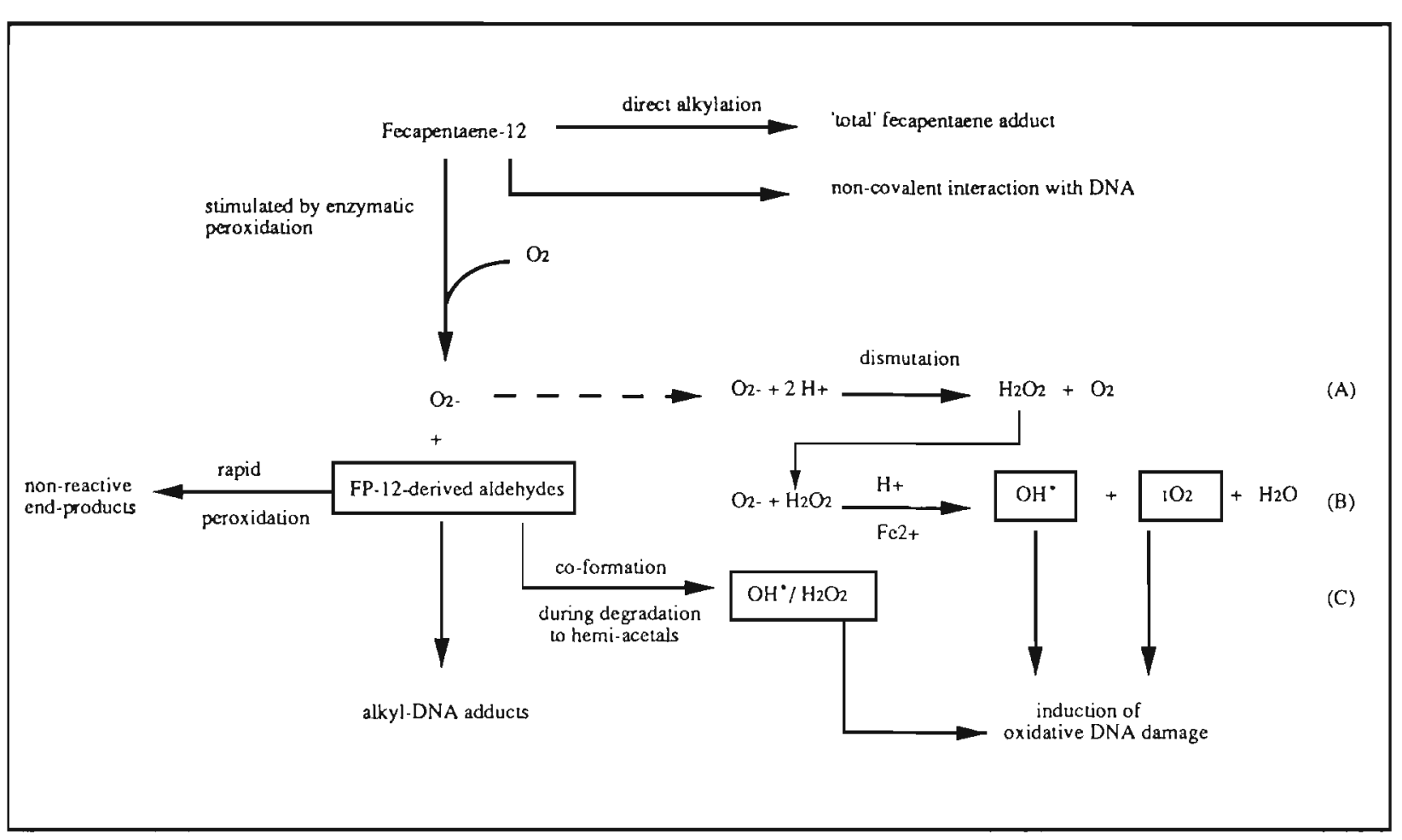

Scheme 1: Overview of the suggested pathways of FP-12 decomposition, resulting in the formation of free radicals, which in turn may induce oxidative and alkylating-DNA damage. See text for further explanation. 
FP-12 which may be enhanced by enzymatic peroxidation, superoxide anions, $\mathrm{OH}$-radicals and singlet oxygen are generated. These reactive oxygen species may induce oxidative damage to dG, ss and ds DNA which appears to depend on the accessibility of the guanine residue. Further, it was indicated that oxidative and alkylating DNA damage can be induced in ss DNA simultaneously by spontaneous fecapentaene decomposition. Since peroxidation of FP-12 was found to inhibit putative fecapentaene-adduct formation, it is hypothesized that alkylating decomposition products are rapidly peroxidized to inactive end-products. Since FP-12 has been found mutagenic to Salmonella TA 98 at anaerobic conditions (5), 'total' fecapentaene-adducts or non-covalent interactions with DNA may be induced which are independent of the oxygen status.

The mechanism postulated to explain the formation of $\mathrm{OH}$-radicals and singlet oxygen, involves the generation of superoxide from FP-12 at aerobic conditions. Addition of SOD was found to reduce ESR spectral intensities of the superoxide adducts of both DMPO and POBN, but resulted in the increased TEMPO signal formed by trapping of both OH-radicals and singlet oxygen by TMP. This indicates that $\mathrm{OH}$-radicals and/or singlet oxygen are likely to originate from dismutation of superoxide in combination with the iron catalyzed Haber-Weiss reaction (Scheme 1, eqn. A and B). This reaction sequence is further supported by the absence of OH-radical adducts of DMPO and POBN in presence of the iron chelator DTPA, which is found to block the Haber-Weiss route. An alternative mechanism for free radical formation has been postulated by Vertegaal et al. (67). This involves a 1 -electron transfer from FP-12 to oxygen, resulting in a radical cation and superoxide anion, which are suggested to combine and form a peroxide zwitterion. Enol ethers like FP-12, may further degrade to hemi-acetals by a process that liberates hydroxyl radicals and/or hydrogen peroxide. An hydroxysubstituted aldehyde is the end-product of this reaction pathway. However, this mechanism does not explain the formation of singlet oxygen and is not in accordance with the observed stimulation of $\mathrm{OH}$-radical / singlet oxygen generation after enzymatic dismutation of superoxide. On the other hand, it may be suggested that both reaction pathways occur simultaneously.

\section{Fecapentaene genotoxicity and measurement of biological effects}

The biological consequences of DNA damage induced by FP-12 have been studied in the Salmonella mutagenicity assay using strains TA 100, 102 and 104 (Chapter 6) and in the $\phi \mathrm{X}-174$ DNA inactivation assay (Chapter 7). Mutagenicity of FP-12 to Salmonella was found to be reduced by addition of both spintraps DMPO and TMP, as well as the OH-radical scavenging agents tBA and DMSO. The effect of both DMPO and TMP were found to be more pronounced as compared to the other radical scavengers. This may be explained by the fact that DMPO is known to react with both OH-radicals and superoxide, whereas TMP was found to trap both OH-radicals and singlet oxygen. Since it has been suggested that superoxide is not likely to induce biologically relevant DNA damage, the inhibitory effect of DMPO may be attributable to the reduced formation of both OH-radicals and singlet oxygen. Alternatively, it may be suggested that scavenging superoxide by DMPO furthermore results in blocking the formation of reactive aldehydes by the reaction mechanism proposed by 


\section{Chapter 8}

Vertegaal et al. (67), inhibiting induction of both oxidative and alkylating DNA damage.

Further, OH-radical scavenging was shown to reduce cytotoxic effects of FP-12 as well. These results indicate that superoxide, $\mathrm{OH}$-radicals and/or singlet oxygen are important factors in mutagenic and cytotoxic effects of fecapentaenes to Salmonella. No discrimination between effects of $\mathrm{OH}$-radicals and singlet oxygen could be established in these experiments since sodium azide, a singlet oxygen quenching agent is mutagenic to Salmonella, and no other specific scavengers of singlet oxygen are available.

In contrast to the Salmonella mutagenicity assay, the $\phi \mathrm{X}-174$ DNA inactivation test as described in Chapter 7, provides a model in which biological consequences of interactions between xenobiotics and DNA can be studied without interference by cellular components. Inactivation of bacteriophage DNA has been reported to be a sensitive biological marker for the induction of oxidative DNA damage $(73,74)$. Furthermore, inactivation of $\phi \mathrm{X}-174 \mathrm{DNA}$ by alkylating toxicants has also been reported $(75,76)$. FP-12 was found to reduce $\phi X-174$ DNA surviving rates within 24 hours by nearly 4 decades. In contrast to the significant reduction of mutagenicity to Salmonella, only a minor inhibition of $\phi X-174$ DNA inactivation by FP- 12 was found as a result of radical scavenging by DMPO or tBA, with or without enzymatic peroxidation. This suggests that induction of oxidative DNA damage only contributes to a relatively minor extent to the phage DNA inactivation. This appears in accordance with the observation that after enzymatic peroxidation of FP-12, DNA inactivation is found to be reduced, whereas generation of free radicals and hydroxylation of ss DNA was found to be increased under comparable incubation conditions. As a consequence, the reduced inactivation of $\phi X-174$ DNA after enzymatic peroxidation of FP-12 may be attributable to the rapid disappearance of reactive FP-12 derived intermediates, which was also suggested to explain the inhibition of adducted nucleotides observed in ${ }^{32} \mathrm{P}$ postlabelling analyses of ss DNA.

According to the mechanism of aerobic FP-12 decomposition based on the reaction between superoxide and the FP-12 radical cation (67), addition of DMPO will result in inhibition of aldehyde generation. This implicates that inactivation of $\phi \mathrm{X}-174$ DNA has to be attributed to 'total' FP- 12 adduct formation or non-covalent DNA interactions with FP-12. In future research, this hypothesis could be examined by studying fecapentaene-adduct formation in combination with DMPO and SOD.

Finally, it should be noted that analysis of 8-oxodG levels in DNA from human fibroblasts exposed to $60 \mu \mathrm{M}$ FP-12, did not reveal significantly increased hydroxylation levels. However, genotoxic effects like mutations, sister chromatid exchanges and single strand breaks have been reported after exposure of fibroblast to FP-12 concentrations ranging for 0.4 to $20 \mu \mathrm{M}$ (7). This indicates that FP-12 induced genotoxic effects may not result from oxidative damage but may relate to other forms of DNA modification such as direct alkylation. 32P postlabelling analysis of DNA from human fibroblasts after exposure to $40 \mu \mathrm{M}$ has recently demonstrated formation of one putative fecapentaene DNA adduct, further supporting this hypothesis (65). 
In summary, it has been demonstrated that oxygen radicals generated by FP-12 induce mutagenic effects to Salmonella, which can be partially inhibited by radical scavenging. In contrast, inhibition of FP-12 induced inactivation of ss $\phi X$ 174 DNA by radical scavenging was shown to be limited. Further, no oxidative DNA damage was found in FP-12 exposed fibroblasts at incubation conditions which have been reported to result in genotoxic effects. Based on these findings it can be concluded that induction of oxidative DNA damage by oxygen radicals generated during fecapentaene decomposition plays only a minor role in fecapentaene-genotoxicity. This may emphasize the importance of further studies on the structure elucidation of putative fecapentaene-adducts and chemical synthesis of proper standards. Since it was concluded in Chapter 8.2 that assessment of cellular exposure levels in the human colon based on quantitative analysis of fecapentaene excretion has its limitations, ${ }^{32} \mathrm{P}$ postlabelling of specific fecapentaene adducts may provide a new starting point for studies to establish the role (if any) of fecapentaenes in colorectal carcinogenesis. Although in vitro studies on fecapentaene genotoxicity demonstrated that induction of 8-oxodG is of minor importance, both types of DNA damage should be evaluated in in vivo experimental studies and related to possible carcinogenic events. This seems indicated, since free radicals may also cause epigenetic effects, for instance by stimulating cell proliferation as a consequence of cytotoxic effects or by interfering with DNA repair processes.

\subsection{General conclusions}

In this thesis, the role of fecapentaenes in colorectal carcinogenesis as well as the mechanism of fecapentaene genotoxicity have been studied. It has been demonstrated that relatively high concentrations of fecapentaenes are excreted by a vegetarian population at relatively low risk for developing colorectal cancer, as compared to 'high risk' omnivores. Apart from the fact that diet apparently is an important factor in fecapentaene excretion, this demonstrates that high fecapentaene excretion levels relate to colon cancer risk protection. A possible mechanism for the explanation of this relation between fecapentaene excretion and reduction of colon cancer risk has been proposed, involving modulating effects of dietary factors on fecapentaene kinetics in the bowel. Results from a second study relating fecapentaenes to risk for colorectal cancer, showed no differences in fecapentaene excretion levels between healthy controls and patients with adenomatous polyps, a benign stadium of colon-tumorigenesis. Based on these observations, it is concluded that fecapentaenes are not likely to be involved in the induction of colorectal carcinogenesis. However, it can not be excluded that fecapentaenes are involved during later phases in the development of this disease. This hypothesis is supported by the observation that patients with completely developed colon carcinomas excrete significantly lower levels of fecapentaenes as compared to controls (12). Since fecapentaenes may not be complete carcinogens, potential promoting or progressional activities should be established in future research. On the other hand, there is circumstantial evidence that genetic damage can be induced by FP-12. Studies on the mechanism of fecapentaene genotoxicity 
have demonstrated that during aerobic decay of FP-12 oxygen radicals as well as DNA-alkylating compounds are generated simultaneously, which are found to induce both oxidative and alkylating DNA damage. It has been suggested that the induction of oxidative DNA damage by FP-12 is of relatively minor importance in the causation of biologically relevant effects. Further, it is concluded that for the induction of genetic damage by FP-12, the accessibility of the target sites is of major importance.

Although the results presented in this thesis contribute to the basic understanding of fecapentaene genotoxicity, risk assessment of fecapentaene exposure is still hampered by the inconsistency between the high in vitro genotoxic potential of FP-12 and results from epidemiological as well as the majority of carcinogenicity studies. Nevertheless, because fecapentaenes have been found to induce histochemical changes in human colon explants as well as a broad spectrum of genetic damage both in vitro and in colorectal epithelial cells after rectal administration in rodent carcinogenicity studies $(9,18,19)$, it is indicated that fecapentaenes should be considered as hazardous compounds. Therefore, additional studies focussing on crucial genetic endpoints in appropriate animal carcinogenicity models and in human colonic epithelium seem essential in order to establish the relevance of the fecapentaenes in the process of colorectal carcinogenesis.

\section{References}

1. Govindan, S.V., Kingson, D.G.I., Gunatilaka, A.A.L., van Tassell, R.L., Wilkins, T.D., de Wit, P.P., van der Steeg, M and van der Gen, A. (1987), Synthesis and biological activity of analogs of fecapentaene-12. J. Nat. Prod., 50, 75-83.

2. Göggelmann, W., Maier, F.K. and Pfaendler, H.R. (1986) Mutagenicity of synthetic racemic fecapentaene-12. Mutat. Res. 174, 165-167.

3. Curren, R.D., Putman, D.L., Yang, L.L., Hayworh, S.R., Lawlor, T.E., Plummer, S.M. and Harris, C.C. (1987) Genotoxicity of fecapentaene-12 in bacterial and marnmalian cell assay systems. Carcinogenesis, 8. 349-352.

4. Peters, J.H., Riccio, E.S., Stewart, K.R. and Reist E.J. (1988) Mutagenic activities of fecapentaene derivatives in the Ames/Salmonella test system. Cancer Lett. 39, 287296.

5. Venitt, S. and D. Bosworth (1988) The bacterial mutagenicity of synthetic all-trans fecapentaene-12 changes when assayed under anaerobic conditions. Mutagenesis $\mathbf{3}$, 169-173.

6. Voogd, C.E., Vertegaal, L.B.J., van der Steeg, M., van der Gen, A. and Mohn, G.R. (1990) Structure, chemical reactivity and in vitro mutagenic activity in a series of fecapentaene analogues. Mutation Res., 243, 195-199.

7. Plummer, S.M., Grafstrom, R.C., Yang L.L., Curren, R.D., Linnainmaa, K. and Harris, C.C. (1986) Fecapentaene-12 causes DNA damage and mutations in human cells. Carcinogenesis, 7, 1606-1609.

8. Schmid, E., Bauchinger, M., Braselmann, H., Pfaendler, H.R. and Göggelmann, W. (1987): Dose-response relationship for chromosome aberrations induced by fecapentaene-12 in human lymphocytes. Mutat. Res., 191, 5-7.

9. Shamsuddin, A.M., Ullah, A., Baten, A. and Hale, E. (1991) Stability of fecapentaene-12 and its carcinogenicity in F-344 rats. Carcinogenesis, 12, 601-607. 
10. Nair, P.P., Shami, S., Sainz, E., Judd, J.T., Taylor, P.R. and Schatzkin, A. (1991) Quantitative assessment of the genotoxicity of fecapentaenes. Mutat. Res., 260, 153 157.

11. Schiffman, M.H., Van Tassell, R.L., Andrews, A.W., Wacholder, S., Daniel, J., Robinson, A., Smith, L., Nair, P.P. and Wilkins T.D. (1989) Fecapentaene concentration and mutagenicity in 718 North American stool samples. Mutat. Res. 222, 351-357.

12. Schiffman, M.H., Van Tassell, R.L., Robinson, A., Smith, L., Daniel, J., Hoover, R.N., Weil, R., Rosenthal, J., Nair, P.P., Schwartz, S., Pettigrew, H., Curale, S., Batist, G., Block, G. and Wilkins, T.D. (1989): Case-Control study of colorectal cancer and fecapentaene excretion. Cancer Res. 49, 1322-1326.

13. Schiffman, M.H., Bitterman, P., Viciana, A.L., Schairer, C., Russel, L., Van Tassell, R.L. and Wilkins T.D. (1988): Fecapentaenes and their precursors throughout the bowel- Results of an autopsy study. Mutat. Res. 208, 9-15.

14. Block, H.B., Dietrich, M.F., Leake, R., Laidlaw, S.A., Vinton, N.E. and Kopple, J.D. (1990): Fecapentaene excretion: aspects of excretion in newbom infants, children and adult normal subjects and in adults maintained on total parenteral nutrition. Am. $J$. Clin. Nutr. 51, 698-704.

15. Peters, J.H., Nolen, H.W., Gordon, G.R., Bradford, W.W., Bupp, J.E. and Reist, E.J. (1989): Combined chromatographic-isotopic dilution analysis of fecapentaenes in human feces. J. chromatogr. 488, 301-313.

16. Kivits, G.A.A., de Boer, B.C.J., Nugteren, C.H., van der Steeg, M., Vertegaal, L.B.J. and van der Gen, A., (1990), Quantitative HPLC analysis of the level of fecapentaenes and their precursors in human feces by a chemical conversion method. J. Nat. Prod. 53, 42-49.

17. Weisburger, J.H. Jones, R.C., Wang, C.X., Backlund, J.Y.C., Williams, G.M., Kingston, D.G.I., Van Tassell, R.L., Keyes, R.F., Wilkins, T.D., De Wit, P.P., Van der Steeg, M. and Van der Gen, A. (1990) Carcinogenicity tests of fecapentaene-12 in mice and rats. Cancer Lett. 49, 89-98.

18. Vaughan, D.J., Furrer, R., Baptista, J. and Krepinsky, J.J. (1987) The effect of fecapentaenes on nuclear aberrations in murine colonic epithelial cells. Cancer Lett., 37, 199-203.

19. Hinzman, M.J., Novotney, C., Ullah, A. and Shamsuddin, A.M. (1987) Fecal mutagen fecapentaene-12 damages mammalian colon epithelial DNA. Carcinogenesis, 8, 1475-1479.

20. Ward, J.M., Anjo, T., Ohannesian, L. Keefer, L.K., Devor, D.E., Donovan, P.J., Smith, G.T., Henneman, J.R., Streeter, A.J., Konishi, N., Rehm, S. Reist, E.J., Bradford, W.W. and Rice, J.M. (1988) Inactivity of fecapentaene-12 as a rodent carcinogen or tumor initiator. Cancer Lett. 42, 49-59.

21. Bruce, W.R., Varghese, A.J., Furrer, R. and Land, P.C. (1977) A mutagen in the feces of normal humans. In Hiatt, H.H., Watson, J.K. and Winston, J.A. (eds), Origins of human cancer. Cold Spring Harbor Laboratory Press, Cold Spring Harbor, NY, pp. $1641-1644$.

22. Wilkins, T.D., Lederman, M., Van Tassell, R.L., Kingston, D.G. and Henion, J. (1980) Characterization of mutagenic bacterial product in human feces. Am. J. Clin. Nutr. 33, 2513-2520.

23. Van Tassell, R.L., MacDonald, D.K. and Wilkins, T.D. (1982): Production of a fecal mutagen by bacteroides spp. Infection and Immunity 3, 975-980. 
24. Van Tassell, R.L., MacDonald, D.K. and Wilkins, T.D. (1982) Stimulation of mutagen production in human feces by bile and bile acids. Mutat. Res. 103, 233-239.

25. Krepinsky, J.J. (1988): Formation and biological effects of fecapentaenes. Prog. Biochem. Pharmacol. 22, 35-47.

26. Hayatsu, H., Arimoto, S. Togawa, K. and Makita, M. (1981): Inhibitory effect of the ether extract of human feces on activities of mutagens: inhibition by oleic and linoleic acids. Mutat. Res. 81, 287-293.

27. Schiffman, M.H. (1986) Epidemiology of fecal mutagenicity. Epidemiologic Rev. 8, 92-105

28. De Vet,. H.C.W., Sharma, C., and Reddy, B.S. (1981) Effect of dietary fried meat on fecal mutagenic and co-mutagenic activity in humans. Nutrition Reports International, 23, 653-660.

29 Dion, P.W., Bright-See, E.B., Smith, C.C. and Bruce, W.R. (1982) The effect of dietary ascorbic acid and tocopherol on fecal mutagenicity. Mutat. Res. 102, 27-37.

30. Reddy, B.S., Sharma, C., Mathews, L. and Engle, A. (1984): Fecal mutagens from subjects consuming a mixed-westem diet. Mutat. Res. 135, 11-19.

31. Reddy, B.S., Engle, A, Katsifis, S., Simi, B., Bartram, H., Perrino, P. and Mahan, C. (1989) Biochemical epidemiology of colon cancer: Effect of types of dietary fiber on fecal mutagens, acid and neutral sterols in healthy subjects. Cancer Res. 49, 46294635 .

32. Schiffman, M.H. (1987): Diet and faecal genotoxicity. Cancer Surveys 6, 653-672.

33. Drasar, B.S. and Irving, D. (1973) Environmental factors and cancer of the colon and breast. Br. J. Cancer, 27, 167-172.

34. Armstong, B. and Doll, R. (1975) Environmental factors and the incidence and mortality from cancer in different countries with special reference to dietary practice. Int. J. Cancer, 15, 617-631.

35. Carroll, K. and Khor, H.T. (1975) Dietary fat in relation to tumorigenesis. Prog. Biochem. Pharmacol., 10, 308-353.

36. Correa, P. (1981) Epidemiological correlations between diet and cancer frequency. Cancer Res., 41, 3685-3690.

37. Liu, K., Moss, M., Persky, V.Stamler, J., Garside, D. and Soltero, I. (1979) Dietary cholesterol, fat and fiber and colon cancer mortality, an analysis of international data. Lancet ii, 782-785.

38. Hill, M.J., Maclennen, R. and Newcombe, J. (1979) Diet and large bowel cancer in three socio-economic groups in Hong Kong. Lancet $\mathrm{i}, 436$.

39. McKeown-Eyssen, G.E.M., and Bright-See, E. (1984) Dietary factors in colon cancer: intemational relationships. Nutr. Cancer, 6, 160-170.

40. Yeung, K.S., McKeown-Eyssen, G.E., Li, G.F., Glazer, E., Hay, K., Child, P., Gurgin, V., Zhu, S.L., Baptista, J., Aloe, M., Mee, D., Jazmaji, V., Austin, D.F., Li, C.C. and Bruce, W.R. (1991) Comparisons of diet and biochemical characteristics of stool and urine between chinese populations with low and high colorectal cancer rates. J. Natl. Cancer Inst., 83, 46-50.

41. Tuyns, A.J., Kaaks, R. and Haelterman, M. (1988) Colorectal cancer and the consumption of foods: A case-control study in Belgium. Nutr. Cancer, 11, 189-204.

42. Kuhnlein, U., Bergstrom, D.and Kuhnlein, H. (1981) Mutagens in feces from vegetarians and non-vegetarians. Mutat. Res. 85, 1-12.

43. Kuhnlein, H.V., Kuhnlein, U. and Bell P.A. (1983) The effect of short-term dietary modification on human fecal mutagenic activity. Mutat. Res. 113, 1-12.

44. Mower, H.F., Ichinotsubo, D., Wang, L.W., Mandel, M., Stemmermann, G., 
Nomura, A., Heilbrun, L., Kamiyama, S. and Shinada A. (1982) Fecal mutagens in two japanese populations with different colon cancer risks. Cancer Res, 42, 1164 1169.

45. Sugarbaker, P.H., Gunderson, L.L. and Wittes, R.E., (1985) Colorectal cancer. In: DeVita, V.T., Hellman, S and Rosenberg, S.A. (eds) Cancer, principles and practice of oncology, 1, 2nd edition, J.B. Lippincott company, Philadelphia, pp 795885 .

46. Vogelstein, B., Fearon, E.R., Baker, S.J., Nigro, J.M., Kern, S.E., Hamilton, S.R., Bos, J., Leppert, M., Nakamura, Y. and White, R. (1989) Genetic alterations accumulate during colorectal tumorigenesis. In: Cavenee, W., Hastie, N. and Stanbridge, E. (eds) Recessive oncogenes and tumor suppression, Cold Spring Harbor, New York.

47. Vogelstein, B., Fearon, E.R., Hamilton, S.R., Kern, S.E., Preisinger, A.C., Leppert, B.A., Nakamura, Y., White, R., Smits, A.M.M., and Bos, J.L. (1988) Genetic alterations during colorectal-tumor development. New Engl. J. Med., 319, 525-532.

48. Fearon, E.R. and Vogelstein, B. (1990) A genetic model for colorectal tumorigenesis. Cell, 61, 759-767.

49. Wilkins, T.D., and Van Tassell R.L. (1983) Production of intestinal mutagens. In: Hentges, D.J. ed. Human intestinal microflora in health and disease, Academic press New York, pp 265-288.

50. Taylor, P.R., Schiffman, M.H., Jones, D.Y., Judd, J., Schatzikn,A., Nair, P.P., Van Tassell, R.L. and Block, G. (1988): Relation of changes in amount and type of dietary fat to fecapentaenes in premenopausal women. Mutat. Res. 206, 3-9.

51. Van Tassell, R.L., Piccariello, T., Kingston, D.G., Wilkins, T.D. (1989) The precursors of fecapentaenes: Purification and properties of a novel plasmalogen. Lipids 24, 454-459.

52. Kingston, D.G.I., Piccariello, D.T., Keyes, R.F., Van Tassell, R.L. and Wilkins, T.D. (1989) Isolation and structure elucidation of plasmalopentaene-12 the biological precursor of fecapentaene-12. Tetrahedron Lett. 30, 6665-6668.

53. Mangold, H.K. and Weber, N. (1987) Biosynthesis and biotransformation of ether lipids. Lipids, 22, 789-799.

54. Kingston, D.G.I., Van Tassell, R.L. and Wilkins, T.D. (1990) The fecapentaenes, potent mutagnes from human feces. Chem. Res. Toxicol, 3, 391-400.

55. Jacob, A., Keley, D.S., Pianalto, F.S., Swendseid, M.E., Henning, S.M., Zhang, J.Z., Ames, B.N., Fraga, C.G. and Peters, J.H. (1991) Immunocompetence and oxidant defense during ascorbate depletion of healthy men. Am. J. Clin. Nutr, 54, 1302S-1309S.

56. Owen, R.W., Dodo, M., Thompson, M.H. and Hill, M.J. (1987) Fecal steroids and colorectal cancer. Nutrition and Cancer, 9, 73-80.

57. McKeigue, P.M., Adelstein, A.M., Marmot, M.G., Henly, P.J., Owen, R.W., Hill, M.J. and Thompson, M.H. (1989) Diet and fecal steroid profile in a South Asian population with a low colon-cancer rate. Am. J. Clin. Nutr., 50, 151-154.

58. Reddy, B.S., and Wynder, E.L. (1977) Metabolic epidemiology of colon cancer. Fecal bile acids and neutral sterols in colon cancer patients and patients with adenomatous polyps. Cancer, 39, 2533-2539.

59. Reddy, B.S., Martin, C.W. and Wynder, E.L. (1977) Fecal bile acids and cholesterol metabolites of patients with ulcerative colitis, a high-risk group for development of colon cancer. Cancer Res., 37, 1697-1701. 
60. Van Faassen, A., Bol, J., van Dokkum, W., Pikaar, N.A., Ockhuizen, T. and Hermus, R.J.J. (1987) Bile acids, neutral steroids, and bacteria in feces as affected by a mixed, a lacto-ovovegetarian, and a vegan diet. Am J. Clin. Nutr., 46, 962-967.

61. De Wit, P.P., Van der Steeg, M. and Van der Gen, A. (1986) Remarkable electrophilic properties of the pentaenol ether system of fecapentaene-12. Tetrahedron letters, 27(51), 6263-6266.

62. Dypbukt, J.M., Edman, C.C., Sundqvist, K., Kakefuda, T., Plummer, S.M., Harris, C.C. and Grafström, R.C. (1989) Reactivity of fecapentaene-12 toward thiols, DNA and these constituents in human fibroblasts. Cancer Res., 49, 6058-6063.

63. Povey, A.C., Plummer, S.M., Grafstrom, R.C. and Harris, C.C. (1990) Genotoxic mechanisms of fecapentaene-12 in human cells. in Pariza, M.W., Aeschbacher, H.W., Felton, J.S. and Sato, S. (Eds.) Mutagens and Carcinogens in the Diet, Wiley-Liss, Chichester, pp. 155-166.

64. Povey, A.C., Schiffman, M., Taffe, B.G. and Harris, C.C. (1991) Laboratory and epidemiologic studies of fecapentaenes. Mutat. Res. 259, 387-397.

65 Povey, A.C., Wilson, V.L., Zweier, J.L., Kuppusamy, P., O'Neill, I.K. and Harris, C.C. (1992) Detection by ${ }^{32}$ P-postlabelling of DNA adducts induced by free radicals and unsaturated aldehydes formed during the aerobic decomposition of fecapentaene12. Carcinogenesis, 13, 395-401.

66. Shioya, M., Wakabayashi, K., Yamashita, K., Nagao,M. and Sugimura, T. (1989) Formation of 8-hydroxydeoxyguanosine in DNA treated with fecapentaene-12 an -14. Mutat. Res. 225, 91-94.

67. Vertegaal, L.B.J., Voogd, C.E., Mohn, G.R. and van der Gen, A. (1989) Further studies on the mutagenic activity of fecapentiene-12 analogues and conclusions about their molecular mode of action. Mutat. Res., 281, 93-98.

68. Hamers, M.H. and Roos, D. (1985) Oxidative stress in human neurtorphilic granulocytes: Host defense and self-defense. In Sies H. (ed.) Oxidative stress, Academic press, London, pp 351-381.

69. Cadet, J., and Berger, M. (1985) Radiation-induced decomposition of the purine bases within DNA and related model compounds. Int. J. Radiat. Biol. 47, 127-143.

70. Schulte-Frohlinde, D., and Von Sonntag, C. (1985) Radiolysis of DNA and model systems in the presence of oxygen. In Sies H. (ed.) Oxidative stress, Academic press, London, pp 11-40.

71. Hutchinson, F. (1985) Chemical changes induced in DNA by ionizing radiation. Prog. Nucleic Acid Res. Mol. Biol. 32, 115-154.

72. Lion, Y., Delmelle, M. and Van de Vorst, A (1976) New method of detecting singlet oxygen production. Nature, 263, 442-443.

73. Blok, J. Luthjens, L.H. and Roos, A.L.M. (1967) The radiosensitivity of bacteriophage DNA in aqueous solution. Radiat. Res., 30,468-482.

74. Lafleur, M.V.M. and Loman, H. (1986) Radiation damage to ФX-174 DNA and biological effects. Radiat. Environ. Biophys. 25, 159-173.

75. Lutgerink, J.T., Retel, J. and Loman H. (1984) Effects of adduct formation on the biological activity of single- and double-stranded Phi-X174 DNA, modified by Nacetyl-2-aminofluorene. Biochem. Biophys. Acta,781, 81-91.

76. Van Maanen, J.M.S., Lafleur, M.V.M., De Ruiter, C., Kootstra, P.R., Vand den Akker, E., Pappie, D., De Vries, J., Retel, J. and Pinedo, H.M. (1988) Effects of the ortho-quinone and catechol of the antitumor drug VP-16-213 on the biological activity of single-stranded and double stranded $\phi X 174$ DNA. Biochem. Pharmacol., 3579-89. 


\section{Summary}

Colorectal cancer appears to be a common disease in Western countries. In search for etiological factors in the development of this disease, diet has been indicated as a relevant factor. Further, much attention has been drawn to the presence of genotoxic compounds in human feces, a matrix to which the bowel epithelium is continuously exposed. Fecapentaenes have been identified as the group of most prominent mutagens in feces of the majority of Western populations. These polyunsaturated compounds are found to originate from bacterial production although their ultimate origin is still unknown. Fecapentaenes appear to possess high in vitro genotoxic potential as determined in various testing systems with prokaryotic as well as mammalian cell types. On the other hand, demonstration of carcinogenic effects in the rodent-colon after application of fecapentaene-12 (FP12), a synthetic representative for all fecapentaenes, by various routes and treatments regimens has repeatedly failed. At other sites than the colon however, FP-12 has been found to induce several types of neoplasia. These genotoxic characteristics of FP-12 and the general occurrence of this class of fecal mutagens in human populations, form the main motive to study fecapentaene excretion in relation to colorectal cancer risk and dietary habits, as described in the first part of this thesis. A second aim of this thesis is to contribute to the elucidation of the genotoxic mechanism of FP-12, which may result in a better understanding of the processes that may be involved in fecapentaene induced cell-transformation.

In order to perform reliable quantification of excreted fecapentaene-levels in feces, a new analytical procedure has been developed based on a rigorous extraction method and a high performance liquid chromatographic separation, which enables quantification of minute amounts of various fecapentaene-analogues (Chapter 2). Application of this extraction procedure was found to result in high fecapentaene recovery; extracts however showed simultaneously low mutagenicity, probably caused by co-extraction of anti-mutagenic compounds. This indicates that determination of fecal mutagenicity is not an accurate tool for indirect measurement of fecapentaene excretion.

This quantitative method has been applied to feces from groups at different risk for developing colorectal cancer. First, a study population has been selected consisting of habitual omnivores and vegetarians (Chapter 3 ). It was found that individuals consuming "low risk" vegetarian diets excrete significantly higher fecal concentrations of fecapentaenes as compared to the reference population with omnivorous dietary habits. Therefore, the initial hypothesis that individuals at low risk excrete low fecapentaene levels appears to be incorrect and has to be rejected. Moreover, as previous research demonstrated that colorectal cancer patients excrete lower fecapentaene concentrations as compared to matched healthy control individuals, it can be suggested that fecal fecapentaene concentrations may relate inversely to intracellular exposure levels, and thereby also to the risk on 
fecapentaene-induced genetic damage.

In chapter 4 an in vitro model has been described to study interactions between FP-12 and various fecal constituents which may be of influence on kinetic properties of fecapentaenes in the large bowel. It has been found that FP-12 may strongly adsorb to fiber material which may explain the positive relation found between fiber consumption and fecapentaene excretion described in Chapter 3. Furthermore, this fiber-potentiated fecapentaene excretion may result in a decrease of cellular fecapentaene-resorption, thus providing a possible explanation for the inverse-relation observed between fecapentaene excretion and colorectal cancer risk as indicated above. Additionally, it was found that high concentrations of bile acids, which are generally linked to increased colorectal cancer risk, increase fecapentaene solubility and thereby bioavailability. Calcium, a dietary factor that was also found to correlate positively with fecapentaene excretion (Chapter 3 ), was found to counteract this solubilizing effect by precipitation with bile acids.

Since most, if not all, carcinomas are known to originate from benign adenomas, patients with adenomatous polyps in colon or rectum were selected for the second study population (Chapter 5). Fecapentaene-excretion patterns have been analysed in feces from this population and compared to those of matched control individuals which after endoscopic examination were found to be free of colorectal neoplasia. However, the results from this study have not shown significant differences in fecapentaene-excretion levels between both groups, therefore providing no evidence to incriminate fecapentaenes as relevant factors during early phases of colorectal carcinogenesis.

In Chapters 6 and 7, the mechanism of fecapentaene genotoxicity has been studied. Two hypotheses have been tested concerning the induction of oxidative DNA-damage by FP-12 as well as alkylating properties of the fecapentaenes. By using electron spin resonance (ESR) spectroscopic techniques, it has been demonstrated that during the aerobic decomposition of FP-12 reactive oxygen species are generated, which in turn are found to induce 2 '-deoxy-7,8-dihydro-8oxoguanosine (8-oxodG), a marker for oxidative DNA-damage. This radical generation appears to be depending on the presence of peroxidative enzymes, whereas the induction of oxidative genetic damage has also been found during spontaneous degradation of FP-12. The generation of singlet oxygen, superoxideanion and hydroxyl radicals has been demonstrated by studying interfering effects of various radical scavengers on the ESR-signal intensities and the induction of 8oxodG. A reaction pathway has been suggested for the generation of these reactive oxygen species, involving the formation of superoxide anion radicals after peroxidation of FP-12, which in turn may result in the formation of hydroxyl radicals and singlet oxygen by combination of spontaneous or enzymatic dismutation of superoxide, and the iron-catalyzed Haber-Weiss reaction.

The mutagenic potential of FP-12 to Salmonella typhimurium has been found to be partially reduced by addition of oxygen radical scavengers, furthermore confirming the involvement of oxidative DNA-damage in fecapentaenemutagenicity. On the other hand, the inactivation of bacteriophage $\phi X-174$ DNA appears to be only marginally influenced by radical scavenging, indicating a second mechanism for genotoxicity. Moreover, using this DNA inactivation test, it has been found that enhanced radical generation by enzymatic peroxidation of 
FP-12 results in decreased DNA inactivation. These data may indicate that oxygen radical generation rate is not an important factor in FP-12 induced DNA-damage. Further, calculation of the contribution of 8-oxodG in $\phi X-174$ DNA inactivation indicates that the induction of this type of oxidative DNA damage may only contribute to a minor extent to fecapentaene genotoxicity. Finally, preliminary results of ${ }^{32} \mathrm{P}$-postlabelling studies have shown additional spots of putative DNAadducts of fecapentaene or fecapentaene-fragments on autoradiography, after incubation of FP-12 with single-stranded rat liver DNA. The induction of these additional spots appears to be substantially reduced by enzymatic peroxidation of FP-12. Based on this observation and the above mentioned reduced inactivation of $\phi X-174$ DNA after peroxidation, it may be suggested that fecapentaenes and/or fecapentaene-derived reactive alkyl-fragments are converted to non-reactive endproducts by rapid enzymatic peroxidation. This may furthermore result in lower DNA-alkylation levels as well as reduced induction of biological effects.

It is concluded that in view of their potency to induce a variety of genotoxic effects in vitro as well as their ability to interact with colon epithelial DNA and to induce neoplasia in various animal tissues, fecapentaenes should be considered as potential colon-carcinogens. In order to estimate the risk of fecapentaeneexposure and their actual role in colorectal carcinogenesis, it seems essential to investigate the induction of genetic modifications in more detail after fecapentaene-exposure of human colon epithelium under normal physiological conditions. 


\section{Samenvatting}

Dikke-darmkanker is een veel voorkomende ziekte in Westerse landen. Uit het onderzoek naar de belangrijkste oorzaken van het ontstaan en de ontwikkeling van deze aandoening is naar voren gekomen dat het dieet van grote betekenis is. Daarnaast is veel aandacht uitgegaan naar het vóórkomen van genotoxische verbindingen in de ontlasting, waaraan de darm voortdurend is blootgesteld. Fecapentaenen zijn hierbij geidentificeerd als de belangrijkste groep van verbindingen die tevens aangetroffen wordt in het merendeel van Westerse bevolkingsgroepen. Deze meervoudig onverzadigde fecapentaenen blijken te worden gesynthetiseerd door algemeen voorkomende darmbacteriën, waarbij de oorsprong van de precusormoleculen nog niet is opgehelderd. Daarnaast bezitten deze faecale verbindingen een extreem hoge mutagene capaciteit zoals blijkt uit verschillende in vitro genotoxiciteitstesten met zowel prokaryotische- als zoogdiercellen. Daar staat tegenover dat geen duidelijke kankerverwekkende eigenschappen zijn aangetoond in de darm van verschillende proefdieren na het toedienen van synthetisch fecapentaeen-12 (FP-12), een representatieve verbinding voor alle fecapentaenen. Voor andere doelwitorganen dan de darm zijn echter wel carcinogene eigenschappen van FP-12 beschreven. Deze genotoxische karakteristieken van FP-12 en het vóórkomen van deze klasse van verbindingen in het merendeel van humane bevolkingsgroepen, vormen de belangrijkste redenen om fecapentaenen-excretie te bestuderen in relatie tot het risico op dikkedarmkanker en eetgedrag, zoals beschreven in het eerste deel van dit proefschrift. Een tweede doelstelling van dit proefschrift is een bijdrage te leveren aan de opheldering van het genotoxiciteitsmechanisme van FP-12, hetgeen kan bijdragen aan een beter inzicht in de processen die mogelijk ten grondslag liggen aan fecapentaeen-geïnduceerde celtransformatie.

Om op een betrouwbare en reproduceerbare wijze de uitscheiding van fecapentaenen te kunnen kwantificeren in faeces van relatief grote onderzoekspopulaties, is een nieuwe analyse ontwikkeld, gebaseerd op een rigoureuze extractieprocedure en een hoge druk vloeistof-chromatografische scheiding van verschillende fecapentaeen-analoga (Hoofdstuk 2). Toepassing van deze methodiek blijkt te resulteren in een verbeterde extractie-opbrengst, wat tevens gepaard gaat met een relatief lage fecale mutageniteit. Waarschijnlijk wordt dit veroorzaakt door de co-extractie van verschillende anti-mutagene stoffen die eveneens aanwezig zijn in de ontlasting. Dit geeft aan dat de bepaling van faecale mutageniteit geen goede parameter is voor het indirect kwantificeren van fecapentaenen-excretie.

Deze nieuwe procedure is toegepast op faeces van individuen met een verschillende kans op het ontwikken van dikke-darmkanker. Als eerste is een studiepopulatie geselecteerd bestaande uit vegetariërs en omnivoren (Hoofdstuk 3). Uit deze fecapentaenen-analyses blijkt dat mensen met een "laag-risico", vegetarisch dieet, faeces uitscheiden met significant hogere fecapentaenen- 
concentraties in vergelijking met de referentie populatie bestaande uit mensen met omnivore eetgewoonten. Dit geeft aan dat de oorspronkelijke hypothese, waarbij er vanuit wordt gegaan dat mensen met een laag risico ook lagere fecapentaenenconcentraties uitscheiden, onjuist is en verworpen moet worden. Omdat uit eerder onderzoek is gebleken dat darmkankerpatiënten lagere fecapentaenenconcentraties uitscheiden in vergelijking met controle personen, kan verondersteld worden dat faecale fecapentaenen-concentraties omgekeerd evenredig zijn met cellulaire blootstellingsconcentraties, en het daarmee samenhangende risico op fecapentaeen-geïnduceerde genetische schade.

In hoofdstuk 4 wordt een in vitro model beschreven om interacties te bestuderen tussen FP-12 en verschillende faecale componenten die de kinetiek van de fecapentaenen in de darm kunnen beïnvloeden. Uit deze studies is gebleken dat FP-12 in sterke mate kan adsorberen aan vezelmateriaal waardoor de positieve relatie die gevonden is tussen vezelconsumptie en fecapentaenen-excretie (Hoofdstuk 3) verklaard zou kunnen worden. Voorts kan deze door vezel gestimuleerde fecapentaenen-excretie leiden tot een afname in cellulaire fecapentaeen-resobtie, hetgeen tevens een mogelijke verklaring biedt voor de omgekeerde relatie die gevonden is tussen fecapentaenen-excretie en risico op darmkanker zoals hierboven is aangegeven. Verder is gebleken dat hoge concentraties galzuren, die over het algemeen in verband worden gebracht met een verhoogd risico op darmkanker, kunnen bijdragen aan een verhoogde oplosbaarheid van fecapentaenen en de daarmee samenhangende biologische beschikbaarheid. Calcium, een van de voedingsfactoren die eveneens een positieve correlatie vertoont met fecapentaenen-excretie, kan dit oplossend effect verminderen door vorming van een neerslag met deze galzuren.

Aangezien de meeste darmcarcinomen ontstaan uit goedaardige adenomen, zijn voor de tweede studiepopulatie patiënten geselecteerd met adenomateuze poliepen in het colon of rectum. Fecapentaenen-excretiepatronen zijn geanalyseerd in de ontlasting van deze personen en vergeleken met die van een bijpassende controle groep, bestaande uit mensen waarbij tijdens endoscopisch onderzoek is vastgesteld dat zij geen tumoren hebben in de darm. In deze studie is echter geen verschil aangetoond tussen fecpaentaenen-excretie in beide groepen, waardoor er geen aanleiding is te veronderstellen dat fecapentaenen betrokken zijn als initiërende verbindingen gedurende de vroege ontwikkelingsfasen van kanker in de dikke darm.

In de hoofdstukken 6 en 7 worden de studies naar het genotoxiciteitsmechanisme van FP-12 beschreven. Hierbij zijn twee hypothesen getoetst, betreffende de inductie van oxidatieve DNA-schade door FP-12 en de alkylerende eigenschappen van de fecapentaenen. Met behulp van electron spin resonantie spectroscopie (ESR) is aangetoond dat reactieve vormen van zuurstof kunnen ontstaan tijdens het aerobe verval van FP-12. Deze zuurstof radicalen zijn op hun beurt in staat om 2'-deoxy-7,8-dihydro-8-oxoguanosine (8-oxodG) te induceren, een specifieke vorm van oxidatieve DNA-schade. Voor de detectie van deze radicalen blijkt de aanwezigheid van peroxidatieve enzymen noodzakelijk, terwijl 8-oxodG ook wordt geinduceerd tijdens de spontane degradatie van FP-12. Onderzoek naar de interfererende effecten van radicaal scavengers op de ESRsignaal intensiteiten en de inductie van 8 -oxodG heeft aangetoond dat zowel 
singlet zuurstof als superoxide anion en hydroxyl radicalen betrokken zijn bij de inductie van oxidatieve DNA-schade. Een reactieschema is opgesteld voor de vorming van deze reactieve zuurstofmoleculen, uitgaande van de vorming van superoxide anion radicalen na de peroxidatie van FP-12, wat vervolgens resulteert in de vorming van hydroxyl radicalen en singlet zuurstof door de combinatie van spontane of enzymatische dismutatie van superoxide en de ijzer-gekataliseerde Haber-Weiss reactie.

De mutageniteit van FP-12 in Salmonella typhimurium kan gedeeltelijk worden gereduceerd door toevoeging van radicaal scavengers, hetgeen de betrokkenheid van zuurstof radicalen in de mutageniteit van de fecapentaenen verder bevestigt. Daar staat tegenover dat de inactivatie van bacteriofaag $\phi X-174$ DNA slechts marginaal wordt beinvloed door het wegvangen van radicalen. Dit geeft aan dat waarschijnlijk een tweede mechanisme een rol speelt bij de inductie van genetische schade door FP-12. Daar komt bij dat in dezelfde DNAinactiveringstest het stimuleren van de zuurstofradicaalvorming door enzymatische peroxidatie van FP-12 resulteert in een verminderde DNAinactivatie. Deze gegevens tonen aan dat het tempo van radicaalvorming blijkbaar geen belangrijke factor is in FP-12-geinduceerde DNA-schade. Verder geeft berekening van de bijdrage van 8-oxodG in de inactivering van $\phi X-174$ DNA aan dat de inductie van deze vorm van oxidatieve DNA schade slechts in geringe mate de genotoxiciteit van FP-12 verklaart.

De eerste ${ }^{32} \mathrm{P}$-postlabellingsstudies na incubatie van enkel strengs rattelever DNA met FP-12 geven een aantal extra spots van mogelijke FP-12 of FP-12-fragment adducten aan DNA. De vorming van deze extra spots blijkt grotendeels te reduceren door toevoeging van peroxidases aan het incubatie mengsel. Deze waarneming in combinatie met de bovengenoemde afname in $\phi X-174$ DNAinactivatie na toevoeging van peroxidases suggereert dat FP-12 of van FP-12 afgeleide reactieve alkyl-fragmenten omgezet worden tot niet reactieve eindproducten door snelle enzymatische peroxidatie. Dit kan verder resulteren in verminderde DNA-alkylerings niveaus en inductie van biologische effecten.

Gebaseerd op de potentie van FP-12 om een breed scala van genotoxische effecten te induceren in in vitro testsystemen alsmede de mogelijkheid om interacties aan te gaan met colonepitheel-DNA en tumoren te induceren in verschillende proefdier-organen, is geconcludeerd dat fecapentaenen beschouwd moeten worden als mogelijke darmcarcinogenen. Om een risico-evaluatie te maken voor blootstelling aan fecapentaenen en hun exacte betrokkenheid te bepalen in de colon-carcinogenese, lijkt het noodzakelijk om de inductie van genetische schade meer in detail te bestuderen na blootstelling van humaan colonepitheel onder normale fysiologische omstandigheden. 


\section{Dankwoord}

Dit proefschrift is tot stand gekomen dankzij de assistentie, adviezen en medewerking van een groot aantal personen. Daarom wil ik op deze plaats iedereen bedanken die op enigerlei wijze een bijdrage heeft geleverd aan het fecapentaenen-onderzoek of het schrijven van dit proefschrift. Enkelen wil ik graag met naam vernoemen:

Prof. dr. J.C.S. Kleinjans, promotor en directe begeleider van het onderzoek. Beste Jos, het kan gerust gesteld worden dat met name door de stimulering en motivering van jouw kant, meerdere facetten van het fecapentaenen-vraagstuk zijn belicht, wat dit onderzoek voor mij extra interessant en leerzaam heeft gemaakt. Verder heb ik me keer op keer verbaasd over het tempo en de grondigheid waarmee je mijn concept-teksten wist te becommentariëren, om zoals jezelf zei, "de vaart erin te houden".

Mijn promotor prof. dr. F. ten Hoor, voor de prettige manier van samenwerking en kritische kanttekeningen bij de diverse manuscripten.

Ing. Ben van Agen, mijn kamergenoot. Je hebt me prima wegwijs gemaakt in het isoleren van DNA en geassisteerd bij het kweken van cellen wat noodzakelijk was voor het tot stand komen van hoofdstuk 7. Daarnaast hebben we de laatste jaren van alles en nog wat op onze kamer besproken en menige filosofische boom opgezet.

Een bijzonder woord van dank gaat uit naar ing. Daniëlle Pachen, die de HPLCanalyse van oxidatieve DNA-schade heeft opgezet en uitgevoerd. Daarna ben je gedurende enkele maanden onafgebroken bezig geweest met de "minder frisse" verwerking en bewerkelijke chemische analyse van een groot aantal ontlastingsmonsters uit het patiënt-controle onderzoek, hetgeen werkelijk een opgave was. Dit brengt mij tevens bij dr. Cor Baeten en dr. Leopold Engels van het AZM en het Maasland Ziekenhuis te Sittard, die hun patiënten gevraagd hebben medewerking te verlenen aan het fecapentaenen-onderzoek, en tevens de endoscopiën hebben verricht.

Vervolgens wil ik Marlou van lersel bedanken voor haar inzet tijdens haar stage periode. Vooral na de verhuizing van het AZM naar de nieuwe locatie was het verzamelen van ontlasting een tijdrovende bezigheid. Toch heb je de moed niet opgegeven wanneer keer op keer bleek dat de dozen weer even onaangeroerd mee terug konden. Verder zijn de gegevens voor hoofdstuk 4 grotendeels jouw werk.

Drs. Diny van Faassen van de vakgroep Urologie en ir. Sandra Bausch-Goldbohm van TNO-Voeding te Zeist wil ik bedanken voor het beschikbaarstellen van de faeces-monsters en voedingsgegevens voor het onderzoek naar fecapentaenenuitscheiding bij vegetariers en omnivoren. 
Dr. J.M.S. van Maanen voor zijn assistentie bij het uitvoeren van de ESR experimenten op het lab van de vakgroep Oncologie aan de VU te Amsterdam. Jan, zonder jouw geroutineerde "Fingerspitzen-gefühl" waren we nooit zover gekomen. Bovendien bleken deze enkele weken in Amsterdam behalve hoogst productief ook erg amusant.

De DNA-inactiverings experimenten zijn uitgevoerd in samenwerking met de vakgroep Antropogenetica aan de VU te Amsterdam, waar ik met raad en daad werd bijgestaan door dr. Vincent Lafleur, Joke Westmijze en Erik van den Akker. Het was een waar genoegen om met jullie samen te werken.

Ing. Lou Maas voor het uitvoeren van de postlabelings experimenten beschreven in hoofdstuk 7, en dr. Jan Dallinga voor het uitvoeren van de massa spectrometrische analyses.

Hoewel een groot aantal personen die ontlasting hebben opgevangen voor een fecapentaenen analyse bij mij niet persoonlijk bekend is, ben ik toch iedereen die als donor is opgetreden mijn erkentelijkheid verschuldigd. Al is het niet pijnlijk, voor velen is een buisje bloed geven toch minder bezwaarlijk dan op een emmertje te moeten plaatsnemen.

Daarnaast wil ik alle leden van de vakgroep Gezonheidsrisico analyse en Toxicologie evenals de vakgroep Humane biologie bedanken voor de prettige werksfeer waarin ik dit onderzoek heb kunnen uitvoeren.

Mijn beide paranimfen Marc Bookelman en Erik van Binsbergen zijn zorgvuldig geselecteerd op de overtuigingskracht die werd aangewend om mij duidelijk te maken dat er nog meer in het leven is dan FP's, HPLC, ECD en ESR.

Mijn ouders die me in de gelegenheid hebben gesteld een academische opleiding te volgen en steeds belangstellend, zoals vele andere familie leden, mijn vorderingen hebben gevolgd.

Tenslotte mevrouw G.J.N.M. de Kok-Donkers, voor haar computter-assistentie en administratieve ondersteuning in de laatste weken; en Trudy voor je eindeloze geduld met mij. Marloes, jouw eerste lachjes in deze drukke periode waren voor mij de beste ontspanning. 


\section{List of co-authors}

Van Iersel, M.L.P.S.,

Kleinjans, J.C.S.,

Van Maanen, J.M.S.,

Maas, L.M.,

Pachen, D.,

Department of Health Risk Analysis and Toxicology, University of Limburg, P.O. Box 616, 6200 MD Maastricht, The Netherlands.

Ten Hoor, F.,

Department of Human Biology, University of Limburg, P.O. Box 616, 6200 MD Maastricht, The Netherlands.

Van Faassen, A.,

Department of Urology, Academic Hospital, P.O. Box 5800, 6202 AZ Maastricht, The Netherlands.

Bausch-Goldbohm, R.A.,

TNO Toxicology and Nutrition Institute, P.O. Box 360, 3700 AJ Zeist. The Netherlands.

Baeten, C.G.M.I.,

Department of surgery, Academic Hospital Maastricht, PO Box 5800, 6202 AZ Maastricht, The Netherlands.

Engels, L.G.J.B.,

Department of Gastroenterology, Maasland Hospital Sittard, Walramstraal 23, 6135 BK Sittard, The Netherlands.

Lankelma, J.,

Department of Oncology, Free University Hospital, De Boelelaan 1117, 1081 HV Amsterdam, The Netherlands.

Lafleur, M.V.M.,

Westmijze, E.J.,

Department of Antropogenics, Free University, van der Boechorststraat 7, 1081

BT Amsterdam, The Netherlands. 


\section{List of publications}

\section{Full papers}

- Gorris, L.G., de Kok, T.M., Kroon, B.M., van der Drift, C. and Vogels, G.D. (1988) Relationship between methanogenic cofactor content and maxiumu specific methanogenic activity of anaerobic granular sludges. Appl. Environ. Microbiol. 54, 1126-1130.

- De Kok, T.M.C.M. and Kleinjans J.C.S. (1990) Fecapentaenen, mutagene bacteriële producten in humane faeces. Giftig, 5, 13-15.

De Kok, T.M.C.M., Ten Hoor, F. and Kleinjans, J.C.S. (1991) Identification and quantitative distribution of eight analogues of naturally occurring fecapentaenes in human feces by high performance liquid chromatography. Carcinogenesis 12, 199-205.

- De Kok, T.M.C.M., Van Faassen, A., Bausch-Goldbohm, R.A., Ten Hoor, F. and Kleinjans, J.C.S. (1992) Fecapentaene excretion and fecal mutagenicity in relation to nutrient intake and fecal parameters in humans on omnivorous and vegetarian diets. Cancer Lett., 62, 11-21.

- De Kok, T.M.C.M., Van Maanen, J.M.S., Lankelma, J., Ten Hoor, F. and Kleinjans, J.C.S. (1992) Electron spin resonance spectroscopy of oxygen radicals generated by synthetic fecapentaene-12 and reduction of fecapentaene mutagenicity to Salmonella typhimurium by hydroxyl radical scavenging. Carcinogenesis, 13, 1249-1255.

- De Kok, T.M.C.M., Levels, P.J., Van Faassen, A., Hazen, M., Ten Hoor, F. and Kleinjans, J.C.S. (1992) Chromatographic methods for the analysis of toxicants in faeces. J. Chromatogr., 580, 135-159.

- De Kok, T.M.C.M., Van Iersel, M.L.P.S., Ten Hoor, F. and Kleinjans, J.C.S. (1992) In vitro study on the effects of fecal composition on fecapentaene kinetics in the large bowel. Mutat. Res., Submitted.

De Kok, T.M.C.M., Pachen, D., Baeten, C.G.M.I., Engels, L.G.J.B., ten Hoor, F. and Kleinjans, J.C.S. (1992) Case-control study on fecapentaene excretion and adenomatous polyps in colon and rectum. J. Natl. Cancer Inst., Submitted.

\section{Abstracts}

- De Kok, T.M.C.M., Ten Hoor F. and Kleinjans J.C.S. (1990) Occurrence of different forms of fecapetnaenes in a normal human population. Pharmac. Weekbl. Sci. Ed., 12, B5.

- De Kok, T.M.C.M., Ten Hoor F. and Kleinjans J.C.S. (1990) Occurrence and mutagenic activity of different fecapentaene analogues in human fecal extracts. In: 20 th EEMS meeting, book of abstracts, York, England, p2.

De Kok, T.M.C.M., Van Faassen, A., Bausch-Goldbohm, R.A., Ten Hoor, F. and Kleinjans, J.C.S. (1991) Excretion of different fecapentaene analogues and fecal mutagenicity in relation to dietary habits of vegetarians and omnivores. In: The 1991 Eurotox congress, book of abstracts, Maastricht The Netherlands, p 305.

- De Kok, T.M.C.M., Van Maanen, J.M.S., Lankelma, J., Ten Hoor, F. and Kleinjans, J.C.S. (1992) Generation of oxygen radicals by fecapentaene- 12 and their involvement in fecapentaene-mutagenicity to Salmonella. Pharmac. Weekbl. Sci. Ed., in press.

- De Kok, T.M.C.M., Van Faassen, A., Bausch-Goldbohm, R.A., Ten Hoor, F. and Kleinjans, J.C.S. (1992) Dietary effects on fecapentaene-excretion. Am. J. Clin. Nutr. in press. 


\section{Curriculum vitae}

Theodorus Martinus Comelis Maria (Theo) de Kok werd geboren op 21 februari 1963 te Goirle. In 1981 behaalde hij het atheneum-b diploma an het Theresia lyceum te Tilburg. Daarna startte hij met de studie biologie aan de Katholieke Universiteit te Nijmegen. In 1984 behaalde hij het kandidaatsdiploma (B1g). De docteraal fase werd afgesloten in 1988 en bestond uit het hoofdvak Microbiologie (prof. dr. G.D. Vogels; dr. L. Gorris) en de bijvakken Algemene botanie (prof. Linskens; dr P. van der Kroon [Zoologie]) en Toxicologie (dr J. CopiusPeereboom; ir. C.T.A. Evelo). Tevens behaalde hij in deze periode eerste graads lesbevoegdheid Biologie, en is na het behalen van zijn doctoraal examen enkele maanden werkzaam geweest als docent biologie aan het Jeroen Bosch College te 's Hertogenbosch. Vanaf november 1988 is hij als assistent in opleiding werkzaam geweest aan de Rijksuniversiteit Limburg te Maastricht bij de vakgroep Humane Biologie (Biologische Gezondheidkunde [i.o.]) later Gezondheidsrisico Analyse en Toxicologie (prof. dr. F. ten Hoor, prof. dr. J.C.S. Kleinjans) alwaar het onderzoek zoals beschreven is in dit proefschrift werd uitgevoerd. Vanaf oktober 1992 is hij werkzaam als cursusteamleider bij de productgroep Natuurwetenschappen aan de Open universiteit te Heerlen. 
